JULIANA LÍVI ANTONIASSI

A DIFRAÇÃO DE RAIOS X COM O MÉTODO DE RIETVELD APLICADA A BAUXITAS DE PORTO TROMBETAS, PA

São Paulo 
JULIANA LÍVI ANTONIASSI

\title{
A DIFRAÇÃO DE RAIOS X COM O MÉTODO DE RIETVELD APLICADA A BAUXITAS DE PORTO TROMBETAS, PA
}

\author{
Dissertação apresentada à Escola \\ Politécnica da Universidade de São \\ Paulo para obtenção de título de \\ Mestre em Ciências
}

São Paulo 
JULIANA LÍVI ANTONIASSI

\title{
A DIFRAÇÃO DE RAIOS X COM O MÉTODO DE RIETVELD APLICADA A BAUXITAS DE PORTO TROMBETAS, PA
}

\author{
Dissertação apresentada à Escola \\ Politécnica da Universidade de São \\ Paulo para obtenção de título de \\ Mestre em Ciências \\ Área de Concentração: \\ Engenharia Mineral \\ Orientador: \\ Prof. Dr. Henrique Kahn
}


Este exemplar foi revisado e alterado em relação à versão original, sob responsabilidade única do autor e com a anuência de seu orientador.

São Paulo, 05 de abril de 2010.

Assinatura do autor

Assinatura do orientador

\section{FICHA CATALOGRÁFICA}

Antoniassi, Juliana Lívi

A difração de raios $X$ com o método de Rietveld aplicada a bauxitas de Porto Trombetas, PA / J.L. Antoniassi. -- ed.rev. -São Paulo, 2010.

$111 \mathrm{p}$.

Dissertação (Mestrado) - Escola Politécnica da Universidade de São Paulo. Departamento de Engenharia de Minas e de Petróleo.

1. Caracterização tecnológica de minérios 2. Bauxita 3. Difração por raios X (Metodologia; Análise quantitativa) I. Universi dade de São Paulo. Escola Politécnica. Departamento de Engenharia de Minas e de Petróleo II. t. 


\section{AGRADECIMENTOS}

À empresa Mineração Rio do Norte (MRN), por possibilitar a realização deste estudo por meio do fornecimento das amostras e da execução de parte das análises químicas aqui apresentadas.

À Profa. Dra. Lilia Mascarenhas Sant'Agostino, pela excelente orientação, dedicação e fundamental participação no desenvolvimento do projeto.

Ao Prof. Dr. Henrique Kahn, coordenador do LCT - Laboratório de Caracterização Tecnológica, onde foi executado todo este trabalho, pelo incentivo e colaboração.

Aos geólogos Luciano Gobbo, Liz D'Agontinho, Mariane Brumatti, Thiago Piacentini e Daniel Uliana pelas contribuições e companheirismo, assim como à engenheira Carina Ulsen pelas sugestões dadas à finalização da dissertação.

Ao Depto. de Engenharia de Minas da Universidade Federal de Ouro Preto (UFOP-MG) e a Geraldo Magela, pela execução das análises de Mössbauer.

À bibliotecária Maria Cristina Bonesio pela ajuda e boa vontade.

À Daniela Uli, pela amizade e apoio incondicional; e a Fabio Brentan, por ter me acompanhado em cada momento.

E finalmente, agradeço aos meus pais, Marcos e Alice, pela confiança e carinho. Dedico este trabalho a vocês. 


\section{SUMÁRIO}

pag.

Lista de ilustrações............................................................................................

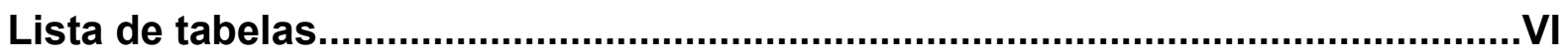

Lista de fotomicrografias.............................................................................. VII

Lista de abreviaturas e siglas................................................................... VIII

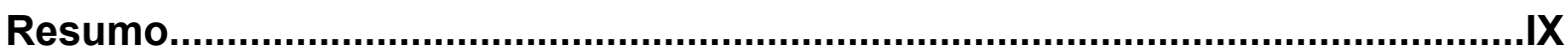

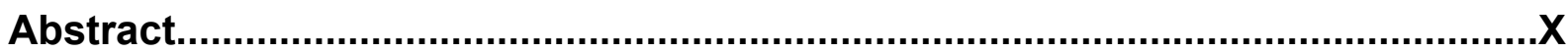

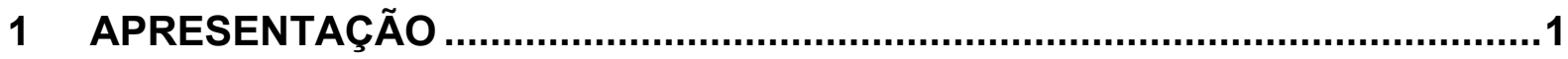

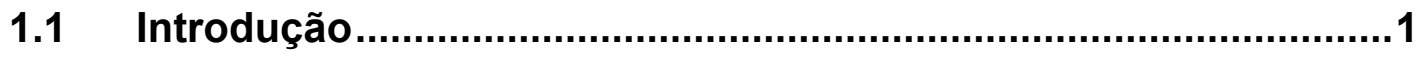

1.2 Objetivos .................................................................................

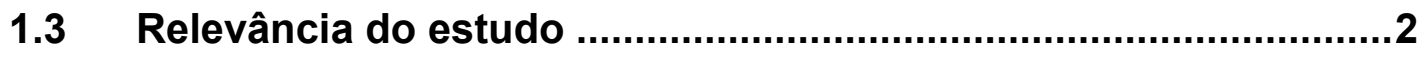

2 REVISÃO BIBLIOGRÁFICA................................................................

2.1 Aspectos geológicos dos depósitos de bauxita ...........................

2.1.1 Formações lateríticas .................................................

2.1.2 Depósitos de bauxitas lateríticas......................................... 4

2.1.3 Bauxita de Porto Trombetas, PA ......................................

2.2 Explotação de bauxita ...........................................................11

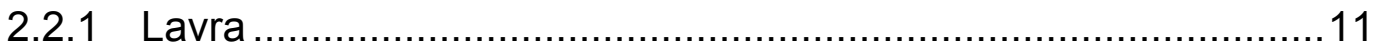

2.2.2 Beneficiamento mineral..................................................11

2.2.3 Processo hidrometalúrgico - processo Bayer ....................... 14

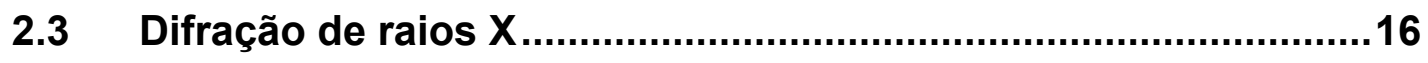

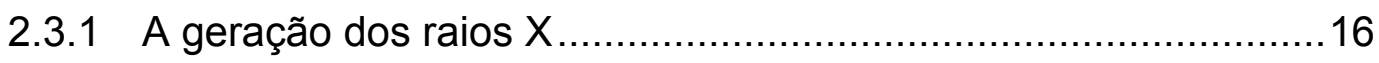

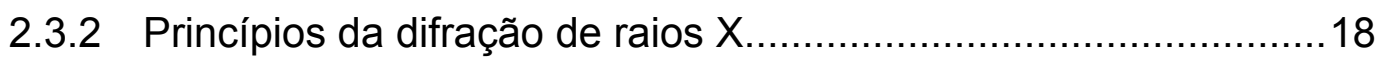

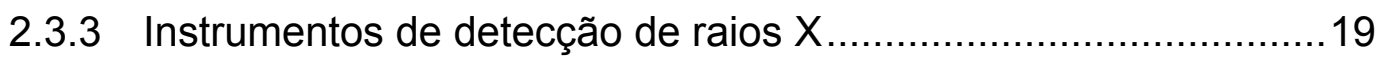


2.3.4 Fatores interferentes na intensidade, posição e perfil de picos ...25

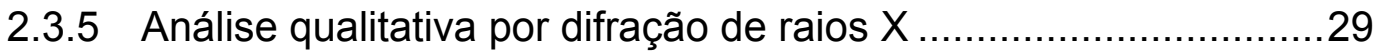

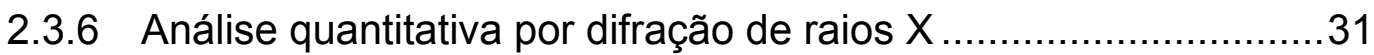

2.3.6.1 O método de Rietveld .................................................31

2.3.6.2 O método de Rietveld aplicado a bauxitas .........................35

\subsection{Técnicas complementares ao trabalho ....................................36}

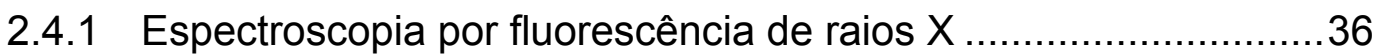

2.4.2 Método de estimativa mineral apoiado em análises químicas .....37

2.4.3 Microscopia eletrônica de varredura ....................................39

2.4.4 Método estatístico de análise por agrupamento.....................40

2.4.5 Espectroscopia Mössbauer ........................................42

3 MATERIAIS E MÉTODOS ......................................................................45

3.1 Amostras estudadas ...........................................................45

3.2 Procedimento experimental .................................................46

3.2.1 Difratometria de raios $X$ para reconhecimento das amostras......46

3.2.2 Análise por agrupamento ...............................................48

3.2.3 Caracterização mineralógica ................................................49

3.2.4 Difração de raios X com o método de Rietveld .........................50

3.2.5 Análises por espectroscopia Mössbauer.................................55

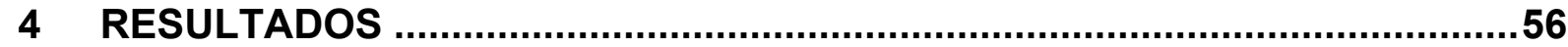

$4.1 \quad$ Mineralogia das bauxitas ........................................................56

4.1.1 Identificação das espécies minerais....................................56

4.1.2 Formas de ocorrência da gibbsita .......................................57

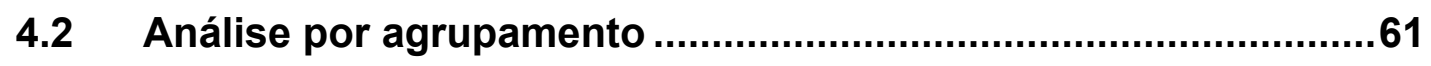

4.3 Determinação das proporções minerais ................................68

4.3.1 Caracterização mineralógica ............................................68

4.3.1.1 Classificação granulométrica ...................................68 
4.3.1.2 Separação em líquido denso .70

4.3.1.3 Estimativa da composição mineralógica.............................73

4.3.2 Espectroscopia Mössbauer ............................................. 75

4.3.3 Difração de raios X com método de Rietveld .........................77

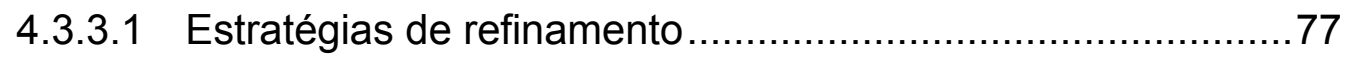

4.3.3.2 Quantificações por DRX-Rietveld ............................... 82

5 DISCUSSÃO DE RESULTADOS ........................................................ 86

5.1 Comparação entre os métodos de quantificação mineral ...........86

5.2 Comparação entre DRX-Rieveld e análises químicas .................89

6 CONCLUSÕES ...................................................................................91

6.1 Sugestões de trabalhos complementares................................93

REFERÊNCIAS BIBLIOGRÁFICAS.........................................................95

APÊNDICE A - Ajustes dos espectros obtidos por espectroscopia Mössbauer APÊNDICE B - Ajustes dos refinamentos pelo método de Rietveld 


\section{LISTA DE ILUSTRAÇÕES}

Figura 1 - Localização das grandes regiões de depósitos de bauxita no Brasil (HERNALSTEENS; LAPA, 1988)

Figura 2 - Mapa de localização do rio Trombetas, PA - Brasil (TROMBETAS, 2009) 7

Figura 3 - Mapa geológico regional ao milionésimo, onde se localizam os platôs referentes ao depósito de bauxitas de Porto Trombetas, PA (modificado de CPRM, 2004).

Figura 4 - Seção geológica-tipo (A) e coluna estratigráfica (B) dos depósitos de bauxita de Porto Trombetas, Pará. (C) Minerais principais e minerais pesados dos horizontes do perfil de alteração. (HERNALSTEENS; LAPA, 1988, apud BIONDI, 2003).

Figura 5 - Procedimento em tiras na lavra de bauxitas (ABAL, 2009).

Figura 6 - Britagem no beneficiamento de bauxita da MRN (Foto: Henrique Kahn).12

Figura 7 - Atrição no beneficiamento de bauxita da MRN (Foto: Henrique Kahn) ....12

Figura 8 - Peneiramento no beneficiamento de bauxita da MRN (Foto: Henrique Kahn). 13

Figura 9 - Secagem (ciclones) no beneficiamento de bauxita da MRN (Foto: Henrique Kahn).

Figura 10 - Pilha de produto beneficiado de bauxita da MRN (Foto: Henrique Kahn)

Figura 11 - Barragens de finos da MRN (Foto: Henrique Kahn). .14

Figura 12 - Corte longitudinal de um tudo de raios X tradicional (adaptado de Cullity, 1978) 16

Figura 13 - A produção de raios X a nível atômico (BLEICHER; SASAKI, 2000).....17

Figura 14 - Espectros de raios $X$ contínuo e característico para o molibdênio a $35 \mathrm{kV}$ $\left(\mathrm{A}\right.$ e B). À direita é detalhado o dubleto $\mathrm{Ka}_{1}$ e $\mathrm{Ka}_{2}$ referente à linha $\mathrm{Ka}$ (adaptado de Cullity, 1978)

Figura 15 - llustração do fenômeno de difração de raios X - Lei de Bragg 19

Figura 16 - Câmara de pó - Debye-Scherrer (CULLITY, 1978) . 20 
Figura 17 - Resultado da análise de difração de raios $X$ obtido pela câmara Debye-

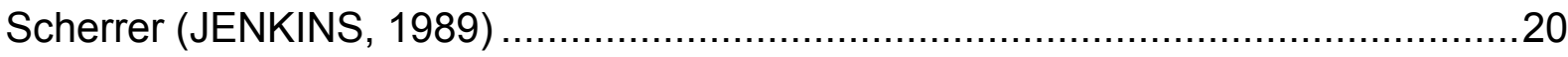

Figura 18 - Geometria Bragg-Brentano (adaptado de Jenkins, 1989) ...................21

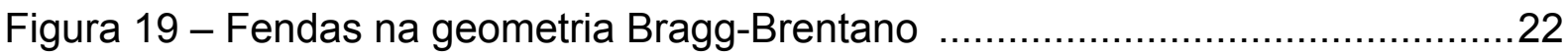

Figura 20 - Configuração $\theta-2 \theta$ de um difratômetro de raios $X$ - detector pontual ....23

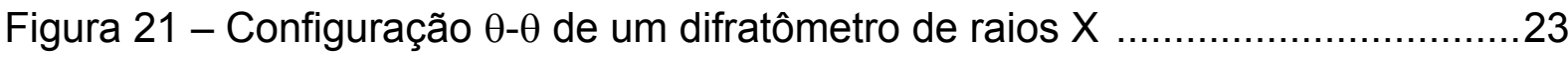

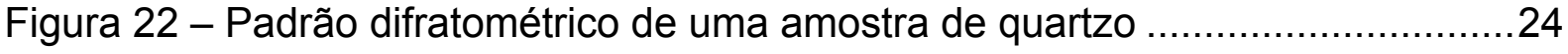

Figura 23 - Sistemas automáticos de identificação de fases (software High Score Plus da PANalytical), onde prováveis fichas de compostos são propostas. 30

Figura 24 - Características de difratogramas refinados em função de fatores físicos, instrumentais ou de preparação de amostra, segundo McCusker et al. (1999) ........33

Figura 25 - Análise por agrupamento hierárquico (TAN; STEINBACH; KUMAR, 2005)

Figura 26 - Espectro de um composto de ferro apresentando um sexteto. São apresentados o deslocamento isométrico $(\delta)$ e o desdobramento quadrupolar $(\varepsilon)$ (WERTHEIEM, 1964)

Figura 27 - Procedimento experimental adotado

Figura 28 - Difratogramas comparativos das amostras A, B e C utilizadas nos testes de definição de condições de prensagem ( $g b=$ gibbsita; $c=$ caulinita; $h=$ hematita).....51

Figura 29 - Difratogramas comparativos para diferentes condições de prensagem hidráulica $(1,5,3,10$ toneladas). Detalhe para picos $(002)$ e (110) da gibbsita amostra A

Figura 30 - Variações na intensidade dos picos (002) da gibbsita (I) e (001) da caulinita (II) para diferentes tempos de prensagem hidráulica (amostra A contém caulinita insuficiente para a medição de seus picos). 52

Figura 31 - Sobreposições dos difratogramas das 60 amostras em estudo. Semelhança mineralógica observada pela similaridade da posição e intensidades relativas dos picos das amostras ( $g b=$ gibbsita; $c=$ caulinita; $h=$ hematita). .56 
Figura 32 - Dendograma da análise por agrupamento das amostras da pesquisa mineral $(P)$, segundo um cut-off de 85 .

Figura 33 - Diagrama de análise do componente principal (três primeiros Eigenvalues) das amostras da pesquisa mineral $(P)$; destaque para as amostras selecionadas como representantes da variabilidade mineralógica.

Figura 34 - Comparação entre difratogramas de amostras representantes de cada grupo originado para a pesquisa mineral ( $g b=$ gibbsita; $c=$ caulinita; $h=$ hematita; a=anatásio)

Figura 35 - Diferenciação entre agrupamentos de amostras da pesquisa mineral $(P)$ em função de suas características químicas.

Figura 36 - Dendograma da análise por agrupamento dos produtos de beneficiamento $(U)$, segundo um cut-off de 40

Figura 37 - Diagrama de análise do componente principal (três primeiros Eigenvalues) das amostras dos produtos de beneficiamento (U); destaque para as amostras selecionadas como representantes da variabilidade mineralógica..... .66

Figura 38 - Comparação de difratogramas representativos de cada grupo originado dentre as amostras de produto de beneficiamento ( $g b=$ gibbsita; $c=$ caulinita; $\mathrm{h}=$ hematita); nota-se a extrema semelhança entre eles .66

Figura 39 - Diagramas de correlação de teores para produtos do beneficiamento ..67 Figura 40 - Estimativa mineralógica apoiada em procedimentos de caracterização mineral .75

Figura 41 - Estimativa das fases portadoras de ferro por Mössbauer (\% em massa) 76

Figura 42 - Dendograma da análise por agrupamento para as 10 amostras selecionadas, identificando a estratégia a ser aplicada a cada tipo de amostra de bauxita (cut-off de 53) .80

Figura 43 - Dendograma da análise por agrupamento das amostras da pesquisa mineral $(P)$, segundo um cut-off de 53. Em amarelo, cut-off aplicado inicialmente...81 
Figura 44 - Dendograma da análise por agrupamento dos produtos de beneficiamento $(U)$, segundo um cut-off de 53. Em amarelo, cut-off aplicado inicialmente.

Figura 45 - Diagrama de análise do componente principal (três primeiros Eigenvalues) das 10 amostras selecionadas para análise por DRX-Rietveld, agrupadas em função da estratégia de refinamento a que foram submetidas

Figura 46 - Difratograma da amostra U06 refinado pelo método de Rietveld 85

Figura 47 - Quantificação mineralógica obtida por DRX-Rietveld para as principais fases $(>2 \%)$

Figura 48 - Diagramas de correlação entre as proporções de gibbsita, argilominerais e óxidos e hidróxidos de ferro obtidas pelas diferentes técnicas de quantificação mineral aplicadas

Figura 49 - Comparação entre as proporções de gibbsita, argilominerais e óxihidróxidos de ferro obtidas pelas diferentes técnicas de quantificação mineral aplicadas

Figura 50 - Diagramas de correlação entre resultados quantitativos obtidos por DRX com o método de Rietveld com as análises químicas específicas de controle do minério de bauxita (MRN), considerando-se os maiores constituintes das amostras90 Figura 51 - Ajustes dos espectros Mössbauer obtidos das amostras U06, P12, U13, $\mathrm{P} 13, \mathrm{P} 17$ 104

Figura 52 - Ajustes dos espectros Mössbauer obtidos das amostras P18, P20, U21, P26, P29 105

Figura 53 - Difratograma da amostra U06 refinado pelo método de Rietveld .........107

Figura 54 - Difratograma da amostra U13 refinado pelo método de Rietveld.........107

Figura 55 - Difratograma da amostra U21 refinado pelo método de Rietveld.........108

Figura 56 - Difratograma da amostra P17 refinado pelo método de Rietveld .........108

Figura 57 - Difratograma da amostra P20 refinado pelo método de Rietveld ........109

Figura 58 - Difratograma da amostra P29 refinado pelo método de Rietveld ........109

Figura 59 - Difratograma da amostra P18 refinado pelo método de Rietveld ........110 
Figura 60 - Difratograma da amostra P26 refinado pelo método de Rietveld .........110 Figura 61 - Difratograma da amostra P13 refinado pelo método de Rietveld .........111 Figura 62 - Difratograma da amostra P12 refinado pelo método de Rietveld .........111 


\section{LISTA DE TABELAS}

Tabela 1 - Composição química dos elementos maiores dos horizontes do perfil de alteração das bauxitas de Porto Trombetas (modificado de BOULANGÉ; CARVALHO, 1997)

Tabela 2 - Parâmetros Mössbauer de óx-hidr. de ferro com estrutura ideal para 297K (Bhf= campo magnético hiperfino; $\delta=$ deslocamento isométrico; $\varepsilon=$

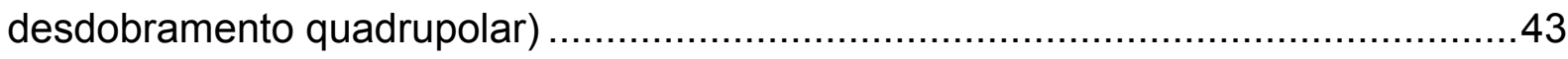

Tabela 3 - Composição química das amostras estudadas .....................................45

Tabela 4 - Condições instrumentais aplicadas na coleta dos difratogramas ............53

Tabela 5 - Resultados de classificação granulométrica..........................................69

Tabela 6 - Distribuição de teores nos produtos de separação mineral ......................71

Tabela 7 - Estimativa mineralógica apoiada em procedimentos de caracterização mineral .74

Tabela 8 - Parâmetros de Mössbauer e proporções das fases portadoras de ferro.75 Tabela 9 - Estratégias de refinamentos aplicadas à quantificação pelo método de Rietveld 78

Tabela 10 - Quantificação das proporções minerais por difração de raios $\mathrm{X}$ com o método de Rietveld 


\section{LISTA DE FOTOMICROGRAFIAS}

Fotomicrografia 1 - Imagem de MEV com detector de elétrons retroespalhados. Gibbsita (coloração cinza escuro), preferencialmente mista com massas de composição gibbsita-argilominerais (cinza mais claro) e minerais de ferro em branco

Fotomicrografia 2 - Imagem de MEV com detector de elétrons retroespalhados. Cristal límpido de gibbsita, sem outros elementos em sua estrutura

Fotomicrografia 3 - Imagem de MEV com detector de elétrons retroespalhados. Associação de gibbsita, massa gibbsita-argilominerais e dispersos cristalitos de óxihidróxidos de Fe e Ti (tons claros, brancos) .58

Fotomicrografia 4 - Imagem de MEV com detector de elétrons retroespalhados. Associação de cristal de gibbsita e a massa com intercrescimento de gibbsita e argilominerais; no detalhe à direita observam-se diminutos cristais de óxi-hidróxidos de Fe (cor branca) 59

Fotomicrografia 5 - Imagem de MEV com detector de elétrons retroespalhados. Detalhe para óxi-hidróxidos de $\mathrm{Fe}$, com aspecto poroso e heterogêneo 60

Fotomicrografia 6 - Mapeamento de raios $X$ na imagem à direita, ilustrando a distribuição dos elementos químicos na massa de gibbsita-caulinita. Gibbsita em azul, massa gibbsítica-caulinítica em tons azul-avermelhados, óxi-hidróxidos de $\mathrm{Fe}$ em verde e óxidos de Ti em amarelo. 60 


\section{LISTA DE ABREVIATURAS E SIGLAS}

ABAL

$\mathrm{Al}_{2} \mathrm{O}_{3}$ ap

CPRM

DNPM

DRX

DRX-Rietveld

EDS

FRX

GOF

ICDD

LCT - EPUSP

MEV

MRN

$\mathrm{P}$

PAN-ICSD

PCA

PF

$R_{\text {exp }}$

RTMS

$\mathrm{R}_{\mathrm{wp}}$

SDD

SEM

$\mathrm{SiO}_{2}$ re

U

WDS
Associação Brasileira do Alumínio

Alumina aproveitável

Companhia de Pesquisa e Recursos Minerais

Departamento Nacional de Pesquisa Mineral

Difração de raios $X$

Difração de raios $X$ associada ao método de Rietveld

Energy Dispersive Spectrometer

Fluorescência de raios $X$

Goodness-of-fit

International Centre for Diffraction Data

Laboratório de Caracterização Tecnológica da Escola Politécnica da

Escola Politécnica da Universidade de São Paulo

Microscopia eletrônica de varredura

Mineração Rio do Norte

Amostras referentes à pesquisa mineral

PANalytical Inorganic Crystal Structure Database

Análise de componentes principais

Perda ao fogo

$\mathrm{R}$ expected

Real Time Multiple Strip

R-weighted pattern

Silicon drift detector

Scanning Electron Microscopy

Sílica reativa

Amostras referentes a produtos de beneficiamento

Wavelengh Dispersive Spectrometer 


\section{RESUMO}

O projeto enfocou a aplicação da difração de raios $X(D R X)$ associada ao método de Rietveld na determinação quantitativa da composição mineralógica de bauxitas de Porto Trombetas, PA. Os resultados obtidos foram comparados com aqueles de outras ferramentas de determinação mineralógica, especificamente métodos tradicionais de caracterização de minérios e espectroscopia Mössbauer, além da correlação direta com dados de análises químicas que, atualmente, são utilizados no controle de pesquisa e processamento de bauxita.

Preliminarmente, definiram-se tipos mineralógicos de minério com o recurso de análise por agrupamento de dados de difração de raios $X$ para um conjunto de 60 amostras, englobando materiais da pesquisa mineral e do beneficiamento de bauxita pela Mineração Rio do Norte (MRN). Esse recurso permitiu otimizar o conjunto de amostras para o estudo e facilitar a definição de seqüências específicas de refinamento pelo método de Rietveld para grupos de amostras com composição mineralógica similar.

A DRX-Rietveld mostrou-se relevante e eficiente no estudo de bauxitas, sendo obtidos satisfatórios valores de indicadores estatísticos de refinamento (GOF e $R_{w p}$ ), além de elevada correlação linear com as demais metodologias aplicadas, particularmente no que se refere aos maiores constituintes das amostras, essencialmente gibbsita e argilominerais.

No caso de óxi-hidróxidos de ferro (basicamente hematita, goethita e uma fase de $\mathrm{Fe}^{3+}$ de baixa cristalinidade), com proporções inferiores a $20 \%$ nas amostras, verificou-se que parte desses minerais praticamente não foi detectada por DRXRietveld visto o grau de cristalinidade dessas fases, conforme observado por microscopia eletrônica de varredura e espectroscopia Mössbauer.

Palavras-chave: bauxita, difração de raios X, método de Rietveld. 


\begin{abstract}
This research concerns the application of X-ray diffraction (XRD) with Rietveld method in order to determinate the mineralogical composition of bauxites from Porto Trombetas, PA. The results were compared with the mineralogical composition obtained by mineral separations supported by chemical analysis and Mössbauer spectroscopy, as well as correlated with XRF chemical analysis and selective dissolution chemical analysis, that routinely support bauxite mineral research, mining operation as well as mineral processing.

Previously, a definition of mineralogical types was provided by cluster analysis of a 60 samples set of diffractograms, corresponding to geological research and beneficiation products from Mineração Rio do Norte (MRN). This tool simplified the analysis of a large number of data for the study and helped to establish the Rietveld refinement strategies for clusters of samples with similar mineralogical compositions.

XRD with Rietveld method showed to be relevant and efficient for bauxite study, giving satisfactory statistical evaluation parameters (GOF and $R_{w p}$ ), besides high linear correlation with the others mineralogical methods for the major minerals, essentially gibbsite and clay minerals.

For oxi-hydroxides minerals (basically hematite, goethite and a low crystallinity $\mathrm{Fe}^{3+}$ phase), with proportions bellow 20 percent of the samples, it could be seen that part of these minerals was not detected by XRD and so not evaluated by Rietveld quantification method, since they present low crystallinity as observed by scanning electron microscopy and Mössbauer spectroscopy.
\end{abstract}

Key-words: bauxite, X-ray diffraction, Rietveld method. 


\section{APRESENTAÇÃO}

\subsection{Introdução}

O interesse econômico do minério de bauxita depende de sua composição mineralógica, fundamentalmente das proporções de gibbsita e minerais de ganga contidos, que na prática é usualmente avaliada através de análises químicas específicas ou, mais raramente, de análises mineralógicas em estudos mais detalhados.

Análises químicas com procedimentos específicos fornecem teores de alumina aproveitável (gibbsita) e de sílica reativa (argilominerais) e constituem-se em prática rotineira de acompanhamento da pesquisa mineral e do processamento de bauxitas, simulando o comportamento do material frente ao processo Bayer de produção de alumina.

Esta dissertação aborda a utilização da técnica de difração de raios X (DRX) na caracterização mineralógica e na determinação das proporções minerais de amostras de bauxitas de origem sedimentar, especificamente as de ocorrência em Porto Trombetas, PA.

As amostras utilizadas foram selecionadas a partir de um conjunto de materiais de pesquisa geológica, obtidos de testemunhos de sondagem, e de produtos de beneficiamento, disponibilizados pela Mineração Rio do Norte (MRN).

Outras técnicas para determinação de composição mineralógica também foram utilizadas, especificamente métodos tradicionais de caracterização de minérios e espectroscopia Mössbauer.

\subsection{Objetivos}

O trabalho visou à avaliação da aplicabilidade da difração de raios $\mathrm{X}$ em apoio à pesquisa mineral e ao beneficiamento de bauxitas em um estudo de caso, como alternativa de substituição ou de complemento às práticas analíticas rotineiramente aplicadas na avaliação da qualidade do minério.

O desempenho da técnica de difração de raios $\mathrm{X}$, com apoio de programas de computação com recursos de análise por agrupamento (diferenciação de tipos 
mineralógicos) e de refinamento pelo método de Rietveld (quantificação de proporções minerais), foi verificado comparativamente a outras técnicas de determinação da composição mineral.

\subsection{Relevância do estudo}

Atualmente, a determinação de qualidade das referidas bauxitas é feita unicamente através de análises químicas via fluorescência de raios $X$ (FRX) para teores totais de $\mathrm{Al}_{2} \mathrm{O}_{3}, \mathrm{SiO}_{2}, \mathrm{Fe}_{2} \mathrm{O}_{3}$ e $\mathrm{TiO}_{2}$ e por via úmida, em métodos específicos para determinação de $\mathrm{Al}_{2} \mathrm{O}_{3}$ aproveitável e $\mathrm{SiO}_{2}$ reativa, esses últimos com resultados quantitativos correlacionáveis com o comportamento do minério na produção de alumina através do processo Bayer.

Essas análises via úmida envolvem procedimentos trabalhosos e morosos, com acurácia significativamente inferior à das análises de óxidos totais, constituindose em tópico crítico no desenvolvimento principalmente da pesquisa mineral, por imprimirem um ritmo bastante inferior ao dos trabalhos de campo na avaliação de frentes de lavra e de novos prospectos.

Alternativamente, têm sido aplicados cálculos estequiométricos empíricos para, a partir dos teores totais, serem estimados os conteúdos de $\mathrm{Al}_{2} \mathrm{O}_{3}$ aproveitável e $\mathrm{SiO}_{2}$ reativa (FERET; ROY, 2002) com base em composições químicas teóricas das espécies minerais e de uma taxa de solubilidade constante nas análises via úmida dos argilominerais associados ao minério. Esse método apresenta aceitável confiabilidade para acompanhamento da usina de beneficiamento cujo minério de alimentação da usina tem características controladas, sendo uma mistura (blendagem) de diferentes tipos de minérios; entretanto, não tem se mostrado suficiente e muitas vezes confiável na pesquisa de novas áreas e novos tipos de minério.

Análises quantitativas através da técnica de difração de raios $X$ já vêm sendo empregadas para a avaliação de bauxitas e de seus produtos de beneficiamento (KIRWAN et al., 2009), através de procedimentos ágeis e de baixo custo com resultados precisos. Nesse sentido, o presente trabalho busca avaliar a DRX como alternativa às análises por via úmida no estudo e avaliação de bauxitas formadas no contexto da Província Amazônica. 


\section{REVISÃO BIBLIOGRÁFICA}

\subsection{Aspectos geológicos dos depósitos de bauxita}

\subsubsection{Formações lateríticas}

No Brasil, com grande parte de seu território situado na faixa tropical do globo, as condições para o intemperismo laterítico existem pelo menos desde o início do Cenozóico, resultando numa área de 75\% do território nacional coberto por formações lateríticas (TOLEDO; OLIVEIRA; MELFI, 2000). Segundo esses autores, as referidas formações são ausentes apenas nas regiões nordeste de clima semiárido e sul de clima subtropical.

As condições favoráveis ao desenvolvimento dos processos intempéricos são o clima, que se expressa na variação sazonal da temperatura e na distribuição das chuvas; o relevo, que influi no regime de infiltração e drenagem das águas pluviais; a fauna e flora, que fornecem matéria orgânica para reações químicas e remobilizam materiais; a rocha parental, que, segundo sua natureza, apresenta resistência diferenciada aos processos de alteração intempérica; e, finalmente, o tempo de exposição da rocha a esses agentes. É necessário ainda que a região permaneça tectonicamente estável durante todo o período de laterização, pois movimentações tectônicas que causem mudanças no relevo podem ter como conseqüência variações nos regimes hidrológicos superficiais e/ou subsuperficiais, o que normalmente interrompe o processo de laterização e causa a destruição das lateritas anteriormente formadas (BIONDI, 2003).

Os principais recursos minerais relacionados a processos de laterização no Brasil são ferro, manganês, alumínio, níquel, nióbio e fósforo. Segundo Dardenne e Schobbenhaus (2000, 2001) e Toledo; Oliveira e Melfi (2000), depósitos minerais de origem laterítica podem ser classificados, quanto à natureza e origem dos minerais concentrados no perfil de alteração, em duas categorias:

- preservação do mineral primário de interesse e sua concentração por acumulação relativa, devido à lixiviação de parte da matéria do perfil geológico durante a alteração. Nesse caso, o mineral portador do 
elemento de interesse é relativamente estável e resistente ao intemperismo. O caso concerne, por exemplo, à hematita dos itabiritos.

- destruição dos minerais primários e formação de minerais secundários mais ricos no elemento químico de interesse, o que ocorre com elementos insolúveis, formando minerais secundários imediatamente após sua liberação dos minerais primários portadores, mas também pode ocorrer com elementos pouco solúveis, que migram no perfil de alteração e precipitam-se como fases secundárias nos horizontes que apresentem condições propícias para tal. Exemplos significativos incluem o alumínio, manganês, níquel, fósforo e nióbio.

\subsubsection{Depósitos de bauxitas lateríticas}

Especificamente os depósitos lateríticos de alumínio podem ser originados a partir de uma ampla variedade de rochas, pois, sendo um elemento usualmente abundante nas rochas e pouco solúvel em superfície, se concentra facilmente com a lixiviação intensa de outros componentes.

Os fatores mais influentes na geração desses depósitos são as condições morfotectônicas, que propiciam ambientes de drenagem livre para que ocorra a lixiviação de alguns elementos/minerais, e climáticas, caracterizadas por precipitação intensa e temperaturas altas.

O principal mineral de minério de um depósito de alumínio é um hidróxido, preferencialmente a gibbsita (no caso brasileiro; $\mathrm{Al}(\mathrm{OH})_{3}$ ) e, mais raramente, bohemita e/ou diásporo. Menores constituintes compreendem predominantemente argilominerais, principalmente caulinita $\left(\mathrm{Al}_{2} \mathrm{Si}_{2} \mathrm{O}_{5}(\mathrm{OH})_{4}\right)$, além de óxidos e hidróxidos de ferro (hematita - $\mathrm{Fe}_{2} \mathrm{O}_{3}$ e goethita - $\mathrm{FeO}(\mathrm{OH})$, respectivamente), óxidos de titânio $\left(\mathrm{TiO}_{2}\right)$ e sílica sob a forma de quartzo $\left(\mathrm{SiO}_{2}\right)$ (MASSOLA, 2008; TOLEDO, 1981).

As reservas brasileiras de bauxita (minério de alumínio), todas de origem laterítica, são estimadas em cerca de 3,5 bilhões de toneladas (somadas reservas medidas, indicadas e inferidas; ALUMíNIO; 2006). Segundo Melfi (1997), apesar de estarem amplamente espalhados pelo território brasileiro, os depósitos de bauxitas concentram-se nas regiões Amazônica (Província Amazônica), Quadrilátero Ferrífero 
e Província da Mantiqueira Central (Província Centro-Leste) e, por fim, na região SulSudeste do país (Província Alcalina), conforme ilustrado na Figura 1.

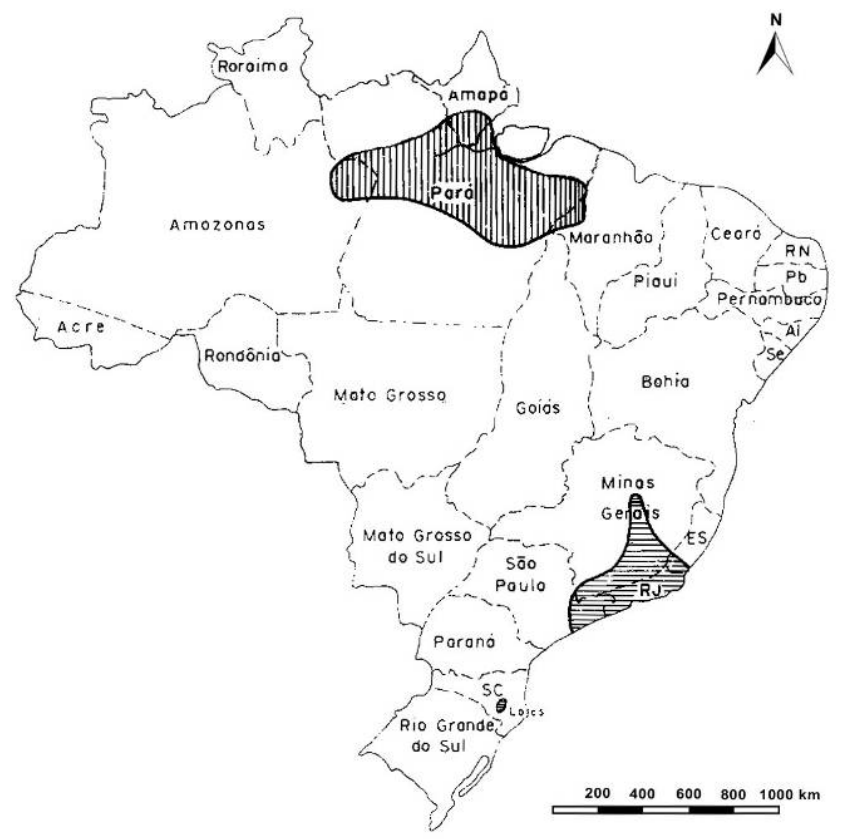

Figura 1 - Localização das grandes regiões de depósitos de bauxita no Brasil (HERNALSTEENS; LAPA, 1988)

Especificamente $97 \%$ desses depósitos estão concentrados na região Amazônica, com clima equatorial, onde são desenvolvidos principalmente sobre rochas sedimentares clásticas areno-argilosas de origem continental, com exceção de Carajás, com bauxitas formadas a partir de rochas básicas. Peixoto e Horbe (2008) detalham a ocorrência de bauxitas originadas a partir de rochas ígneas, vulcânicas e granitos, no nordeste do Amazonas.

Na região do Quadrilátero Ferrífero, de clima tropical úmido, os depósitos foram originados a partir de rochas sedimentares, metassedimentares e metavulcânicas (MELFI, 1997), enquanto na região sudeste de Minas Gerais, ainda de clima tropical úmido, foram formados a partir de rochas granulíticas. Na região Sul-Sudeste, com clima subtropical, as condições climáticas são menos favoráveis, porém as bauxitas foram formadas a partir de rochas alcalinas, originalmente ricas em Al (CARVALHO; BOULANGÉ; MELFI, 1991).

Os depósitos de bauxita da Amazônia (BÁRDOSSY; ALEVA, 1990) ocorrem no topo de platôs dissecados pela erosão, em altitudes que geralmente variam entre 70-120 metros em relação ao nível do rio Amazonas e apresentam-se separados por 
vales de larguras quilométricas que hospedam a atual rede de drenagem (KOTSCHOUBEY et al., 2005). São delimitados por flancos escarpados (inclinação de $30^{\circ}$ ) e apresentam superfície aproximadamente plana, com suaves ondulações e inclinação em torno de $1-5^{\circ}$ em direção ao rio Amazonas, além de recobrimento denso por vegetação característica de florestas tropicais (FLÔRES, 1997).

Na região, o clima é considerado quente e úmido, com temperatura média anual entre $24-26^{\circ} \mathrm{C}$ e pluviosidade variando de $1.500-2.500 \mathrm{~mm} /$ ano a valores superiores a 2.500 mm/ano em alguns locais (BOULANGÉ; CARVALHO, 1997).

Segundo Dardenne e Schobbenhaus (2003), na distribuição dos horizontes no perfil de alteração reside a originalidade das bauxitas da Amazônia bem como a existência de específicos horizontes (capeamento caulinítico e leito nodular ferruginoso intercalado entre dois níveis de bauxita) que geram controvérsias em relação à evolução dos perfis de alteração e, conseqüentemente, aos modelos genéticos de formação sumariados a seguir:

- modelo alóctone de alteração polifásica, por Truckenbrodt; Kotschoubey e Schellmann (1991) e Kotschoubey et al. (2005), que considera a argila caulinítica de capeamento como sedimentos depositados por aporte lateral, em ambiente lacustre após a formação das bauxitas, selando a evolução do perfil de alteração.

- modelo autóctone de alteração polifásica, por Boulangé e Carvalho (1997), que advoga em favor de uma evolução contínua in situ, essencialmente a partir da alteração dos sedimentos argilo-arenosos.

Ambos os modelos consideram os demais horizontes como sendo resultado de diferentes fases de bauxitização, com alternâncias climáticas e variações de cobertura vegetal, durante as quais ocorreram remobilizações e redistribuições de elementos em solução ao longo do perfil. Fenômenos de ressilicificação e dessilicificação, por exemplo, seriam responsáveis pela formação dos horizontes de caulinita e bauxita, respectivamente. Horbe et al. (2001) destacam ainda que em intervalos de clima úmido e de maior estabilidade tectônica predomina o intemperismo químico in situ das rochas, cuja intensidade e ciclicidade permitem o desenvolvimento de horizontes mais espessos e estratificados, conduzindo a formação de níveis aluminosos (bauxita) em estágios avançados de bauxitização, 
enquanto períodos de clima seco seriam responsáveis pelo desenvolvimento de crostas ferruginosas.

\subsubsection{Bauxita de Porto Trombetas, PA}

Inserido na denominada Bacia Amazônica Baixa (BOULANGÉ; CARVALHO, 1997), o depósito de bauxita de Porto Trombetas no estado do Pará localiza-se na margem do rio Trombetas, no município de Oriximiná, a aproximadamente $900 \mathrm{~km}$ a oeste da cidade de Belém, como mostra a Figura 2. Sua reserva é avaliada em cerca de 600 milhões de toneladas de minério, com teor médio de cerca de $50 \%$ de $\mathrm{Al}_{2} \mathrm{O}_{3}$ e $4 \%$ de sílica reativa (VALE, 2009).

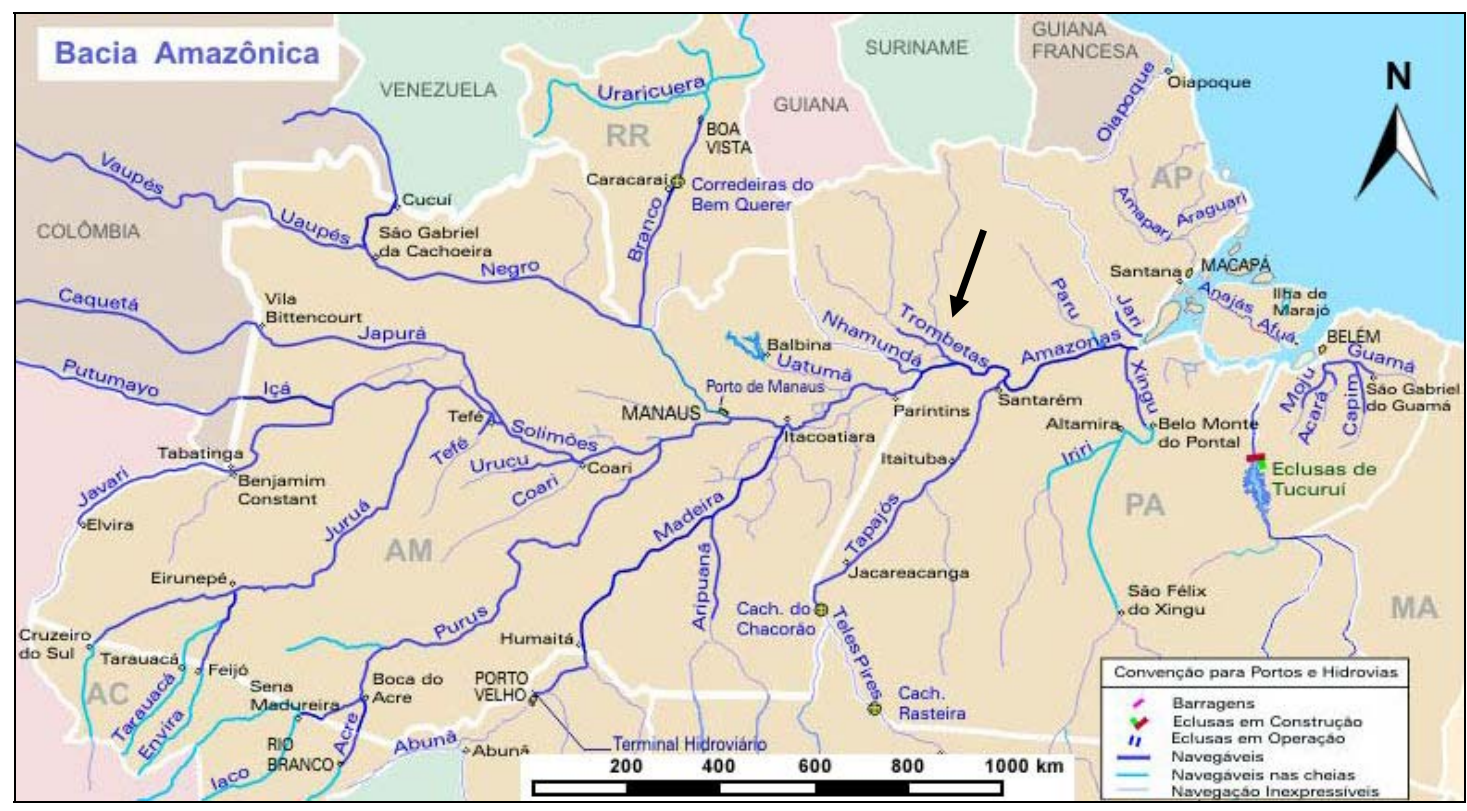

Figura 2 - Mapa de localização do rio Trombetas, PA - Brasil (TROMBETAS, 2009)

A mineralização de bauxita ocorre em diversos platôs que, juntos, cobrem uma área de pelo menos $2.200 \mathrm{~km}^{2}$. Atualmente são lavrados pela Mineração Rio do Norte os platôs denominados Saracá, Almeidas e Aviso.

A Figura 3 refere-se ao mapa geológico da região onde está localizado o depósito de bauxita de Porto Trombetas, desenvolvido sobre rochas sedimentares clásticas areno-argilosas de origem continental da Formação Alter do Chão (Mesozóico), cuja espessura excede $600 \mathrm{~m}$ e constitui-se de argilitos e arenitos arcoseanos, intercalados com conglomerados e siltitos (BOULANGÉ; CARVALHO, op. cit.). Essas rochas se apresentam em contato discordante sobre sedimentos Paleozóicos. 


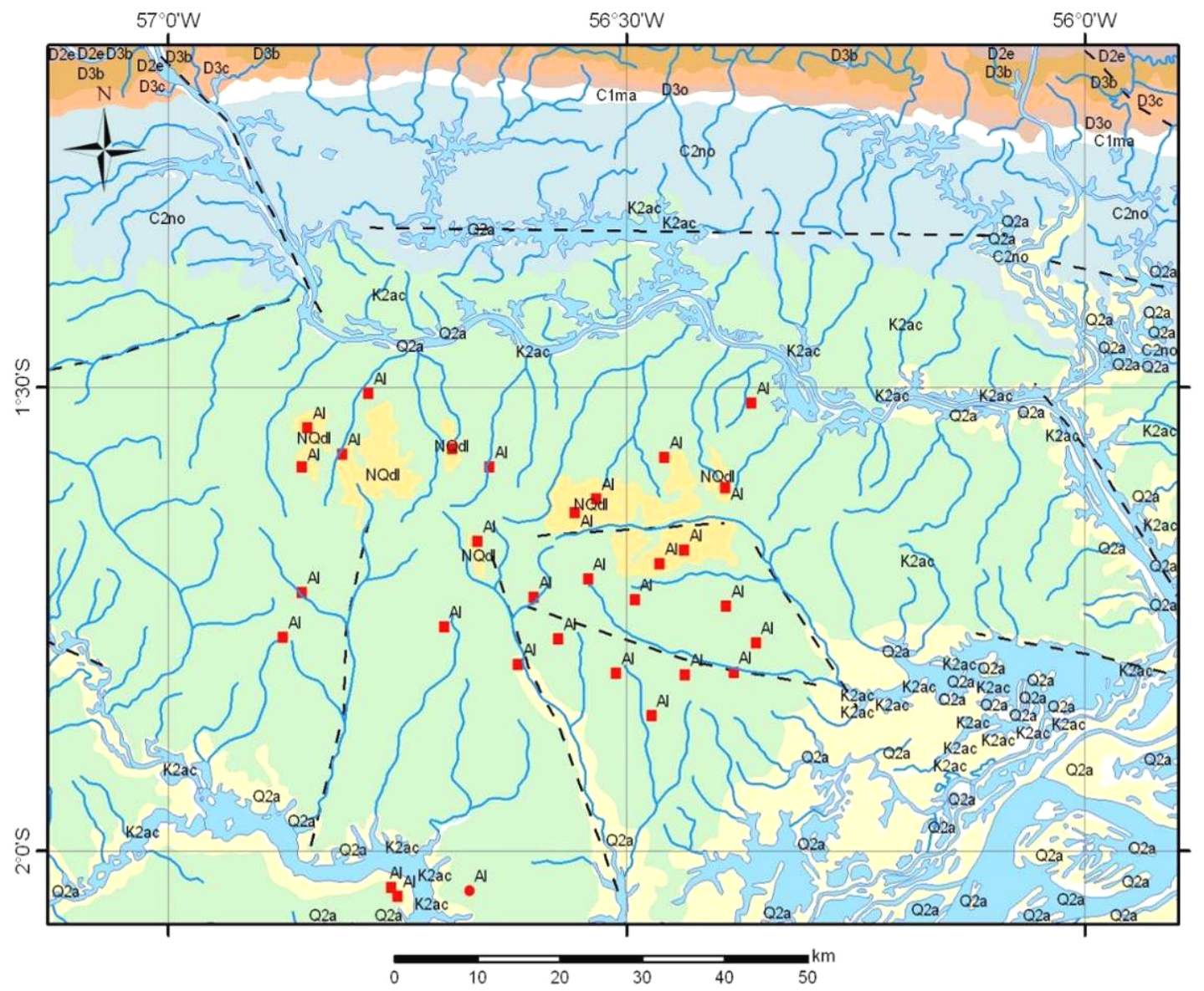

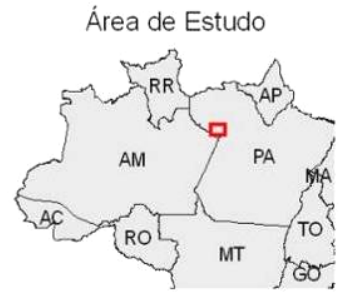

Localização na Folha Santarém

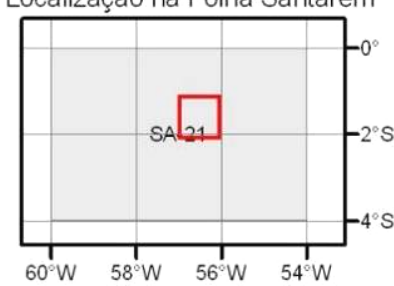

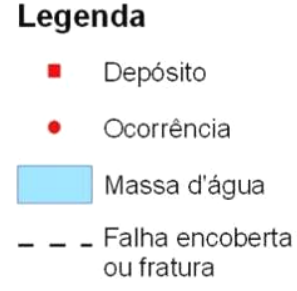

Legenda

- Ocorrência

Falha encoberta

\author{
Geologia \\ QUATERNÁRIO \\ Q2a Depósitos aluvionares \\ TERCIÁRIO \\ NQdI Cobertura Detrito-laterítica \\ CRETÁCEO \\ K2ac Formaçăo Alter do Chão \\ CARBONÍFERO \\ Grupo Tapajós \\ C2no Formação Nova Olinda \\ DEVONIANO \\ Grupo Curuá \\ D3c Formação Curiri \\ D3b Formação Barreirinha \\ D2e Formação Ererê
}

Figura 3 - Mapa geológico regional ao milionésimo, onde se localizam os platôs referentes ao depósito de bauxitas de Porto Trombetas, PA (modificado de CPRM, 2004)

Nos vários platôs, a mesma seqüência de horizontes é observada em praticamente toda sua extensão (seqüência, não muito diferente de outros depósitos encontrados na Amazônia) e pode ser descrita do topo para a base como:

(a) cobertura superficial constituída por horizonte de argila caulinítica; 
(b) zona mineralizada subdividida em bauxita nodular, sobre laterita ferruginosa, sobre bauxita maciça gibbsítica;

(c) zona saprolítica ou argilosa (caulinita), como mostra a Figura 4.
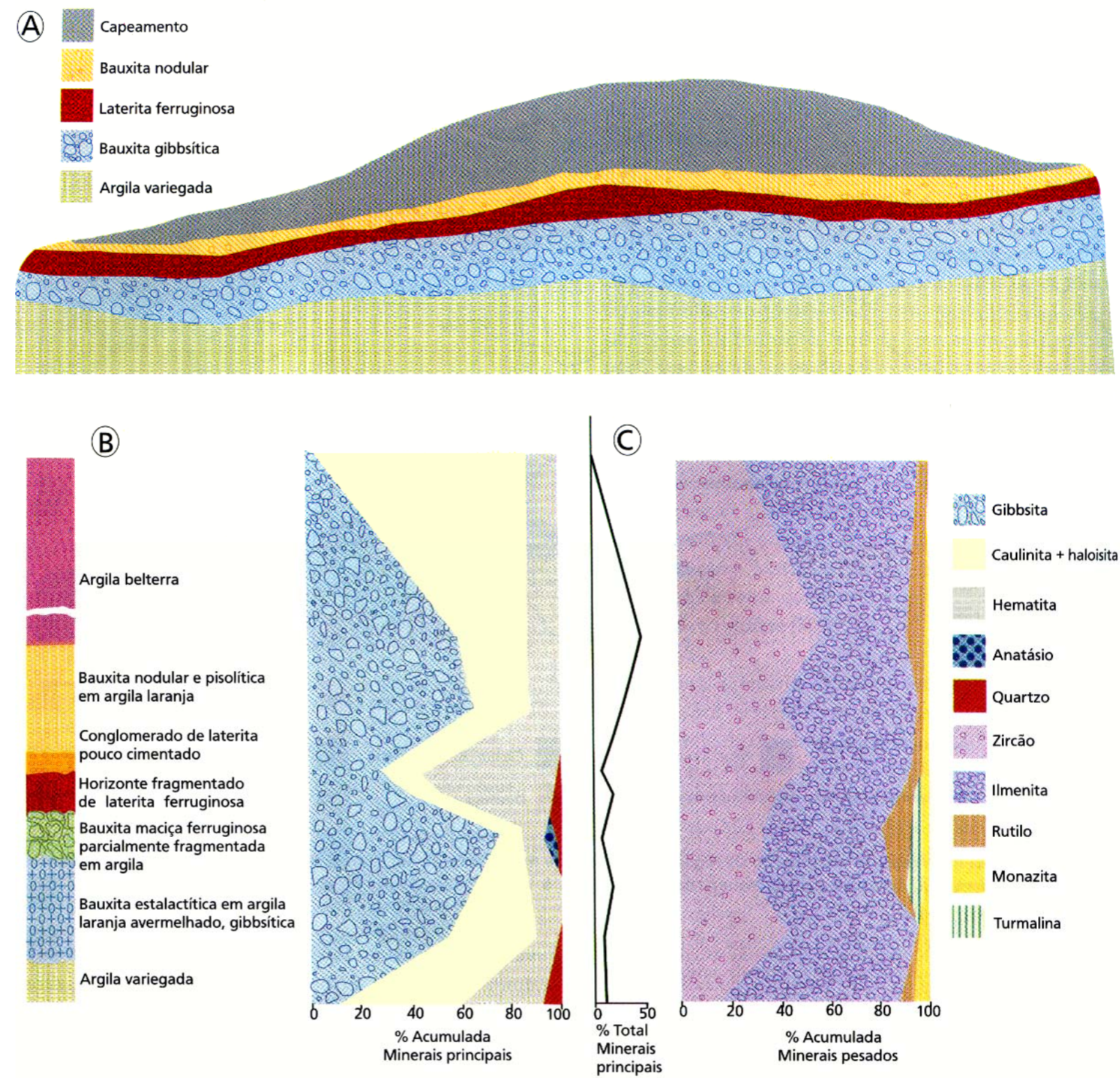

Figura 4 - Seção geológica-tipo (A) e coluna estratigráfica (B) dos depósitos de bauxita de Porto Trombetas, Pará. (C) Minerais principais e minerais pesados dos horizontes do perfil de alteração. (HERNALSTEENS; LAPA, 1988, apud BIONDI, 2003)

Segundo Boulangé e Carvalho (op. cit.), o horizonte laterítico ocorre recoberto por uma camada de argila caulinítica de cor amarela-avermelhada, considerada homogênea e sem aparente estratificação, com espessura variando entre 8-10 metros de espessura; compõe-se principalmente por caulinita e, em menores quantidades, quartzo e gibbsita, e é denominada de argila Belterra. 
O leito subseqüente refere-se à bauxita nodular, que varia de 1-3 metros de espessura e corresponde a nódulos heterogêneos de gibbsita $(<5 \mathrm{~cm})$ imersos numa matriz argilo-caulinítica alaranjada, sendo que nas porções mais basais estão presentes ainda nódulos ferruginosos. A laterita ferruginosa nodular corresponde ao terceiro horizonte, com cerca de 1 metro de espessura e compreende nódulos ferruginosos $(\sim 10 \mathrm{~cm})$ de coloração vermelho-violeta, cimentados por uma matriz preferencialmente gibbsítica, por vezes caulinítica.

Sob o leito ferruginoso encontra-se outra camada de bauxita, com espessura variando entre 1-6 metros, que atualmente refere-se ao horizonte que confere interesse econômico ao minério, devido à sua elevada concentração em gibbsita. $A$ parte superior desta camada é constituída por uma carapaça maciça e compacta de bauxita alumino-ferruginosa de aproximadamente 1 metro de espessura. A porção inferior e mais espessa é formada por bauxita com texturas variáveis (porosa, sacaróide, terrosa, granular e celular; FLÔRES, 1997), correspondendo a grandes blocos e fragmentos residuais de rocha, materiais argilosos amarelo-avermelhados. Microscopicamente a bauxita aparece na forma de gibbsita bem cristalizada (BOULANGÉ; CARVALHO, op. cit).

O leito inferior corresponde a uma argila caulinítica variegada, composta por nódulos reliquiares de gibbsita e hematita dispostos em uma matriz argilosa.

Um sumário da composição química dos horizontes descritos é exposto na Tabela 1.

Tabela 1 - Composição química dos elementos maiores dos horizontes do perfil de alteração das bauxitas de Porto Trombetas (modificado de BOULANGÉ; CARVALHO, 1997)

\begin{tabular}{|c|c|c|c|c|c|}
\hline \multirow{2}{*}{ Horizonte } & \multicolumn{5}{|c|}{ Óxidos (\% em peso) } \\
\hline & $\mathrm{Al}_{2} \mathrm{O}_{3}$ & $\mathrm{SiO}_{2}$ & $\mathrm{Fe}_{2} \mathrm{O}_{3}$ & $\mathrm{TiO}_{2}$ & PF \\
\hline Capeamento caulinítico & $34,8-37,9$ & $34,5-38,9$ & $7,90-8,60$ & $2,70-2,80$ & $14,8-16,5$ \\
\hline Bauxita nodular & & & & & \\
\hline matriz & $43,3-43,4$ & $25,9-26,5$ & $7,40-9,20$ & $2,10-2,40$ & $19,0-19,9$ \\
\hline nódulos & 61,2 & 4,30 & 2,20 & 1,10 & 30,6 \\
\hline Laterita ferruginosa & & & & & \\
\hline matriz & 29,0 & 22,8 & 31,1 & 2,20 & 14,5 \\
\hline nódulos de ferro & 19,1 & 18,8 & 50,3 & 0,77 & 10,5 \\
\hline Bauxita gibbsítica & & & & & \\
\hline superior - porções claras & 60,2 & 2,10 & 5,00 & 0,71 & 31,3 \\
\hline superior - porções escuras & $47,4-55,3$ & $0,63-0,95$ & $13,7-25,5$ & $0,88-0,96$ & $25,5-28,5$ \\
\hline inferior & $53,7-61,6$ & $2,80-8,50$ & $2,80-6,60$ & $0,68-2,70$ & $27,9-31,3$ \\
\hline Argila & $35,2-44,7$ & $25,3-38,3$ & $7,25-15,4$ & $1,65-4,05$ & $14,0-20,5$ \\
\hline
\end{tabular}




\subsection{Explotação de bauxita}

\subsubsection{Lavra}

O principal procedimento de lavra para minérios de bauxita relaciona-se ao método por tiras (strip mining), a céu aberto, onde faixas regulares de minério são escavadas de forma mecanizada, sem uso de explosivos, conforme apresentado na Figura 5 (HILL; SEHNKE, 2006).

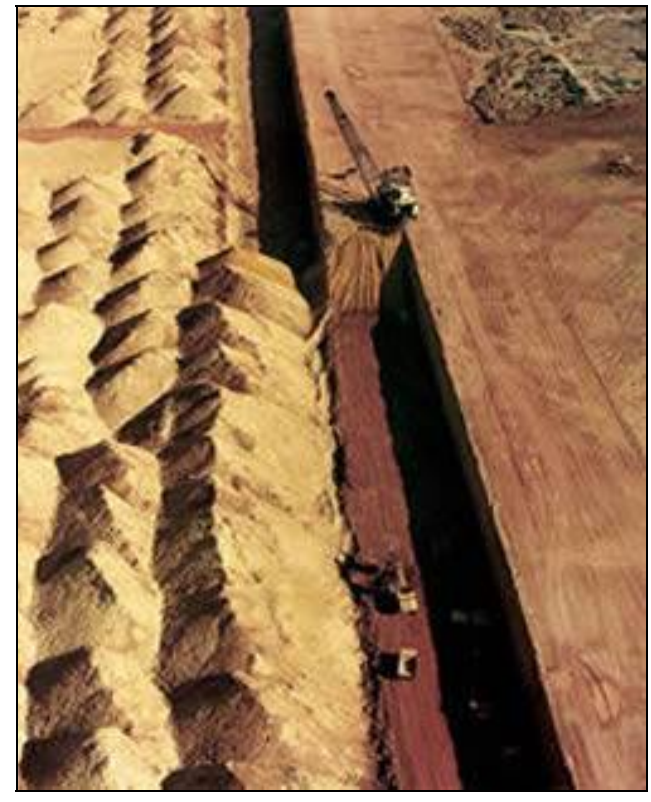

Figura 5 - Procedimento em tiras na lavra de bauxitas (ABAL, 2009)

Nota-se que o material estéril de capeamento é também escavado pelo método por tiras e, posteriormente, depositado na faixa adjacente, na qual o minério já foi lavrado (MRN, 2009). A remoção da vegetação, do solo orgânico e, finalmente, do material estéril é realizada de maneira bastante criteriosa, de forma ambientalmente planejada para uso posterior no processo de recuperação da área lavrada (SAMPAIO; ANDRADE; DUTRA, 2005).

\subsubsection{Beneficiamento mineral}

O beneficiamento de minérios de bauxita para fins metalúrgicos tem por objetivo a obtenção de um produto concentrado com razão mássica $\mathrm{Al}_{2} \mathrm{O}_{3} / \mathrm{SiO}_{2}$ superior a 10, interferente sobre o processo Bayer (SAMPAIO; ANDRADE; DUTRA, 2005). O processamento do minério engloba basicamente as seguintes etapas, ilustradas também na Figura 6 a Figura 11 (CHAVES; MASSOLA, 2007). 
- britagem: liberação de minerais, promovendo a redução da granulometria do material ao máximo de 3 polegadas (MRN, 2009);

- lavagem: relacionada à atrição (escrubagem), peneiramento e deslamagem do minério para a remoção de partículas finas constituídas essencialmente por argilominerais e óxi-hidróxidos de ferro impregnadas à superfície da gibbsita, além da retirada de minerais de titânio, quartzo e demais constituintes;

- secagem ou desaguamento: efetuada através de operações mecânicas com peneiras e ciclones e/ou por etapas de filtragem a vácuo.

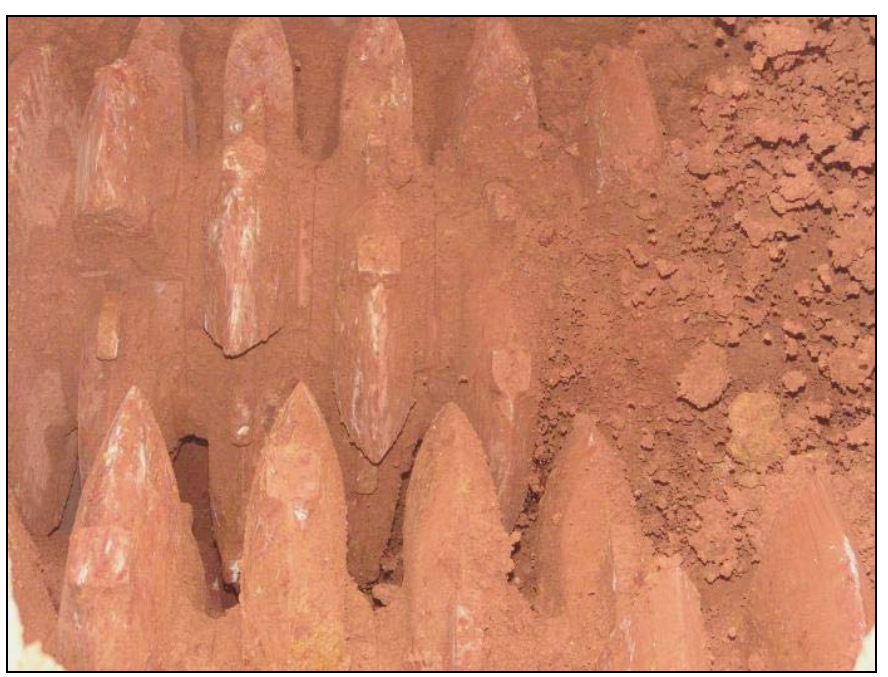

Figura 6 - Britagem no beneficiamento de bauxita da MRN (Foto: Henrique Kahn)

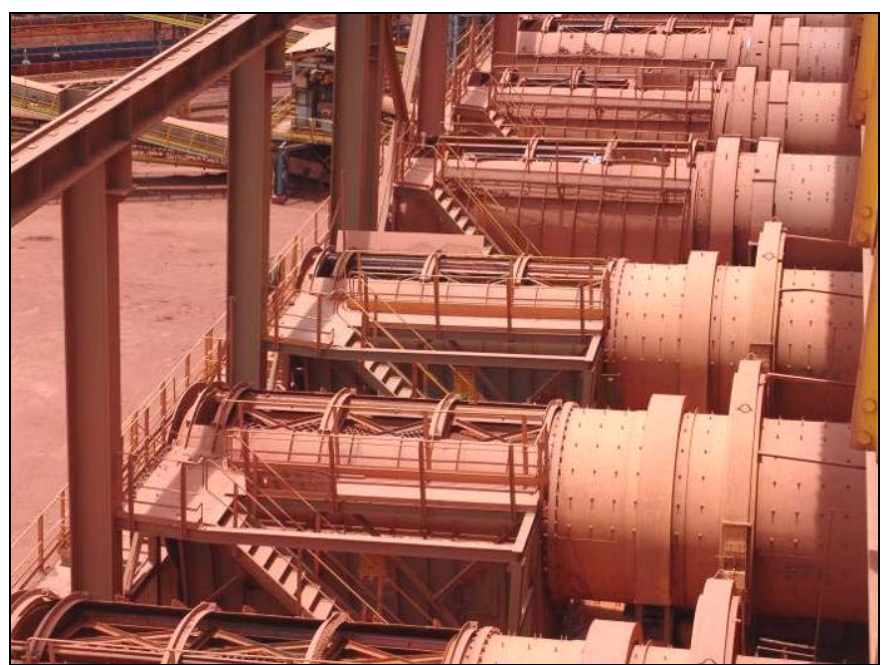

Figura 7 - Atrição no beneficiamento de bauxita da MRN (Foto: Henrique Kahn) 


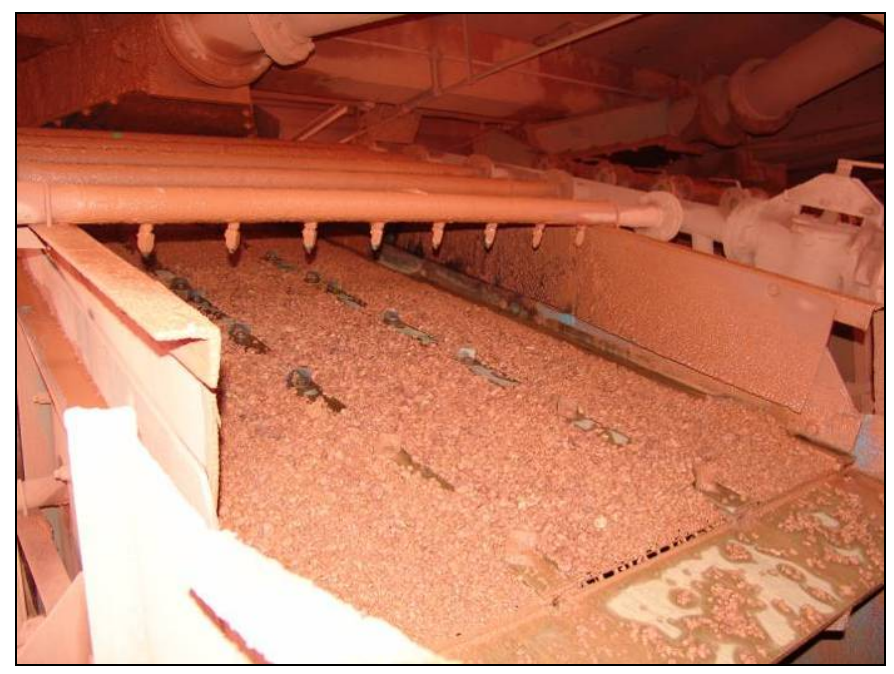

Figura 8 - Peneiramento no beneficiamento de bauxita da MRN (Foto: Henrique Kahn)

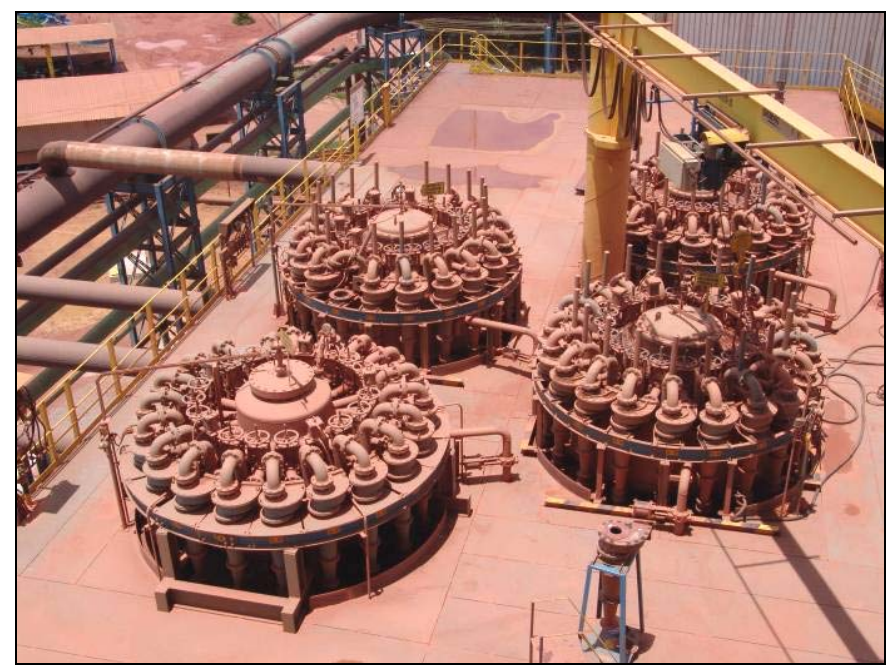

Figura 9 - Secagem (ciclones) no beneficiamento de bauxita da MRN (Foto: Henrique Kahn)

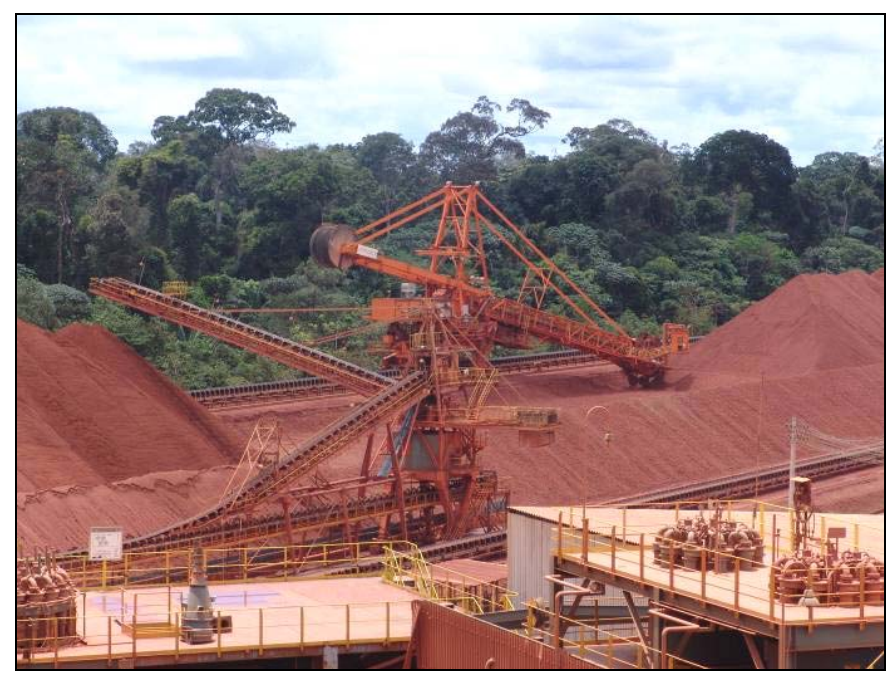

Figura 10 - Pilha de produto beneficiado de bauxita da MRN (Foto: Henrique Kahn) 


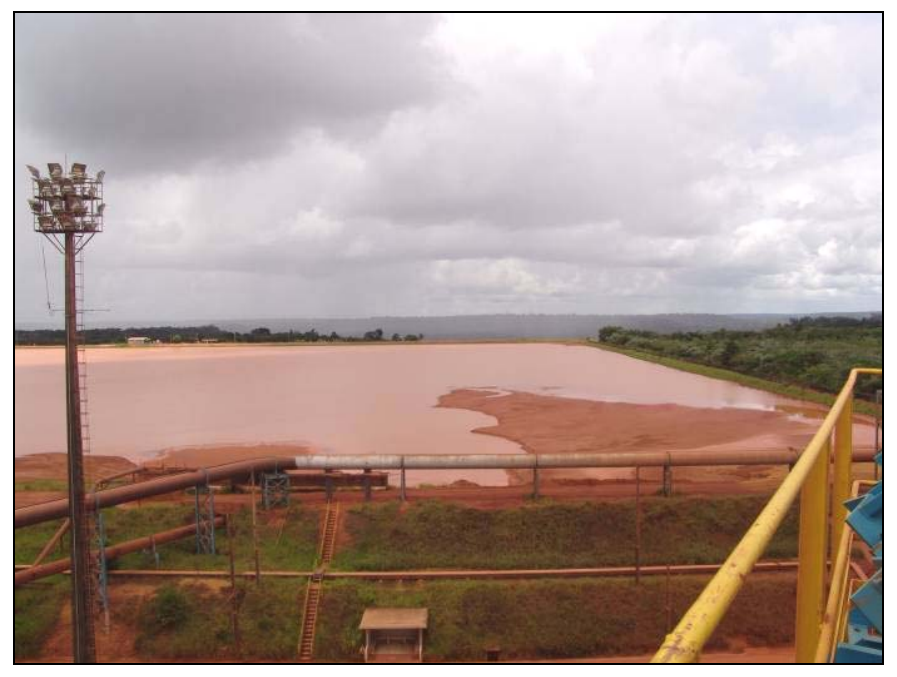

Figura 11 - Barragens de finos da MRN (Foto: Henrique Kahn)

Embora não usuais, operações posteriores de separações densitárias, separações magnéticas e flotação podem ainda ser realizadas na concentração do minério de bauxita.

Do processo de beneficiamento resultam em torno de $25-30 \%$ de massa sólida como rejeito de bauxita, depositado em barragens de finos usualmente construídas em áreas já mineradas (MRN, 2009).

\subsubsection{Processo hidrometalúrgico - processo Bayer}

$\mathrm{O}$ processo Bayer tem por objetivo a produção de alumina pura $\left(\mathrm{Al}_{2} \mathrm{O}_{3}\right)$, a partir de reações químicas promovidas por adições de soda cáustica, ao mesmo tempo em que se realizam atividades de clarificação, precipitação e calcinação (HILL; SEHNKE, 2006; MASSOLA, 2008).

Inicialmente tem-se a digestão do minério de bauxita em uma solução de hidróxido de sódio ( $\mathrm{NaOH}$; soda cáustica) sob temperatura e pressão elevadas, dando origem a uma solução de aluminato de sódio $\left(\mathrm{NaAlO}_{2}\right)$ e precipitados insolúveis conhecidos como "lama vermelha", correspondendo, essencialmente, a minerais de ferro e titânio.

Posteriormente, a solução é resfriada e a "lama vermelha" é removida por espessamento e filtragem (etapa de clarificação). O licor de aluminato de sódio é purificado tanto quanto possível, por filtragem, antes de ser enviado aos tanques 
precipitadores de hidróxido de alumínio $\left(\mathrm{Al}(\mathrm{OH})_{3}\right.$; gibbsita) e, em seguida, aos fornos de calcinação para originar a alumina pura $\left(\mathrm{Al}_{2} \mathrm{O}_{3}\right)$.

A alumina aproveitável ou disponível no minério refere-se à parcela de alumina com propriedades tais que pode ser solubilizada pelo $\mathrm{NaOH}$, sendo oriunda essencialmente dos hidróxidos de alumínio (gibbsita e outros); teores de alumina remanescentes são referentes a argilominerais (essencialmente caulinita). A sílica, por sua vez, ocorre de duas formas principais: sílica reativa, relativa aos argilominerais citados, e quartzo dentre outros silicatos menores (ULSEN et al., 2007).

A sílica livre (quartzo) tem comportamento inerte no processo Bayer para a produção de alumina, enquanto que, durante a digestão, a caulinita é também atacada pela soda cáustica e, juntamente com a solução de aluminato de sódio, gera um composto silicático insolúvel $\left(2 \mathrm{Na}_{2} \mathrm{O} .2 \mathrm{Al}_{2} \mathrm{O}_{3} \cdot 3 \mathrm{SiO}_{2} \cdot 2 \mathrm{H}_{2} \mathrm{O}\right.$; bayerita) que é descartado do processo junto à lama vermelha. A presença de argilominerais reflete, portanto, no aumento do consumo de soda cáustica, diminuição de recuperação metalúrgica, e conseqüente elevação do custo da produção.

Depois de originada a alumina, a mesma é levada a uma unidade produtiva de alumínio metálico (smelter) através do processo de redução eletrolítica, conhecido como Hall-Héroult. 


\subsection{Difração de raios $X$}

Neste capítulo são abordados os fundamentos da técnica de difração de raios $X$, sendo focadas, dentre as diversas aplicações, as análises qualitativas e quantitativas de fases minerais, relacionadas ao objetivo desta dissertação.

\subsubsection{A geração dos raios $X$}

Os raios $X$ são ondas eletromagnéticas de comprimento de onda compreendido no intervalo de 0,1 a $700 \AA$; aplicações no estudo de estruturas de materiais no nível de distâncias interatômicas empregam comprimentos de onda de 0,2 a 2,5 Å (KLUG; ALEXANDER, 1974).

Segundo Arnold e Chung (1992), esses raios são originados em tubos de vidro sob vácuo. Inserido ao tubo, conforme ilustrado na Figura 12, um filamento de tungstênio (W) é utilizado como cátodo, o qual é submetido a uma diferença de potencial, gerando uma corrente elétrica de feixe de elétrons acelerados em direção a um ânodo metálico (exemplos, $\mathrm{Cu}, \mathrm{Cr}, \mathrm{Fe}, \mathrm{Co}$ ). Após ser bombardeado pelos elétrons oriundos do cátodo, o ânodo emite uma nova radiação, denominada de radiação $\mathrm{X}$. Em razão de seu aquecimento pelo bombardeamento de elétrons, o ânodo é resfriado por um sistema de circulação de água.

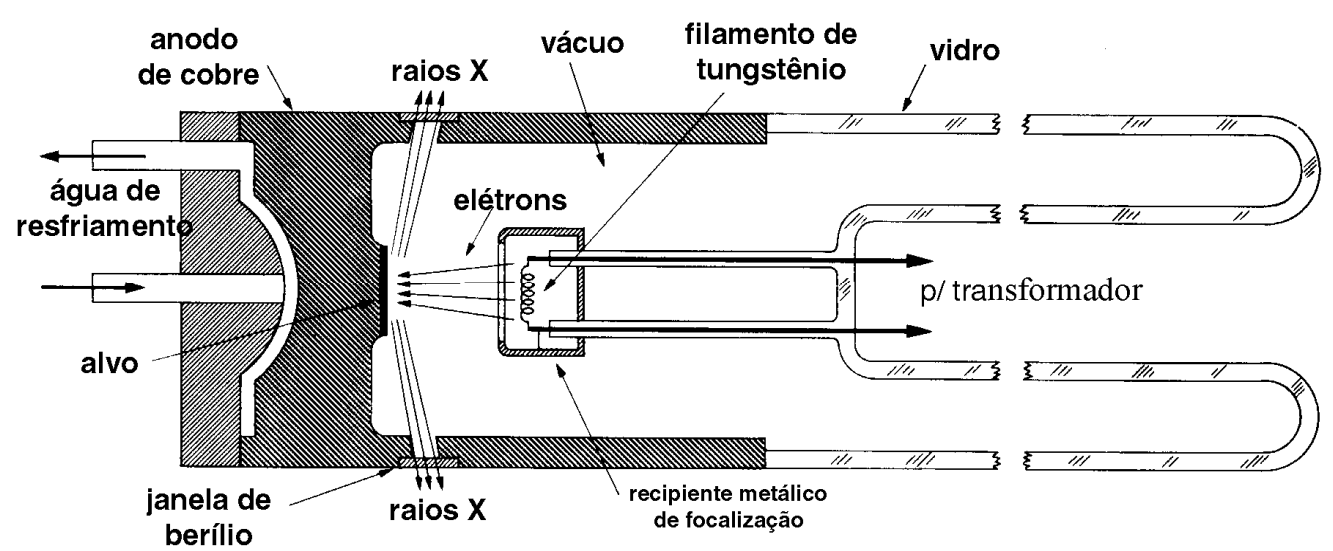

Figura 12 - Corte longitudinal de um tudo de raios X tradicional (adaptado de Cullity, 1978)

A produção dos raios $X$ é, portanto, uma conseqüência da colisão entre os elétrons acelerados vindo do cátodo (I) com o elétron bombardeado no átomo do ânodo, como ilustrado na Figura 13. O elétron bombardeado é arrancado para fora de sua camada (II) e a vacância (espaço) deixada por ele é reocupada por outro 
elétron, de maior energia, vindo de uma camada mais externa (III). Este ganho em energia potencial à sua camada é liberado na forma de um fóton de raios $\mathrm{X}$ (IV; raios $X$ característico). Adicionalmente, são também gerados raios $X$ de energia não específica, correspondentes ao espectro contínuo.
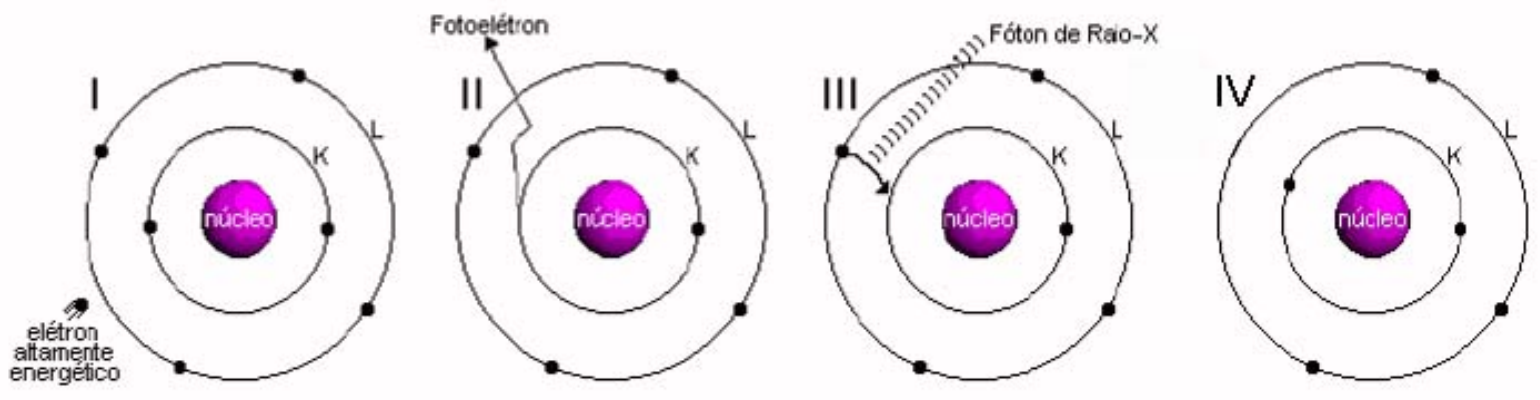

Figura 13 - A produção de raios X a nível atômico (BLEICHER; SASAKI, 2000)

O espectro de radiação gerado a partir do tubo de raios $X$ não é monocromático, apresentando tanto a radiação característica do material empregado como ânodo ( $\mathrm{K}_{\alpha}, \mathrm{K}_{\beta}$ etc), como também do espectro contínuo emitido pelo tubo, exemplificados pela Figura 14.

A)

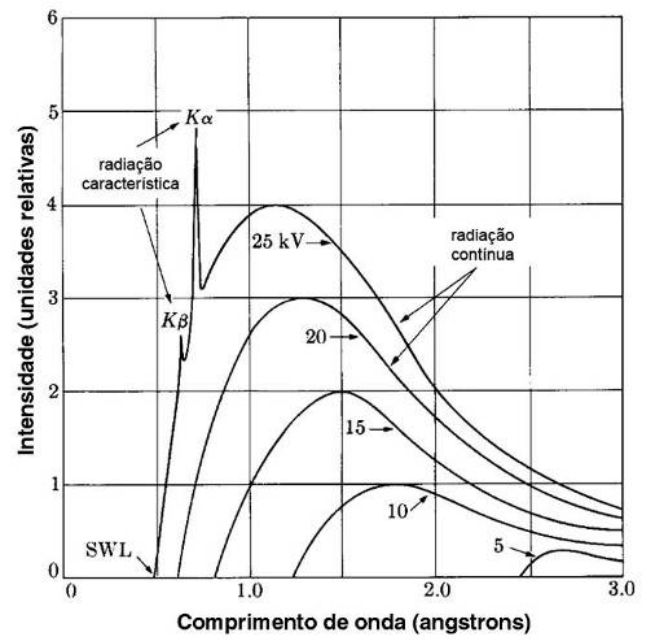

B)

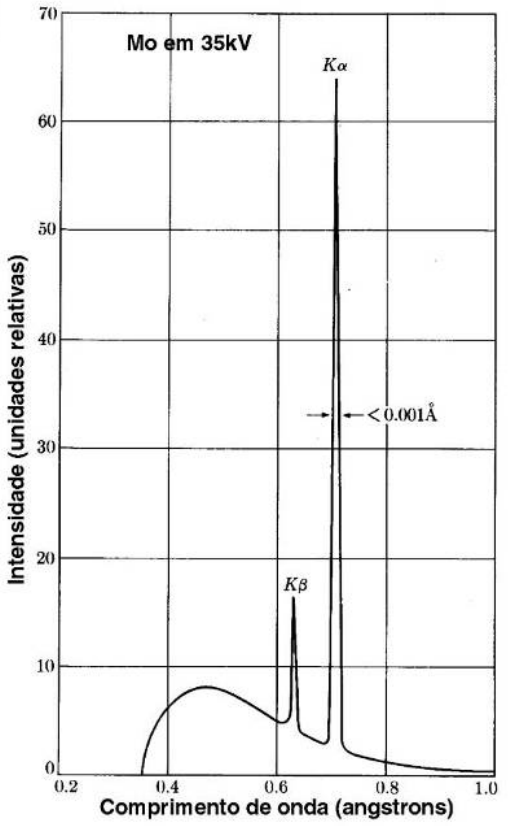

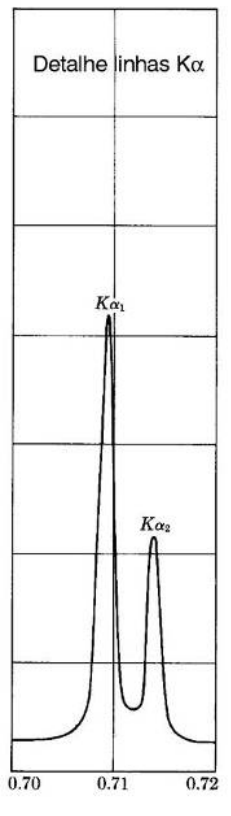

Figura 14 - Espectros de raios $X$ contínuo e característico para o molibdênio a $35 \mathrm{kV}$ (A e B). À direita é detalhado o dubleto $\mathrm{Ka}_{1}$ e $\mathrm{Ka}_{2}$ referente à linha $\mathrm{Ka}$ (adaptado de Cullity, 1978)

Considerando que a radiação característica de interesse da técnica de difração de raios $X$ é a $K_{\alpha}$ na forma de uma radiação monocromática, há 
necessidade de se remover a radiação referente à linha $K_{\beta}$ e também parte do espectro contínuo emitido pelo tubo. Para isso podem ser utilizados filtros cujas bandas de absorção de radiação permitam, através de um fenômeno de absorção, a passagem da radiação referente à linha $\mathrm{K}_{\alpha}$, como o exemplo de filtro de Ni para a radiação $\mathrm{CuK}_{\beta}$ e/ou filtro monocromador empregando o princípio da difração de raios X (PAIVA-SANTOS; ANTONIO, 2003).

\subsubsection{Princípios da difração de raios $X$}

A difração de raios $X$ representa o fenômeno de interação entre um feixe incidente de raios $X$ e os elétrons dos átomos componentes de um material, sendo posteriormente detectados os fótons difratados, que constituem o feixe difratado.

Segundo Jenkins e Snyder (1996), ao atingirem um material, os raios $X$ podem ser espalhados elasticamente, sem perda de energia pelos elétrons dos átomos (espalhamento coerente). $O$ fóton de raios $X$, após a colisão com o elétron da amostra, muda sua trajetória, mantendo, porém, o mesmo comprimento de onda da radiação incidente. Sendo assim, cada elétron é atuante, instantaneamente, como um novo centro de emissão de raios $X$.

Se os átomos que geram este espalhamento estiverem arranjados de maneira sistemática, como em uma estrutura cristalina, pode-se verificar que as relações de fase entre os espalhamentos tornam-se periódicas e que o fenômeno de difração dos raios $X$ é observado em vários ângulos de incidência do feixe, desde que seu comprimento de onda $\lambda$ seja da ordem de grandeza das distâncias entre os centros espalhadores - $d$, como resultado de uma interferência construtiva e ocorrendo nas direções de espalhamento que satisfazem a Lei de Bragg, como ilustrado na Figura 15. A teoria da difração de raios $X$ é detalhada por Cullity (1978).

A Lei de Bragg é expressa pela Equação a seguir.

$$
\mathrm{n} \lambda=2 \mathrm{~d} \operatorname{sen} \theta
$$

onde, $\lambda$ corresponde ao comprimento de onda da radiação incidente, "n" à ordem de difração (número inteiro), "d" à distância interplanar para o conjunto de planos hkl (índice de Miller) da estrutura cristalina e $\theta$ ao ângulo de incidência dos raios $X$ (medido entre o feixe incidente e os planos cristalinos). 


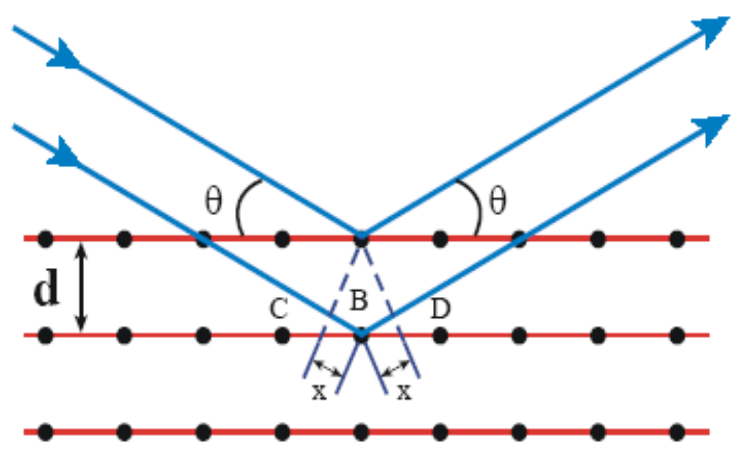

Figura 15 - llustração do fenômeno de difração de raios X - Lei de Bragg

Os ângulos $\theta$ dos raios $X$ refletidos estão relacionados com as dimensões das celas unitárias e as orientações dos planos interatômicos hkl específicos do material cristalino (REYNOLDS, 1989). Conseqüentemente, dois minerais com as mesmas dimensões de célula unitária produzem o mesmo padrão de reflexão de raios $\mathrm{X}$. Por outro lado, as intensidades relativas das várias reflexões hkl de um cristal, dentre outros fatores, são dependentes do número de elétrons no átomo. Adicionalmente, os átomos são distribuídos no espaço, de tal forma que vários planos de uma estrutura cristalina possuem diferentes densidades de átomos ou elétrons, fazendo com que as intensidades difratadas sejam, por conseqüência, distintas para os diversos planos cristalinos. Assim, cada composto cristalino apresenta um padrão de difração característico único, permitindo a sua identificação através das posições angulares e intensidades relativas dos feixes difratados.

\subsubsection{Instrumentos de detecção de raios $X$}

Os instrumentos de medida da difração de raios $X$ são os difratômetros com análises pelo método do pó ou com câmaras de monocristais acopladas, sendo que as últimas são utilizadas apenas em situações específicas, por exemplo, quando é crítica a disponibilidade de amostra e em estudos específicos para determinação de parâmetros cristalográficos (FORMOSO, 1984; JENKINS, 1989).

Nas câmaras de pó, um fino feixe de raios $X$ é focalizado sobre uma amostra posicionada no centro de um dispositivo cilíndrico, sendo que os feixes difratados sensibilizam um filme fotográfico posicionado internamente à câmara ou podem ser registrados por técnicas difratométricas, utilizando-se de um contador (detector) e equipamento eletrônico associado. Como ilustrado nas Figura 16 e Figura 17, o feixe 
de raios $\mathrm{X}$ difratado comporta-se como um cone com ápice na amostra e ângulo de abertura $4 \theta$, sendo simultaneamente registrados no filme fotográfico círculos concêntricos com aberturas correlacionáveis a $\theta \mathrm{e}$, portanto, às distâncias interplanares das fases componentes da amostra, através da lei de Bragg (FORMOSO, 1984).
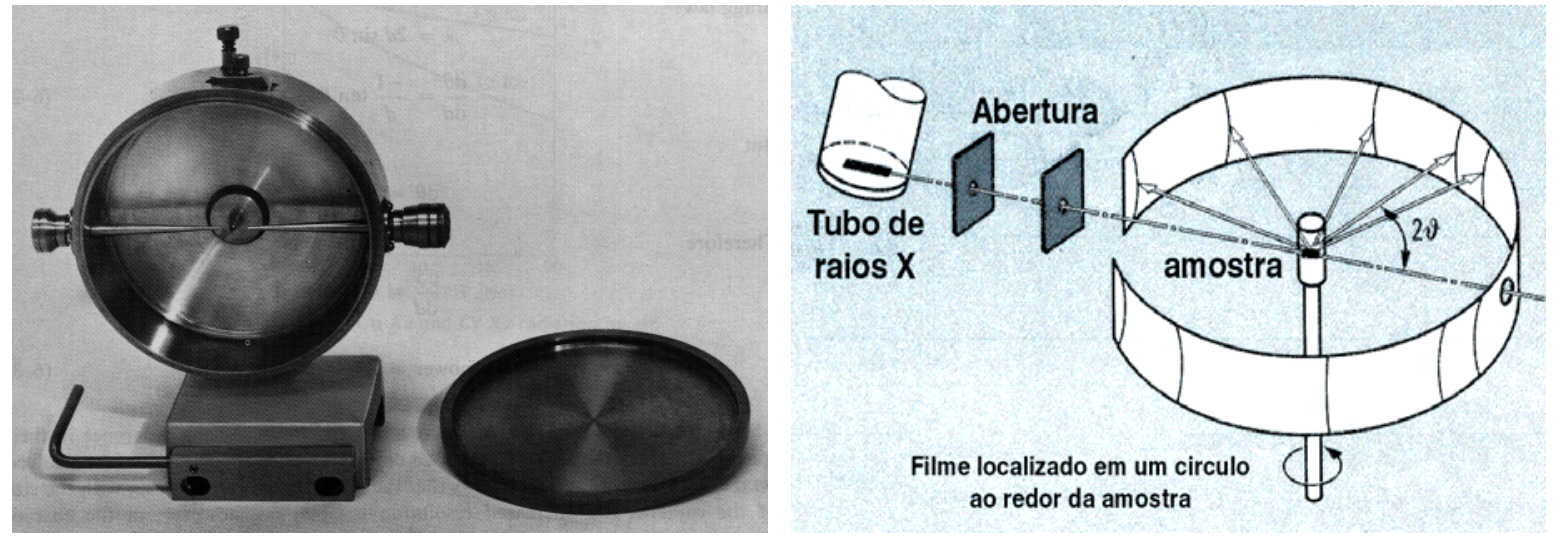

Figura 16 - Câmara de pó - Debye-Scherrer (CULLITY, 1978)

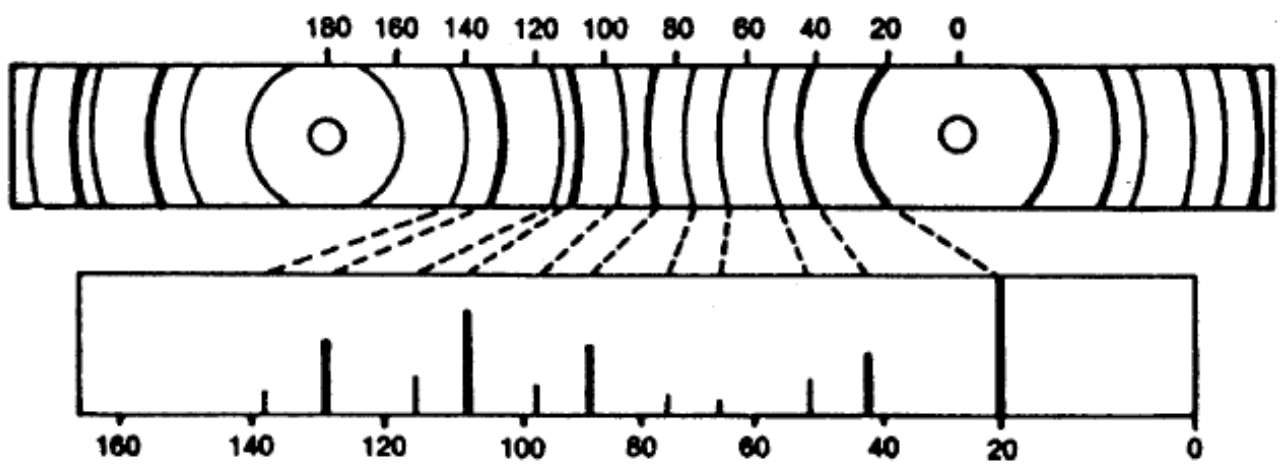

Figura 17 - Resultado da análise de difração de raios $X$ obtido pela câmara Debye-Scherrer (JENKINS, 1989)

Os difratômetros de raios X, segundo Jenkins (1989), foram originalmente configurados na denominada geometria parafocal Bragg-Brentano, onde seu arranjo geométrico básico constitui-se de um tubo de raios $X$, um goniômetro posicionado horizontal $(\theta-2 \theta)$ ou verticalmente $(\theta-2 \theta$ ou $\theta-\theta)$ e um detector de raios $X$.

Para a geometria $\theta-2 \theta$, como mostra a Figura 18 , o tubo gerador de raios $X$ (L) é fixado e o goniômetro move-se segundo o círculo $(\mathrm{H})$ com velocidade angular $(2 \theta / s)$ sobre o eixo (C) e movimenta a amostra $(P)$ com metade desta velocidade angular $(\theta / \mathrm{s})$. O raio do círculo do goniômetro é fixo, apresentando iguais distâncias 
do tubo gerador de raios $X$ à amostra $(L-P)$ e da amostra ao sistema de recepção ( $P$ D); entretanto, o raio do círculo focal varia com o ângulo, tendo seu valor máximo para $2 \theta=0^{\circ}$ e mínimo para $2 \theta=180^{\circ}$, sendo a superfície da amostra sempre tangencial ao círculo focal. $O$ plano do círculo focal contém os raios incidentes e difratados, isto é, a fonte de raios $X, a$ amostra e o sistema de recepção.

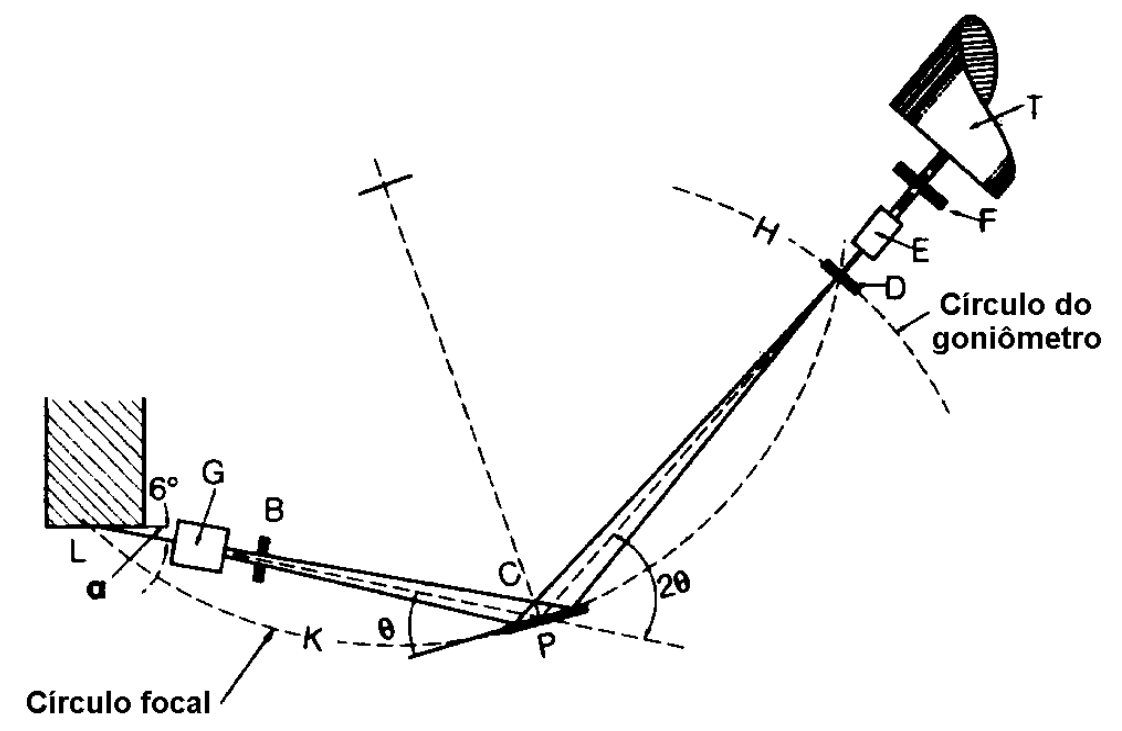

Figura 18 - Geometria Bragg-Brentano (adaptado de Jenkins, 1989)

Considerando que o feixe incidente e difratado são fontes pontuais de radiação (ondas esféricas de dispersão) e que a radiação incidente na amostra promove fenômenos de difração, espalhamento e fluorescência, um conjunto de fendas é inserido no sistema para minimizar as interferências e garantir a focalização das radiações difratadas de interesse à técnica.

A radiação incidente emitida pela fonte de raios $X(L)$ atravessa primeiramente a denominada fenda Soller ou colimadores paralelos (G) que controlam a divergência axial da radiação e, posteriormente, atravessa a fenda de divergência (B) que age na divergência lateral da radiação e, juntamente com a utilização de uma máscara, define a área da superfície da amostra que será irradiada $(P)$ (X'PERT, 2007).

A radiação difratada em determinados ângulos $2 \theta$ converge para a fenda de recepção (D) que capta a radiação proveniente unicamente da área irradiada da amostra, em direção ao detector $(\mathrm{T})$. Antes ou depois da fenda de recepção pode ser ainda colocado um segundo conjunto de colimadores paralelos $(E)$ e uma fenda 
de anti-espalhamento ou anti-dispersão $(F)$, excluindo toda radiação de fundo não proveniente da amostra ${ }^{1}$. Monocromador e filtros podem também ser colocados após a fenda de recepção com o intuito de se remover a radiação $K_{\beta}$ sem interesse e outras oriundas de espalhamentos não coerentes (radiação contínua); monocromadores auxiliam ainda na redução do background quando da existência de fluorescência em amostras com quantidades elevadas de Fe e Co, utilizando-se tubo de Cu, por exemplo (FORMOSO, 1984; JENKINS, 1989).

A Figura 19 ilustra mais detalhadamente as fendas utilizadas na geometria Bragg-Brentano e uma possível configuração geométrica de posicionamento das mesmas; a Figura 20 traz a disposição de um difratômetro clássico com geometria vertical $\theta-2 \theta$.

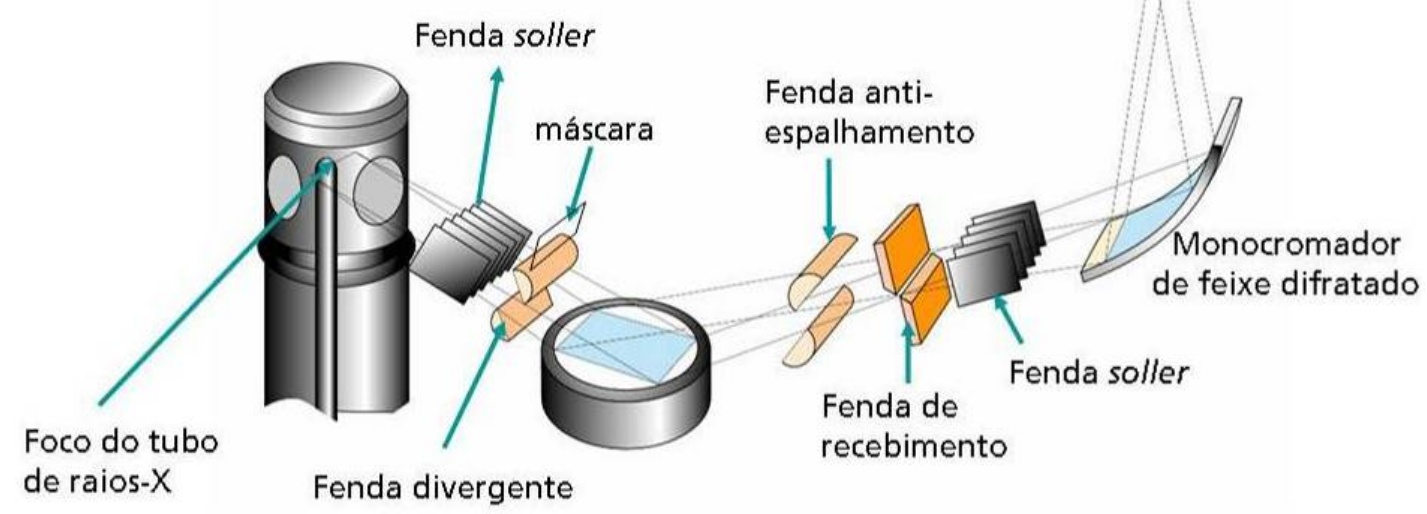

Figura 19 - Fendas na geometria Bragg-Brentano ${ }^{2}$

No caso de difratômetros configurados na geometria vertical $\theta-\theta$, como ilustrado na Figura 21, tanto o tubo gerador de raios $\mathrm{X}$ como o goniômetro movemse com velocidade angular (20/s) sobre o eixo perpendicular à amostra, a qual permanece fixa e horizontal durante todo o processo, podendo se movimentar apenas quando da utilização de spinners, sistema de rotação horizontal sobre o eixo da amostra. De maneira semelhante à configuração $\theta-2 \theta$, o raio do círculo do

\footnotetext{
${ }^{1}$ PHILIPS. Basic XRD theory. Netherlands: Philips Analytical, 1999. (Não publicado)

${ }^{2}$ PANalytical. Material de acesso interno. (Não publicado)
} 
goniômetro é fixo, o raio do círculo focal varia com o ângulo mantendo a superfície da amostra sempre tangencial ao círculo focal e o plano do círculo focal contém o raio incidente, a amostra e o raio difratado (X'PERT, 2007).

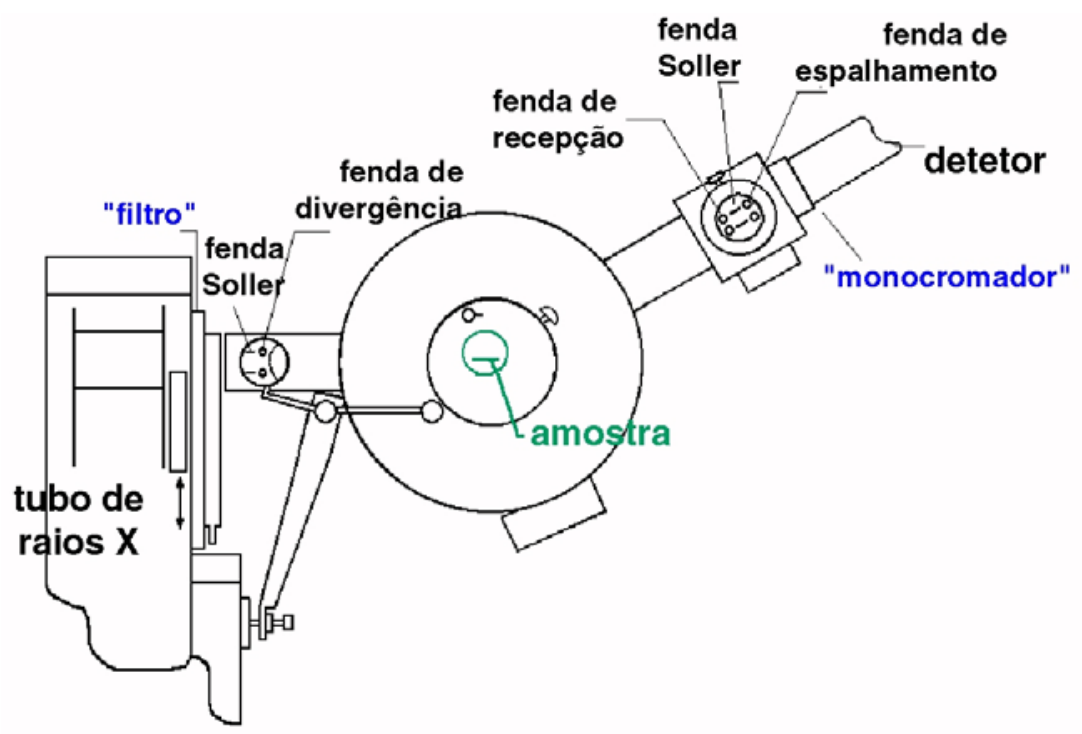

Figura 20 - Configuração $\theta-2 \theta$ de um difratômetro de raios $X$ - detector pontual ${ }^{3}$

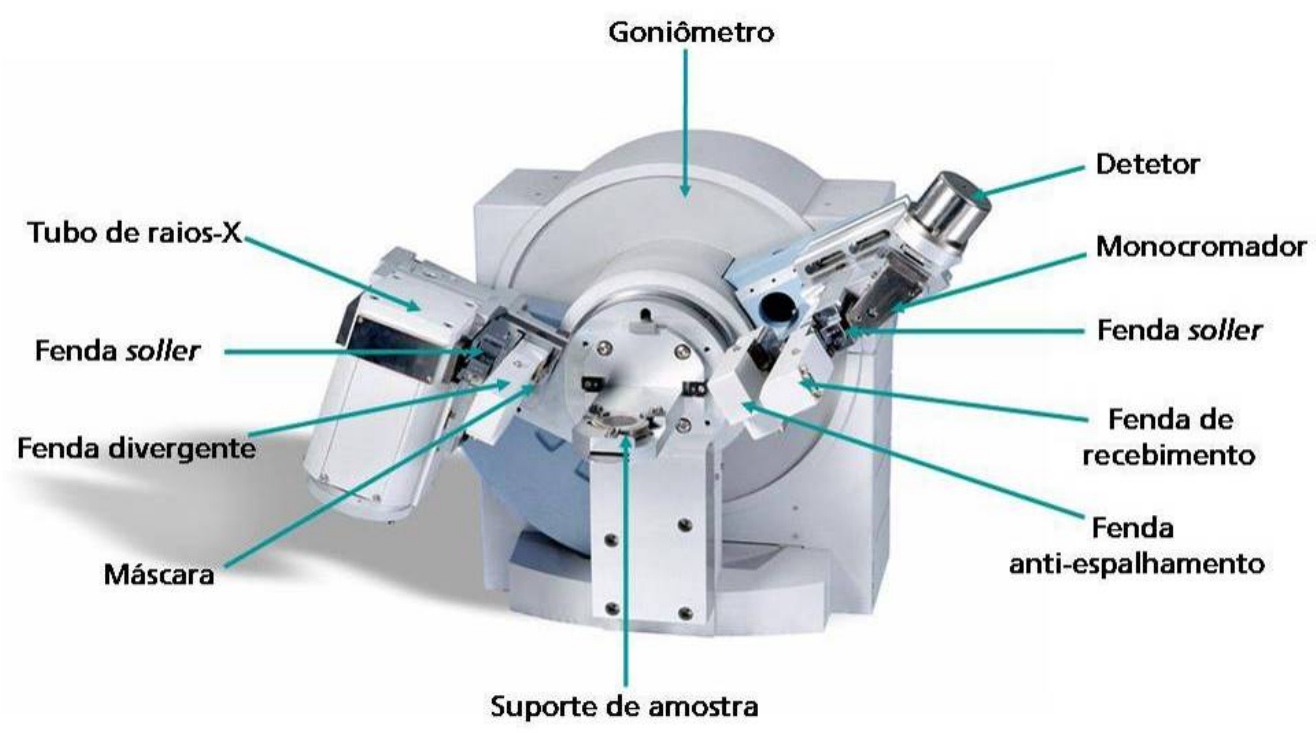

Figura 21 - Configuração $\theta-\theta$ de um difratômetro de raios $X^{4}$

Com relação ao sistema de detecção, sua função é converter fótons individuais de raios $X$ em pulsos de voltagem, que são contados e/ou integrados

\footnotetext{
${ }^{3}$ KAHN, H. Difração de raios X. São Paulo: Escola Politécnica, Universidade de São Paulo, 2000. 17 p. Curso apostilado. (Não publicado)

${ }^{4}$ PANalytical. Material de acesso interno. (Não publicado)
} 
pelo equipamento de contagem. Segundo Jenkins (1989), dentre os tipos de detectores utilizados em difratômetros convencionais, os denominados contadores de cintilação (pontual) ou proporcional selado (Xe) são geralmente utilizados. Vem destacando-se, porém, na última década, a introdução de detectores sensíveis à posição (linear), de alta velocidade de varredura. Um desses, por exemplo, emprega detectores de Si com uma tecnologia denominada RTMS (Real Time Multiple Strip), em que várias fendas de recepção funcionam simultaneamente. Com tal dispositivo, o tempo requerido para a análise de difração de raios $X$ fica drasticamente reduzido (1/100 do convencional), possibilitando maior difusão do emprego dessa técnica no setor mineral (GOBBO, 2009).

Como resultado, o feixe difratado detectado é geralmente expresso através de picos que se destacam do background (linha de base), registrados num gráfico de intensidade versus ângulo $2 \theta$ (ou d), constituindo-se o padrão difratométrico ou difratograma, exemplificado na Figura 22. Cada pico do difratograma representa a reflexão dos raios $X$ nos planos do retículo cristalino das fases componentes da amostra, cada qual com índices de Miller hkl (reflexões hkl), e apresenta uma determinada altura (intensidade), área, posição angular e com largura e caudas que decaem gradualmente à medida que se distanciam da posição de altura máxima do pico (FRONZAGLIA, 1999; GOBBO, 2003; JENKINS, 1989). Tais parâmetros físicos de determinado conjunto de picos refletem, portanto, características da estrutura cristalina das fases componentes de um material e estão intrinsecamente relacionadas às suas proporções relativas quando referentes às intensidades relativas entre conjunto de picos de distintas fases.

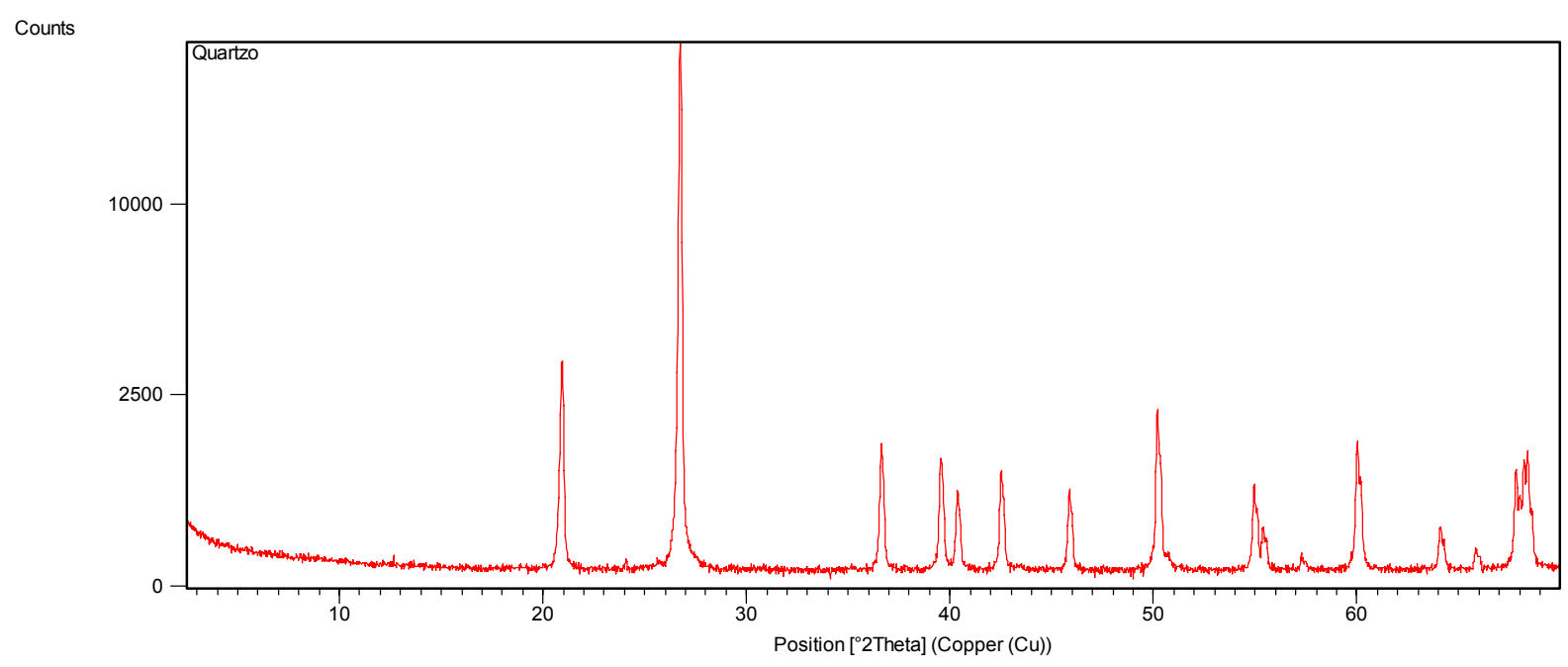

Figura 22 - Padrão difratométrico de uma amostra de quartzo 


\subsubsection{Fatores interferentes na intensidade, posição e perfil de picos}

Certas propriedades intrínsecas ao material, fatores geométricos instrumentais e outros relacionados à preparação de amostras podem influenciar na intensidade, posição e perfil dos picos de um perfil difratométrico. Tais aspectos são extremamente relevantes, tendo em vista, por exemplo, a importância da largura e a forma dos picos difratados na medida de tamanho de cristalitos e distorções de rede. O deslocamento de posição, por sua vez, é significante na determinação correta de espaçamentos interplanares, constantes reticulares ou mesmo tensão residual.

Esses fatores de interferência são vastamente discutidos por Klug e Alexander (1974) e são aqui sumariados para, ao menos, situar a problemática envolvida em modelos de análise quantitativa. Destaca-se que os fatores decorrentes de condições de difratômetro podem ser controlados por meio de configurações do equipamento e de sua calibração, assim como os desvios decorrentes de preparação de amostras podem ser minimizados.

\section{$\checkmark \quad$ Fatores intrínsecos à amostra}

Como citado anteriormente, a intensidade da difração é dependente da densidade de elétrons em um dado plano cristalino. Além desse fator, outras variáveis devem também ser consideradas.

O fator de multiplicidade $(p)$ refere-se à proporção relativa de planos que contribuem para a intensidade de um pico difratado. $O$ fator estrutura $(F)$ considera a eficiência do espalhamento pelos elétrons de um átomo e a posição dos mesmos na estrutura cristalina, também interferindo na intensidade dos picos (KLUG; ALEXANDER, 1974).

O fenômeno de absorção linear está relacionado à espessura da amostra, ao coeficiente de absorção de massa das fases, aos elementos químicos presentes e ao comprimento de onda da radiação utilizada. A profundidade de penetração do feixe na amostra (transparência) varia de acordo com a natureza do material, o comprimento de onda da radiação empregada e o ângulo de incidência.

Outro fator importante que interfere em um padrão difratométrico é a temperatura da amostra, que leva em conta as vibrações dos átomos em suas posições médias na cela unitária. Segundo Cullity (1978), a amplitude das vibrações 
aumenta com a elevação da temperatura, resultando em expansão da cela unitária com conseqüente modificação nas distâncias interplanares e, portanto, nas posições angulares dos picos difratados $(2 \theta)$; resulta ainda na diminuição das intensidades dos picos difratados e no aumento da intensidade de background.

A orientação preferencial corresponde à tendência dos cristalitos de apresentarem planos preferencialmente paralelos à superfície do porta-amostra, efeito comum aos compostos de hábitos tabulares, fibrosos e laminados. Isso resulta em maior freqüência na ocorrência desses planos e leva à alteração das intensidades relativas das reflexões dos vários planos (hkl).

Por fim, a presença de quantidades significativas de materiais amorfos modifica a linha de base (background) dos difratogramas, tornando-a não linear. Esse comportamento pode causar dificuldades na separação de picos pouco intensos, que não se destacam claramente do background (GOBBO, 2003).

\section{$\checkmark \quad$ Fatores instrumentais}

Os principais interferentes instrumentais estão relacionados ao desalinhamento de equipamento e ao uso de fendas e comprimento de onda inadequados; tais fatores são amplamente discutidos por Jenkins (1989), Jenkins e Snyder (1996) e Klug e Alexander (1974).

O zero do goniômetro é um valor determinado durante a calibração do equipamento de difração e a variação de sua posição deve situar-se abaixo de $0,02^{\circ}$ de $2 \theta$, visando reduzir os efeitos de deslocamento dos picos (constante para toda a faixa angular).

$A$ radiação $K_{\alpha}$ é formada pelo dubleto $K_{\alpha 1}$ e $K_{\alpha 2}$, as quais têm comprimentos de onda muito próximos e nem sempre são individualizadas em picos separados (especialmente em baixos ângulos), sendo responsáveis pela assimetria dos picos quando da decomposição do dubleto a ângulos mais altos.

O fator polarização (fator de Lorentz) refere-se a um fator geométrico que diminui as intensidades integradas dos picos difratados em ângulos intermediários (na faixa de $2 \theta$ entre 40 e $60^{\circ}$ ), quando comparados com os valores de ângulos menores e maiores, uma vez que a quantidade de polarização depende do ângulo através do qual a radiação é espalhada (CULLITY, 1978; FRONZAGLIA, 1999). 
A fenda de recepção afeta a intensidade e a resolução do perfil do pico difratado; intensidade e resolução ótimas são obtidas quando a largura do feixe é próxima da largura da fenda. Fendas mais estreitas aprimoram a resolução, porém comprometem as intensidades difratadas ${ }^{5}$.

A utilização de uma abertura maior na fenda de divergência para o feixe incidente resulta em aumento das intensidades dos picos, por outro lado, a restrição da incidência dos raios $X$ a partir de fendas estreitas, além de garantir que o portaamostra não seja iluminado, evita radiações de fundo a baixos ângulos de $2 \theta$. Fenda de divergência automática permite que se mantenha constante a área iluminada durante toda a análise e, segundo Gobbo (2009), promove background constante desde baixos a altos ângulos, enquanto que reflete picos com intensidades reduzidas a ângulos baixos comparativamente à fenda fixa.

O comprimento de onda utilizado na radiação deve ser adequado para o tipo de material a ser analisado (da ordem das distâncias entre os centros espalhadores - d) para que haja uma interferência construtiva que satisfaça a Lei de Bragg, bem como minimize efeitos de absorção de massa. A escolha inadequada do comprimento de onda pode ocasionar alterações no background, bem como perda de resolução e intensidade de picos de fases cristalinas que não condizem com tal comprimento de onda.

\section{$\checkmark$ Preparação de amostras}

Fatores relacionados à preparação de amostras são considerados as maiores fontes de erro para as três informações fundamentais de cada reflexão: posição angular, intensidade e perfil de pico.

A superfície da amostra, por exemplo, é um fator importante que garante a geometria parafocal Bragg-Brentano (BISH; REYNOLDS, 1989) e, idealmente, deveria ser curva ao longo do círculo focal dos raios incidentes. Como controle prático de reprodutibilidade na preparação de amostras, o melhor compromisso é a utilização de amostras planas horizontais. A fuga do ponto focal da óptica do

\footnotetext{
${ }^{5}$ PHILIPS. Basic XRD theory. Netherlands: Philips Analytical, 1999. (Não publicado)
} 
difratômetro pode ocasionar deslocamentos nas posições de picos e alargamento assimétrico dos perfis; assim, é necessário adequar a superfície das amostras ao nível / altura do porta-amostras a ser utilizado.

O efeito do tamanho das partículas foi discutido por Klug e Alexander (1974) que realizaram estudos em amostras de quartzo com diferentes distribuições de tamanho de partículas, entre 15 e $50 \mu \mathrm{m}, 5$ e $50 \mu \mathrm{m}, 5$ e $15 \mu \mathrm{m}$ e inferiores a $5 \mu \mathrm{m}$, obtendo desvios-padrão sobre 10 replicatas de cada fração, respectivamente, da ordem de $18,2 \%, 10,1 \%, 2,1 \%$ e $1,2 \%$. Concluíram que o erro aumenta paralelamente com a granulometria da amostra (BISH; REYNOLDS, 1989) por questões de estatística de grãos. Por outro lado, a moagem excessiva pode levar a alteração das dimensões cristalográficas dos cristais, influenciando no alargamento de picos e, conseqüentemente nos valores de $2 \theta$, além de eventual formação de fases amorfas.

Sendo quase impraticável cumprir a granulação idealmente definida, a solução prática para se garantir boa estatística na contagem das partículas, quando de granulação pouco acima de $10 \mu \mathrm{m}$, está na rotação da amostra durante a análise (spinning). Segundo Phillips ${ }^{6}$, amostras estacionárias com tamanho máximo de partículas de 5, 8 e $10 \mu \mathrm{m}$ promovem desvios de intensidade de 1, 2 e 3\%, respectivamente. No caso de amostras rotacionárias, a probabilidade de reflexão aumentaria em 60 vezes por partícula, passando o tamanho máximo de partículas para 18, 30 e $41 \mu \mathrm{m}$, considerando, respectivamente, os mesmos desvios anteriormente citados.

O fator orientação preferencial, característica intrínseca da amostra, pode ser intensificado na preparação da amostra durante a etapa de fixação (prensagem) da mesma ao porta-amostra. Segundo Jenkins e Snyder (1996), para minimizar tal efeito, podem ser adicionados à amostra materiais inertes e/ou amorfos que permitam o posicionamento aleatório dos cristais com orientação preferencial, possibilitando, assim, uma estatística de partículas mais próxima ao real, sem privilegiar/intensificar nenhuma das fases componentes. São ainda propostas maneiras de impedir o acomodamento das partículas utilizando-se colantes viscosos

\footnotetext{
${ }^{6}$ PHILIPS. Basic XRD theory. Netherlands: Philips Analytical, 1999. (Não publicado)
} 
ou mesmo a partir de borrifamento de amostra em pó atomizada sobre uma superfície (spray-drying), além da possibilidade de adições de padrão interno (FORMOSO, 1984).

Sabe-se que no momento da prensagem da amostra, a metodologia back loading pode também ser aplicada para a redução do efeito da orientação preferencial, sendo a prensagem efetuada pelo lado oposto à face da amostra que será efetivamente analisada, não interferindo tanto na disposição desses cristais. Destaca-se a existência de diversos tipos de porta-amostras aplicados a difratometria de raios $\mathrm{X}$, tais como os vazados para prensagem back loading com ou sem base de sustentação, sendo o último referente aos suportes tipo anel, além de finas lâminas de vidro onde o material é disposto entre duas delas, suportes de vidro e placas de silício para o acomodamento de pouca massa de amostra e ainda suportes como recipientes para amostras pastosas.

\subsubsection{Análise qualitativa por difração de raios $X$}

A principal aplicação da difração de raios $X$ tem se referido à identificação de compostos cristalinos, sejam eles inorgânicos ou orgânicos. Os planos de difração e suas respectivas distâncias interplanares, bem como as densidades de átomos (elétrons) ao longo de cada plano cristalino, são características específicas e únicas de cada substância cristalina, da mesma forma que o padrão difratométrico por ela gerado (equivalente a uma impressão digital).

A análise qualitativa de uma amostra é feita através da comparação de seu padrão difratométrico com padrões de referência, disponíveis em bancos de dados de difração de raios $X$. Bancos de dados contendo informações cristalográficas, tais como distâncias interplanares e as intensidades difratadas normalizadas (relativas a $100 \%$ ) para os vários planos hkl que difratam construtivamente os raios $\mathrm{X}$, além de algumas propriedades físicas de mais de 250.000 compostos cristalinos inorgânicos, são mantidos e continuamente atualizados pelo ICDD - International Centre for Diffraction Data, com sede nos EUA (JENKINS; SNYDER, 1996; ICDD, 2009), juntamente com organizações colaboradoras.

São várias as estratégias de identificação de fases que podem ser empregadas, sendo que a complexidade aumenta progressivamente com a elevação 
do número de fases cristalinas presentes na amostra. Os procedimentos de identificação manuais mais comuns referem-se à busca por compostos presumivelmente presentes em uma amostra e ao método de Hanawalt, aplicado para situações nas quais se desconhecem os compostos cristalinos presentes (JENKINS; SNYDER, 1996).

A partir da década de 90, sistemas automáticos de microcomputadores passaram a ser amplamente empregados no auxílio à identificação de fases cristalinas por difração de raios X. Nesse procedimento, os picos mais intensos de cada fase presente no banco de dados são comparados com o difratograma da amostra, atribuindo-se créditos/penalidades para cada pico difratado, no que se refere à presença/ausência de fases, intensidade difratada e deslocamento da distância interplanar. Ao final do processo de busca e comparação, os resultados são expressos em ordem decrescente de pontuação, seguindo-se a avaliação final por parte do usuário, como ilustrado na Figura 23 (REYNOLDS, 1989).

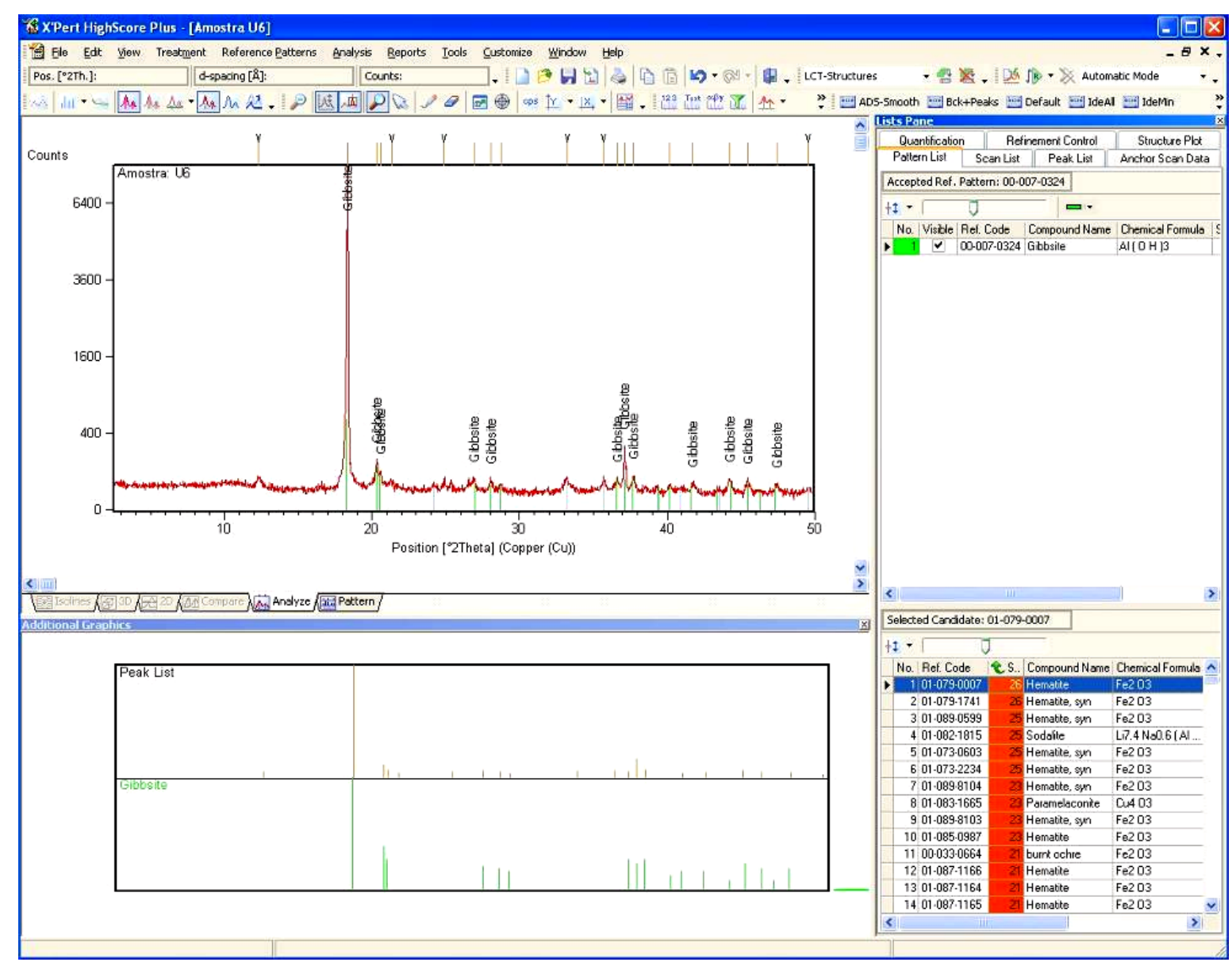

Figura 23 - Sistemas automáticos de identificação de fases (software High Score Plus da PANalytical), onde prováveis fichas de compostos são propostas 


\subsubsection{Análise quantitativa por difração de raios $X$}

Sabendo-se que a intensidade relativa de diferentes conjuntos de picos que representam as fases minerais relaciona-se à proporção das mesmas numa amostra, foram desenvolvidos diferentes métodos quantitativos de fases através da difração de raios $X$, tais como o método da adição, o método do padrão interno, curvas de calibração e método de Rietveld.

A quase totalidade destes métodos utiliza comparações com amostras de referência de proporções conhecidas das fases, que devem ser preparadas caso a caso. Adicionalmente, outros fatores como orientação preferencial, microabsorção e granulação da amostra propiciam substanciais dificuldades para se obter resultados quantitativos dentro de intervalos de precisão e exatidão aceitáveis, fazendo com que as técnicas de análises quantitativas por difração de raios $X$ sejam utilizadas em casos específicos.

Mais recentemente, com o desenvolvimento da tecnologia computacional, foi desenvolvida uma metodologia que permite o refinamento de estruturas cristalinas complexas, possibilitando a quantificação de fases por difração de raios $X$ a partir do método de Rietveld (RIETVELD, 1969). Esta metodologia permite que os vários interferentes no padrão difratométrico sejam considerados, compensados, corrigidos ou minimizados.

\subsubsection{O método de Rietveld}

Através do avanço da informática, com acesso a computadores mais potentes, o método de Rietveld, que tem por base a simulação de todo um perfil difratométrico partindo de parâmetros estruturais das fases componentes de uma amostra, permitiu que maiores informações pudessem ser extraídas dos difratogramas (RIETVELD, 1969; WILL, 2006).

O método desenvolvido por Hugo Rietveld aplicado à difração de raios $X$ tem por base a minimização da diferença entre um difratograma calculado e um 
experimental através do método de mínimos quadrados e permite a obtenção de resultados quantitativos das fases (GOBBO, 2003).

O termo refinamento pelo método de Rietveld refere-se ao processo de ajuste dos parâmetros utilizados na geração do padrão calculado para que seja o mais próximo do experimental, levando sempre em consideração a sobreposição dos picos de todas as fases presentes e as contribuições do ruído de fundo (background). Durante o refinamento, parâmetros denominados globais e específicos de cada fase constituinte e, por vezes, parâmetros instrumentais que afetam fisicamente os difratogramas, podem ser considerados, calculados e compensados, tais como (YOUNG, 2002):

Parâmetros individuais para cada fase:

- $x_{j} y_{j} z_{j} B_{j} N_{j}$

$\left(x_{j}, y_{j}, z_{j}\right.$, são posições atômicas, $B_{j}$ é o parâmetro termal isotrópico e $N_{j}$ é o multiplicador de ocupação do sítio, todos para o jésimo átomo na cela unitária)

- fator escala

- parâmetros de largura de perfil de picos (U, V e W)

- parâmetros de cela unitária

- fator temperatura total (B overall)

- parâmetro termal anisotrópico individual

- orientação preferencial

- tamanho de cristalitos e micro-tensões (parâmetros de perfil de pico)

- extinção

Parâmetros globais:

- zero do goniômetro (20-Zero)

- perfil instrumental

- assimetria do perfil

- linha de base ou background

- comprimento de onda

- deslocamento da amostra

- transparência da amostra

- absorção 
Post e Bish (1989) e McCusker et al. (1999) elaboraram guias de refinamento pelo método de Rietveld, nos quais são apresentadas as contribuições de cada um dos parâmetros de refinamento citados. A Figura 24 apresenta alguns exemplos de características dos difratogramas refinados geradas em função de fatores físicos, instrumentais ou preparação de amostra, segundo McCusker et al. (1999), permitindo através de análise visual identificar o tipo de parâmetro mais importante para cada etapa de refinamento. Para que o refinamento seja considerado satisfatório, a linha que representa o difratograma calculado deve se sobrepor à linha do difratograma observado, portanto, a linha de diferença deve se aproximar de uma reta.

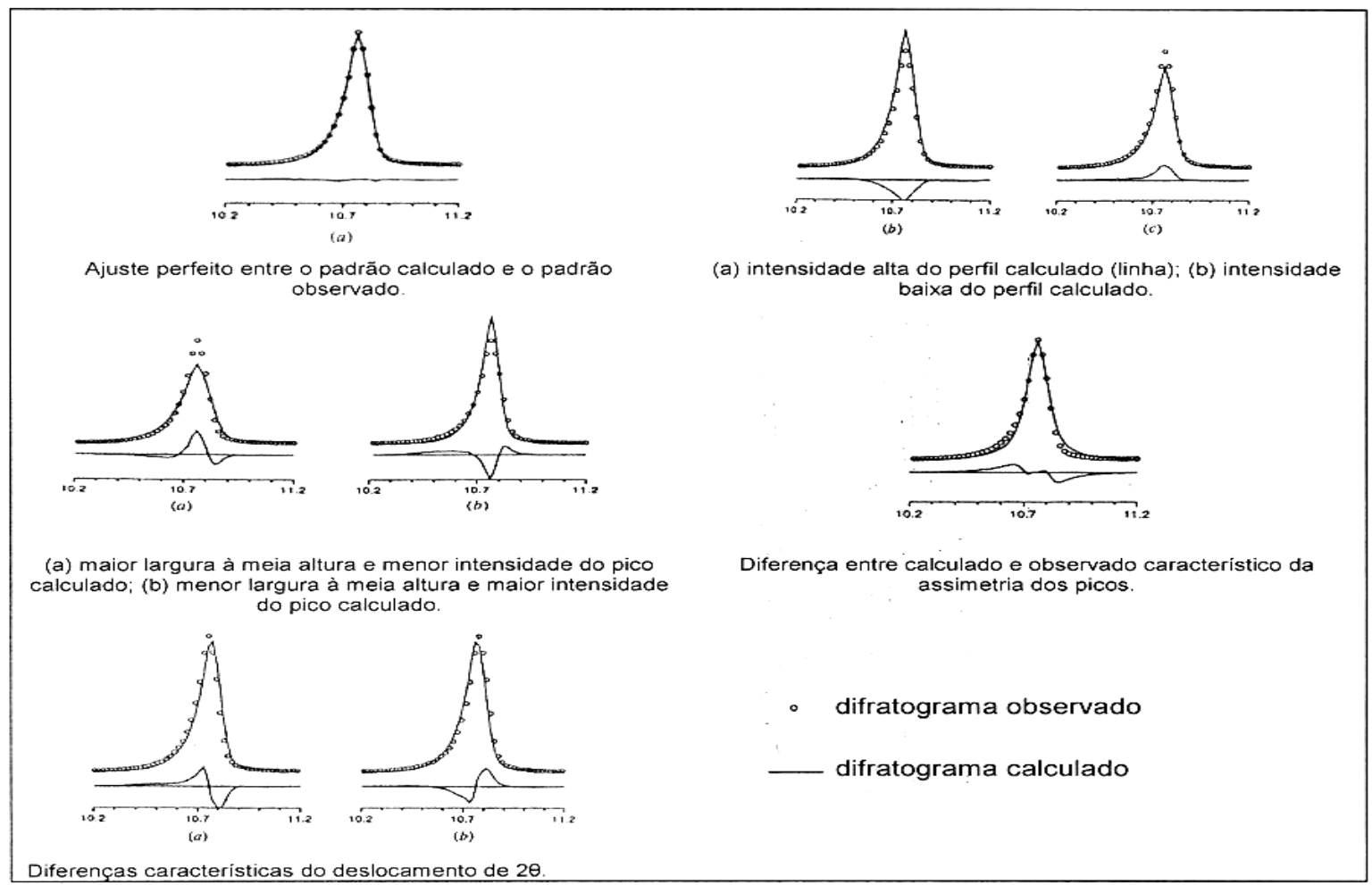

Figura 24 - Características de difratogramas refinados em função de fatores físicos, instrumentais ou de preparação de amostra, segundo McCusker et al. (1999)

A qualidade do refinamento é verificada através de indicadores estatísticos numéricos, que são utilizados durante o processo iterativo (cálculos) e após o término deste, para aferir se o refinamento está se procedendo de modo satisfatório.

Do ponto de vista matemático, $\mathrm{R}_{\mathrm{wp}}$ (R-weighted pattern) é um dos índices que melhor reflete o processo do refinamento por ter no numerador o resíduo que é minimizado; bons resultados fornecem valores de $R_{w p}$ da ordem de 2 a $10 \%$, porém 
tipicamente se encontram entre 10 e $20 \%$. O goodness-of-fit (GOF $=R_{w p} / R_{\text {exp }}$; exp = resíduo teórico mínimo esperado para o difratograma) é outro índice também freqüentemente utilizado e está relacionado à qualidade do ajuste entre o difratograma calculado e o observado; deve ser equivalente a 1,0 em um refinamento perfeito, sendo que na prática valores em torno de 5,0 caracterizam refinamentos otimizados (GOBBO, 2003, 2009; POST; BISH, 1989).

Alguns autores atentam para a influência do tempo de aquisição dos dados difratométricos sobre os parâmetros estatísticos (CALTABELOTI, 2006). Quando uma amostra é coletada em um tempo excessivo (alta resolução de dados), o valor de $R_{\exp }$ é muito pequeno e o GOF cresce substancialmente. Por outro lado, se a amostra é coletada em um tempo pequeno (baixa resolução de dados), o $R_{\text {exp }}$ será alto e, conseqüentemente, o GOF bastante baixo.

Post e Bish (1989) discutem outros indicadores estatísticos freqüentemente utilizados nos refinamentos através do método de Rietveld.

Atenta-se para a necessidade de uma adequada coleta do padrão difratométrico, sem desvios por interferências anteriormente discutidas (alinhamento e calibração instrumental, radiação e comprimento de onda adequados, preparação correta de amostra, uso de fendas apropriadas etc). Caso as intensidades relativas e/ou o valor de $2 \theta$ (d) obtidos num difratogramas não sejam reais, nenhum refinamento de estrutura fornecerá resultados acurados (MCCUSKER et al., 1999).

O conteúdo de material amorfo em uma amostra pode também ser determinado pelo método de Rietveld através da incorporação de uma quantidade conhecida de padrão interno (SPICER; VERRYN; DEYSEL, 2008).

Spicer; Verryn e Deysel (2008) destacam ainda a robustez do método de Rietveld considerando a aplicabilidade para amostras tanto homogêneas quanto heterogêneas, consideram a rapidez do método e a efetiva capacidade de distinção de fases, bem como a produção de dados quantitativos para as mesmas, possibilitando ainda o tratamento manual quando da sobreposição de picos e o desenvolvimento de programas de quantificação de amostras para refinamentos préestabelecidos, tendo em vista sua aplicação na indústria. 


\subsubsection{O método de Rietveld aplicado a bauxitas}

Por ser o foco de trabalho desta dissertação, destaca-se a problemática das características do minério de bauxitas na análise quantitativa por difração de raios $X$ com método de Rietveld.

A bauxita apresenta uma assembléia mineral com características de estrutura e cristalinidade peculiares para cada depósito (SANT'AGOSTINO; GOBBO; BRUMATTI, 2005). Argilominerais e gibbsita estão presentes em consideráveis proporções e possuem particularidades em termos de cristalinidade e de tamanho de cristalitos (granulometria muito fina, inferior a $2 \mu \mathrm{m}$ ), além de ampla capacidade de trocas catiônicas de elementos no caso dos argilominerais, com conseqüentes alterações no retículo cristalino (ANTONIASSI et al., 2007; PAIVA-SANTOS, 1989). Esses são fatores interferentes no padrão difratométrico das bauxitas, e portanto, na análise quantitativa por difração de raios $X$. Destaca-se ainda que tais minerais apresentam facilidades para geração de orientação preferencial no momento da preparação de amostras em função de suas características cristalográficas e hábito.

O parâmetro orientação preferencial gera um aumento significativo na intensidade de determinado conjunto de picos, não condizente com a real estrutura teórica de tais minerais, podendo ocasionar uma quantificação incorreta se não cuidadosamente considerada e compensada. Um método foi proposto para controlar a orientação preferencial da caulinita empregando misturas do argilomineral com substâncias orgânicas em pó (BRINDLEY; KURTOSSY, 1961, apud DIXON, 1977).

Post e Bish (1989) apresentam também a idéia de que polimorfos de argilominerais nas bauxitas, tais como dickita, nacrita (BÜHMANN, 1988) e haloisita (argilominerais do grupo da caulinita), que se assemelham estruturalmente com a caulinita, contribuem em suas intensidades difratadas; caso essas impurezas não sejam detectadas na etapa de identificação de fases, certamente prejudicarão a qualidade do refinamento.

Aylmore e Walker (1998) e Kirwan et al. (2009), assim como Li et al. (2006) e Nong et al. (2007), destacam as freqüentes substituições isomórficas entre $\mathrm{Al}^{3+} \mathrm{e}$ $\mathrm{Fe}^{3+}$ nos minerais goethita, hematita e bohemita, e descrevem a possibilidade de refinamento de tais variações a partir de parâmetros de célula unitárias e sítios de 
ocupação atômica. Entretanto, demonstram que análises quantitativas obtidas através do método de Rietveld são adequadas a bauxitas lateríticas, desde que se atente para características composicionais e aspectos físicos das fases individuais componentes; alguns comparam tal metodologia com quantificações mineralógicas obtidas por outras técnicas (FRX), obtendo-se elevados fatores de correlação. Por fim, demonstram que o método de Rietveld permite considerar e compensar características particulares das bauxitas, tais como substituições isomórficas, cristalinidade, tamanho de cristalitos e orientação preferencial, as quais podem fornecer informações sobre gênese de solos, delineação de reservas e de comportamento de minerais frente às operações de processamento de alumina no processo Bayer.

\subsection{Técnicas complementares ao trabalho}

Algumas técnicas relevantes e que foram aplicadas complementarmente no decorrer desta dissertação são sumariamente descritas a seguir.

\subsubsection{Espectroscopia por fluorescência de raios $X$}

A espectrometria por fluorescência de raios $X(F R X)$ é um método analítico para a determinação da composição química de materiais em geral, sólidos, líquidos e gases, passando cada vez mais a desempenhar papel marcante especificamente na geoquímica de minerais e rochas (DUTRA; GOMES, 1984).

A técnica baseia-se na irradiação e excitação de uma dada substância por meio de um feixe de raios $X$, emanado de um tubo operado em condições de alta voltagem, trazendo como resultado a produção de uma radiação secundária (fluorescente), característica dos elementos químicos presentes em uma amostra. Conhecendo-se os ângulos de reflexão e as intensidades dessa radiação, é possível, a partir de cristais analisadores e detectores específicos, a determinação qualitativa e quantitativa de todos os elementos constituintes. Os detectores captam a radiação fluorescente característica do átomo que a emitiu e conseguem distinguir diferentes radiações características pelas suas energias.

Utilizando-se um detector de dispersão de energia (EDS - Energy Dispersive Spectrometer; geralmente o Si) todo o espectro elementar é captado 
simultaneamente, enquanto que a partir de um detector de dispersão de comprimento de onda (WDS - Wavelengh Dispersive Spectrometer) são captadas as linhas características individualizadas pelo(s) cristal(is) analisador(ES) ${ }^{7}$. Ambos os procedimentos são adequados para análises qualitativas de elementos, e para as quantitativas, diferindo em resolução / sensibilidade: o primeiro com capacidade para determinações de teores de 0,1 a 100\%, e o segundo para teores da ordem de dezenas a centenas de partes por milhão (> 0,01\%) (RATTI, 1994; SANT'AGOSTINO, 1996).

A técnica espectrometria por fluorescência de raios $X$ cobre praticamente todos os elementos da tabela periódica, desde o berílio até o urânio.

Jenkins (1988) discute detalhadamente esta técnica.

\subsubsection{Método de estimativa mineral apoiado em análises químicas}

Esta tradicional prática de estimativa mineralógica baseada na conjugação de composições químicas minerais teóricas com análises químicas totais, desde que se conheça previamente a assembléia mineral componente de determinado material, apresenta aceitável confiabilidade em estudos de caracterização de materiais e em várias áreas de pesquisa. Cálculos estequiométricos alocam e assumem determinados elementos na computação de determinados minerais, obtendo-se os resultados quantitativos das fases (RESENDE; BAHIA FILHO; BRAGA, 1987; JONES, 1987).

O exemplo aplicável a este trabalho refere-se a bauxitas, que possuem assembléia mineralógica relativamente simples e que apresentam como maiores constituintes hidróxidos de alumínio (gibbsita - $\left.\mathrm{Al}(\mathrm{OH})_{3}\right)$, argilominerais (caulinita $\mathrm{Al}_{2} \mathrm{Si}_{2} \mathrm{O}_{5}(\mathrm{OH})_{4}$ ), óxi-hidróxidos de ferro (hematita - $\mathrm{Fe}_{2} \mathrm{O}_{3}$ e goethita - $\mathrm{FeO}(\mathrm{OH})$ ) e, mais raramente, óxidos de titânio (anatásio e rutilo - $\left.\mathrm{TiO}_{2}\right)$, quartzo $\left(\mathrm{SiO}_{2}\right)$ e outros. Assim, são dosados teores totais de $\mathrm{Al}_{2} \mathrm{O}_{3}, \mathrm{SiO}_{2}, \mathrm{Fe}_{2} \mathrm{O}_{3}$ e $\mathrm{TiO}_{2}$ para a realização das

${ }^{7}$ RATTI, G. XIV Curso de fluorescência de raios X. São Paulo: Laboratório de Caracterização Tecnológica - Escola Politécnica, Universidade de São Paulo, 2008. 63 p. Material de Curso de Difusão. (Não publicado) 
ponderações estequiométricas, além de análises químicas específicas para bauxitas que fornecem conteúdos de $\mathrm{Al}_{2} \mathrm{O}_{3}$ aproveitável e $\mathrm{SiO}_{2}$ reativa e permitem que a estimativa mineralógica tradicional seja computada da seguinte forma:

- $\mathrm{Al}_{2} \mathrm{O}_{3}$ aproveitável estaria relacionada à gibbsita;

- $\mathrm{SiO}_{2}$ reativa estaria relacionada à caulinita;

- óxi-hidróxidos de ferro assumiriam teores de $\mathrm{Fe}_{2} \mathrm{O}_{3}$;

- óxidos de titânio seriam calculados pelo $\mathrm{TiO}_{2}$;

- quartzo estaria relacionado a sílica não reativa $\left(\mathrm{SiO}_{2}\right.$ total - $\mathrm{SiO}_{2}$ reativa).

Sabe-se que em muitos casos de estimativa mineral através de cálculos estequiométricos, apenas a disponibilidade de dados químicos totais não é suficientes para permitir a estimativa mineral completa, visto que muitos minerais, com distintas composições teóricas, possuem similaridade de elementos químicos que os compõem, tornando-se impraticável assumir determinados elementos para as quantificações de determinados minerais. No caso das bauxitas, sem a disponibilidade das análises específicas de $\mathrm{Al}_{2} \mathrm{O}_{3}$ aproveitável e $\mathrm{SiO}_{2}$ reativa, a estimativa mineral é comprometida, visto que ambos os minerais gibbsita e caulinita apresentam Al em suas composições. Além disso, a caulinita não poderia ser diretamente dosada pelo Si devido à presença do quartzo, e vice-versa.

Além de dosagens químicas específicas, outras técnicas complementares podem contornar essas dificuldades (limitação dessa metodologia) na estimativa das fases, tais como ensaios de separações minerais, que concentram menor número de espécies em determinados produtos, simplificando assim sua estimativa por análises químicas, além de análises termodiferenciais e termogravimétricas DTA/TG (BOSKI; PAEPE, 1988; ALVES; MASCARENHAS; VAZ, 2008), que permitem a imediata quantificação de parte das fases minerais facilitando a estimativa das demais.

Apesar da possibilidade de se contornar as limitações citadas, deve-se atentar para questões de substituições elementares que podem ocorrem dentro da estrutura cristalina de minerais, alterando suas composições teóricas. Boski e Paepe (1988) citam que a goethita pode apresentar mais $\mathrm{H}_{2} \mathrm{O}$ em sua estrutura real do que na teórica idealizada, assim como Santos; Costa e Schuckmann (1997) tratam de 
substituições isomórficas de Fe-Al na estrutura dos minerais goethita e hematita; o alumínio incorporado à estrutura de minerais ferruginosos não é dissolvido durante o tratamento industrial das bauxitas, não sendo recuperado pelo processo Bayer de produção de alumina.

Destaca-se, portanto, que tais limitações assim como erros analíticos podem acarretar alguns desvios na estimativa mineral final e, conseqüentemente, interferir na avaliação de minérios frente a processos (ISOITKO, 1990).

\subsubsection{Microscopia eletrônica de varredura}

A técnica de microscopia eletrônica de varredura (MEV / SEM - Scanning Electron Microscopy) baseia-se no fenômeno de interação entre um feixe de elétrons e a amostra a ser analisada (GOLDSTEIN et al., 2003).

Ao atingir a amostra, o feixe de elétrons excita certo volume da mesma, sendo que dessa interação elétrons-amostra alguns tipos de elétrons (secundários e retroespalhados), além de raios $X$ característicos e catodoluminescência, são emitidos, podendo ser captados por diferentes detectores posicionados em pontos estratégicos dentro da câmara de amostras.

Os elétrons secundários são emitidos bem próximos à superfície da amostra e permitem justamente observações da superfície da mesma, oferecendo detalhes da sua morfologia e textura e proporcionando informações de caráter tridimensional. Os elétrons retro-espalhados são emitidos aproximadamente do centro do volume de interação e fornecem imagens que individualizam fases a partir das variações em suas composições químicas, através de diferentes tons de cinza gerados em função do número atômico médio das fases, onde áreas mais claras indicam presença de elementos químicos com número atômico mais elevado.

Da porção mais profunda do volume de interação são emitidos os raios $X$ característicos, que permitem a identificação e quantificação dos elementos químicos presentes na porção da amostra que está sendo excitada, com base em espectrômetros de raios X por EDS ou WDS.

Cada elemento químico presente no volume de amostra analisado gera um conjunto de picos característicos, sendo possível a determinação qualitativa e quantitativa de todos os elementos nele constituintes (GOLDSTEIN et al., 2003). 
A técnica corresponde a uma importante ferramenta analítica de escala milimétrica a nanométrica.

\subsubsection{Método estatístico de análise por agrupamento}

A análise por agrupamento (cluster analysis) é uma ferramenta estatística multivariada de análise exploratória, que visa a ordenar uma coleção de dados em grupos de semelhança e dissimilaridades, de maneira que o grau de similaridade entre dois objetos seja máximo quando pertencentes ao mesmo grupo e mínimo quando pertencentes a grupos diferentes, não exigindo, porém, necessidade de conhecimento prévio dos mesmos para tal ordenação (X'PERT, 2008; ELETRONIC, 2008).

$\mathrm{Na}$ técnica são considerados algoritmos e critérios matemáticos (matrizes de correlação) que originam as categorias de agrupamentos, sendo esses parâmetros escolhidos pelo operador e geralmente aplicados ao método de análise por agrupamento denominado aglomerativo hierárquico (ANTONIASSI, 2006). Nesse método assume-se que inicialmente todos os dados são individuais, sendo combinados progressivamente em grupos de semelhança até que, por fim, todos os dados se juntem em um único grupo, como ilustrado na Figura 25 (DAVIS, 1986; MANLY, 1994).
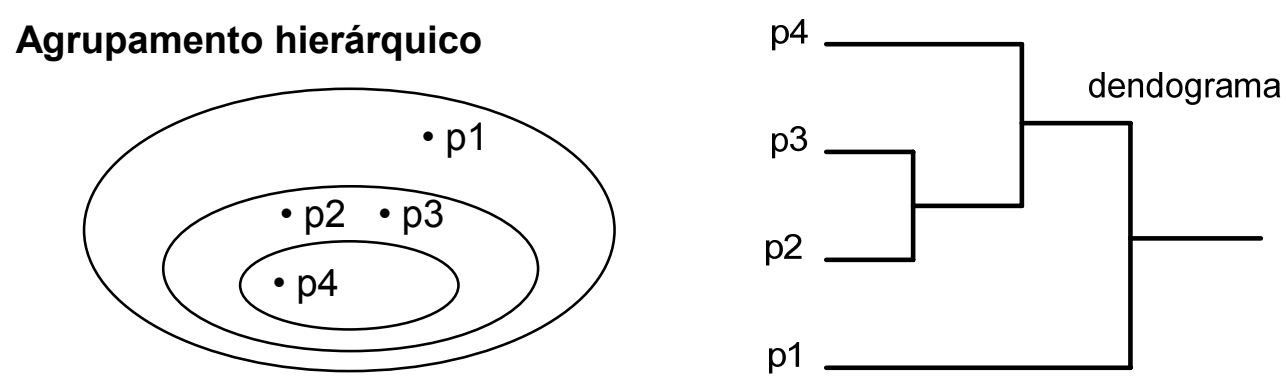

Figura 25 - Análise por agrupamento hierárquico (TAN; STEINBACH; KUMAR, 2005)

O resultado do agrupamento pode ser expresso por dendogramas, uma representação gráfica da determinação matemática de comparação de dados, onde em um dos eixos é plotada a distância das ligações de pares de dados (menores distâncias referem-se às maiores similaridades) e no outro são agrupados os indivíduos analisados. 
O recurso de análise por agrupamento corresponde a uma ferramenta adicional para classificação de materiais geológicos através da associação de diferentes amostras em grupos de semelhança. A técnica simplifica consideravelmente a análise individual de grande número de amostras ${ }^{8}$, as determinações sistemáticas e quantitativas de elementos e/ou minerais, bem como estudos de formas de associações em um corpo de minério, empregados em auxílio à exploração, lavra (blendagens), processos de beneficiamento (liberação / associação mineral), além de estudos de gênese e controles de mineralização (ANTONIASSI et al., 2008).

A análise por agrupamento, além de se constituir em recurso adequado para o tratamento e classificação de dados de análises químicas, pode atualmente ser aplicada para agrupar padrões difratométricos. Paralelamente, a difratometria de raios $X$ através do método do pó, com o advento da introdução de detectores sensíveis à posição, propiciou a coleta de difratogramas em tempo reduzido (poucos minutos), possibilitando maior difusão do emprego desta técnica no setor mineral. Seu potencial de aplicação em substituição ou complementação à utilização da composição química no estabelecimento de agrupamento de amostras foi substancialmente ampliado mediante a realização de análises mineralógicas rotineiras e aplicação destes resultados em estudos de classificação e predição do comportamento de tipos de minério nos processos de beneficiamento (ANTONIASSI et al., 2008).

Aplicando-se a ferramenta de difração de raios $X$ com recursos de cluster analysis a partir do software X'Pert High Score Plus, marca PANalytical, pode-se processar diretamente inúmeros difratogramas de raios $\mathrm{X}$, sem o prévio tratamento dos mesmos ou identificação/conhecimento das assembléias mineralógicas presentes. O procedimento de classificação pode considerar tanto a posição de picos difratados quanto as intensidades difratadas, sendo que os agrupamentos resultantes retratam não só variações de assembléias mineralógicas como do conteúdo dos minerais presentes, apontando ainda materiais de grande

\footnotetext{
${ }^{8}$ MARCCHIAROLA, K. et al. Modern x-ray diffraction techniques for exploration and analysis of ore bodies. Apresentado ao $7^{\text {th }}$ International Conference on Mineral Exploration, Otawa, 2008. (Não publicado)
} 
representatividade dentre os grupos, bem como padrões difratométricos anômalos, que não se encaixam entre as classes definidas ${ }^{9}$.

\subsubsection{Espectroscopia Mössbauer}

A espectroscopia Mössbauer (EM) é uma técnica ressonante que utiliza o fato de que um fóton gama $(\gamma)$ pode ser emitido por um núcleo excitado e absorvido por outro núcleo sem perda de energia, desde que o segundo esteja incorporado a uma matriz sólida. Assim, um espectro Mössbauer consiste num gráfico de número de fótons gama absorvidos / transmitidos em função da velocidade da fonte em relação ao alvo (JORGE, 2005; WERTHEIEM, 1964).

O nuclídeo mais favorável para a observação do efeito Mössbauer é o ${ }^{57} \mathrm{Fe}$ que é um constituinte comum em variados compostos. O espectro de um composto puro de Fe pode apresentar uma única linha de ressonância (singleto), duas linhas (dubleto) ou seis linhas (sexteto magnético, conforme Figura 26).

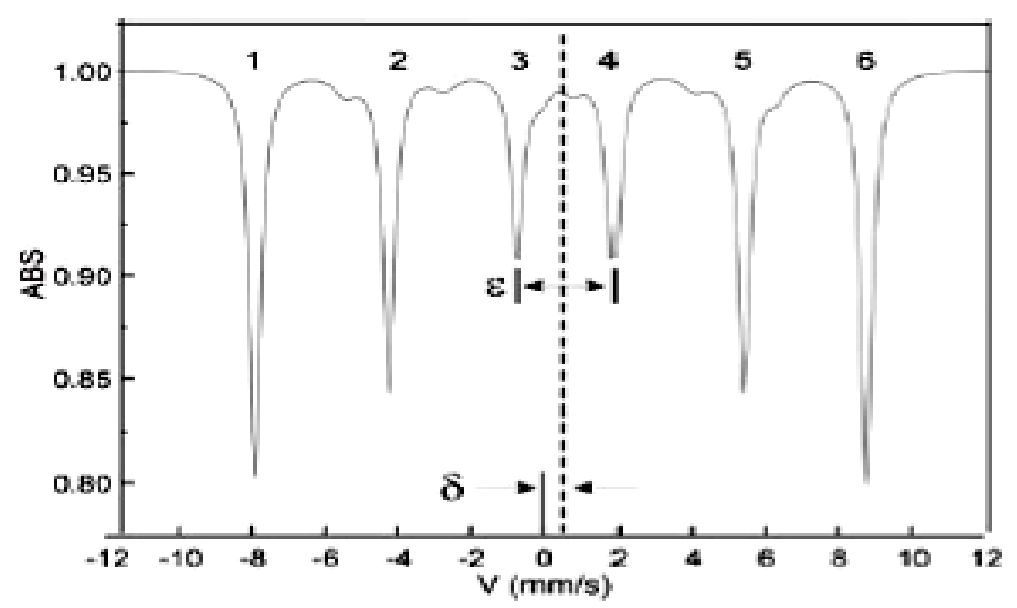

Figura 26 - Espectro de um composto de ferro apresentando um sexteto. São apresentados o deslocamento isométrico $(\delta)$ e o desdobramento quadrupolar $(\varepsilon)$ (WERTHEIEM, 1964)

A interação do feixe gama incidente e núcleos atômicos da amostra corresponde a uma interação hiperfina, definida por pequenas energias de

\footnotetext{
${ }^{9}$ MARCCHIAROLA, K. et al. Modern x-ray diffraction techniques for exploration and analysis of ore bodies. Apresentado ao $7^{\text {th }}$ International Conference on Mineral Exploration, Otawa, 2008. (Não publicado)
} 
deslocamentos e desdobramentos de níveis nucleares que podem ser medidas. Alguns dos parâmetros das interações possíveis de serem determinados são:

- campo hiperfino: grandeza relacionada com o momento magnético do átomo de ferro no material estudado;

- largura de linha espectral: relacionada à incerteza na energia, definida pelo princípio de incerteza de Heisenberg;

- absorção: representada pela altura relativa da linha, a qual varia conforme a proporção de um determinado composto que contenha em sua formulação química o nuclídeo de Mössbauer utilizado;

- deslocamento isomérico: relacionado com o estado de oxidação ou valência dos átomos que compõem a amostra;

- desdobramento quadrupolar: relacionado com a simetria local, sendo nulo no caso de simetria cúbica.

A Tabela 2 mostra os parâmetros Mössbauer utilizados na identificação dos compostos de ferro mais comuns.

Tabela 2 - Parâmetros Mössbauer de óx-hidr. de ferro com estrutura ideal para 297K (Bhf= campo magnético hiperfino; $\delta=$ deslocamento isométrico; $\varepsilon=$ desdobramento quadrupolar)

\begin{tabular}{|l|c|c|c|}
\hline Mineral / Fórmula química & $\mathrm{B}_{\mathrm{hf}}(\mathrm{T})$ & $\delta(\mathrm{mm} / \mathrm{s})$ & $\varepsilon(\mathrm{mm} / \mathrm{s})$ \\
\hline Hematita / $\mathrm{Fe}_{2} \mathrm{O}_{3}$ & 51,7 & 0,37 & $-0,20$ \\
Magnetita / $\mathrm{Fe}_{3} \mathrm{O}_{4}$ & 49,0 & 0,26 & $-0,02$ \\
Goethita / FeOOH & 38,2 & 0,37 & $-0,26$ \\
\hline
\end{tabular}

Da técnica são extraídas informações extremamente relevantes em estudos mineralógicos, relacionadas a ligações químicas (estados de oxidação e spin) e estruturas moleculares de compostos, sendo possível a determinação qualitativa e quantitativa das fases minerais portadoras de ferro constituintes de uma amostra (JORGE, 2005).

A técnica permite ainda a investigação de espécies mal cristalizadas ou amorfas e até mesmo identificar a presença de dimensões muito pequenas de grãos, o que atua no valor do campo hiperfino e, conseqüentemente, na forma do espectro Mössbauer. 
Cromphaut et al. (2008), Kirwan et al. (2009), Murad (2004) e Raj; Harchand e Maini (1993) apresentam a utilização da técnica de espectroscopia Mössbauer em estudos específicos de caracterização de bauxitas, onde geralmente são observadas hematita e goethita como fases portadoras de Fe. A primeira apresenta-se na forma de um sexteto bem definido, enquanto que a segunda mostra-se como um sexteto largo. Destacam geralmente a baixa cristalinidade e/ou substituições de Al nas estruturas cristalinas da hematita e goethita. Por fim, apontam a existência de um dubleto relacionado a uma forma paramagnética, possivelmente goethita de cristalinidade comprometida (limonita?), com tamanhos de cristais muito pequenos e possibilidade de substituições isomórficas. 


\section{MATERIAIS E MÉTODOS}

\subsection{Amostras estudadas}

As amostras de bauxitas estudadas foram coletadas e fornecidas pela MRN juntamente com seus dados de análises químicas, conforme a Tabela 3. Apresentavam cerca de $1,5 \mathrm{~kg}$ cada, granulometria variando entre 5 e $20 \mathrm{~mm}$ e correspondiam a:

- 30 amostras da pesquisa mineral, identificadas por P1 a P30, relativas a testemunhos de furos de sondagens;

- 30 amostras produtos de etapas de beneficiamento, identificadas por U1 a U30.

Tabela 3 - Composição química das amostras estudadas

\begin{tabular}{|c|c|c|c|c|c|c|c|c|c|c|c|c|}
\hline \multirow{2}{*}{$\mathrm{n}^{\circ}$} & \multicolumn{6}{|c|}{ Amostras $\mathbf{P}$ (pesquisa) } & \multicolumn{6}{|c|}{ Amostras U (beneficiamento) } \\
\hline & $\mathrm{Al}_{2} \mathrm{O}_{3}$ & $\mathrm{SiO}_{2}$ & $\mathrm{Fe}_{2} \mathrm{O}_{3}$ & $\mathrm{TiO}_{2}$ & $\mathrm{Al}_{2} \mathrm{O}_{3}$ ap & $\mathrm{SiO}_{2} \mathrm{re}$ & $\mathrm{Al}_{2} \mathrm{O}_{3}$ & $\mathrm{SiO}_{2}$ & $\mathrm{Fe}_{2} \mathrm{O}_{3}$ & $\mathrm{TiO}_{2}$ & $\mathrm{Al}_{2} \mathrm{O}_{3} \mathrm{ap}$ & $\mathrm{SiO}_{2} \mathrm{re}$ \\
\hline 01 & 56,1 & 2,27 & 12,5 & 1,45 & 51,7 & 1,85 & 54,4 & 5,05 & 10,6 & 1,59 & 48,5 & 4,41 \\
\hline 02 & 52,7 & 1,87 & 14,8 & 1,90 & 51,3 & 1,47 & 54,9 & 5,00 & 8,90 & 1,65 & 49,3 & 4,36 \\
\hline 03 & 55,7 & 1,33 & 12,1 & 1,90 & 54,1 & 1,02 & 55,9 & 5,81 & 8,28 & 1,53 & 48,9 & 4,68 \\
\hline 04 & 56,2 & 3,22 & 9,56 & 1,93 & 52,9 & 2,66 & 55,6 & 4,85 & 9,78 & 1,58 & 49,3 & 4,63 \\
\hline 05 & 55,3 & 2,13 & 11,6 & 1,69 & 53,5 & 1,55 & 54,8 & 5,73 & 9,68 & 1,62 & 47,9 & 5,65 \\
\hline 06 & 55,4 & 1,80 & 10,4 & 1,84 & 54,7 & 1,42 & 53,6 & & 0,8 & 1,58 & 48,4 & 4,94 \\
\hline 07 & 55,0 & 3,51 & 9,87 & 2,07 & 52,5 & 2,66 & 56,0 & 5 & 9,75 & 1,55 & 48,9 & 4,58 \\
\hline 08 & 51,1 & 10,0 & 10,2 & 2,04 & 42 , & 8,13 & 55,5 & & 40 & 1 & 48,9 & 4,16 \\
\hline 09 & 50,6 & 15,5 & 7,64 & 2,14 & 35 & 15,2 & 53,4 & & 1 & 1 & 48,1 & 4,69 \\
\hline 10 & 47,9 & 22,4 & 4,24 & 1,92 & 25 & 24,2 & 55,7 & 5, & 0 & 1 & 4 & 5,02 \\
\hline 11 & 45,7 & 25,9 & 5,75 & 1,93 & 21,0 & 26,5 & 53,9 & 5 , & 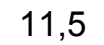 & 1, & 4 & 5,37 \\
\hline 12 & 45,2 & 28,7 & 5,04 & 2,06 & 10,3 & 29,5 & 54,2 & 5 , & 5 & 1,48 & 47,7 & 4,45 \\
\hline 13 & 48,0 & 21,0 & 6,51 & 2,1 & 27,9 & 21,7 & 55,6 & 6,21 & 8,82 & 1, & 45,8 & 5,51 \\
\hline 14 & 50,5 & 10,1 & 13,0 & 1,81 & 41,2 & 7,19 & 54,3 & 5,63 & 9,94 & 1,55 & 48,0 & 4,96 \\
\hline 15 & 51,0 & 5,78 & 13,9 & $1,7 \mathrm{~s}$ & 46,8 & 4,08 & 55,1 & 6,0 & 9,54 & 1,52 & 47,7 & 5,05 \\
\hline 16 & 51,8 & 19,7 & 3,07 & 1,9 & 34,7 & 17,4 & 54,3 & 5 & 10,5 & 1,53 & 47,7 & 4,52 \\
\hline 17 & 52,5 & 8,01 & 10,6 & 1,8 & 45,1 & 5,02 & 53,7 & 4 & 10,7 & 1,50 & 49,3 & 4,75 \\
\hline 18 & 51,8 & 14,7 & 7,85 & 1,9 & 37,2 & 15,4 & 55,8 & 5,13 & 9,86 & 1,58 & 48,5 & 5,13 \\
\hline 19 & 50,4 & 5,21 & 15,8 & 2,1 & 45 & 4,01 & 54,0 & 4, & 10,8 & 1, & 48 & 4,49 \\
\hline 20 & 51,8 & 4,01 & 15 & 2,4 & 46 & 3,00 & 55 & 5 & 9,2 & 1, & 48,7 & 5,25 \\
\hline 21 & 49,9 & 6,81 & 14 & 2,5 & 44 & 5,21 & 55,9 & 4,68 & 8,55 & 1, & 50,7 & 4,54 \\
\hline 22 & 54,9 & 3,89 & 10,5 & 2,23 & 51,0 & 2,94 & 54,9 & 4,63 & 10,9 & 1,52 & 49,3 & 4,20 \\
\hline 23 & 48,1 & 4,96 & 19,0 & 2,23 & 44,7 & 3,51 & 54,7 & 5,07 & 9,93 & 1,48 & 49,1 & 4,97 \\
\hline 24 & 47,8 & 7,28 & 15,5 & 2,35 & 44,9 & 4,89 & 54,3 & 5,51 & 8,76 & 1,60 & 48,9 & 5,36 \\
\hline 25 & 43,3 & 13,6 & 17,4 & 2,62 & 33,4 & 12,5 & 54,0 & 5,48 & 11,2 & 1,53 & 47,5 & 4,75 \\
\hline 26 & 43,2 & 12,4 & 17,9 & 1,91 & 35,5 & 10,8 & 54,5 & 5,14 & 10,5 & 1,56 & 48,4 & 4,45 \\
\hline 27 & 44,7 & 10,3 & 18,2 & 2,41 & 38,0 & 8,30 & 55,1 & 5,80 & 8,82 & 1,58 & 48,1 & 5,78 \\
\hline 28 & 55,1 & 7,67 & 5,75 & 2,51 & 48,6 & 7,05 & 54,5 & 5,53 & 11,0 & 1,67 & 47,6 & 5,33 \\
\hline 29 & 46,2 & 5,02 & 20,5 & 2,21 & 43,3 & 3,85 & 54,3 & 4,84 & 10,1 & 1,48 & 49,0 & 4,86 \\
\hline 30 & 53,3 & 4,86 & 11,9 & 2,14 & 49,0 & 3,81 & 54,8 & 5,15 & 10,5 & 1,49 & 48,9 & 4,73 \\
\hline
\end{tabular}

Obs: $\mathrm{Al}_{2} \mathrm{O}_{3}$ ap = alumina aproveitável, $\mathrm{SiO}_{2}$ re = sílica reativa 
As análises químicas foram efetuadas nas dependências laboratoriais da MRN por fluorescência de raios $X$, para determinações quantitativas de $\mathrm{Al}_{2} \mathrm{O}_{3}, \mathrm{SiO}_{2}$, $\mathrm{Fe}_{2} \mathrm{O}_{3}$ e $\mathrm{TiO}_{2}$ (em pérolas fundidas), além de dosagens específicas de alumina aproveitável e sílica reativa realizadas a partir de solubilizações parciais da amostra com $\mathrm{NaOH}$ e posterior análise do produto não solubilizado para obtenção de $\mathrm{SiO}_{2}$ livre (quartzo) e $\mathrm{Al}_{2} \mathrm{O}_{3}$ não reativa (gibbsita).

\subsection{Procedimento experimental}

A avaliação da difração de raios $X$ com método de Rietveld foi realizada através da comparação desses resultados com a composição mineralógica obtida por outros métodos quantificação, buscando-se qualidade e coerência de resultados quantitativos para sua aplicação como ferramenta para controle de operações de mina e processo.

Todas as análises e ensaios realizados foram efetuados no Laboratório de Caracterização Tecnológica do Departamento de Engenharia de Minas da Universidade de São Paulo - SP (LCT - EPUSP), com exceção à espectroscopia Mössbauer que foi realizada em laboratório do Departamento de Engenharia de Minas da Universidade Federal de Ouro Preto - MG.

O esquema do procedimento experimental adotado está exposto na Figura 27 e compreendeu as atividades descritas a seguir.

\subsubsection{Difratometria de raios $X$ para reconhecimento das amostras}

Análises por difração de raios $X$ para as 60 amostras de bauxita englobaram o seguinte conjunto de atividades de preparação de amostras:

- cominuição de todo o material em moinho de rolos, reduzindo a granulometria até $100 \%$ passante em $0,592 \mathrm{~mm}$ (28 malhas da série Tyler);

- homogeneização e tomada de alíquotas representativas através de quarteamento em amostrador centrífugo mecânico (equipamento FRITSCH Rotary Sample Divider - laborette 27 n. 27.141/629); 
- pulverização via úmida com etanol (proporção $50 \%$ em peso) de alíquotas com granulometria da ordem de 0,037 mm (400 malhas da série Tyler) utilizando-se moinho planetário (equipamento FRITSCH Pulverizette 05.202, $\mathrm{n}^{\circ}$. 3286), com panelas de aço de volume $300 \mathrm{~mL}$ e meio moedor de bolas de aço, 4 com diâmetro $20 \mathrm{~mm}$ e 3 com diâmetro 30 mm, em intensidade de rotação 7 e durante 10 min;

- montagem de pastilhas de DRX a partir de prensagem hidráulica (back loading) com carga de 1,5 t durante $5 \mathrm{~s}$ em suportes vazados, tipo anel.

A coleta dos difratogramas foi efetuada em equipamento X'Pert PRO, marca PANalytical, com configuração $\theta-\theta$ e detector sensível à posição X'Celerator.

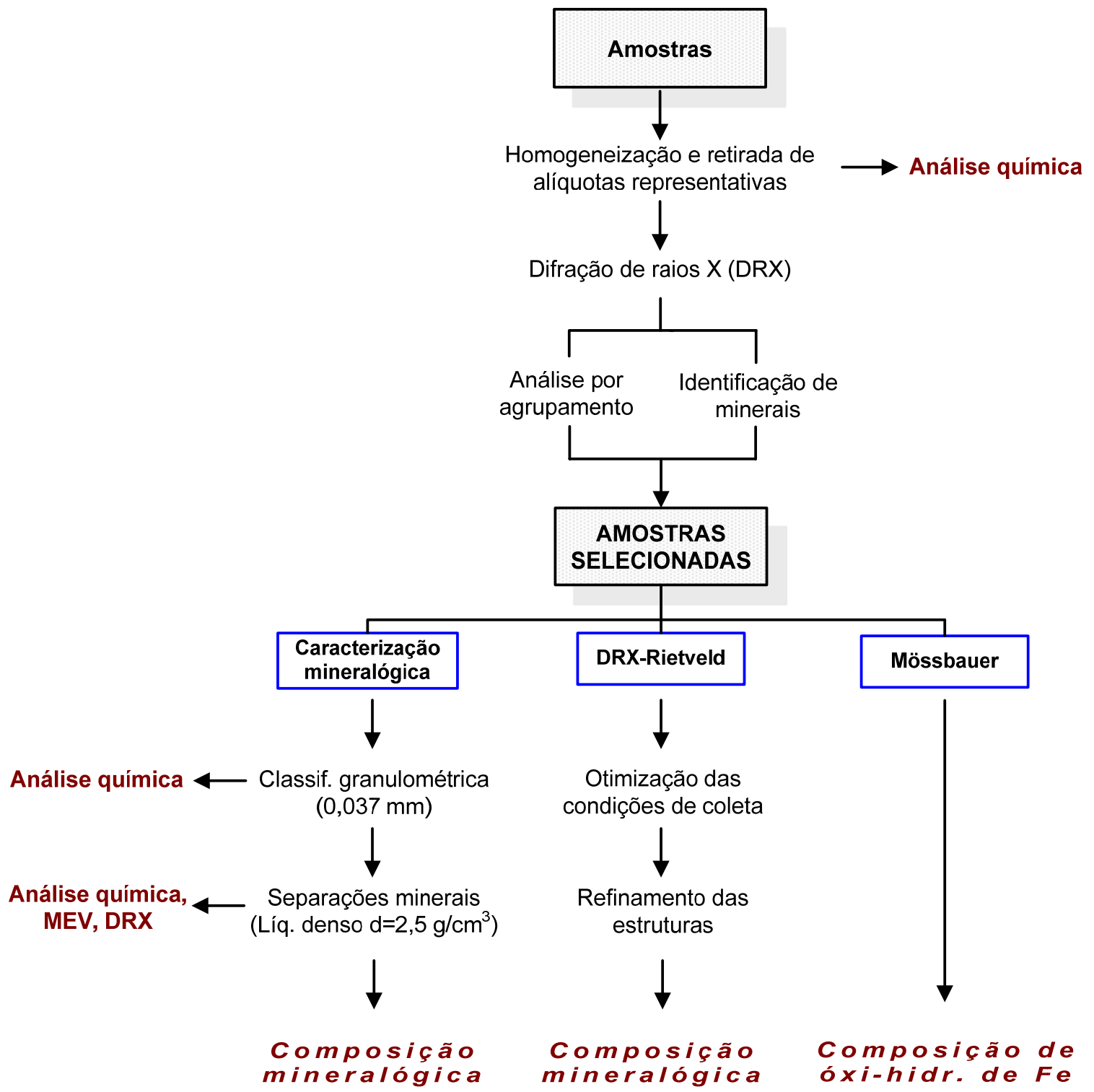

Figura 27 - Procedimento experimental adotado 


\subsubsection{Análise por agrupamento}

O recurso estatístico de análise por agrupamento foi utilizado para definição de tipos de minério dentre as bauxitas estudadas (60) considerando isoladamente os conjuntos da pesquisa e dos produtos de beneficiamento e, assim, serem selecionadas amostras representativas da variabilidade química e mineralógica dentre elas, para determinação da composição mineralógica.

O software aplicado foi o High Score Plus, marca PANalytical, que dispõe de facilidades para análises por agrupamento (cluster analysis) e refinamento por Rietveld. A definição dos agrupamentos de semelhança foi feita em função dos difratogramas coletados, de modo hierárquico e levando-se em consideração tanto o perfil quanto a posição e intensidade dos picos difratados, que refletem a variabilidade mineralógica das amostras. As análises químicas das amostras tal qual recebidas colaboraram com a verificação das diferenças entre os agrupamentos.

As condições empregadas na análise por agrupamento foram:

- dados de origem: perfil + picos

- figura de mérito (FOM): posição + intensidade

- limiar de comparação: $85 \%$

- medida de distância: Euclidiana

- método de ligação: média (Average Linkage)

- delimitação de grupos (cut-off): manual

Como resultado, as classes de amostras definidas puderam ser ilustradas através de dendogramas e por análise de componentes principais (PCA); esta última independe da análise por agrupamento e utiliza os dados da matriz de correlação, buscando varianças sistemáticas em grande número de dados, denominadas Eigenvalues, sendo que os três Engelvalues iniciais são apresentados em gráfico 3D (PCA1 a PCA3).

As classes definidas, além de possibilitarem a seleção de materiais representativos dentre o universo das amostras, permitiram o reconhecimento da assembléia mineralógica constituinte do mesmo. Foram, assim, selecionadas 10 amostras compreendendo amostras $\mathrm{P}$ (pesquisa) e $\mathrm{U}$ (processo), para as quais foram desenvolvidas estratégias de refinamento por Rietveld e foram realizadas 
determinações mineralógicas por procedimentos de caracterização mineralógica e espectroscopia de Mössbauer para aferição dos resultados obtidos por DRXRieveld.

\subsubsection{Caracterização mineralógica}

Estudos de caracterização mineralógica das amostras foram realizados a partir da conjugação de resultados de classificação granulométrica, separações minerais, cálculos mineralógicos apoiados em análises químicas e difratometria de raios $X$, além de observações sistemáticas em microscópio eletrônico de varredura.

A seguinte seqüência de atividades foi aplicada as 10 amostras selecionadas:

- classificação granulométrica de alíquota representativa ( 400 g) por peneiramento a úmido em peneira com abertura de 0,037 mm (400 malhas Tyler) e análises químicas das frações geradas;

- separação em líquido denso (bromofórmio + álcool; densidade=2,5 $\mathrm{g} / \mathrm{cm}^{3}$ ) na fração retida em $0,037 \mathrm{~mm}$, seguida de análises químicas e difratometria de raios $\mathrm{X}$ dos produtos gerados;

- estimativa da composição mineralógica através de cálculos estequiométricos, considerando-se a fórmula teórica dos minerais constituintes.

A escolha pela densidade (d) na separação mineral foi feita com base em valores de massa específica das fases constituintes das amostras e procurando-se concentrar espécies minerais em determinados produtos, com vista a simplificar a estimativa mineral apoiada em análises químicas. Considerando-se partículas livres, a gibbsita (maior constituinte das amostras), pode ser separada dos demais minerais, pois sua densidade é inferior ao líquido $\left(\mathrm{d}=2,3-2,4 \mathrm{~g} / \mathrm{cm}^{3}\right)$, enquanto que a caulinita $\left(d=2,6-2,63 \mathrm{~g} / \mathrm{cm}^{3}\right)$ tende a afundar, assim como o quartzo $\left(\mathrm{d}=2,65 \mathrm{~g} / \mathrm{cm}^{3}\right)$ e os demais constituintes (óxi-hidróxidos de ferro, óxidos de titânio e outros), todos com densidade superior a $3 \mathrm{~g} / \mathrm{cm}^{3}$.

As análises químicas realizadas no decorrer dos ensaios, com determinações quantitativas de $\mathrm{Al}_{2} \mathrm{O}_{3}, \mathrm{SiO}_{2}, \mathrm{Fe}_{2} \mathrm{O}_{3}$, e $\mathrm{TiO}_{2}$ (em pérolas fundidas), foram realizadas por fluorescência de raios $\mathrm{X}$ em espectrômetro Axios Advanced, marca PANalytical; 
foi efetuada também a determinação da perda ao fogo (PF; temperatura de $100{ }^{\circ} \mathrm{C}$ por uma hora), sendo que análises específicas de alumina aproveitável e sílica reativa foram realizadas nos laboratórios da MRN.

A identificação das fases minerais componentes das amostras tal qual e de produtos obtidos das separações minerais foi realizada a partir do software High Score Plus (versão 2.2d, 2008) da PANalytical, por comparação dos difratogramas com banco de dados PDF2 do ICDD - International Centre for Diffraction Data (2003) e PAN-ICSD - PANalytical Inorganic Crystal Structure Database (2007).

Observações ao microscópio eletrônico de varredura (MEV-EDS) foram realizadas em produtos flutuados da separação em líquido denso, preparados em seções polidas com recobrimento de carbono. O intuito foi avaliar qualitativa e semiquantitativamente os elementos químicos presentes nos diversos minerais constituintes, atentando-se para a forma de ocorrência da gibbsita e sua associação com a ganga. A análise foi efetuada em configuração de elétrons retroespalhados utilizando-se:

- microscópio eletrônico de varredura marca LEO, modelo Stereoscan 440 com espectrômetro de dispersão de energia (EDS) de SDD (silicon drift detector) modelo INCA X-act e software para microanálise INCA, marca Oxford.

- microscópio eletrônico de varredura marca FEl, modelo Quanta 600 FEG, com espectrômetro de dispersão de energia (EDS) de SDD modelo XFlash 4030, com software para microanálise Esprit, marca Bruker.

\subsubsection{Difração de raios $X$ com o método de Rietveld}

A quantificação de fases por DRX com o método de Rietveld englobou as seguintes etapas de atividades:

\section{$\checkmark \quad$ Otimização da montagem de amostras para DRX-Rietveld}

Visando à minimização da orientação preferencial intensificada no momento da montagem de amostras para a DRX, foram realizados testes para definição da melhor condição hidráulica de prensagem (tonelagem / tempo; back loading) e 
avaliadas as variações de altura dos picos das espécies minerais de acordo com a condição de prensagem aplicada.

Os testes foram realizados em três amostras, selecionadas de forma a priorizar-se a variabilidade de proporções minerais contidas, conforme a Figura 28. As amostras escolhidas foram as seguintes:

- A - amostra com elevado teor gibbsita;

- B - amostra contendo elevado teor de caulinita;

- C - amostra contendo teores intermediários de gibbsita e caulinita.

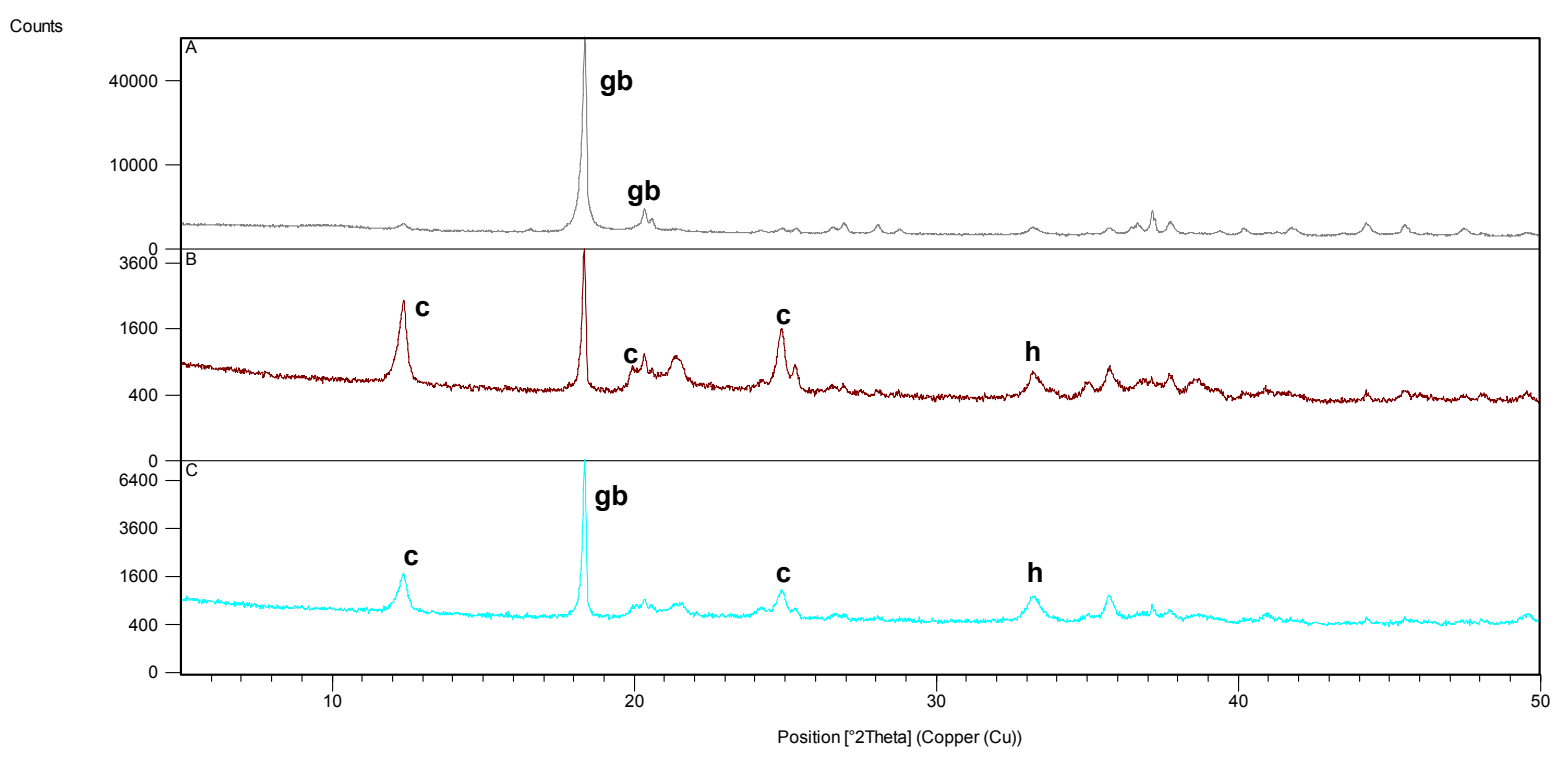

Figura 28 - Difratogramas comparativos das amostras A, B e C utilizadas nos testes de definição de condições de prensagem (gb=gibbsita; $c=$ caulinita; $h=$ hematita)

Considerando-se a força aplicada na prensagem hidráulica, foi definida como ideal a tonelagem de 1,5 , já que as outras cargas avaliadas (3, 5, 10 ton) se mostraram inviáveis operacionalmente, acarretando, na grande maioria dos casos, o deslocamento da amostra para cima do nível de altura do suporte, quando não ocorrendo sua total expulsão. A Figura 29 ilustra a comparação dos difratogramas especificamente da amostra A, na qual foi possível a prensagem para as diferentes cargas; observa-se a intensificação da orientação preferencial do pico (002) da gibbsita, conforme aumento da força empregada.

Considerando-se a duração da prensagem, foi definido como ideal o tempo de 30s, já que durações inferiores a 20s não apresentam comportamento adequado aos 
3 tipos de amostras, conforme exemplificado na Figura 30 para as intensidades do pico (002) da gibbsita e (001) da caulinita.

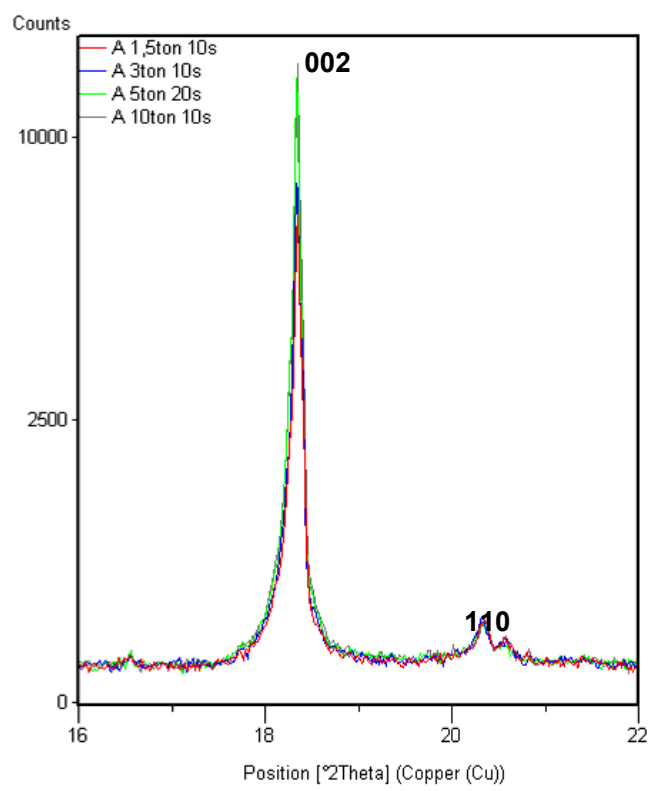

Figura 29 - Difratogramas comparativos para diferentes condições de prensagem hidráulica $(1,5,3,10$ toneladas). Detalhe para picos (002) e (110) da gibbsita - amostra A

(I)
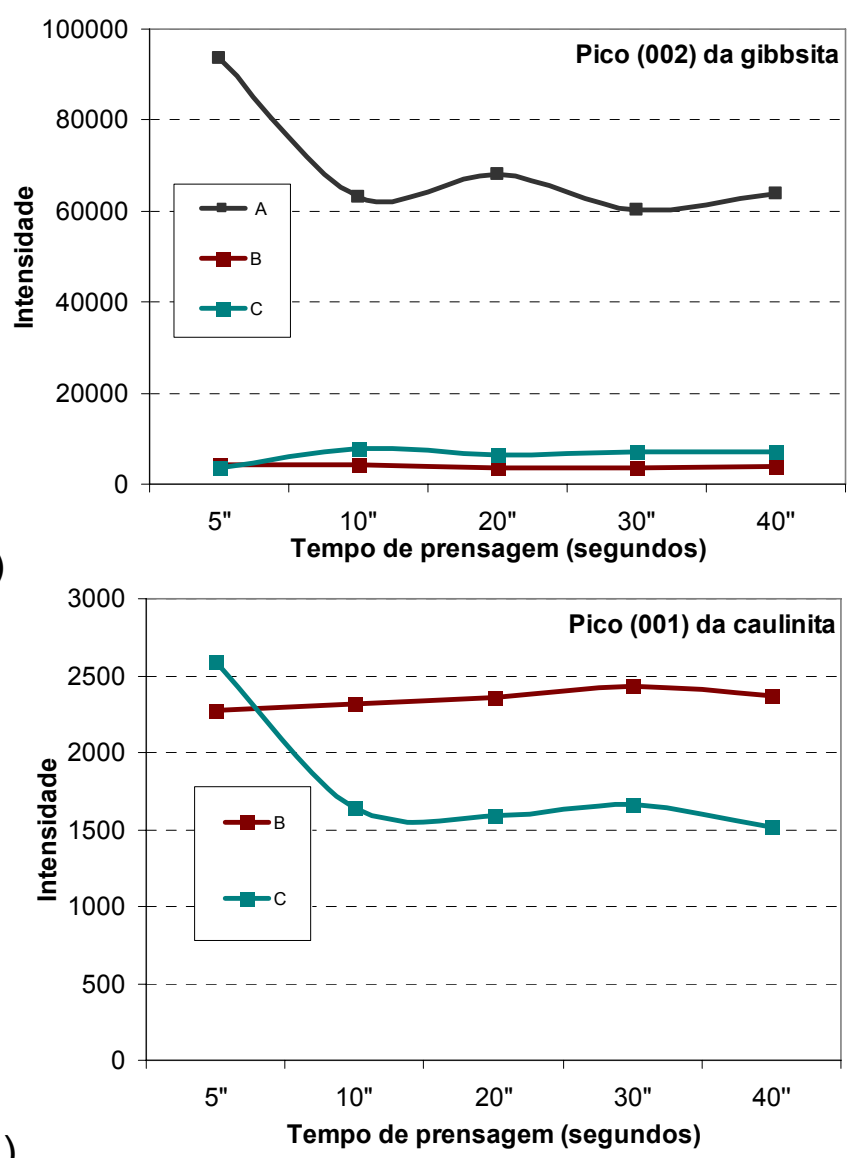

Figura 30 - Variações na intensidade dos picos (002) da gibbsita (I) e (001) da caulinita (II) para diferentes tempos de prensagem hidráulica (amostra A contém caulinita insuficiente para a medição de seus picos) 


\section{$\checkmark \quad$ Condições de coleta dos difratogramas}

A Tabela 4 apresenta as condições instrumentais definidas como ideais na coleta dos difratogramas, para os estudos propostos e considerando as características do material analisado.

Tabela 4 - Condições instrumentais aplicadas na coleta dos difratogramas

\begin{tabular}{|c|c|c|}
\hline Aplicação & Identificação mineralógica & Quantificação Rietveld \\
\hline Radiação & $\mathrm{Cu} \mathrm{K}_{\alpha}(\lambda=1,54186 \AA)$ & $\mathrm{Cu} \mathrm{K}_{\alpha}(\lambda=1,54186 \AA)$ \\
\hline Energia no tubo (voltagem $x$ corrente) & $45 \mathrm{kV} \times 40 \mathrm{~mA}$ & $45 \mathrm{kV} \times 40 \mathrm{~mA}$ \\
\hline Faixa angular $\left({ }^{\circ} 2 \theta\right)$ & 2,5 a $70^{\circ}$ & 2,5 a $70^{\circ}$ \\
\hline Passo angular $\left({ }^{\circ} 2 \theta\right)$ & $0,02^{\circ}$ & $0,02^{\circ}$ \\
\hline Tempo de coleta por passo & $5 s$ & $5 s$ \\
\hline Tempo total de coleta & $2 \min 40 s$ & $2 \min 40 s$ \\
\hline Rotação (spinner) & 0,5 revolução/s & 2 revolução / s \\
\hline Fenda Soller & $0,04 \mathrm{rad}$ & $0,04 \mathrm{rad}$ \\
\hline Fenda de divergência & Fixa de $1 / 8^{\circ}$ & Fixa de $1 / 2^{\circ}$ \\
\hline Fenda de espalhamento & Fixa de $1 / 4^{\circ}$ & Fixa de $1^{\circ}$ \\
\hline Máscara & $10 \mathrm{~mm}$ & $15 \mathrm{~mm}$ \\
\hline Filtro $\mathrm{K}_{\beta}$ & $\mathrm{Ni}$ & $\mathrm{Ni}$ \\
\hline
\end{tabular}

Com o intuito de aprimorar a estatística das partículas e a resolução dos difratogramas para realização da análise quantitativa pelo método de Rietveld, algumas adaptações na configuração da coleta (basicamente rotação de amostra e abertura de fendas) foram efetuadas, com relação àquela inicialmente utilizada na análise por agrupamento e reconhecimento inicial da assembléia mineralógica constituinte das amostras (identificação mineralógica).

\section{$\checkmark \quad$ Definição de estruturas cristalinas}

A escolha de estruturas condizentes com as fases identificadas foi feita a partir do programa High Score Plus e dos bancos de dados anteriormente citados. As estruturas selecionadas para os refinamentos por Rietveld (PAN-ICSD) foram:

- gibbsita - cód. ICSD 6162. Zeitschrift fuer Kristallographie, Kristallgeometrie, Kristallphysik, Kristallchemie. V139, 1974. Autores: Wedde, M.; Saalfeld, $\mathrm{H}$.

- caulinita - cód. ICSD 68698. Jornal Crystal Research and Technology. V25, 1990. Autores: Abdel Rahman, A.M.; Heiba, Z.K.; El Sayed, K. 
- hematita - cód. ICSD 24791. Cód. JPCSAW, V10, 1959. Autores: Shirane, G.; Pickart, S.J.; Nathans, R.; Ishikawa, Y.

- anatásio - cód. ICSD 82084. Journal of Solid State Chemistry. V122, 1996. Autores: Novaro, O.; Morales, A.; Bokhimi, X.; Gomez, R.; Lopez, T.; Sanchez, E.

- goethita - cód. ICSD 71808. Physics and Chemistry of Minerals. V19, 1992. Autores: Manceau, A.; Berar, J.F.; Hazemann, J.L. e/ou cód. ICSD 28247. Physica StatusSolidi. V26, 1968. Autores: Wolski, W.; Wanic, A.; Todorovic, J.; Rzany, H.; Krasnicki, S.; Dimitrijevic, Z.; Burewicz, A.; Szytula, A.

- quartzo - cód. ICSD 89278. European Journal of Mineralogy. V2, 1990. Autor: Kihara, K.

- dickita - cód. ICSD 30996. Jahrbuch fuer Mineralogie. 1986. Autores: Drits, V.A.; Joswig, W.

- dickita 2M - cód. ICSD 16653. Acta Crystallographica. V10, 1957. Autores: Brindley, G.W.; Newnham, R.E.

- groutita - cód. ICSD 43000. Golden Book of Phase Transitions. V1, 2002. Autores: Ingram, L.; Dent Glasser, L.S.

- zircão - cód. ICSD 69645. Zeitschrift fuer Anorganische und Allgemeine Chemie. V583, 1990. Autores: Jansen, M.; Siggel, A.

- haloisita - cód. ICSD 26716. Zeitschrift fuer Kristallographie, Kristallgeometrie, Kristallphysik, Kristallchemie. V90, 1935. Autor: Mehmel, M.

\section{$\checkmark \quad$ Estratégias de refinamento}

Foram definidas 5 estratégias de refinamento, adaptadas para os grupos de amostras similares, para que todas as 10 amostras fossem refinadas satisfatoriamente, considerando suas características mineralógicas.

Este seqüenciamento de parâmetros refinados se mostrou fundamental, tornando as quantificações muito mais precisas quando se considera a uniformidade da metodologia aplicada a um determinado tipo de material. 
Os principais parâmetros aplicados aos refinamentos foram fator escala, cela unitária e fator $W$ de perfil de pico das fases constituintes, além da orientação preferencial para a gibbsita e, em alguns casos, para a caulinita. Destaca-se que os menores constituintes das amostras são pouco trabalhados nas estratégias de refinamento.

A aferição dos resultados foi feita através da constante avaliação do valor GOF, $R_{w p}$ e da qualidade do gráfico diferencial, gerados durantes os cálculos iterativos.

\subsubsection{Análises por espectroscopia Mössbauer}

Análises por espectroscopia Mössbauer de transmissão do ${ }^{57} \mathrm{Fe}$ foram realizadas à temperatura ambiente em espectrômetro operando no modo de aceleração constante, com 512 ou 1024 canais. A calibração da velocidade foi realizada com um absorvedor de ferro metálico e os desvios isométricos são relativos ao a-Fe.

Os espectros foram ajustados utilizando-se o programa MOSF e o programa DIST3E, o qual é baseado em um modelo independente de distribuição dos campos hiperfinos e/ou desdobramentos quadrupolares. Os resultados numéricos dos ajustes são reportados como parâmetros hiperfinos, representados pelo desdobramento quadrupolar $(\varepsilon ; \mathrm{mm} / \mathrm{s})$, campo magnético hiperfino $\left(\mathrm{H}_{\mathrm{hf}}\right)$ e área relativa (\%).

As proporções de cada uma fases minerais portadoras de ferro, identificadas através de espectroscopia Mössbauer, foram calculadas a partir da conjugação dos valores de áreas relativas obtidas (\%) com as densidades e composições estequiométricas teóricas das fases portadoras, além dos teores de $\mathrm{Fe}_{2} \mathrm{O}_{3}$ dosados pela MRN. 


\section{RESULTADOS}

\subsection{Mineralogia das bauxitas}

A identificação das espécies minerais foi essencialmente realizada através de análises por difratometria de raios $\mathrm{X}$. Complementarmente foi feita uma investigação mais detalhada da gibbsita e de suas formas de associação, por meio de microscopia eletrônica de varredura com apoio de microanálise por EDS.

\subsubsection{Identificação das espécies minerais}

Os difratogramas de raios $\mathrm{X}$ obtidos para as 60 amostras apresentaram significativa semelhança em termos de posição e intensidades relativas entre picos, o que confere similaridade à assembléia mineralógica das mesmas. Os minerais identificados foram: gibbsita, argilominerais (essencialmente minerais do grupo da caulinita) e hematita, além de menores quantidades de anatásio e, mais raramente, goethita e quartzo; zircão e groutita também podem estar presentes, geralmente como minerais traços.

A Figura 31 traz a sobreposição dos 60 difratogramas gerados e a identificação específica dos picos relacionados às principais fases minerais constituintes.

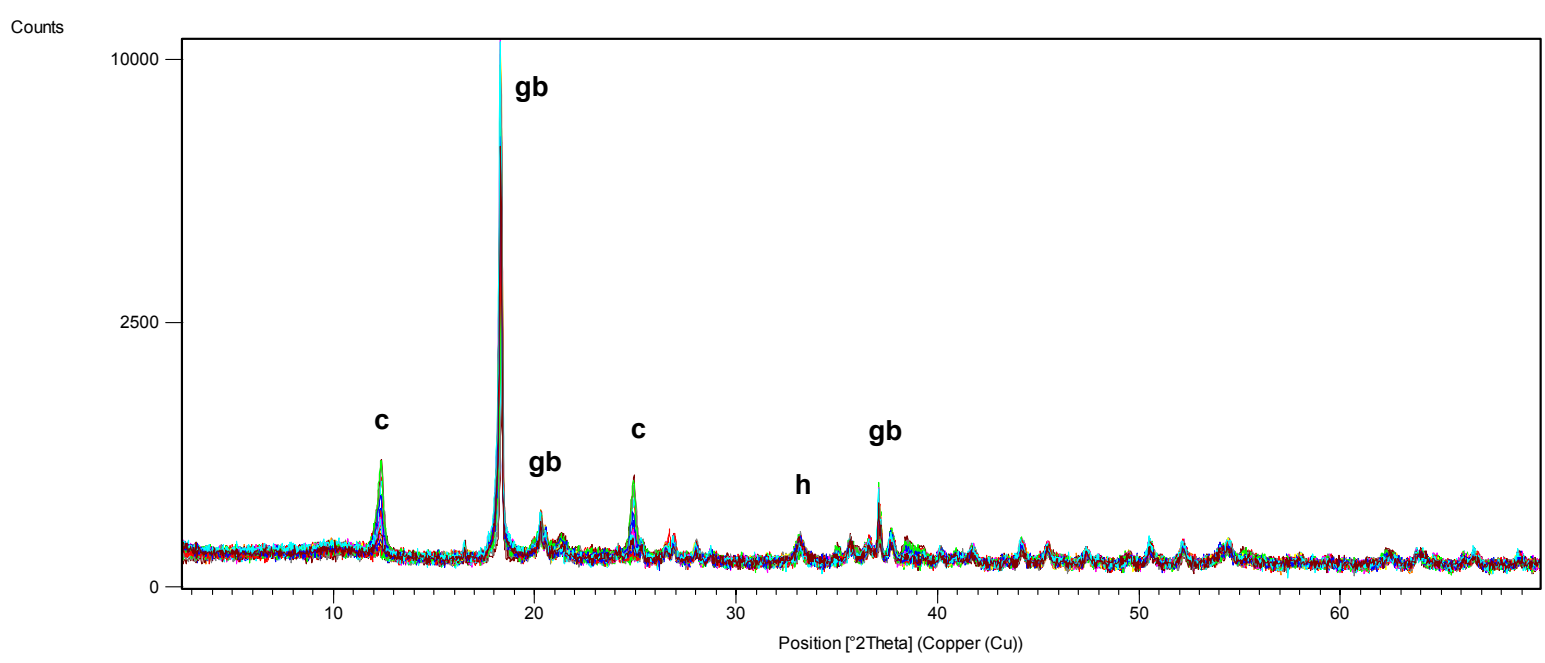

Figura 31 - Sobreposições dos difratogramas das 60 amostras em estudo. Semelhança mineralógica observada pela similaridade da posição e intensidades relativas dos picos das amostras (gb=gibbsita; $c=$ caulinita; $h=$ hematita) 


\subsubsection{Formas de ocorrência da gibbsita}

As principais características das associações da gibbsita com os demais minerais constituintes são evidenciadas em fotomicrografias obtidas por microscopia eletrônica de varredura (MEV/EDS), para os produtos das separações minerais que concentram valores superiores a $75 \%$ da gibbsita total das amostras (fração retida em $0,037 \mathrm{~mm})$.

A gibbsita mostra-se na forma de cristais bem desenvolvidos de dimensões variadas entre 10 a 500 micrômetros e também em massas de cristalitos submicrométricos; ambas as formas ocorrem normalmente associadas, mostrando a predominância de partículas mistas no material cominuído abaixo de 0,592 $\mathrm{mm}$. A Fotomicrografia 1 apresenta as massas muito finas de composição gibbsíticacaulinítica que aparecem intimamente associadas ou simplesmente na borda de cristais de gibbsita, a qual permanece como núcleos preservados.

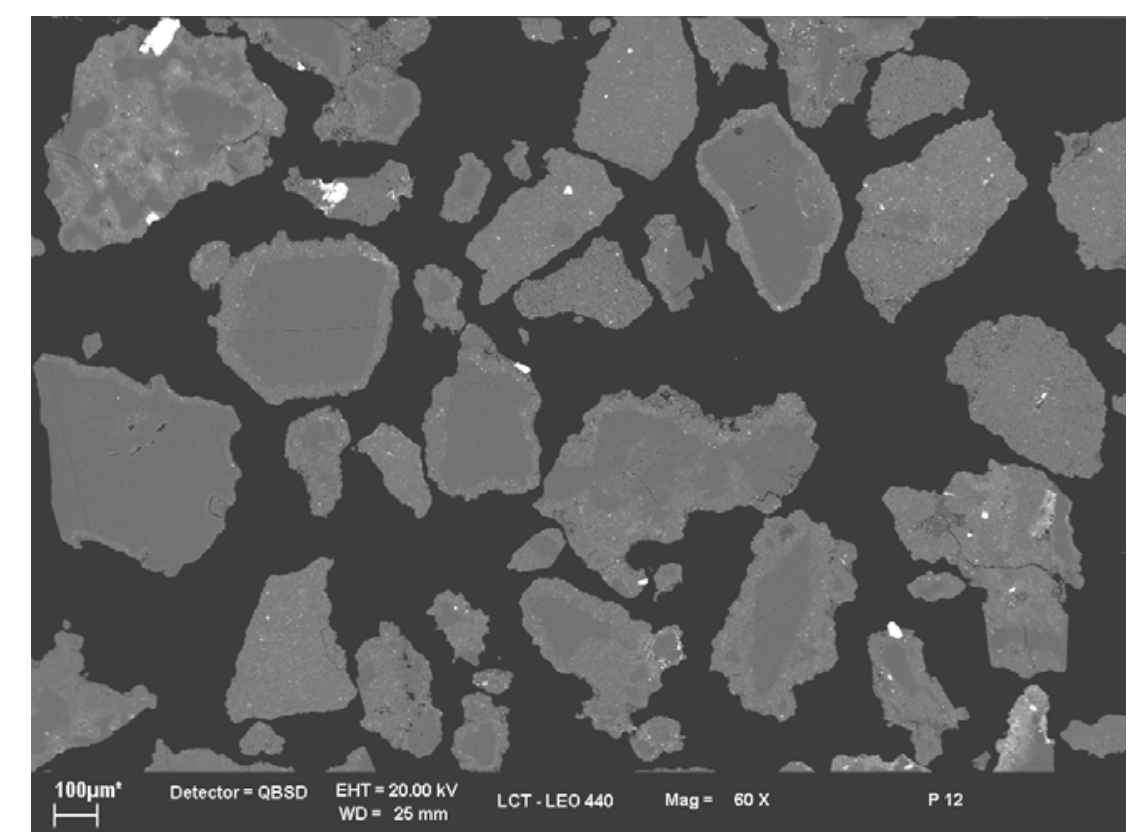

Fotomicrografia 1 - Imagem de MEV com detector de elétrons retroespalhados. Gibbsita (coloração cinza escuro), preferencialmente mista com massas de composição gibbsitaargilominerais (cinza mais claro) e minerais de ferro em branco

Partículas de gibbsita livres são também observadas e permitem, muitas vezes, a visualização do hábito lamelar a tabular desses cristais. $O$ mineral apresenta superfície límpida e homogênea, sendo que espectros de EDS não identificam outros elementos em sua estrutura cristalina (Fotomicrografia 2 e Fotomicrografia 3). 


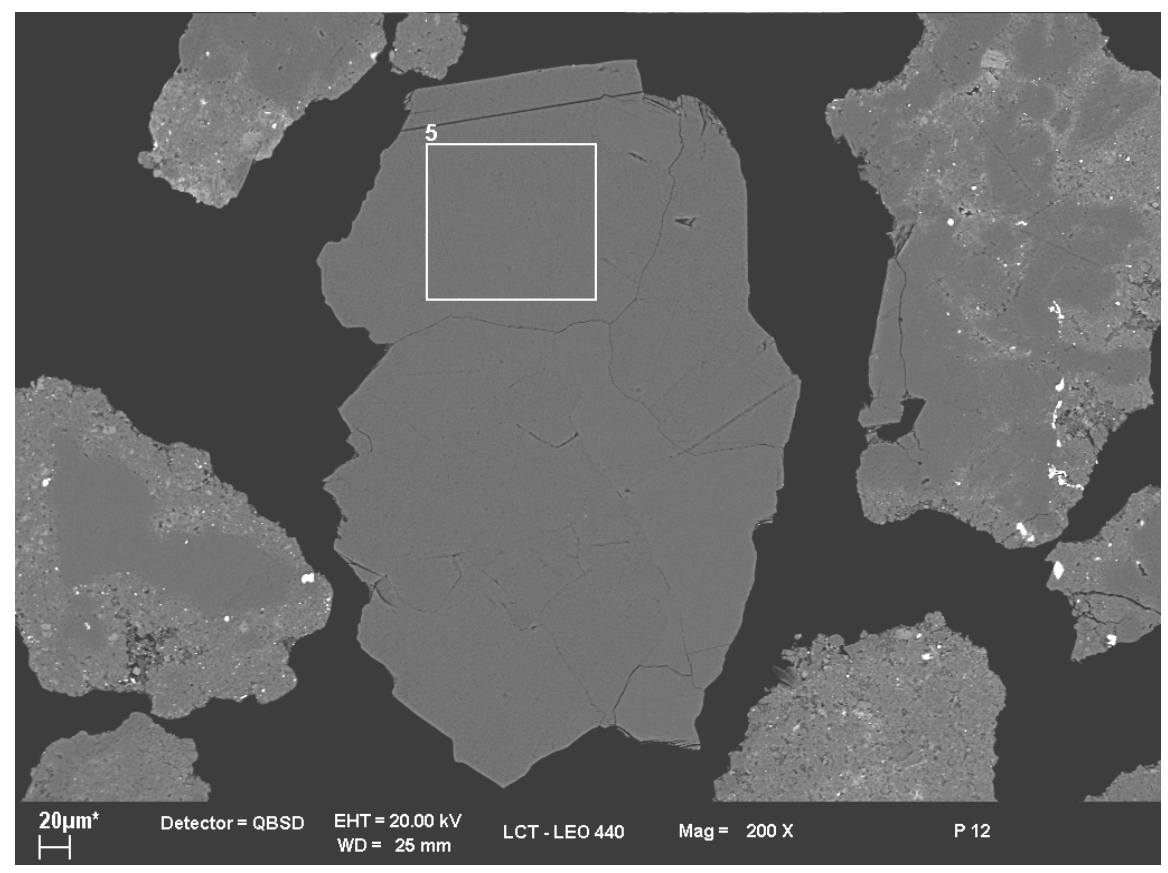

Fotomicrografia 2 - Imagem de MEV com detector de elétrons retroespalhados. Cristal límpido de gibbsita, sem outros elementos em sua estrutura

Microanálise por EDS (\% em peso)

\begin{tabular}{|c|c|c|c|c|}
\hline Espectro & $\mathrm{Al}_{2} \mathrm{O}_{3}$ & $\mathrm{SiO}_{2}$ & $\mathrm{Fe}_{2} \mathrm{O}_{3}$ & $\mathrm{TiO}_{2}$ \\
\hline 1 & 60,4 & & & \\
\hline
\end{tabular}
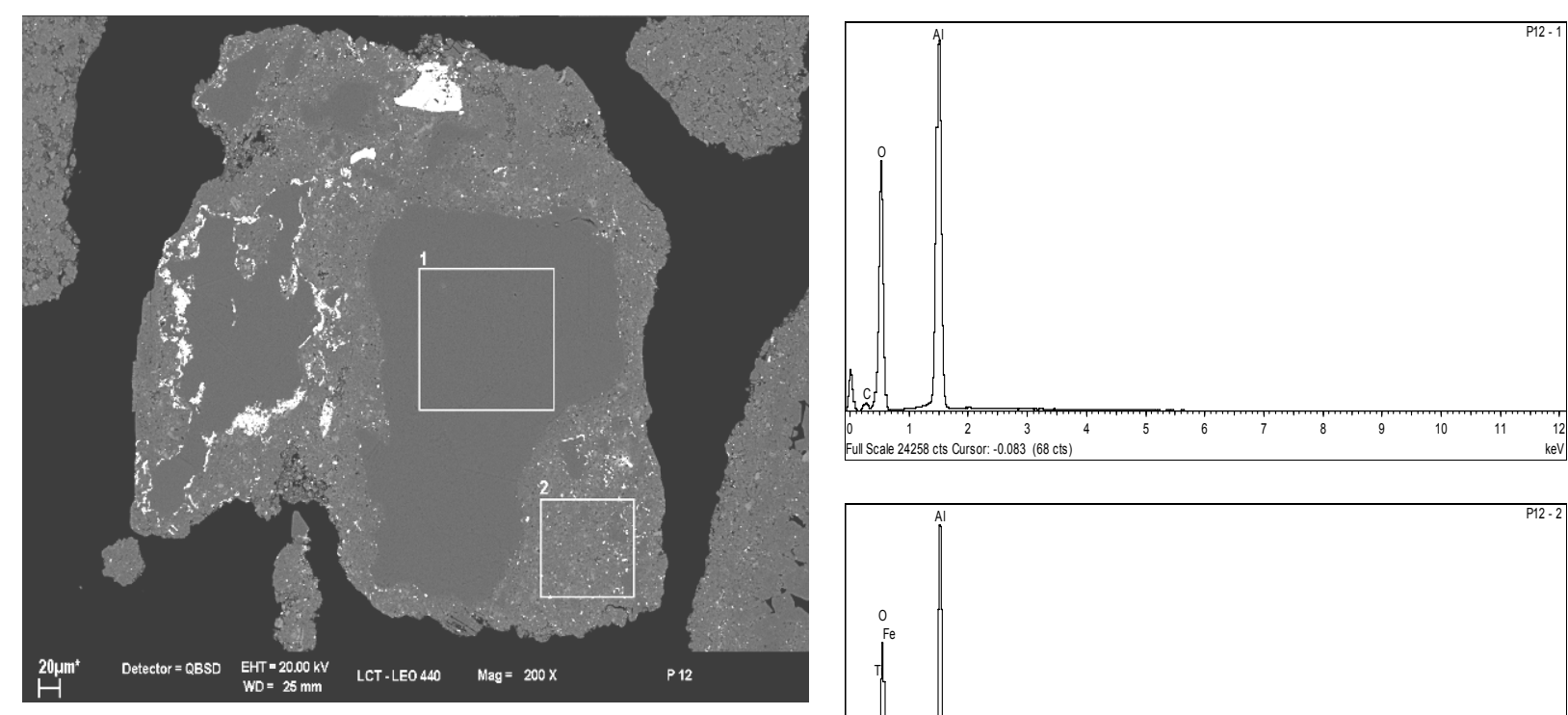

Microanálise por EDS (\% em peso)

\begin{tabular}{|c|c|c|c|c|}
\hline Espectro & $\mathrm{Al}_{2} \mathrm{O}_{3}$ & $\mathrm{SiO}_{2}$ & $\mathrm{Fe}_{2} \mathrm{O}_{3}$ & $\mathrm{TiO}_{2}$ \\
\hline 1 & 59,9 & & & \\
\hline 2 & 52,1 & 16,2 & 0,97 & 1,15 \\
\hline
\end{tabular}

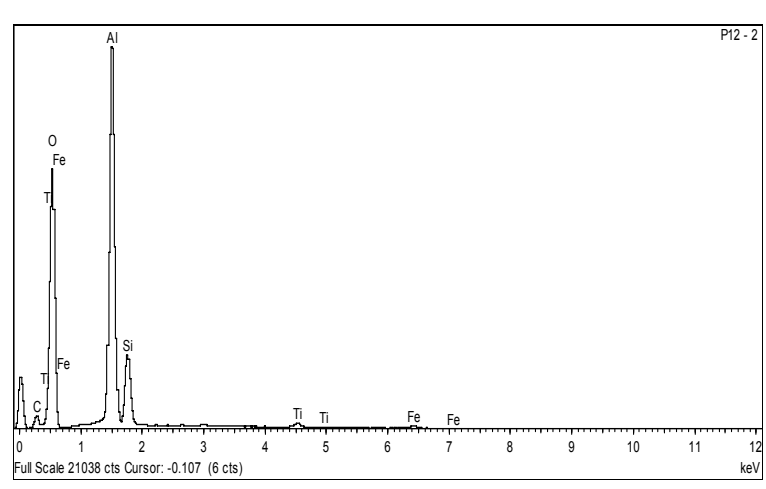

Fotomicrografia 3 - Imagem de MEV com detector de elétrons retroespalhados. Associação de gibbsita, massa gibbsita-argilominerais e dispersos cristalitos de óxi-hidróxidos de $\mathrm{Fe}$ e $\mathrm{Ti}$ (tons claros, brancos) 
As chamadas massas de composição gibbsítica-caulinítica referem-se a intercrescimentos de gibbsita com argilominerais, em dimensões submicrométricas (<100 nm), na maioria das vezes indistinguíveis sob microscopia eletrônica. Dentro dessa matriz são ainda observados cristais bem definidos de caulinita que chegam a $10 \mu \mathrm{m}$ e aparecem dispostos aleatoriamente (Fotomicrografia 3 e Fotomicrografia 4), além de cristalitos de óxidos e hidróxidos de Fe e Ti, também com granulação submicrométrica $(<100 \mathrm{~nm})$.
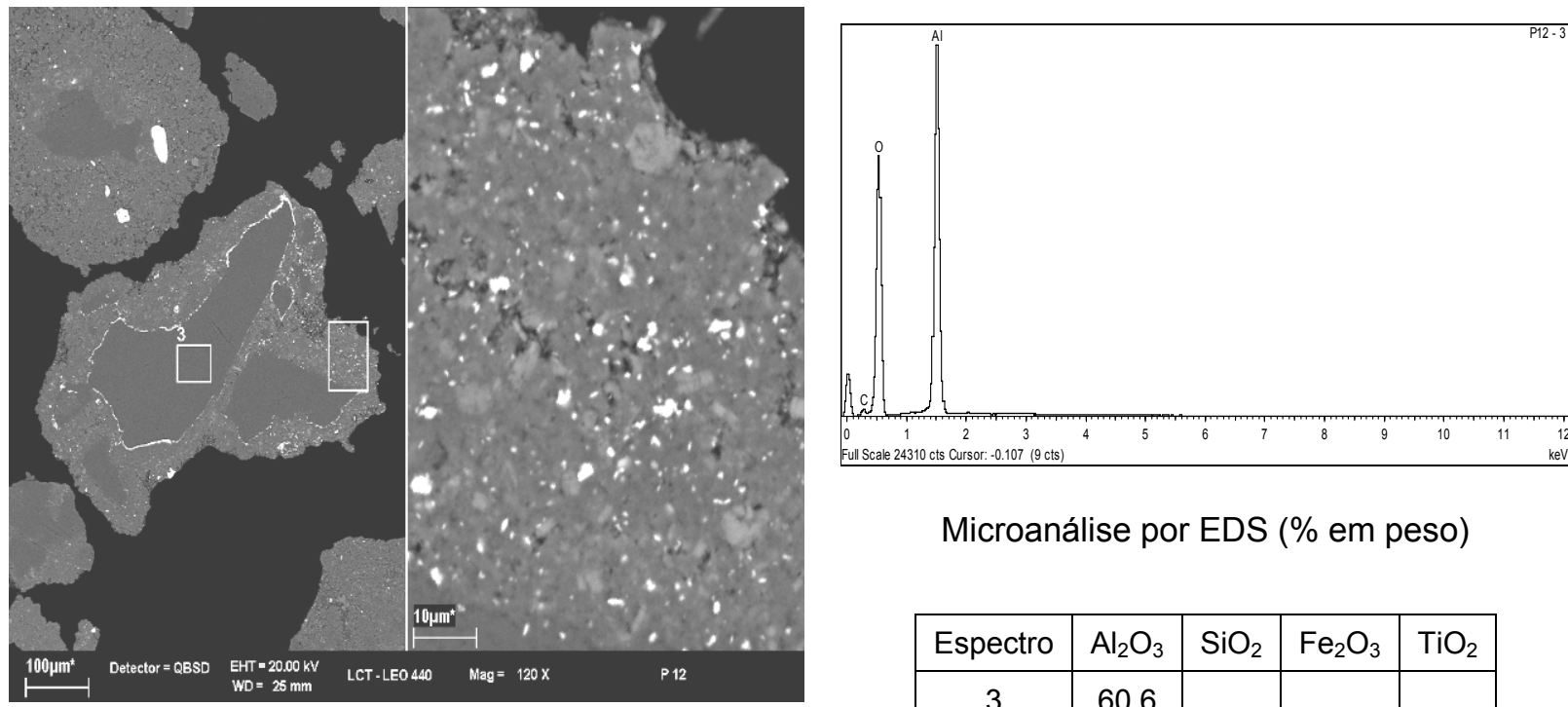

Microanálise por EDS (\% em peso)

\begin{tabular}{|c|c|c|c|c|}
\hline Espectro & $\mathrm{Al}_{2} \mathrm{O}_{3}$ & $\mathrm{SiO}_{2}$ & $\mathrm{Fe}_{2} \mathrm{O}_{3}$ & $\mathrm{TiO}_{2}$ \\
\hline 3 & 60,6 & & & \\
\hline
\end{tabular}

Fotomicrografia 4 - Imagem de MEV com detector de elétrons retroespalhados. Associação de cristal de gibbsita e a massa com intercrescimento de gibbsita e argilominerais; no detalhe à direita observam-se diminutos cristais de óxi-hidróxidos de Fe (cor branca)

Por vezes, óxidos e hidróxidos de ferro concentram-se como agregados porosos de cristalinidade aparentemente baixa, tanto nas massas de gibbsitacaulinita como nos cristais de gibbsita, como áreas enriquecidas em $\mathrm{Fe}$ (Fotomicrografia 5).

Raramente são ainda observados grãos de anatásio/rutilo, zircão e quartzo, com formas subarredondadas.

A composição química das massas de gibbsita-caulinita, obtida em mapeamentos de raios $X$ para os elementos maiores constituintes: $\mathrm{Al}, \mathrm{Si}, \mathrm{Fe} \mathrm{e} \mathrm{Ti}$, associada a aspectos morfológicos dos constituintes minerais identificáveis na massa, possibilitou a definição de sua composição mineralógica e ilustra as características anteriormente citadas (Fotomicrografia 6). 


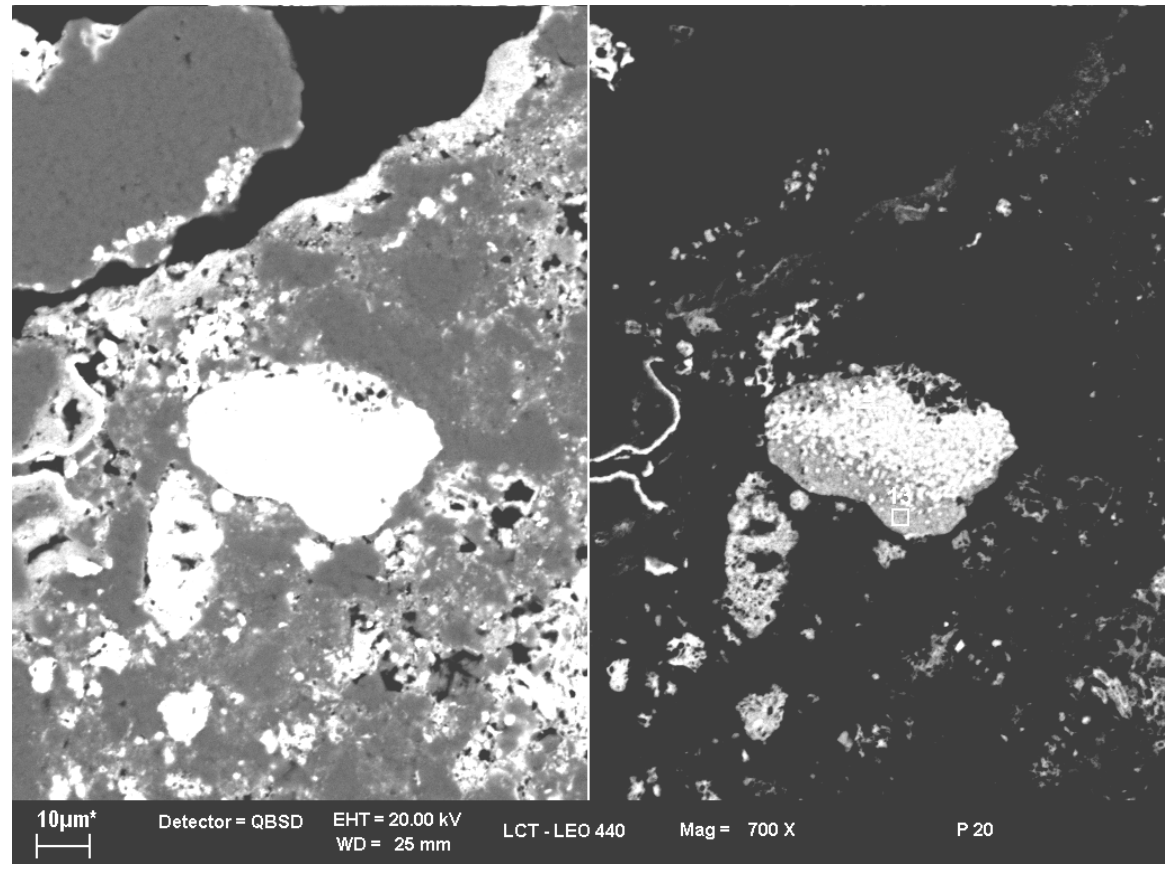

Fotomicrografia 5 - Imagem de MEV com detector de elétrons retroespalhados. Detalhe para óxi-hidróxidos de Fe, com aspecto poroso e heterogêneo

Microanálise por EDS (\% em peso)

\begin{tabular}{|c|c|c|c|c|}
\hline Espectro & $\mathrm{Al}_{2} \mathrm{O}_{3}$ & $\mathrm{SiO}_{2}$ & $\mathrm{Fe}_{2} \mathrm{O}_{3}$ & $\mathrm{TiO}_{2}$ \\
\hline 12 & 1,50 & 1,16 & 90,1 & 0,85 \\
\hline 13 & 2,83 & 0,86 & 77,7 & 1,07 \\
\hline
\end{tabular}
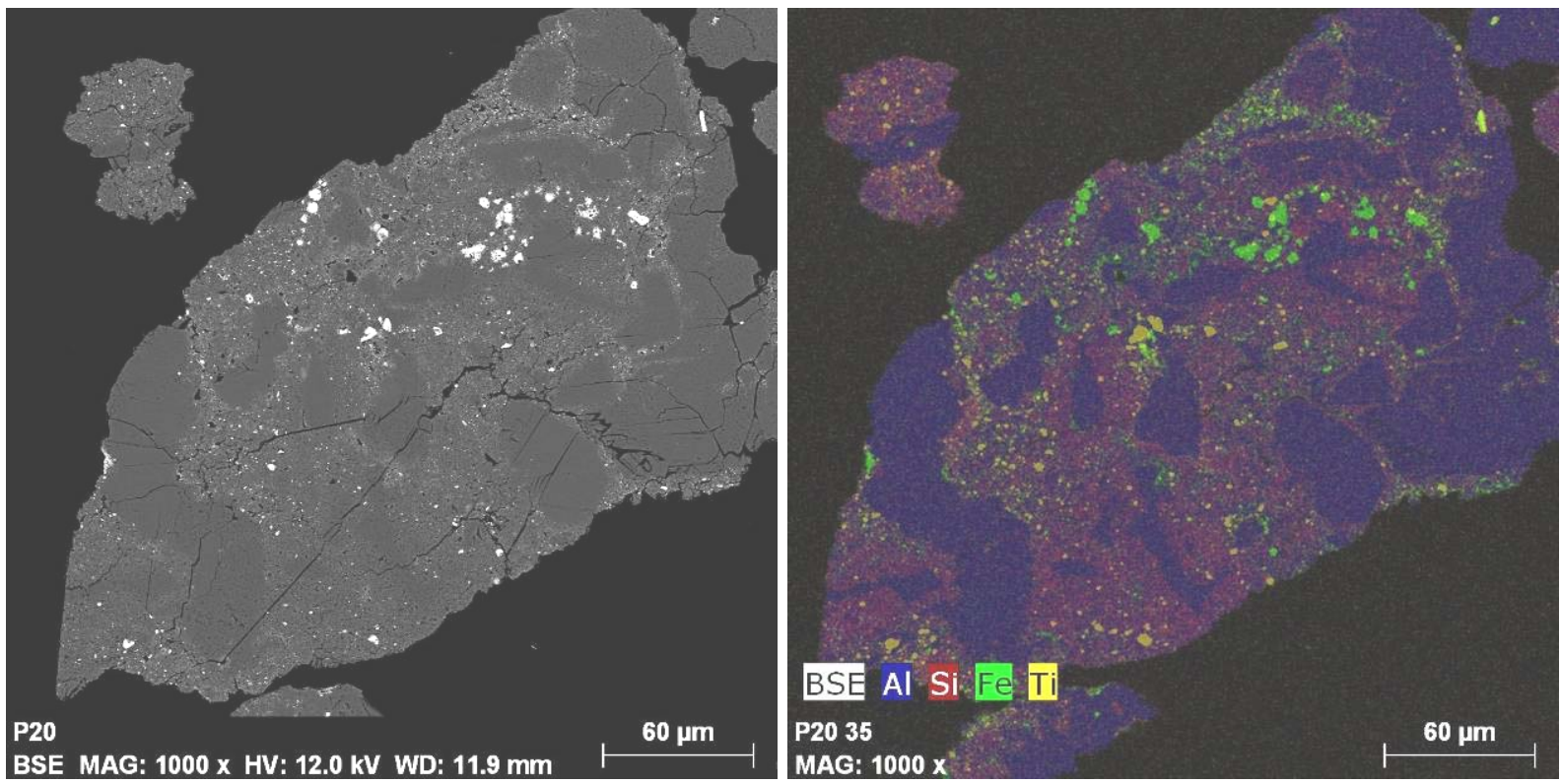

Fotomicrografia 6 - Mapeamento de raios $X$ na imagem à direita, ilustrando a distribuição dos elementos químicos na massa de gibbsita-caulinita. Gibbsita em azul, massa gibbsíticacaulinítica em tons azul-avermelhados, óxi-hidróxidos de Fe em verde e óxidos de Ti em amarelo. 


\subsection{Análise por agrupamento}

Os agrupamentos das amostras em função de seus padrões difratométricos foram tratados isoladamente para o conjunto de amostra da pesquisa mineral $(P)$ e os produtos de processo de beneficiamento $(U)$.

O dendograma obtido para as amostras $\mathrm{P}$ é apresentado na Figura $32 \mathrm{e}$ ilustra o agrupamento dessas amostras em quatro conjuntos de semelhança.

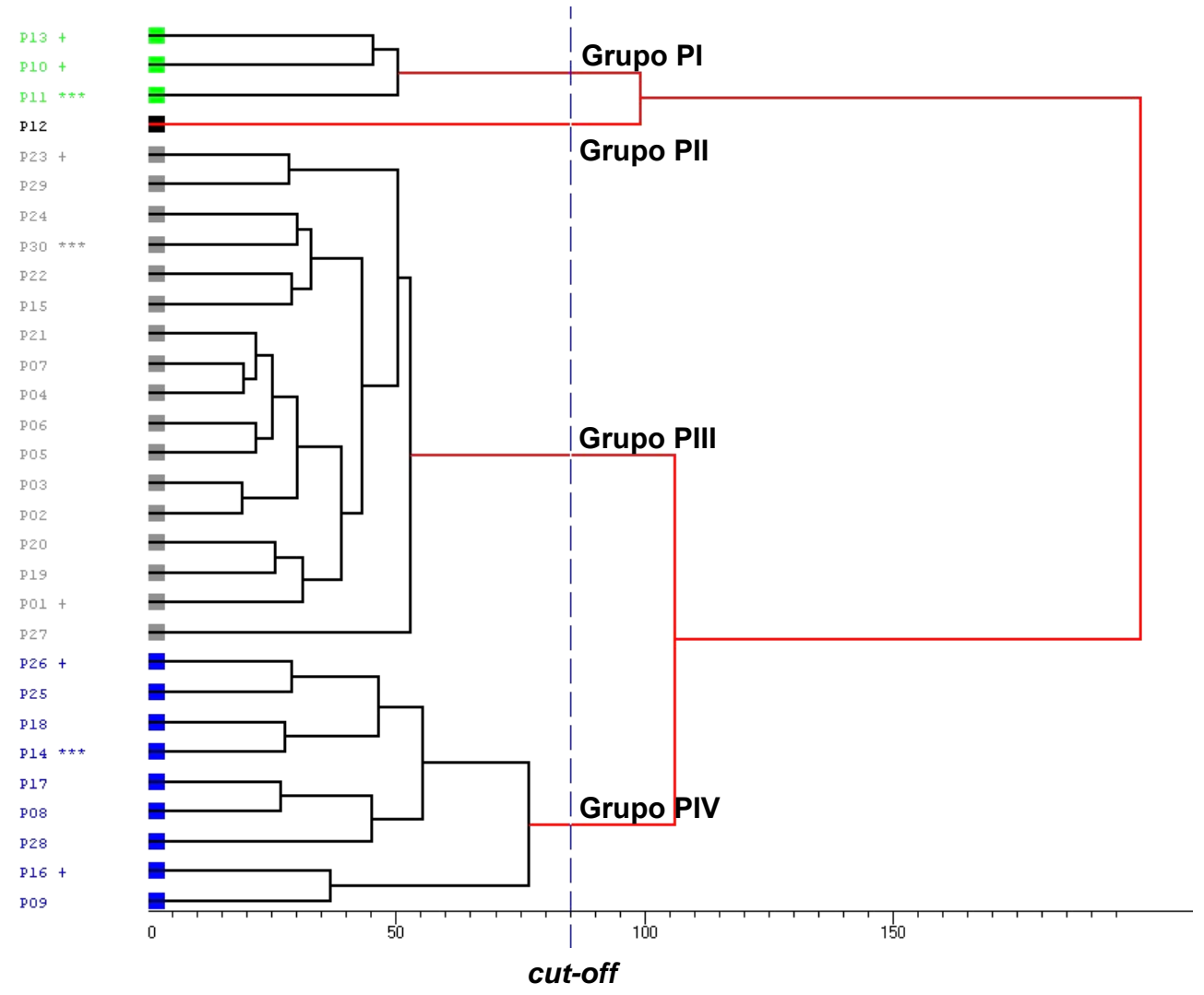

Figura 32 - Dendograma da análise por agrupamento das amostras da pesquisa mineral (P), segundo um cut-off de 85 .

Os denominados Grupos PI e Pll são pouco expressivos no universo amostrado, visto que o primeiro é composto por três amostras, enquanto que o segundo é representado por apenas uma (P12).

O Grupo PIII refere-se ao de maior representatividade, contendo 17 amostras (57\% do total) de aspectos bastante homogêneos entre si. Nota-se, porém, a existência de subgrupos dentro deste, os quais poderiam ser trabalhados separadamente no caso de um estudo mais aprofundado das dissimilaridades entre as amostras. Este mesmo comportamento, e com dissimilaridades mais aparentes, é 
observado para o Grupo PIV, representado por um número também considerável de amostras (9).

O diagrama de análise do componente principal (PCA), relativo aos três primeiros valores de Eigenvalues plotados em gráfico 3D para as amostras $P$, é apresentado na Figura 33, sendo que na Figura 34 são destacados os difratogramas das amostras representativas de cada um dos grupos, possibilitando uma melhor visualização das diferenças entre os mesmos.

Para a determinação da composição mineralógica e conseqüente aferição da análise por DRX-Rietveld foram selecionadas sete amostras de forma a abranger as variações de composição observadas, sendo elas:

- Grupo PI - amostra P13;

- Grupo PII - amostra P12;

- Grupo PIII - amostras P20 e P29;

- Grupo PIV - amostras P17, P18 e P26.

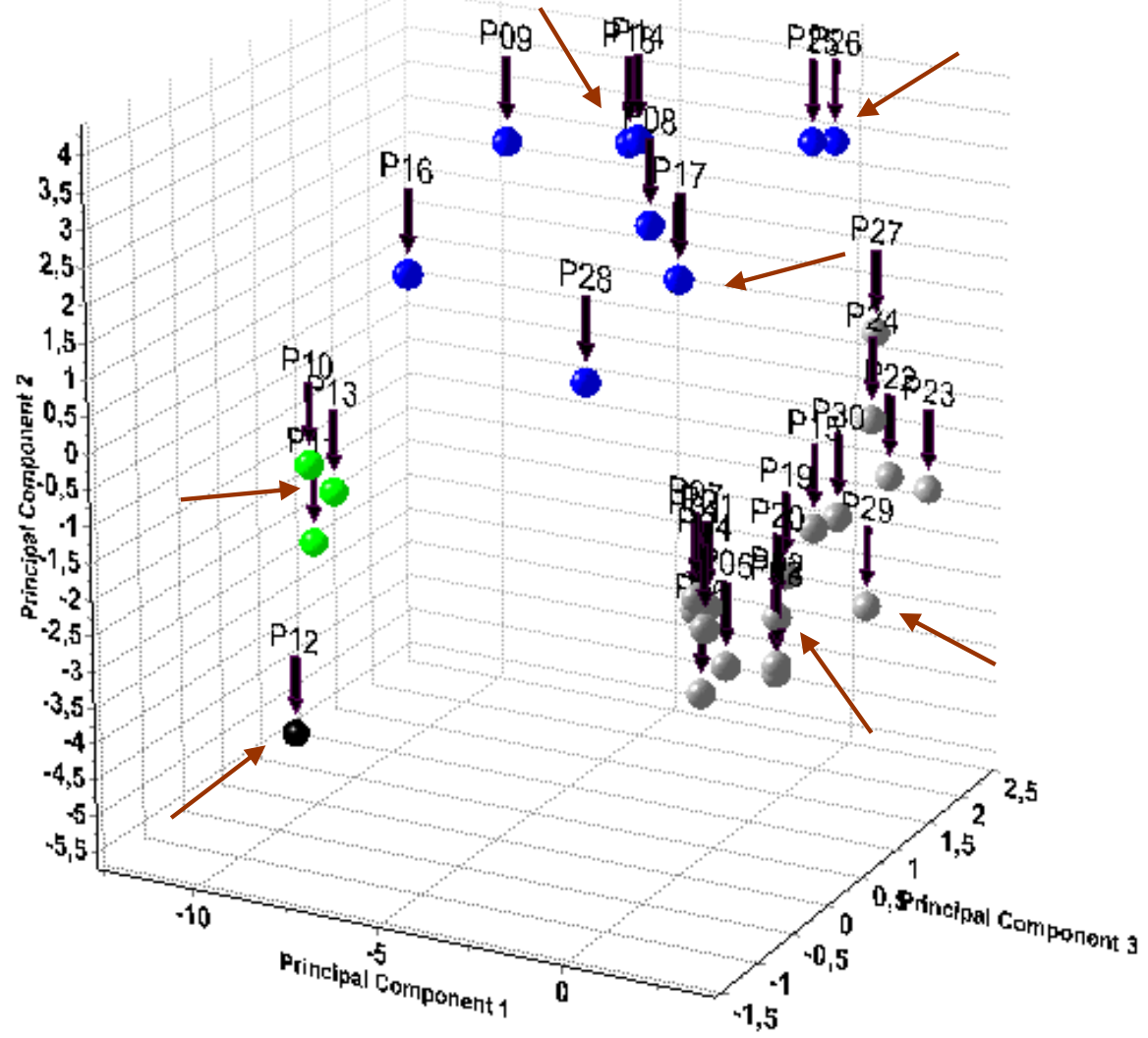

Figura 33 - Diagrama de análise do componente principal (três primeiros Eigenvalues) das amostras da pesquisa mineral $(\mathrm{P})$; destaque para as amostras selecionadas como representantes da variabilidade mineralógica 


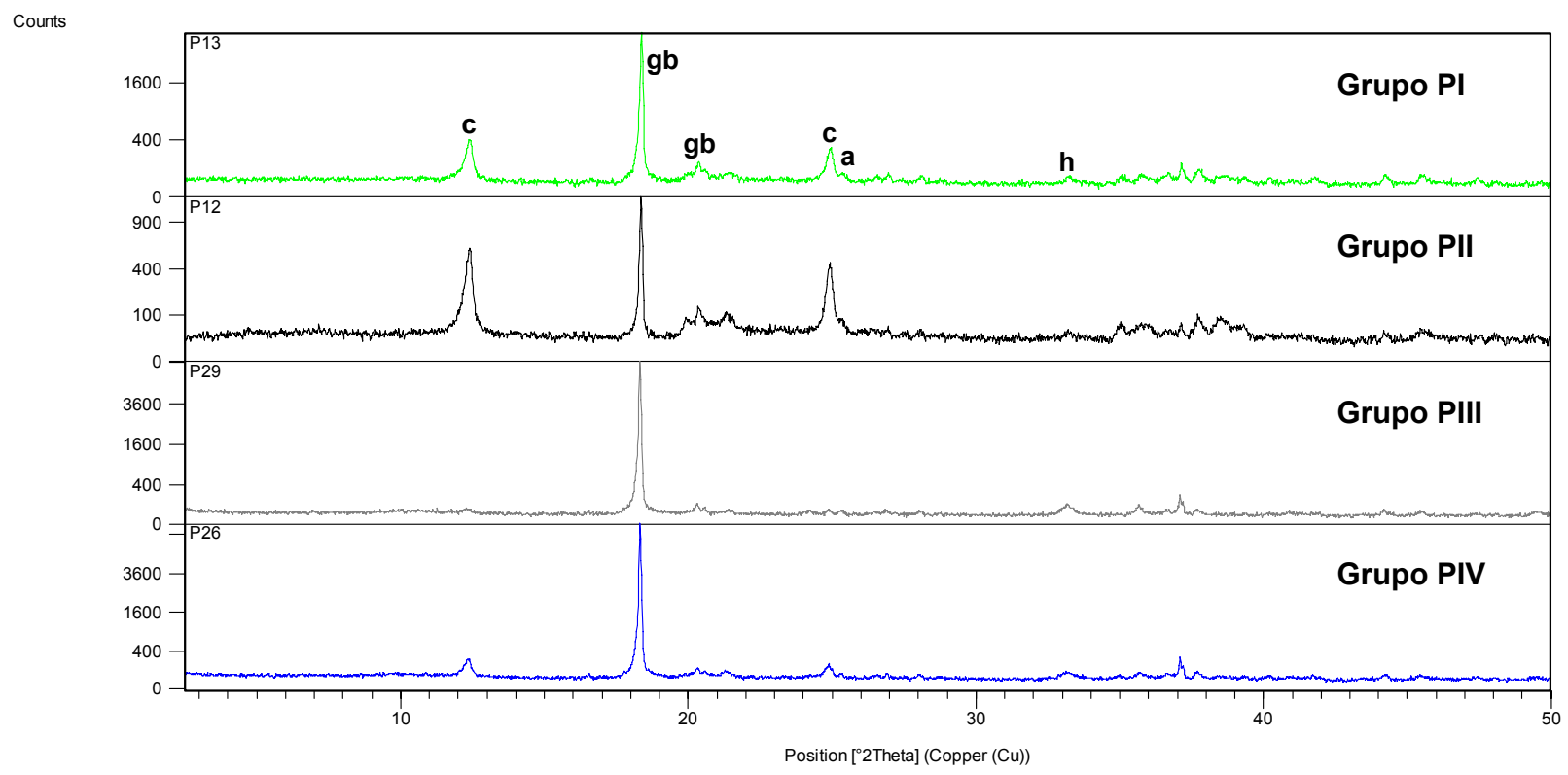

Figura 34 - Comparação entre difratogramas de amostras representantes de cada grupo

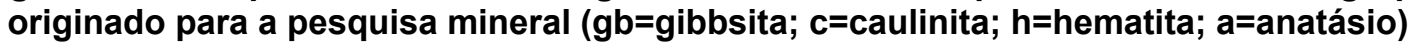

Observa-se que os agrupamentos diferem-se pelas proporções de minerais presentes, visto que ocorrem nítidas variações de intensidades relativas de conjuntos de picos representantes das fases (comuns para todo o universo amostral). A Figura 35 apresenta os agrupamentos confrontados com os resultados de análises químicas das amostras.

Com relação aos teores de $\mathrm{Al}_{2} \mathrm{O}_{3}$ total correlacionados aos de $\mathrm{Al}_{2} \mathrm{O}_{3}$ aproveitável e $\mathrm{SiO}_{2}$ total, notam-se duas tendências principais de associação de elementos / composição mineral, referentes aos conteúdos de gibbsita e/ou argilominerais nas amostras.

A correlação para $\mathrm{Al}_{2} \mathrm{O}_{3}$ não aproveitável e $\mathrm{SiO}_{2}$ reativa é bastante definida e corresponde a relação de elementos na composição dos argilominerais, sendo claramente observadas as diferentes tendências de concentração desses minerais nos grupos de amostras definidos. Os teores de $\mathrm{Fe}_{2} \mathrm{O}_{3}$ não apresentam comportamento claramente definido. 

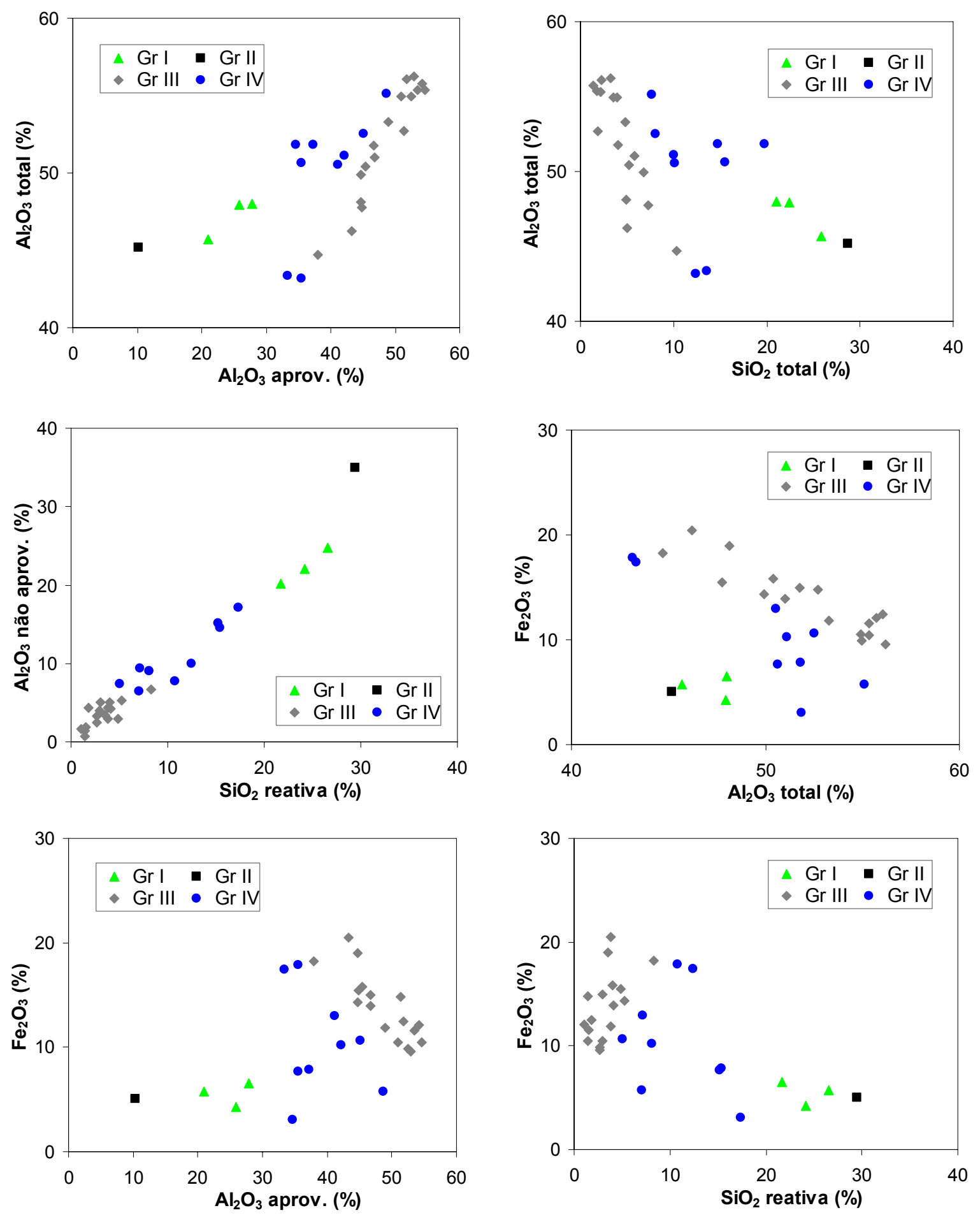

Figura 35 - Diferenciação entre agrupamentos de amostras da pesquisa mineral (P) em função de suas características químicas 
O dendograma obtido para as amostras $U$ é apresentado na Figura 36 e ilustra o agrupamento dessas amostras em dois conjuntos de semelhança.
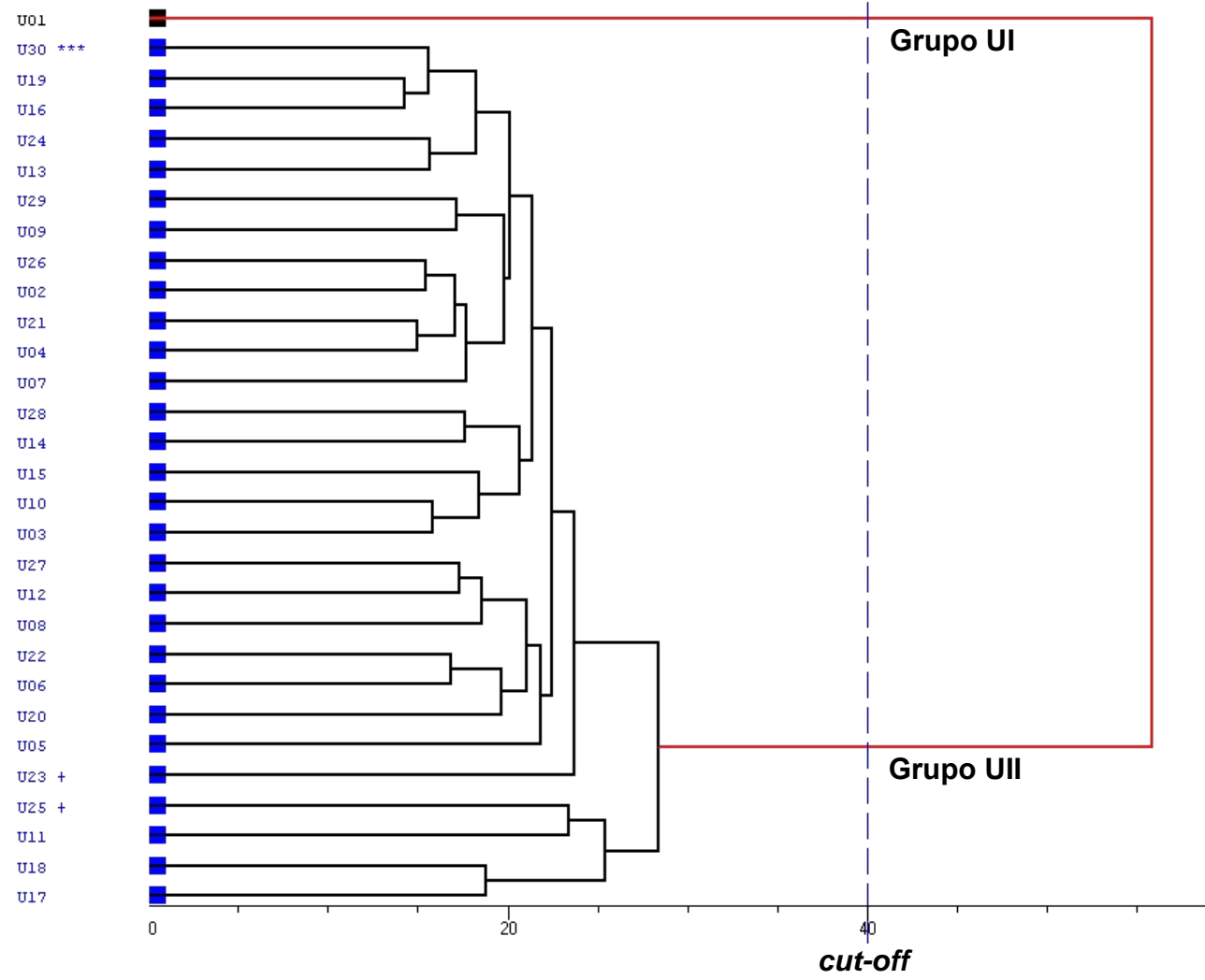

Figura 36 - Dendograma da análise por agrupamento dos produtos de beneficiamento (U), segundo um cut-off de 40.

O denominado Grupo UI é inexpressivo no universo amostrado, visto que é constituído por apenas uma amostra, enquanto que o Grupo UII refere-se ao de maior representatividade, contendo 29 amostras (97\% do total) com aspectos bastante homogêneos entre si, apesar de também apresentar subgrupos de semelhanças quando analisado em maior detalhe.

O diagrama de análise do componente principal (PCA), relativo aos três primeiros valores de Eigenvalues plotados em gráfico 3D para as amostras $U$, é apresentado na Figura 37, sendo que na Figura 38 são comparados os difratogramas representativos de cada um dos grupos originados, possibilitando uma melhor visualização de suas diferenças.

Desta forma, para a avaliação das proporções minerais foram selecionadas três amostras, sendo todas pertencentes ao Grupo UII - amostra U06, U13 e U21. 


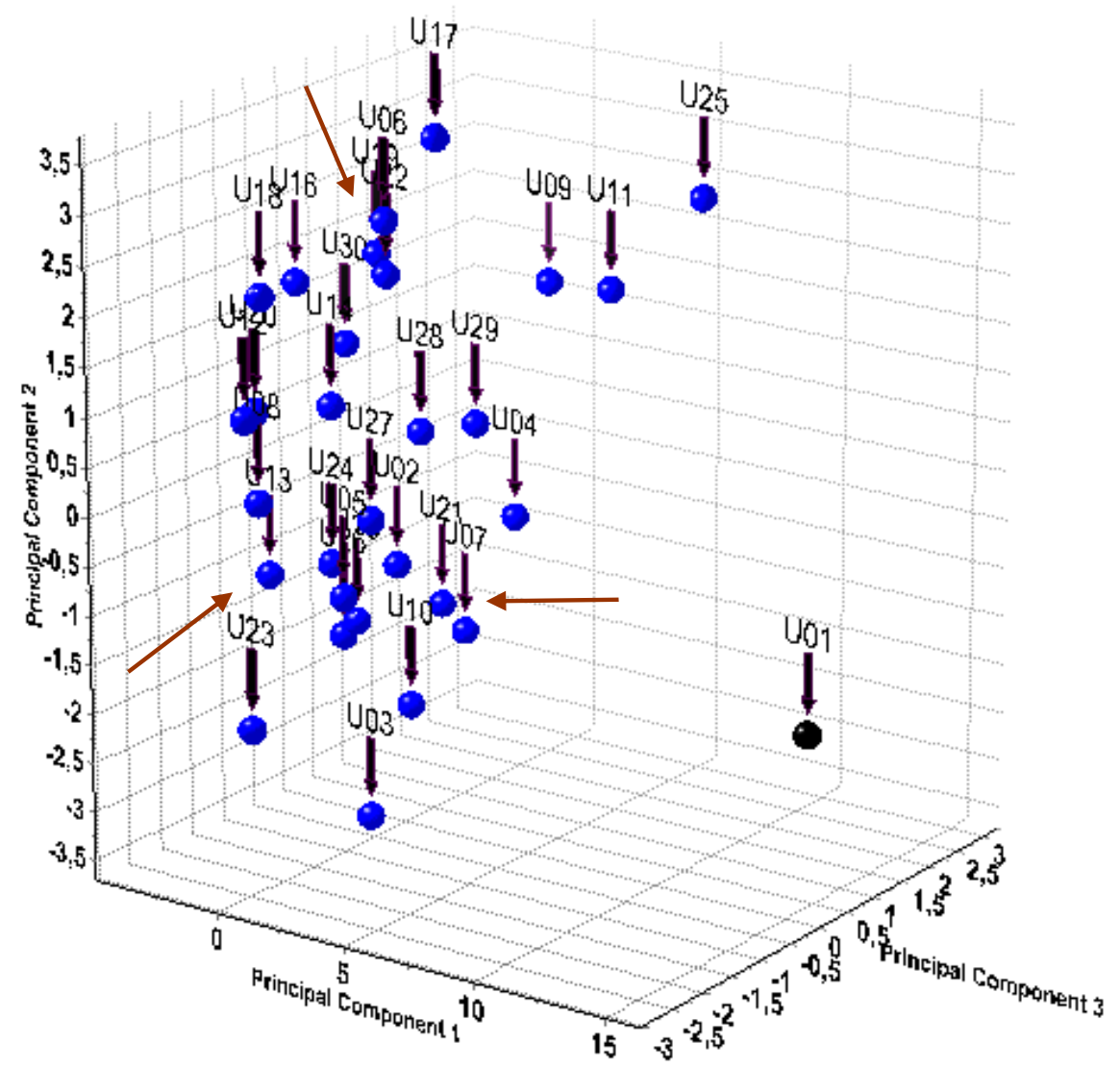

Figura 37 - Diagrama de análise do componente principal (três primeiros Eigenvalues) das amostras dos produtos de beneficiamento (U); destaque para as amostras selecionadas como representantes da variabilidade mineralógica

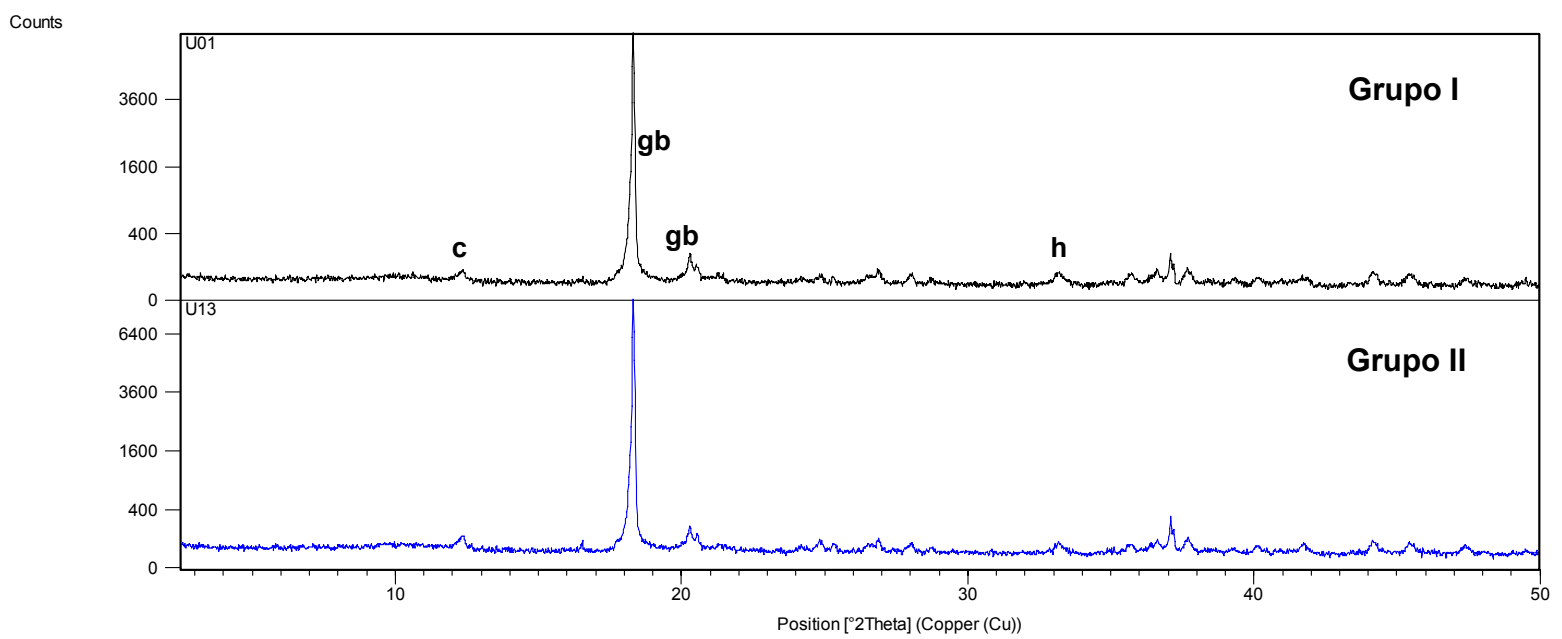

Figura 38 - Comparação de difratogramas representativos de cada grupo originado dentre as

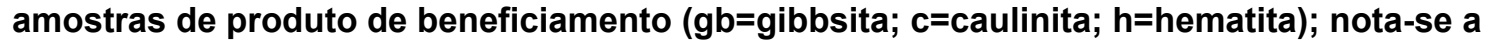
extrema semelhança entre eles

A análise por agrupamento evidencia resultados já esperados, visto que as amostras $U$ são produtos de processo de beneficiamento, com características 
controladas, sendo observadas, portanto, grande similaridade entre elas. A amostra U01, porém, mostrou-se distinta das demais pelo recurso de análise por agrupamento; entretanto, nenhuma variação foi identificada em seu padrão difratométrico que corrobore com tal discriminação, assim como em sua composição química, conforme a Figura 39.
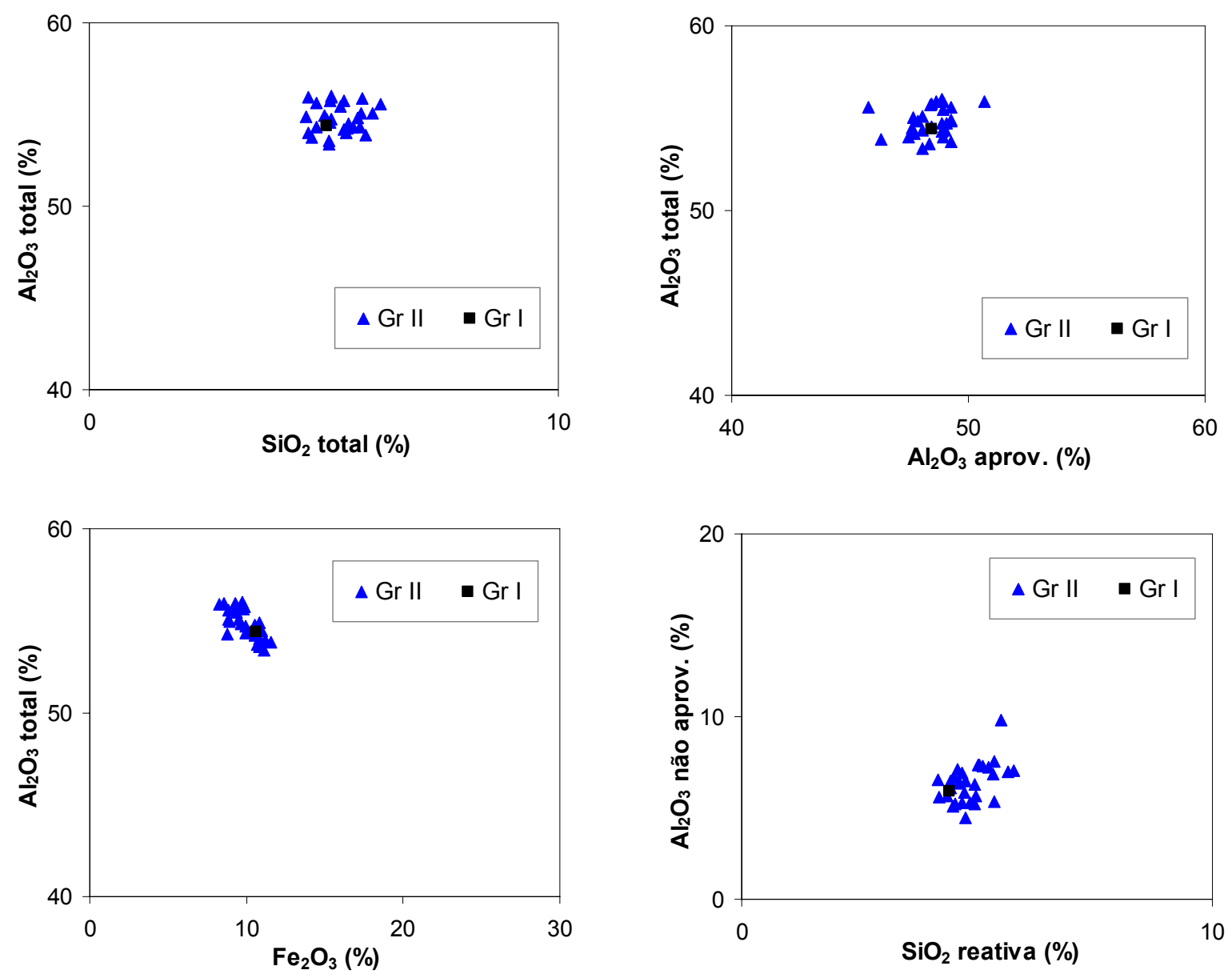

Figura 39 - Diagramas de correlação de teores para produtos do beneficiamento

As amostras $\mathrm{U}$ contêm elevados teores de $\mathrm{Al}_{2} \mathrm{O}_{3} \quad(\sim 55 \%)$, relacionados essencialmente a $\mathrm{Al}_{2} \mathrm{O}_{3}$ aproveitável, e menores quantidades de $\mathrm{Fe}_{2} \mathrm{O}_{3}(\sim 10 \%)$ e de $\mathrm{SiO}_{2}(\sim 5 \%)$ na forma de $\mathrm{SiO}_{2}$ reativa. 


\subsection{Determinação das proporções minerais}

Nas amostras selecionadas como representativas da variabilidade composicional dentre as 60 amostras analisadas (item 4.2), foram efetuadas determinações das proporções minerais por caracterização mineralógica tradicional, espectroscopia Mössbauer e DRX-Rietveld, considerando preferencialmente variações das proporções dos maiores constituintes (gibbsita, argilominerais e óxidos de ferro).

\subsubsection{Caracterização mineralógica}

A caracterização mineralógica das amostras envolveu etapas de classificação granulométrica e separação em líquido denso, apoiadas por análise química e mineral, propiciando a obtenção da estimativa mineralógica por meio de cálculos estequiométricos.

\subsubsection{Classificação granulométrica}

Os resultados de distribuição de teores por fração granulométrica para as amostras selecionadas são apresentados na Tabela 5 em conjunto com os teores dosados pela MRN para simples comparação.

Os materiais da pesquisa mineral mostraram porcentagem em massa passante em 0,037 $\mathrm{mm}$ variando em amplo espectro (31,2 a 80,6\% em massa), enquanto que para os produtos da usina beneficiamento o mesmo se limita a porcentagens de 26,3 a $30,9 \%$.

$\mathrm{O} \mathrm{Al}_{2} \mathrm{O}_{3}$ total é o constituinte principal nas amostras, variando entre $40,4 \mathrm{e}$ $55,8 \%$ da composição das mesmas. Concentra-se preferencialmente na fração $+0,037 \mathrm{~mm}$ ( $>62 \%$ do total contido na amostra), fração essa que também mostra a maior parcela de alumina aproveitável ( $>77 \%$ do total contido na amostra). Como exceção tem-se a amostra $\mathrm{P} 12$, com $72,6 \%$ de $\mathrm{Al}_{2} \mathrm{O}_{3}$ total contido em $-0,037 \mathrm{~mm}$ (essencialmente alumina não aproveitável). 
Tabela 5 - Resultados de classificação granulométrica

\begin{tabular}{|c|c|c|c|c|c|c|c|c|c|c|c|c|c|c|c|}
\hline \multirow{2}{*}{ Amostra } & \multirow{2}{*}{$\begin{array}{c}\text { Fração } \\
\text { (mm) }\end{array}$} & \multirow{2}{*}{$\begin{array}{c}\% \\
\text { Massa } \\
\text { retida }\end{array}$} & \multicolumn{7}{|c|}{ Teores (\%) } & \multicolumn{6}{|c|}{ Distribuição no ensaio (\%) } \\
\hline & & & $\mathrm{Al}_{2} \mathrm{O}_{3}$ & $\mathrm{SiO}_{2}$ & $\mathrm{Fe}_{2} \mathrm{O}_{3}$ & $\mathrm{TiO}_{2}$ & PF & $\mathrm{Al}_{2} \mathrm{O}_{3 a p}$ & $\mathrm{SiO}_{2 \mathrm{re}}$ & $\mathrm{Al}_{2} \mathrm{O}_{3}$ & $\mathrm{SiO}_{2}$ & $\mathrm{Fe}_{2} \mathrm{O}_{3}$ & $\mathrm{TiO}_{2}$ & $\mathrm{Al}_{2} \mathrm{O}_{3 \text { ар }}$ & $\mathrm{SiO}_{2 \mathrm{re}}$ \\
\hline \multirow{4}{*}{ P12 } & & 19,4 & 57,1 & 9,42 & 3,47 & 1,11 & 29,8 & 48,5 & 9,30 & 27,4 & 5,3 & 12,9 & 10,9 & 79,0 & 5,3 \\
\hline & $-0,037$ & 80,6 & 36,4 & 40,5 & 5,63 & 2,18 & 15,3 & 3,10 & 40,0 & 72,6 & 94,7 & 87,1 & 89,1 & 21,0 & 94,7 \\
\hline & Total calc. & 100 & 40,4 & 34,5 & 5,21 & 1,97 & 18,1 & 11,9 & 34,0 & 100,0 & 100,0 & 100,0 & 100,0 & 100,0 & 100,0 \\
\hline & Total MRN & & 45,2 & 28,7 & 5,04 & 2,06 & $\ldots$ & 10,3 & 29,5 & & & & & & \\
\hline \multirow{4}{*}{ P13 } & $+0,037$ & 49,3 & 58,1 & 7,20 & 4,16 & 1,01 & 29,5 & 48, & 6,80 & 61,6 & 16,7 & 29,0 & & 0 & 17,2 \\
\hline & $-0,037$ & 50,7 & 35,3 & 35,0 & 9,91 & 2,87 & 16,4 & 8,58 & 31,9 & 38,4 & 83,3 & 71,0 & 74,5 & 15,5 & 82,8 \\
\hline & Tota & 100 & 46,6 & 21,3 & 7,08 & 1,95 & 22,9 & 28,1 & 19,5 & 100,0 & 100,0 & 100,0 & 100,0 & 100,0 & 100,0 \\
\hline & Total MRN & & 48,0 & 21,0 & 6,51 & 2,16 & $\ldots$ & 27,9 & 21,7 & & & & & & \\
\hline \multirow{4}{*}{ P17 } & + & 68,7 & 58,2 & 3,65 & 7,53 & 0,79 & 30,5 & 54,9 & 2,57 & 76,5 & 32,7 & 46,2 & 33,4 & 31,9 & 27,6 \\
\hline & $-0,037$ & 31,3 & 39,3 & 16,5 & 19,2 & 3,45 & 21,1 & 26,7 & 14,8 & 23,5 & 67,3 & 53,8 & 66,6 & 18,1 & 72,4 \\
\hline & Total calc. & 100 & 52,3 & 7,68 & 11,2 & 1,62 & 27,6 & 46,1 & 6,40 & 100,0 & 100,0 & 100,0 & 100,0 & 100,0 & 100,0 \\
\hline & Tot & & 52,5 & 8,01 & 10,6 & 1,86 & $\ldots$ & 45,1 & 5,02 & & & & & & \\
\hline \multirow{4}{*}{ P18 } & $+0,037$ & 53,4 & 60,4 & 3,85 & 4,95 & 0,63 & 31,5 & 55,4 & 3,40 & 63,1 & 13,8 & 32,5 & 18,3 & 80,3 & 12,4 \\
\hline & $-0,037$ & 46,6 & 40,5 & 27,6 & 11,8 & 3,21 & 18,9 & 15,5 & 27,4 & 36,9 & 86,2 & 67,5 & 81,7 & 19,7 & 87,6 \\
\hline & Tota & 100 & 51,1 & 14,9 & 8,13 & 1,83 & 25,6 & 36,8 & 14,6 & 100,0 & 100,0 & 100,0 & 100,0 & 100,0 & 100,0 \\
\hline & Tot & & 51,8 & 14,7 & 7,85 & 1,90 & $\ldots$ & 37 & 5,4 & & & & & & \\
\hline \multirow{4}{*}{ P20 } & $+0,037$ & 68,8 & 56,5 & 2,36 & 10,2 & 1,77 & 30,4 & 52,9 & 1,72 & 75,0 & 40,1 & 47,1 & 52 & 77,3 & 33,8 \\
\hline & $-0,037$ & 31,2 & 41,5 & 7,74 & 25,1 & 3,55 & 23,9 & 34,2 & 7,43 & 25,0 & 59,9 & 52,9 & 47,7 & 22,7 & 66,2 \\
\hline & Total calc. & 100 & 51,8 & 4,04 & 14,8 & 2,33 & 28,3 & 47,0 & 3,51 & 100,0 & 100,0 & 100,0 & 100,0 & 100,0 & 100,0 \\
\hline & Total MRN & & 51,8 & 4,01 & 15,0 & 2,47 & 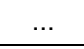 & 46,7 & 3,00 & & & & & & \\
\hline \multirow{4}{*}{ P26 } & $+0,037$ & 60,5 & 52,6 & 4,38 & 13,4 & 0,79 & 28,7 & 50,6 & 3,43 & 71,1 & 20,5 & 49,4 & 28,2 & 85,9 & 17,2 \\
\hline & $-0,037$ & 39,5 & 32,7 & 26,0 & 20,9 & 3,09 & 16,8 & 12,8 & 25,3 & 28,9 & 79,5 & 50,6 & 71,8 & 14,1 & 82,8 \\
\hline & Total calc. & 100 & 44,8 & 12,9 & 16,3 & 1,70 & 24,0 & 35,7 & 12,0 & 100,0 & 100,0 & 100,0 & 100,0 & 100,0 & 100,0 \\
\hline & Total MRN & & 43,2 & 12,4 & 17,9 & 1,91 & $\ldots$ & 35.5 & 10,8 & & & & & & \\
\hline \multirow{4}{*}{ P29 } & $+0,037$ & 60,5 & 54,9 & 2,30 & 12,7 & 1,07 & 29,5 & 52,8 & 1,72 & 71,1 & 20,5 & 49,4 & 28,2 & 85,9 & 17,2 \\
\hline & $-0,037$ & 39,5 & 30,9 & 9,35 & 39,2 & 4,04 & 17,4 & 22,0 & 9,06 & 28,9 & 79,5 & 50,6 & 71,8 & 14,1 & 82,8 \\
\hline & Total calc. & 100 & 47,8 & 4,40 & 20,6 & 1,95 & 25,9 & 43,6 & 3,90 & 100,0 & 100,0 & 100,0 & 100,0 & 100,0 & 100,0 \\
\hline & Total MRN & & 46,2 & 5,02 & 20,5 & 2,21 & $\ldots$ & 43,3 & 3,85 & & & & & & \\
\hline & $+0,037$ & 73,7 & 57,5 & 4,22 & 8,42 & 1,22 & 30,6 & 53,0 & 3,37 & 78,1 & 57,6 & 54,0 & 58,0 & 78,6 & 53,8 \\
\hline & $-0,037$ & 26,3 & 45,1 & 8,72 & 20,1 & 2,48 & 24,3 & 36,7 & 8,13 & 21,9 & 42,4 & 46,0 & 42,0 & 21,4 & 46,2 \\
\hline & Total calc. & 100 & 54,2 & 5,41 & 11,5 & 1,55 & 28,9 & 48,7 & 4,62 & 100,0 & 100,0 & 100,0 & 100,0 & 100,0 & 100,0 \\
\hline & Tote & & 53,6 & 5,11 & 10,8 & 1,58 & $\ldots$ & 48,4 & 4,94 & & & & & & \\
\hline \multirow{4}{*}{ U13 } & $+0,037$ & 69,1 & 58,3 & 4,97 & 5,44 & 1,24 & 30,6 & 30 & 2 & 72,8 & 51,4 & 47,2 & 52,0 & 76,5 & 69,8 \\
\hline & $-0,037$ & 30,9 & 47,0 & 9,02 & 13,6 & 2,56 & 24,6 & 36,4 & 8,10 & 27,2 & 48,6 & 52,8 & 48,0 & 23,5 & 30,2 \\
\hline & Total calc. & 100 & 54,8 & 6,22 & 7,95 & 1,65 & 28,8 & 47,8 & 5,21 & 100,0 & 100,0 & 100,0 & 100,0 & 100,0 & 100,0 \\
\hline & Total MRN & & 55,6 & 6,21 & 8,82 & 1,59 & $\ldots$ & 45,8 & 5,90 & & & & & & \\
\hline \multirow{4}{*}{ U21 } & $+0,037$ & 71,6 & 59,0 & 4,07 & 6,63 & 1,14 & 31,0 & 04,0 & J, & 75,7 & 51,3 & 49,6 & 52,4 & 78,7 & 47,9 \\
\hline & $-0,037$ & 28,4 & 47,7 & 9,74 & 17,0 & 2,61 & 24,6 & 37,1 & 9,11 & 24,3 & 48,7 & 50,4 & 47,6 & 21,3 & 52,1 \\
\hline & Total calc. & 100 & 55,8 & 5,69 & 9,58 & 1,56 & 29,2 & 49,5 & 4,97 & 100,0 & 100,0 & 100,0 & 100,0 & 100,0 & 100,0 \\
\hline & Total MRN & & 55,9 & 4,68 & 8,55 & 1,53 & $\ldots$ & 50,7 & 4,54 & & & & & & \\
\hline
\end{tabular}

Obs: teores destacados em azul indicam desvios analíticos superiores a 10\% relativos entre valores dosado e calculado;

$\ldots=$ dados não disponíveis 
Os teores de $\mathrm{SiO}_{2}$ total nas amostras são variáveis, sendo mínimo na amostra P20 (4,04\%) e máximo na amostra P12 (34,5\%); apresentam-se principalmente na forma de $\mathrm{SiO}_{2}$ reativa e aumentam em direção aos finos.

Os teores de $\mathrm{Fe}_{2} \mathrm{O}_{3}$ variam entre 5,21 e 20,6\% e aparecem mais elevados na fração abaixo de 0,037 mm. Comportamento semelhante é verificado para o $\mathrm{TiO}_{2}$ que, apesar de mostrar teores discretos, entre 1,55-2,33\%, concentra-se também nos finos. Valores de perda ao fogo variam entre 18,1 e $29,2 \%$.

\subsubsection{Separação em líquido denso}

Os resultados da distribuição de teores nos produtos da separação mineral realizada na fração retida em $0,037 \mathrm{~mm}$ das amostras estão expostos na Tabela 6.

O produto flutuado varia de 73,7 a 95,8\% em massa no ensaio, com exceção da amostra P29 que apresenta apenas 58,1\%. Amostras da usina apresentam em média $82 \%$ em massa de produto flutuado.

Os teores de $\mathrm{Al}_{2} \mathrm{O}_{3}$ neste produto variam de 58,9 a $62,4 \%$ nas amostras (>80\% do total contido nos ensaios; $>60 \%$ do total contido nas amostras) e estão relacionados preferencialmente ao $\mathrm{Al}_{2} \mathrm{O}_{3}$ aproveitável; destaca-se, entretanto, a amostra P12 na qual esse teor equivale a apenas $26,9 \%$ do total contido na mesma, enquanto que para a P29, refere-se a 65,2 e 52,6\%, respectivamente, o total contido no ensaio e na amostra.

Os teores de $\mathrm{SiO}_{2}$ neste produto compreendem valores entre 1,86 e 9,60\% nas amostras ( $>70 \%$ do total contido nos ensaios; $>12,7 \%$ do total contido nas mesmas) e estão relacionados preferencialmente $\mathrm{a} \mathrm{SiO}_{2}$ reativa; destacam-se como exceções o produto flutuado da amostra P12 que apresenta apenas 5\% do total de $\mathrm{SiO}_{2}$ contido na mesma e a P29, onde este valor refere-se a $50 \%$ do total do ensaio.

Os teores de $\mathrm{Fe}_{2} \mathrm{O}_{3}$ no produto flutuado das amostras variam entre 1,87$3,83 \%$, enquanto que os teores de $\mathrm{TiO}_{2}$ variam entre $0,58-1,60 \%$.

O produto afundado da fração retida em $0,037 \mathrm{~mm}$ varia de 4,2 a $26,3 \% \mathrm{em}$ massa no ensaio, porém na amostra P29 este valor é elevado a 41,9\%; amostras da usina apresentam em média $18 \%$ em massa de produto afundado. 


\begin{tabular}{|c|c|c|c|c|c|}
\hline 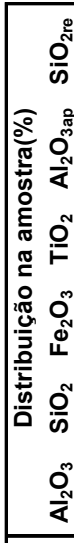 & 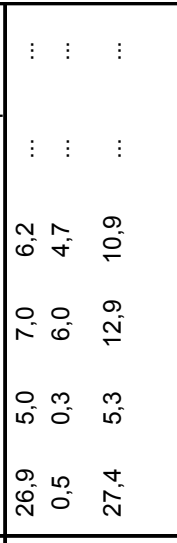 & 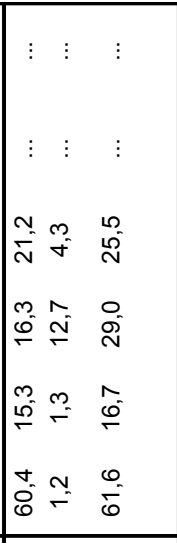 & 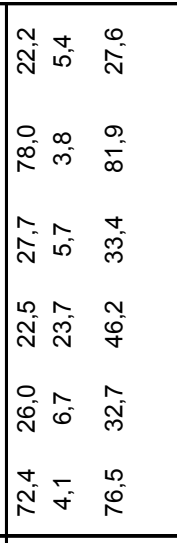 & 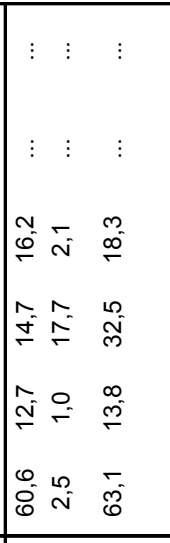 & 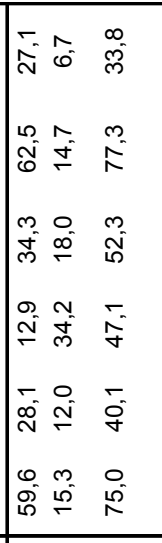 \\
\hline 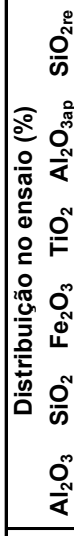 & 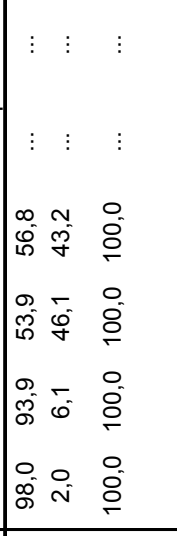 & 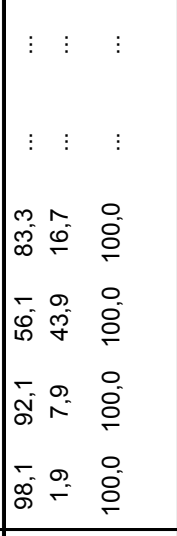 & 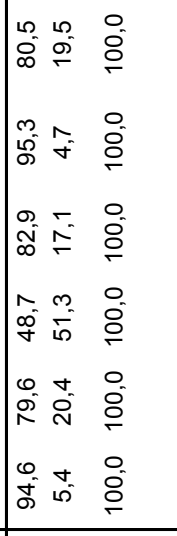 & 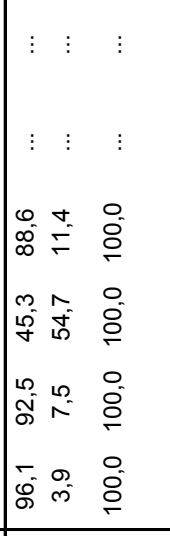 & 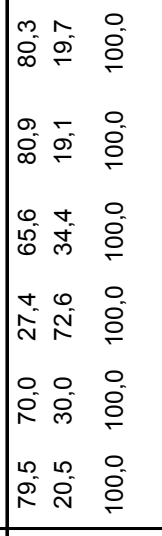 \\
\hline 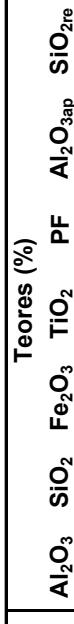 & 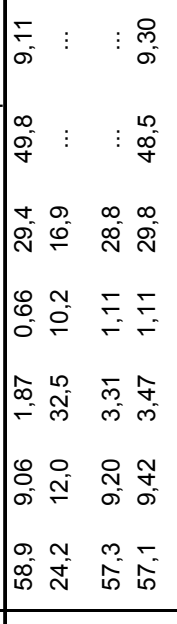 & 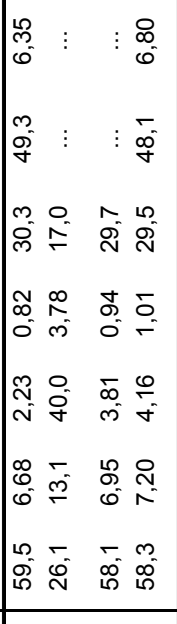 & 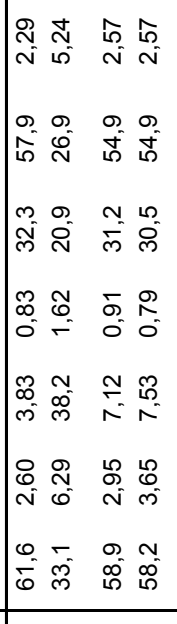 & 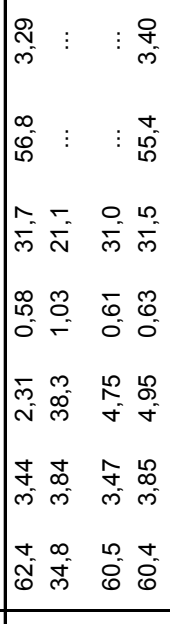 & 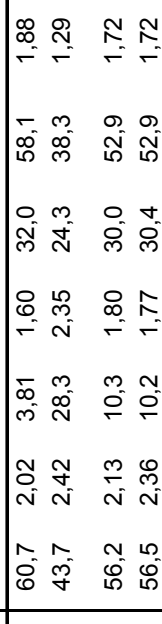 \\
\hline 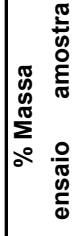 & 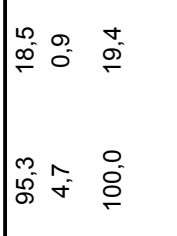 & 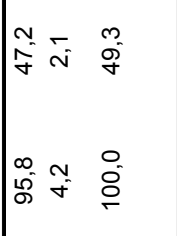 & 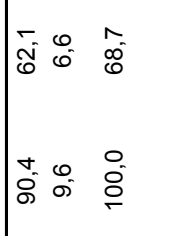 & 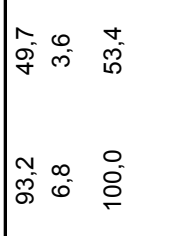 & 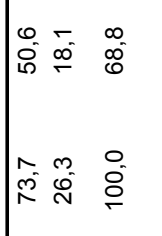 \\
\hline 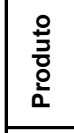 & 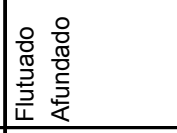 & 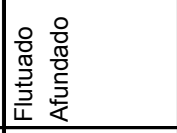 & 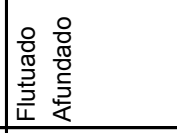 & 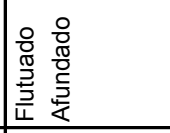 & 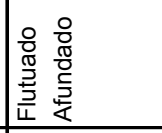 \\
\hline 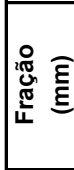 & 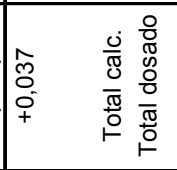 & 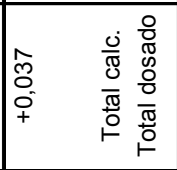 & 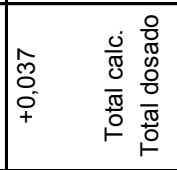 & 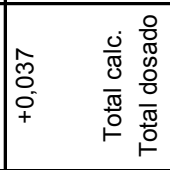 & 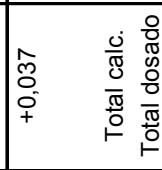 \\
\hline 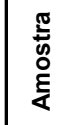 & $\grave{\Lambda}$ & $\grave{c}_{0}^{m}$ & $\hat{\grave{a}}$ & $\stackrel{\infty}{\alpha}$ & $\tilde{\Sigma}$ \\
\hline
\end{tabular}




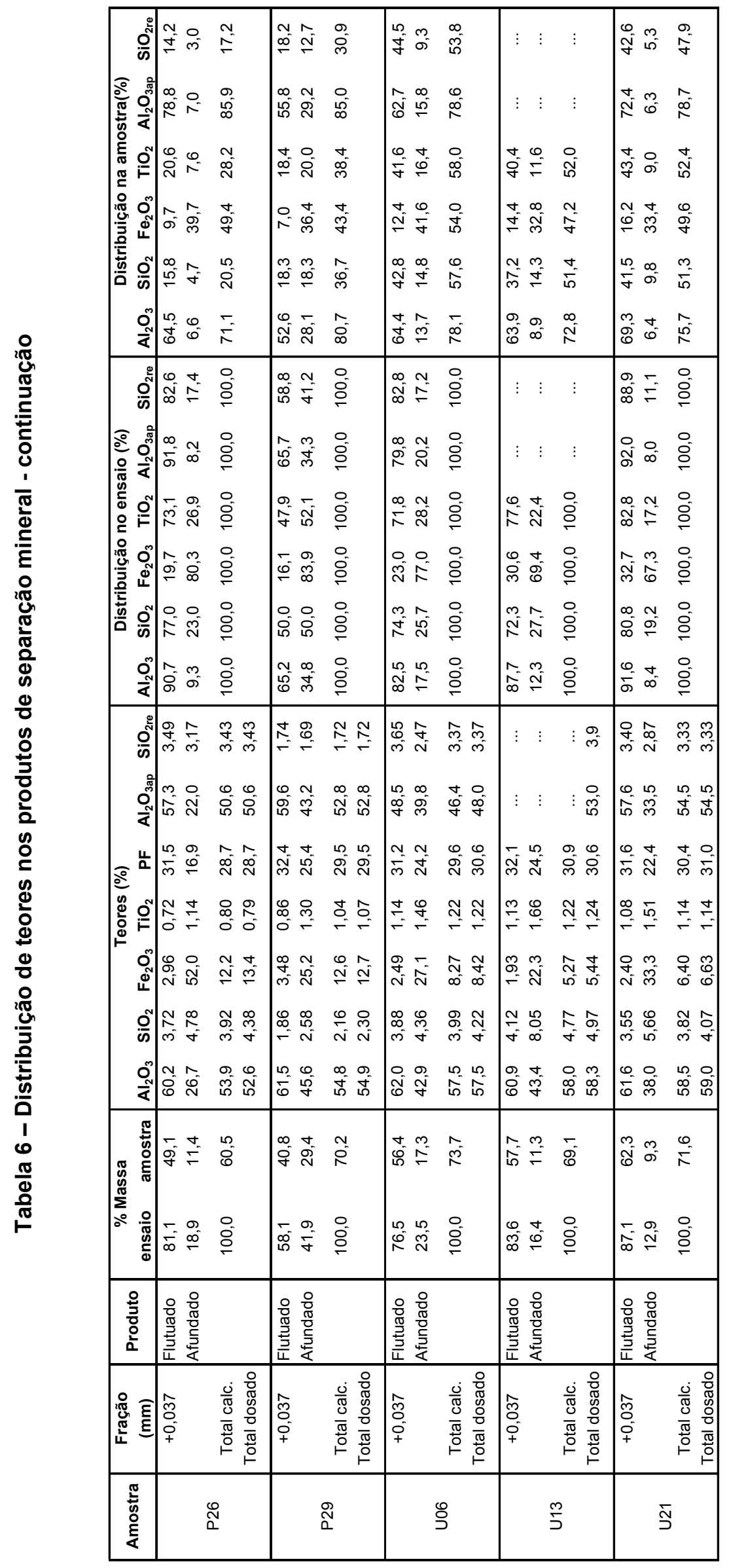


Os teores de $\mathrm{Al}_{2} \mathrm{O}_{3}$ neste produto variam de 24,2 a 45,6\% e representam de 0,5 a $28 \%$ do total contido nas amostras, relacionados preferencialmente a $\mathrm{Al}_{2} \mathrm{O}_{3}$ aproveitável. Especificamente, as amostras da usina apresentam em média 41,4\% de $\mathrm{Al}_{2} \mathrm{O}_{3}$ total neste produto (média de $12,7 \%$ do total contido no ensaio e de $9,67 \%$ do total contido na amostra).

Os teores de $\mathrm{SiO}_{2}$ total compreendem a valores entre 2,42 e 13,1\% e representam de 0,3 a $18,3 \%$ do total contido nas amostras, relacionados preferencialmente a $\mathrm{SiO}_{2}$ reativa. Os teores de $\mathrm{Fe}_{2} \mathrm{O}_{3}$ no produto afundado das amostras variam entre 22,3 e $52 \%$, enquanto que os teores de $\mathrm{TiO}_{2}$ variam entre 1,03 e $10,2 \%$.

\subsubsection{Estimativa da composição mineralógica}

A Tabela 7 e Figura 40 apresentam a estimativa das proporções minerais, efetuada a partir da conjugação de análises granulométricas, separações minerais, análises químicas, DRX e MEV, além de cálculos estequiométricos baseados em composições minerais teóricas.

A gibbsita varia entre 47 a $79 \%$ nas amostras, com exceção da P12 que apresenta apenas 19\%; aparece contida principalmente no produto flutuado da fração retida em $0,037 \mathrm{~mm}$.

A proporção de caulinita é bastante variável entre as amostras, representando de 7 a 42\% das mesmas e atingindo o máximo de 73\% na P12. Aparece contida preferencialmente na fração passante em $0,037 \mathrm{~mm}$ e representa a alumina não aproveitável juntamente com a sílica reativa.

Os óxidos e hidróxidos de ferro (hematita e goethita) representam de 5 a $20 \%$ das amostras e estão contidos principalmente na fração abaixo de 0,037 mm, aparecendo também no produto afundado da fração acima de 0,037 mm. De maneira semelhante estão os minerais de titânio (anatásio), porém representando cerca de $2 \%$ de todas as amostras.

A porcentagem de quartzo nas amostras é igual ou inferior a $1 \%$, sendo que o mineral aparece contido na fração passante em 0,037 mm e, muito restritamente, como traço no produto afundado da fração retida em $0,037 \mathrm{~mm}$. 
As amostras da usina de beneficiamento se mostraram bastante semelhantes, o que já havia sido observado na análise por agrupamento. Apresentam em média $78 \%$ de gibbsita, $11 \%$ de caulinita, $9 \%$ de minerais de ferro, $2 \%$ de minerais de titânio e $1 \%$ de quartzo.

Tabela 7 - Estimativa mineralógica apoiada em procedimentos de caracterização mineral

\begin{tabular}{|c|c|c|c|c|c|c|c|}
\hline Amostra & $\begin{array}{c}\text { Fração } \\
\text { (mm) }\end{array}$ & $\%$ Massa & Gibbsita & Caulinita & $\begin{array}{l}\text { \% Mineral } \\
\text { Óxi-hidr.Fe }\end{array}$ & Anatásio & Quartzo \\
\hline \multirow{3}{*}{ P12 } & $+0,037$ & 19,4 & 77 & 20 & 3 & 1 & 0,1 \\
\hline & $-0,037$ & 80,6 & 5 & 85 & 6 & 2 & 1 \\
\hline & Total calculado & 100,0 & 19 & 73 & 5 & 2 & 0,4 \\
\hline \multirow{3}{*}{ P13 } & $+0,037$ & 49,3 & 81 & 14 & 4 & 1 & 0,4 \\
\hline & $-0,037$ & 50,7 & 14 & 68 & 10 & 3 & 3 \\
\hline & Total calculado & 100,0 & 47 & 42 & 7 & 2 & 2 \\
\hline \multirow{3}{*}{ P17 } & $+0,037$ & 68,7 & 86 & 6 & 7 & 1 & 0,4 \\
\hline & $-0,037$ & 31,3 & 42 & 31 & 19 & 3 & 2 \\
\hline & Total calculado & 100,0 & 73 & 14 & 11 & 2 & 1 \\
\hline \multirow{3}{*}{ P18 } & $+0,037$ & 53,4 & 88 & 7 & 4 & 1 & 0,2 \\
\hline & $-0,037$ & 46,6 & 27 & 58 & 12 & 6 & 0,2 \\
\hline & Total calculado & 100,0 & 59 & 31 & 8 & 2 & 0,2 \\
\hline \multirow{3}{*}{ P20 } & $+0,037$ & 68,8 & 84 & 4 & 10 & 2 & 0,4 \\
\hline & $-0,037$ & 31,2 & 54 & 16 & 25 & 4 & 0,3 \\
\hline & Total calculado & 100,0 & 75 & 7 & 15 & 2 & 0,4 \\
\hline \multirow{3}{*}{ P26 } & $+0,037$ & 60,5 & 80 & 7 & 12 & 1 & 0,5 \\
\hline & $-0,037$ & 39,5 & 18 & 54 & 21 & 3 & 1 \\
\hline & Total calculado & 100,0 & 56 & 26 & 16 & 2 & 1 \\
\hline \multirow{3}{*}{ P29 } & $+0,037$ & 70,2 & 83 & 4 & 12 & 1 & 0,5 \\
\hline & $-0,037$ & 29,8 & 36 & 19 & 39 & 4 & 0,3 \\
\hline & Total calculado & 100,0 & 69 & 8 & 20 & 2 & 0,4 \\
\hline \multirow{3}{*}{ U06 } & $+0,037$ & 73,7 & 83 & 7 & 8 & 1 & 1 \\
\hline & $-0,037$ & 26,3 & 59 & 17 & 20 & 2 & 1 \\
\hline & Total calculado & 100,0 & 77 & 10 & 11 & 2 & 1 \\
\hline \multirow{3}{*}{ U13 } & $+0,037$ & 69,1 & 85 & 9 & 5 & 1 & 1 \\
\hline & $-0,037$ & 30,9 & 62 & 17 & 14 & 3 & 1 \\
\hline & Total calculado & 100,0 & 79 & 11 & 8 & 2 & 1 \\
\hline \multirow{3}{*}{ U21 } & $+0,037$ & 71,6 & 85 & 7 & 6 & 1 & 0,5 \\
\hline & $-0,037$ & 28,4 & 62 & 19 & 17 & 3 & 1 \\
\hline & Total calculado & 100,0 & 78 & 11 & 9 & 2 & 1 \\
\hline
\end{tabular}




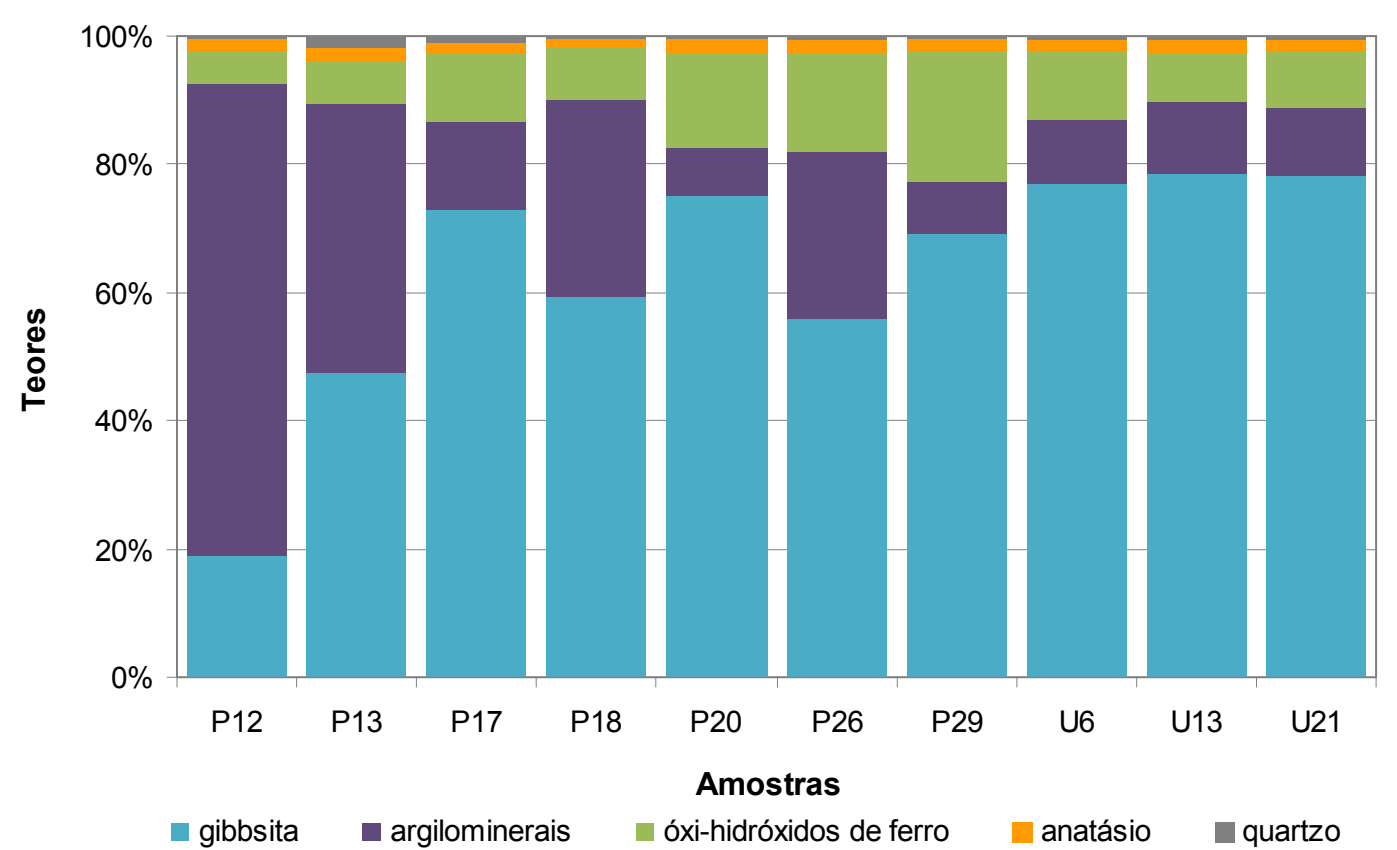

Figura 40 - Estimativa mineralógica apoiada em procedimentos de caracterização mineral

\subsubsection{Espectroscopia Mössbauer}

Os parâmetros de Mössbauer obtidos para as amostras estudadas, bem como a determinação das proporções de fases minerais portadoras de ferro nas mesmas, são apresentados na Tabela 8. Os ajustes dos espectros Mössbauer que permitiram tal quantificação são apresentados no Apêndice A.

Tabela 8 - Parâmetros de Mössbauer e proporções das fases portadoras de ferro

\begin{tabular}{|c|c|c|c|c|c|c|c|c|c|c|}
\hline \multirow[t]{2}{*}{ Amostra } & \multicolumn{2}{|c|}{$\begin{array}{c}\mathrm{Fe}^{3+} \\
\text { (Dubleto) }\end{array}$} & \multicolumn{2}{|c|}{$\begin{array}{l}\text { Goethita } \\
\text { (Sexteto I) }\end{array}$} & \multicolumn{2}{|c|}{$\begin{array}{l}\text { Hematita } \\
\text { (Sexteto II) }\end{array}$} & \multirow{2}{*}{$\begin{array}{c}\% \mathrm{Fe}_{2} \mathrm{O}_{3} \\
\text { MRN }\end{array}$} & \multicolumn{3}{|c|}{$\%$ Fases portadoras de Fe } \\
\hline & $\varepsilon(\mathrm{mm} / \mathrm{s})$ & Área(\%) & $B_{h f}(T)$ & Área(\%) & $B_{h f}(T)$ & Área(\%) & & $\mathrm{Fe}^{3+}$ & goethita & hematita \\
\hline $\mathrm{P} 12$ & 0,5 & 37 & 35,8 & 34 & 51,0 & 29 & 5,04 & 1 & 2 & 2 \\
\hline P13 & 0,5 & 37 & 36,1 & 23 & 51,0 & 40 & 6,51 & 1 & 1 & 3 \\
\hline P17 & 0,6 & 18 & 35,1 & 45 & 51,0 & 37 & 10,6 & 1 & 5 & 5 \\
\hline P18 & 0,5 & 25 & 35,5 & 27 & 51,0 & 49 & 7,85 & 1 & 2 & 4 \\
\hline P20 & 0,6 & 16 & 28,9 & 12 & 51,0 & 72 & 14,8 & 1 & 2 & 12 \\
\hline P26 & 0,5 & 20 & 36,0 & 28 & 51,0 & 52 & 17,9 & 2 & 5 & 1 \\
\hline P29 & 0,5 & 13 & - & - & 50,9 & 87 & 20,5 & 1 & - & 19 \\
\hline U06 & 0,5 & 20 & 28,9 & 20 & 51,0 & 60 & 10,8 & 1 & 2 & 7 \\
\hline U13 & 0,5 & 24 & 33,2 & 18 & 51,0 & 56 & 8,82 & 1 & 1 & 6 \\
\hline U21 & 0,5 & 22 & 35,8 & 22 & 51,0 & 56 & 8,55 & 1 & 2 & 5 \\
\hline
\end{tabular}

De maneira geral, as fases portadoras de ferro correspondem entre 5 e $20 \%$ em massa das amostras estudadas, conforme ilustrado na Figura 41. 


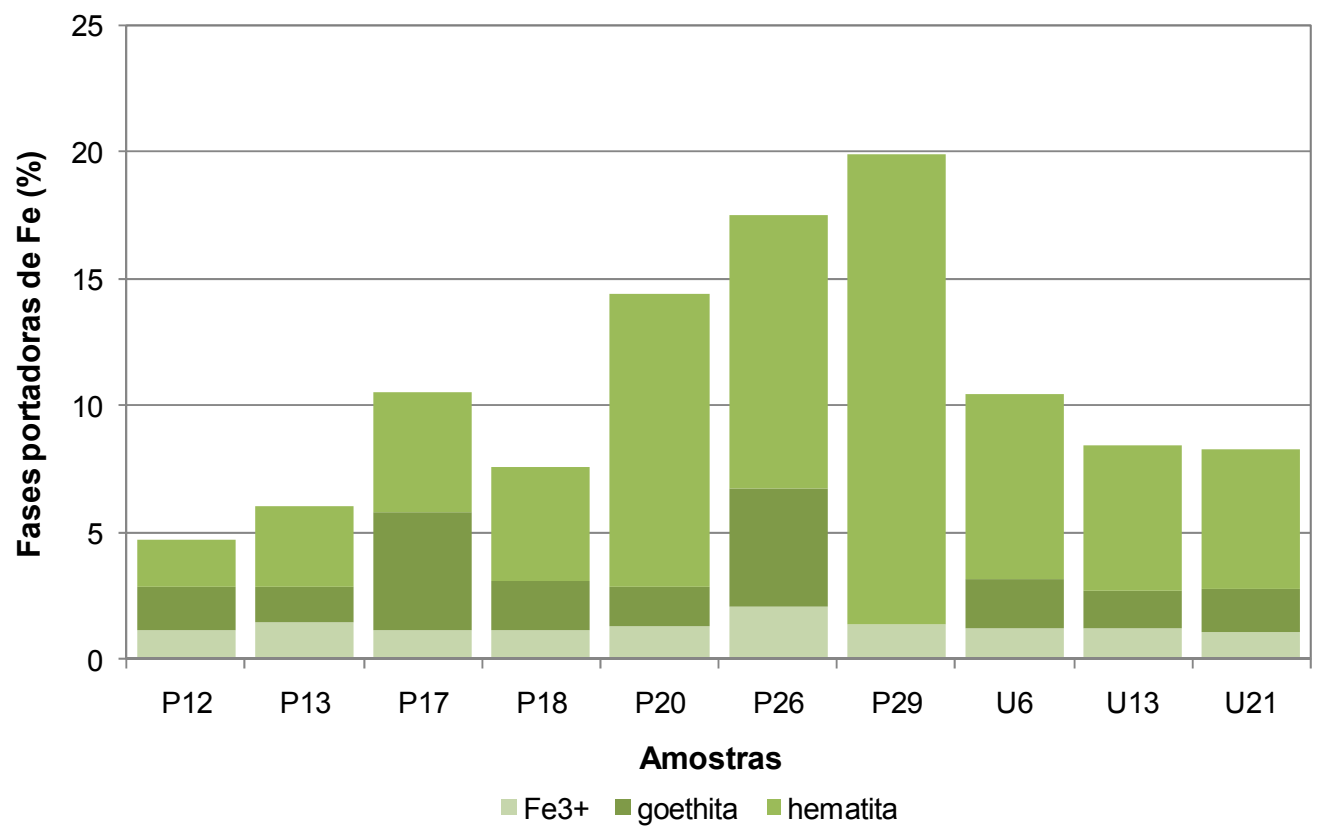

Figura 41 - Estimativa das fases portadoras de ferro por Mössbauer (\% em massa)

Os espectros Mössbauer da maioria das amostras são similares e apresentam basicamente as mesmas características: um dubleto e dois sextetos.

O dubleto é atribuído a uma fase de $\mathrm{Fe}^{3+}$, que pode relacionar-se a uma forma paramagnética, de cristalinidade comprometida, podendo ser referente a uma goethita de baixíssima cristalinidade, ou mesmo a variedade limonita (?), com dimensões muito pequenas de tamanhos de partículas e possíveis substituições isomórficas.

A partir dos resultados de área relativa calculou-se a partição do Fe entre as fases minerais, sendo que a fase de $\mathrm{Fe}^{3+}$ é responsável por valores entre 10 e $33 \%$ do total de ferro contido nas amostras e, baseando-se nos teores de $\mathrm{Fe}_{2} \mathrm{O}_{3}$ dosados pela MRN, equivale a proporções entre 1 a $2 \%$ das amostras estudadas.

O primeiro dos sextetos refere-se à goethita, com campo magnético hiperfino $\left(B_{h f}\right)$ em torno de 28,9 - 36,1 ( $T$ ) nas amostras. Este valor é inferior ao ideal teórico da goethita, indicando o pequeno tamanho de cristais e possibilidade de substituições elementares. Na amostra P29 não foi observada tal fase mineral.

A goethita é responsável por valores entre 9 e 39\% em massa do ferro total contido nas amostras e, baseando-se nos teores de $\mathrm{Fe}_{2} \mathrm{O}_{3}$ dosados pela MRN, equivale a conteúdos entre 1 a $5 \%$ das amostras. 
Por fim, o segundo sexteto refere-se à hematita, com campo magnético hiperfino $\left(B_{\mathrm{hf}}\right)$ variando entre 50,9 e 51,0 (T). Estes valores também são inferiores ao teórico da hematita e sugerem o pequeno tamanho de cristais ou mesmo a possibilidade de substituições isomórficas. A hematita é responsável por valores entre 36 e $90 \%$ do ferro total contido nas amostras e, baseando-se nos teores de Fe2O3 dosados pela MRN, equivale a proporções entre 1 e 19\% das amostras.

\subsubsection{Difração de raios $X$ com método de Rietveld}

As variações dos conteúdos mineralógicos presentes nas amostras exigiram a definição de distintas estratégias de refinamento pelo método de Rietveld.

\subsubsection{Estratégias de refinamento}

A Tabela 9 detalha a seqüência de parâmetros aplicados em cada uma das estratégias definidas.

A estratégia I foi desenvolvida para as amostras com alta concentração de gibbsita (teores superiores a $84 \%$, quantificados por DRX-Rietveld), especificamente aquelas relativas à usina de beneficiamento e a parte dos materiais inseridos ao denominado Grupo PIV da pesquisa mineral, como a amostra P17. Nesta estratégia, os parâmetros de cela unitária, orientação preferencial e W de perfil de pico para a gibbsita referem-se às principais etapas do refinamento, sendo que os fatores $\mathrm{V}$ e $\mathrm{U}$ de perfil de pico são também aplicados a gibbsita e exclusivamente para este tipo de material.

A denominada estratégia II é bastante semelhante a I, sendo que os parâmetros de cela unitária para os menores constituintes são, nesta, mais interferentes no refinamento e, portanto, foram aplicados a apenas algumas dessas fases. Essa estratégia foi adequada a amostras com conteúdo de gibbsita discretamente inferior ao das amostras refinadas pela estratégia I, porém com proporções mais elevadas de óxi-hidróxidos de ferro, característica das amostras inseridas no Grupo PIII dentre os materiais da pesquisa mineral. 


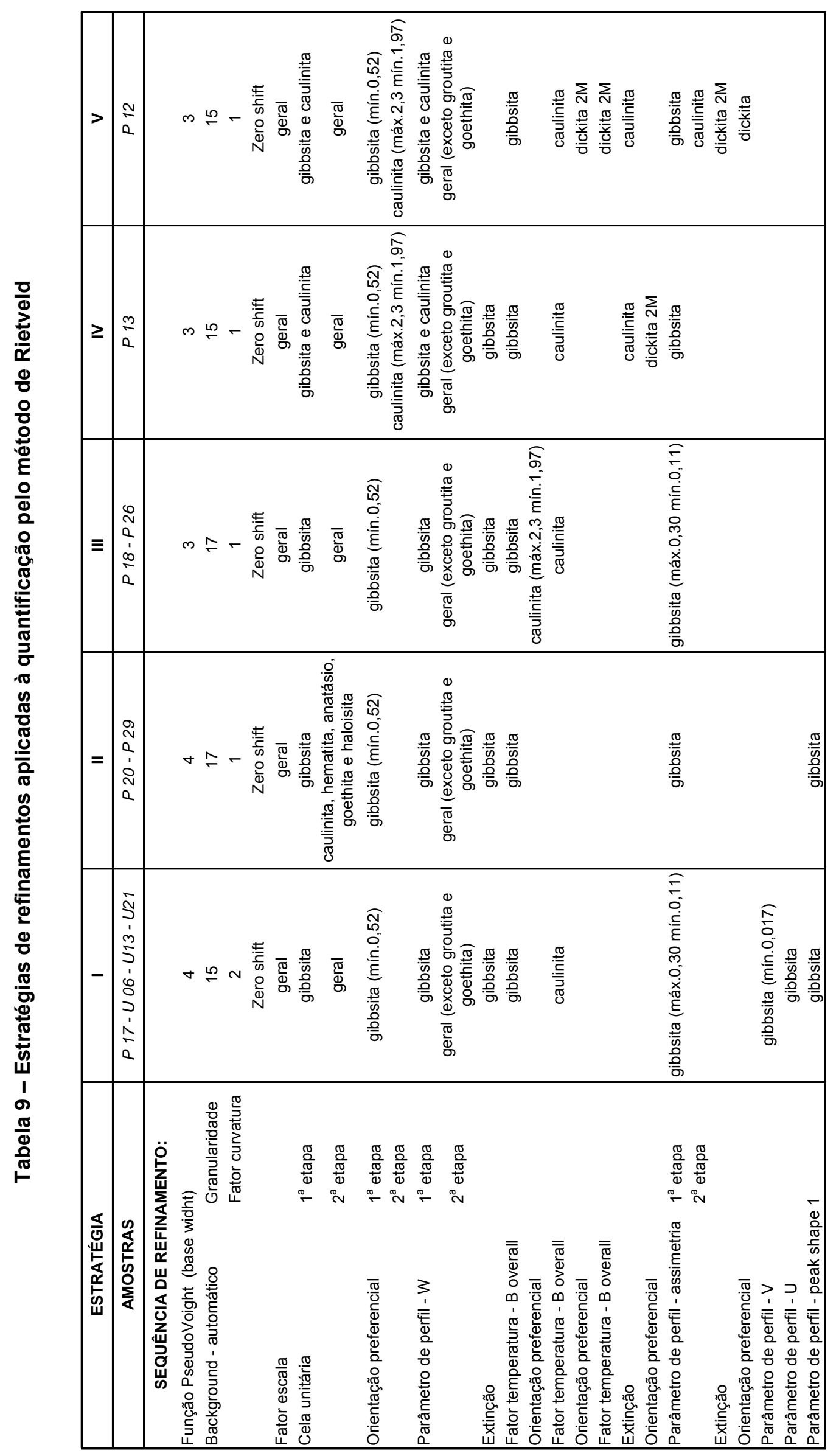


A estratégia III foi desenvolvida para as amostras com proporção de gibbsita em torno de 58 e $66 \%$, sendo que, além do refinamento dos principais parâmetros para a gibbsita, o conteúdo de argilomineral (27-30\%) exige que a orientação preferencial da caulinita seja considerada. Os materiais aplicáveis a essa estratégia referem-se aos semelhantes do agrupamento PIV da pesquisa mineral. Atenta-se mais uma vez para o fato da amostra P17, incluída neste Grupo PIV da análise por agrupamento, ter sido refinada pela estratégia I e não pela III; essa amostra apresenta um conteúdo mais elevado de gibbsita dentre suas similares da pesquisa mineral, tendo exigido etapas de refinamento semelhantes aos produtos do beneficiamento.

As estratégias IV e V foram aplicadas às amostras com maiores proporções de argilominerais (teores superiores a 45\% calculados por DRX-Rietveld), sendo que parâmetros de cela unitária e orientação preferencial da caulinita são fundamentais e considerados nas primeiras etapas de refinamento. Essas estratégias se diferenciam principalmente em relação ao número de estruturas cristalinas de argilominerais necessárias ao refinamento (caulinita, dickita, dickita $2 \mathrm{M}$ ), sendo que a estratégia IV aplica-se a amostras similares àquelas do Grupo PI da pesquisa mineral, enquanto a V aplica-se àquelas semelhantes aos componentes do Grupo PII.

De maneira geral, destaca-se a relevância de se trabalhar com os parâmetros de background dos difratogramas e a imprecisão nos resultados no refinamento para minerais em proporções muito pequenas, já próximas ao limite de detecção da técnica de DRX-Rietveld. Verificou-se, nesse trabalho, certa imprecisão para a quantificação de fases em porcentagens inferiores a $5 \%$ nas amostras.

Complementarmente, a Figura 42 apresenta o dendograma da análise por agrupamento realizada isoladamente para os difratogramas das dez amostras selecionadas como representativas do total, ilustrando a semelhança das amostras refinadas pela mesma estratégia, além de correlacionar a estratégia a ser aplicada a cada conjunto de amostras com características semelhantes, definido pela análise por agrupamento.

O fato de parte das amostras do agrupamento PIV da pesquisa mineral ter sido refinada pela estratégia I e parte pela estratégia III, evidenciam significativas dissimilaridades de amostras dentro do mesmo. 


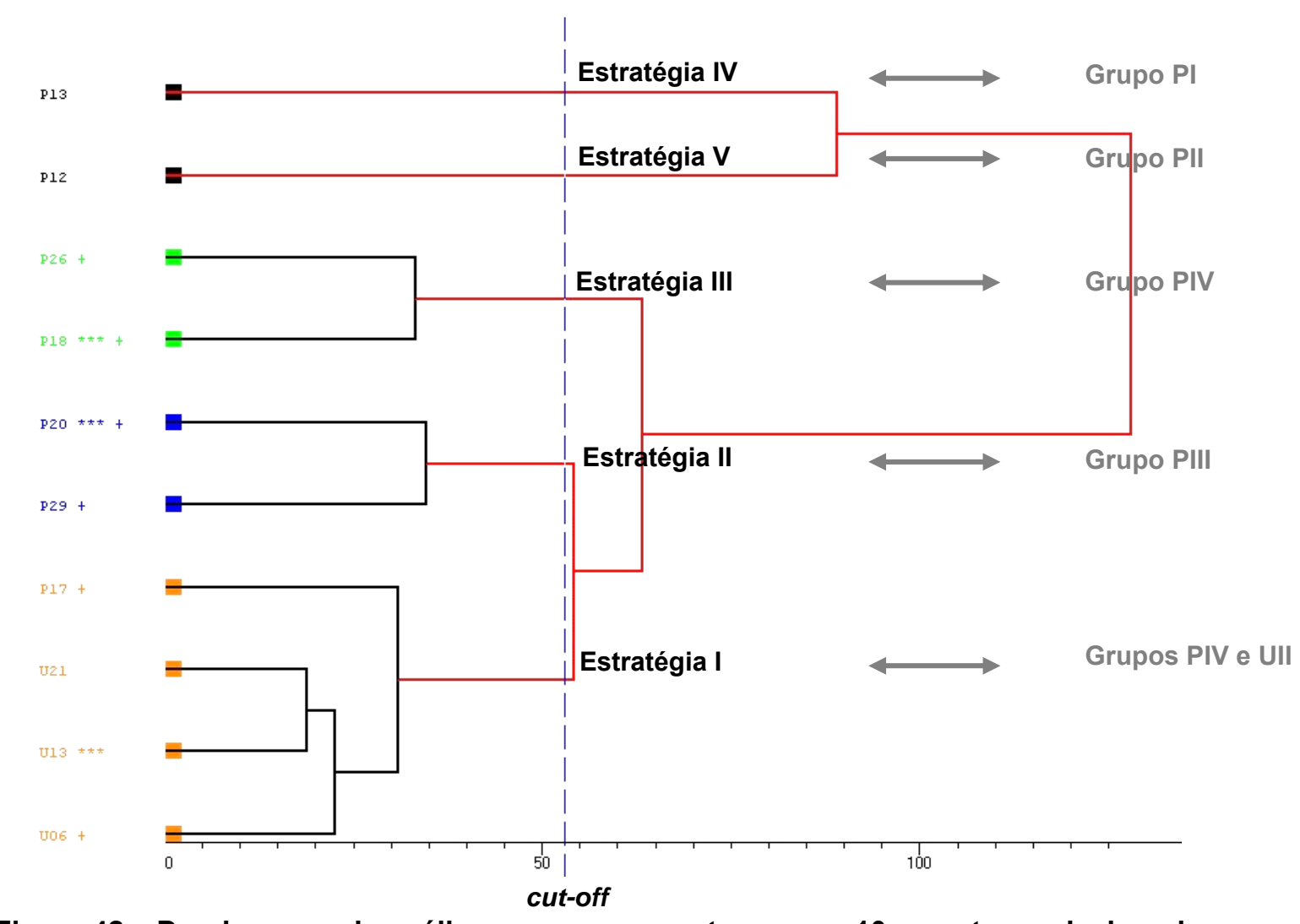

Figura 42 - Dendograma da análise por agrupamento para as 10 amostras selecionadas, identificando a estratégia a ser aplicada a cada tipo de amostra de bauxita (cut-off de 53)

Ademais, o valor do cut-off utilizado para esse último dendograma mostrou-se adequado para que as estratégias desenvolvidas fossem satisfatoriamente aplicadas a todo o universo de amostras estudadas. Em função disso, o mesmo foi aplicado às análises por agrupamento efetuadas anteriormente para o conjunto de amostras $\mathrm{P} e$ $\mathrm{U}$, visando confirmar as diferenças identificadas dentro de cada grupo. Assim, a Figura 43 e a Figura 44 apresentam, respectivamente, a reorganização dos agrupamentos para as amostras $\mathrm{P}$ e $\mathrm{U}$, segundo o cut-off de 53.

No caso das amostras da pesquisa mineral $(P)$, o novo cut-off agrupou as amostras em 6 classes e confirmou as dissimilaridades existentes dentro do Grupo PIV, subdividindo-o em 3. A amostra P17, refinada pela estratégia I, realmente foi posta separadamente daquelas refinadas pela estratégia III. Foi também observada a existência de um subgrupo que não foi amostrado para a quantificação por DRXRietveld, composto por apenas 2 amostras (P09 e P16), sendo desconhecida a necessidade ou não de se definir uma estratégia de refinamento específica a tal grupo. 


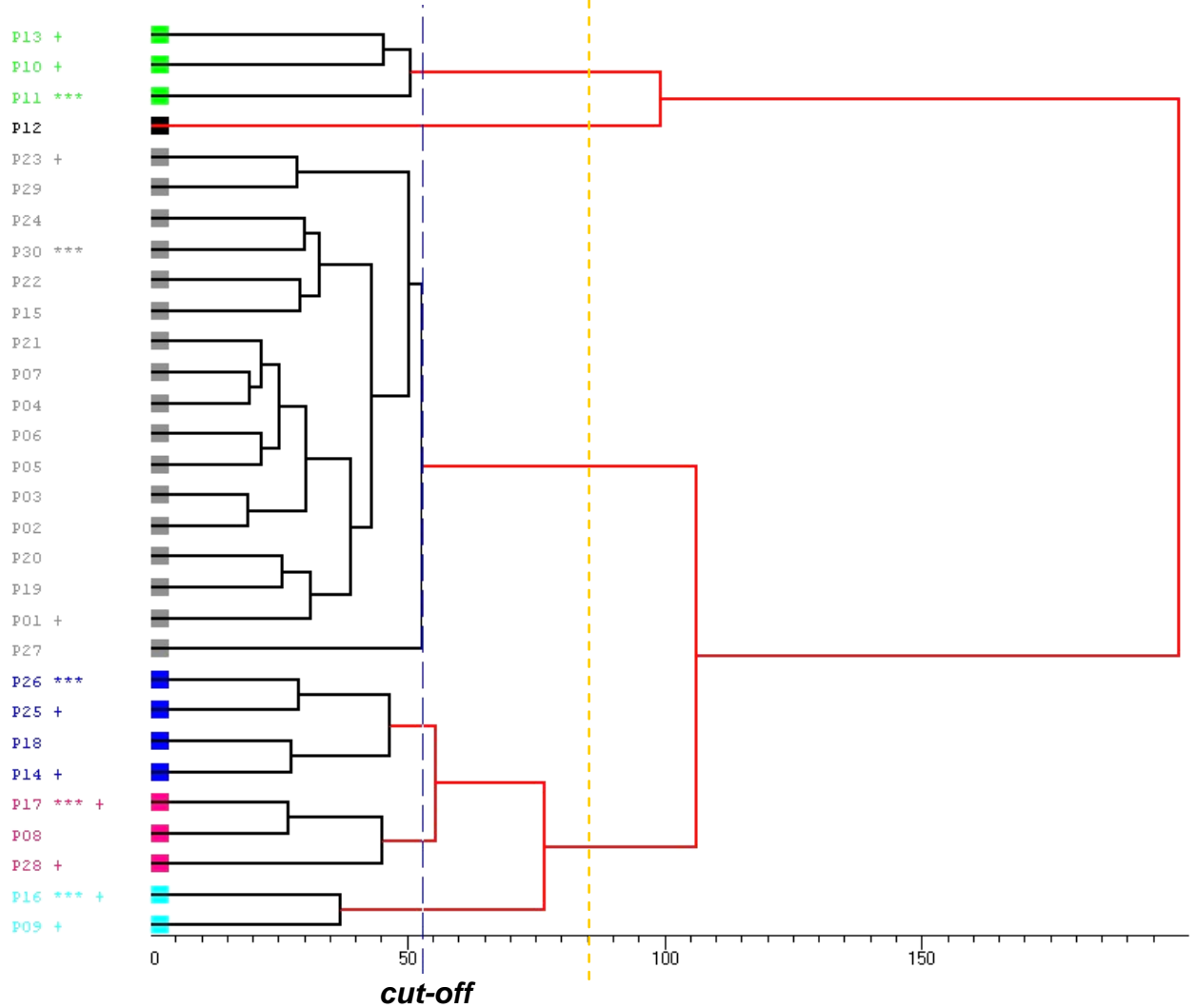

Figura 43 - Dendograma da análise por agrupamento das amostras da pesquisa mineral (P), segundo um cut-off de 53. Em amarelo, cut-off aplicado inicialmente.
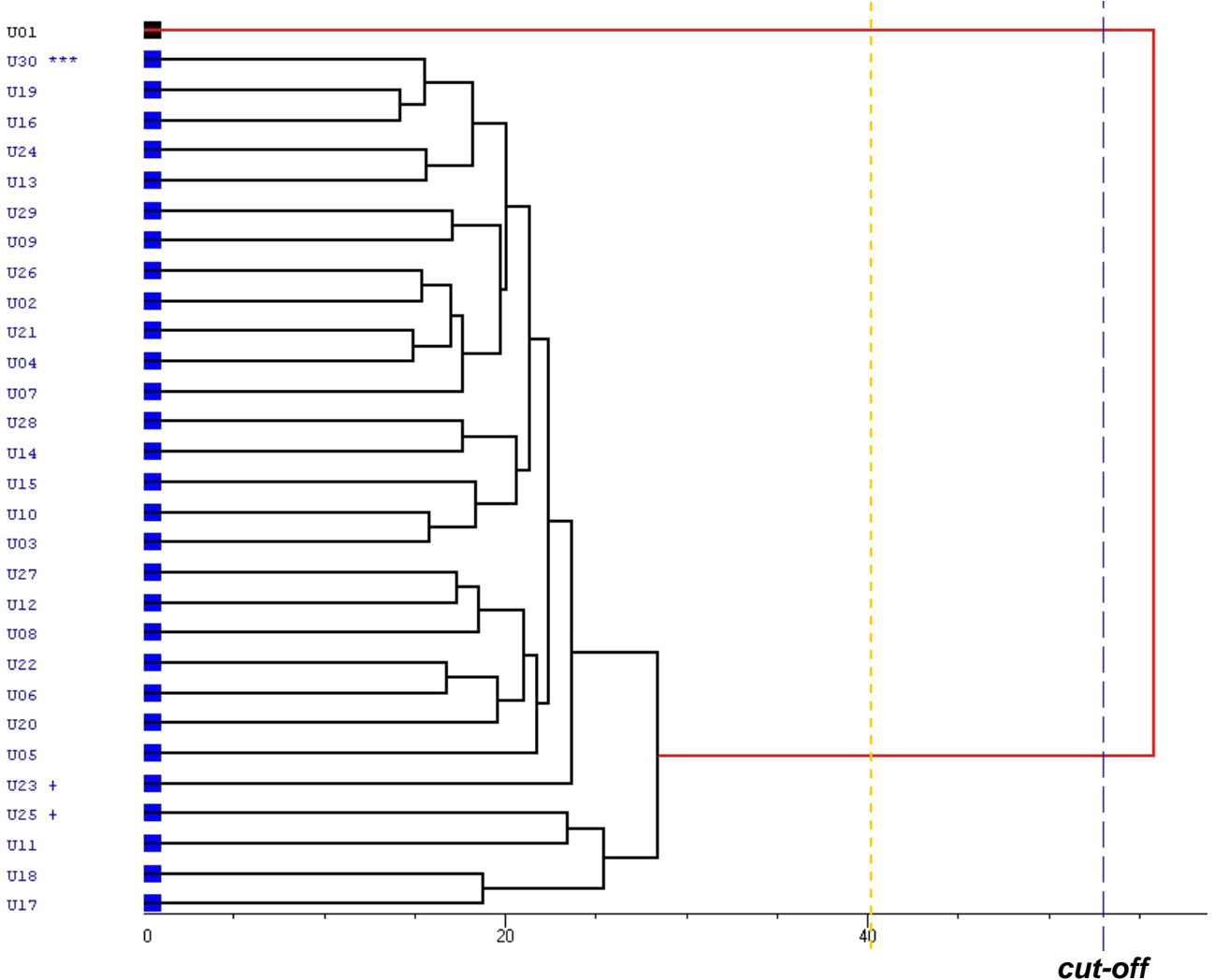

Figura 44 - Dendograma da análise por agrupamento dos produtos de beneficiamento (U), segundo um cut-off de 53. Em amarelo, cut-off aplicado inicialmente. 
Com relação aos produtos de beneficiamento, a alteração do valor de cut-off não alterou o comportamento dos agrupamentos inicialmente definidos.

O diagrama de análise do componente principal (PCA), relativo aos três primeiros valores de Eigenvalues plotados em gráfico 3D para as dez amostras selecionadas como representativas, é apresentado na Figura 45.

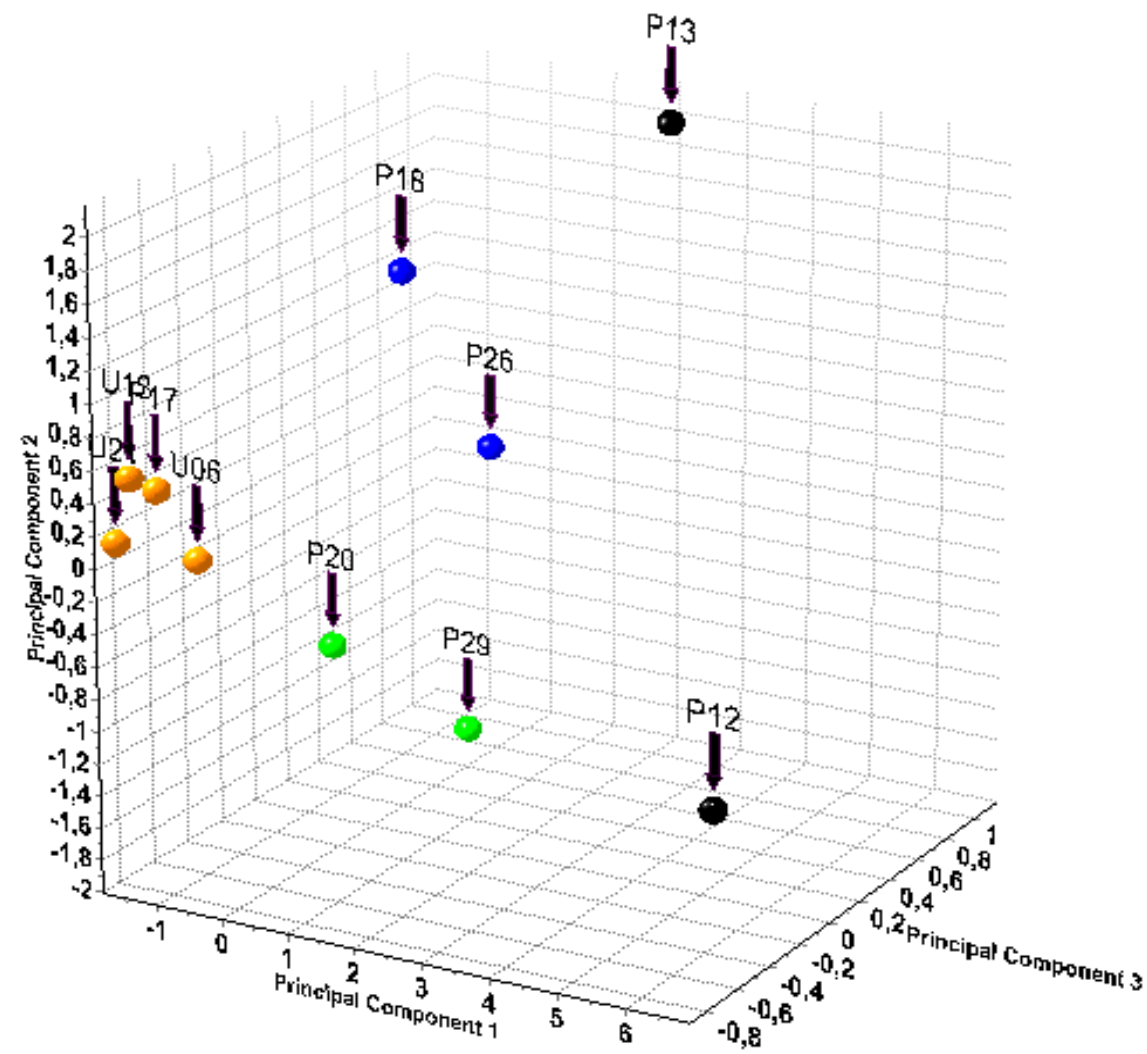

Figura 45 - Diagrama de análise do componente principal (três primeiros Eigenvalues) das 10 amostras selecionadas para análise por DRX-Rietveld, agrupadas em função da estratégia de refinamento a que foram submetidas

\subsubsection{Quantificações por DRX-Rietveld}

As proporções das fases minerais das amostras, obtidas por difratometria de raios X com o método de Rietveld são apresentadas na Tabela 10.

As amostras U06, U13, U21 e P17, refinadas pela Estratégia I, são compostas predominantemente por gibbsita, com teores entre 84 e $87 \%$, além de $6-9 \%$ de caulinita, $3-5 \%$ de hematita e teores menores para as demais fases $(<2 \%)$. Essas quantificações alcançaram valores entre 5,93 e 7,51 para o indicador estatístico GOF e entre 10,7 e 12,0 para o $R_{w p}$. 


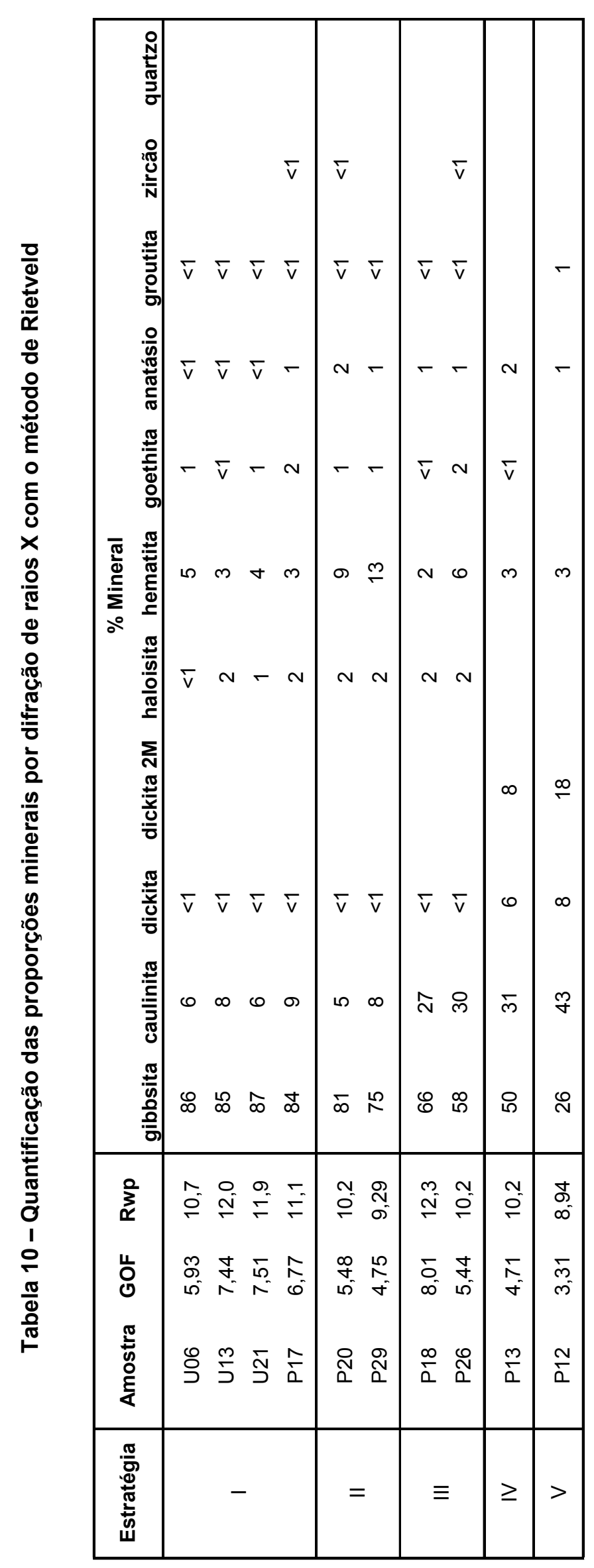


As amostras P20 e P29 foram submetidas à Estratégia II de refinamento e apresentam conteúdos elevados de gibbsita (75 a 81\%), com proporções de hematita de 9 a 13\%, caulinita entre 5 e $8 \%$ e quantidades menores para os demais constituintes $(<2 \%)$. Esses refinamentos alcançaram valores de GOF em torno de 4,75 e 5,48 e $R_{w p}$ entre 9,29 e 10,2 .

As denominadas P18 e P26 foram submetidas à Estratégia III de refinamento e referem-se a amostras com conteúdos de gibbsita entre 58 e $66 \%$ e elevado teor de caulinita, entre 27 e 30\%; o conteúdo de hematita está entre 2 e 6\%, enquanto que as demais fases não ultrapassam $2 \%$. Esses refinamentos alcançaram valores entre 5,44 e 8,01 para o indicador estatístico GOF e entre 10,2 e 12,3 para o $R_{w p}$.

A P13 foi refinada pela Estratégia IV e é constituída por $50 \%$ de gibbsita, $45 \%$ de argilominerais (31\% de caulinita, $6 \%$ de dickita e $8 \%$ de dickita $2 \mathrm{M}$ ), além de $3 \%$ de hematita e teores menores para os demais componentes $(<2 \%)$. Nesse refinamento foi obtido valor de GOF igual a 4,71 e $R_{w p}$ igual a 10,2.

Por fim, a amostra P12, refinada pela Estratégia $V$ e baseada em valores de 3,31 para o GOF e 8,94 para o $R_{w p}$, é constituída por $70 \%$ de argilominerais $(43 \%$ de caulinita, $8 \%$ de dickita e $18 \%$ de dickita $2 \mathrm{M}$ ), além de $26 \%$ de gibbsita, $3 \%$ de hematita e inferiores a $1 \%$ para os demais componentes.

Observa-se que a haloisita não foi identificada nas amostras P12 e P13, em que outros argilominerais estão significativamente presentes.

A groutita e o zircão mostraram-se sempre como minerais traços nas amostras, enquanto que o quartzo, apesar de ser ter sido identificado nos difratogramas e pela microscopia eletrônica de varredura, mostrou-se sem significado numérico através dos refinamentos aplicados. Esses minerais ocorrem em proporções próximas ao limite de detecção do método DRX-Rietveld.

Na Figura 46 é apresentado o difratograma refinado para a amostra U06, sendo que os demais refinamentos realizados estão expostos no Apêndice B.

A Figura 47 ilustra os resultados quantitativos obtidos para as amostras, por DRX-Rietveld, considerando as principais fases quantificadas (>2\%). 

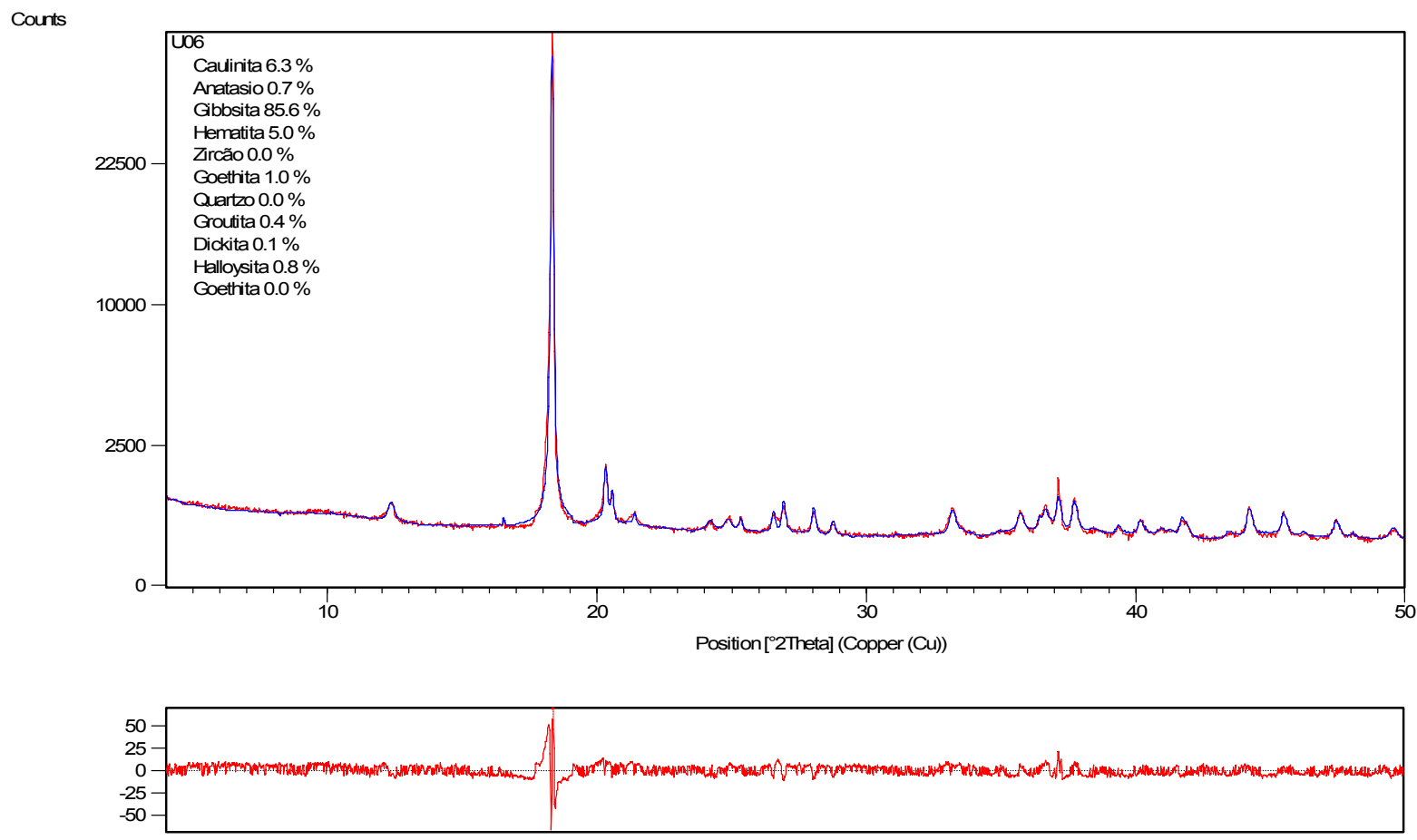

Figura 46 - Difratograma da amostra U06 refinado pelo método de Rietveld

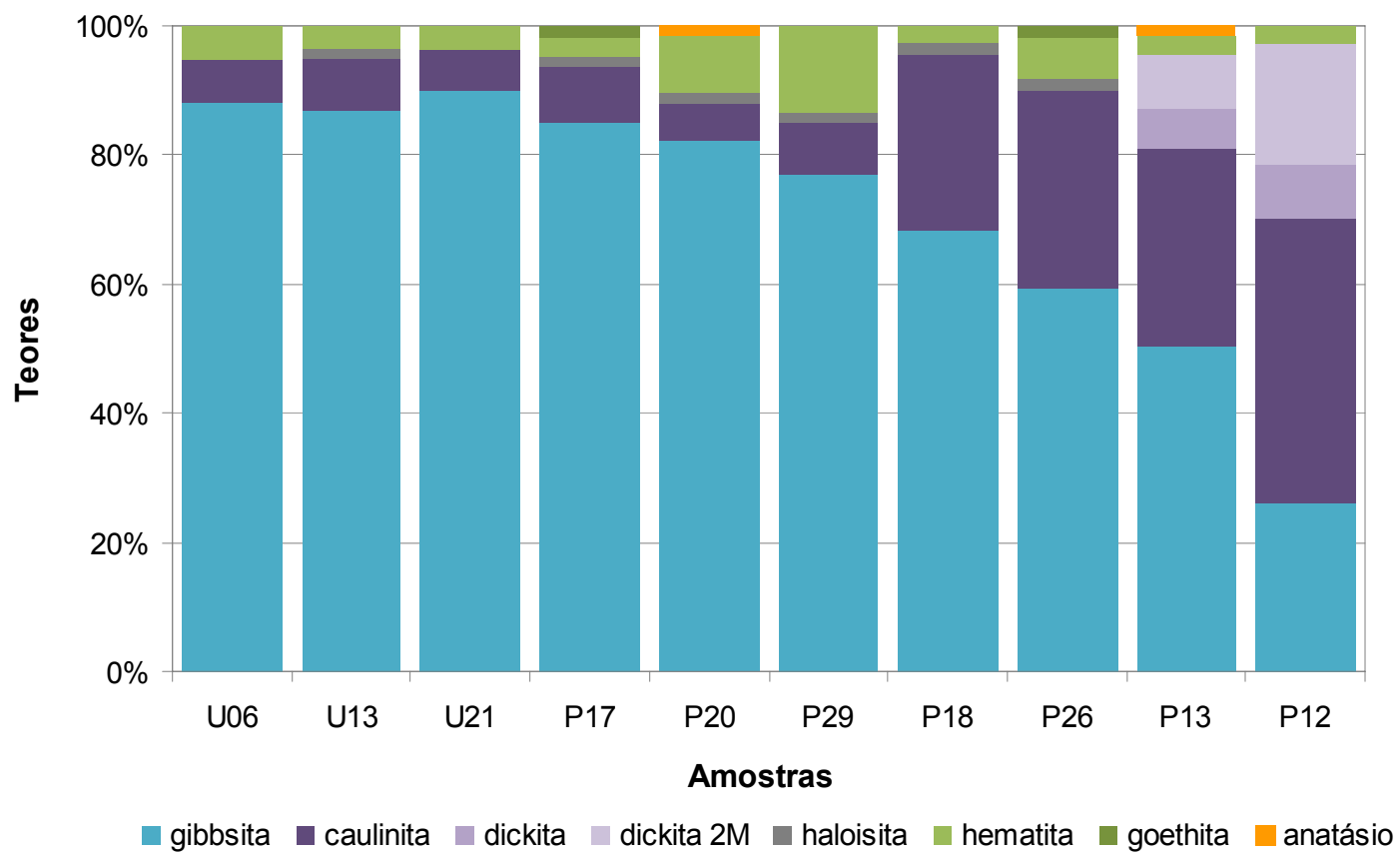

Figura 47 - Quantificação mineralógica obtida por DRX-Rietveld para as principais fases (>2\%) 


\section{DISCUSSÃO DE RESULTADOS}

Como parte do objetivo deste trabalho, nesse item é apresentada a correlação dos valores das proporções minerais obtidas para os maiores constituintes das amostras (gibbsita, argilominerais e óxi-hidróxidos de ferro), através de métodos de caracterização mineralógica baseada em separações minerais, por espectroscopia Mössbauer e por difração de raios $\mathrm{X}$ com o método de Rietveld.

Dados de análises químicas específicas $\left(\mathrm{Al}_{2} \mathrm{O}_{3}\right.$ aproveitável e $\mathrm{SiO}_{2}$ reativa), usualmente aplicadas na avaliação do minério de bauxita, são também correlacionados àqueles gerados por difração de raios $\mathrm{X}$ com o método de Rietveld, visando a aferir esta última ferramenta frente ao estudo de bauxitas.

\subsection{Comparação entre os métodos de quantificação mineral}

Conforme a Figura 48 e a Figura 49, observa-se significativa similaridade especificamente entre as proporções de gibbsita e da soma de argilominerais estimadas através dos métodos tradicionais de caracterização e por DRX-Rietveld, sendo obtidos altos valores de correlação linear $\left(R^{2}\right)$, superiores a 0,976 . Entretanto, os resultados determinados por DRX-Rietveld mostram uma ligeira e sistemática superestimação desses minerais em relação à outra metodologia, sendo algo mais acentuado para a gibbsita.

A maior dissimilaridade observada entre os três métodos de quantificação aplicados referem-se às fases portadoras de ferro, essencialmente hematita, com menores proporções de goethita e, segundo as análises por espectroscopia Mössbauer, quantidades de $\mathrm{Fe}^{3+}$ de baixa cristalinidade e/ou amorfo.

Entre os resultados de caracterização mineral apoiado em separações minerais e Mössbauer, considerando-se as porcentagens totais de óxidos + hidróxidos de ferro, foi obtido um razoável valor de correlação linear, de 0,971, porém, considerando-se os resultados obtidos por DRX-Rietveld as variações são maiores. Observa-se $R^{2}$ igual a 0,865 e 0,832 quando correlacionados os resultados de DRX-Rietveld com os valores da caracterização tradicional e Mössbauer, respectivamente. 

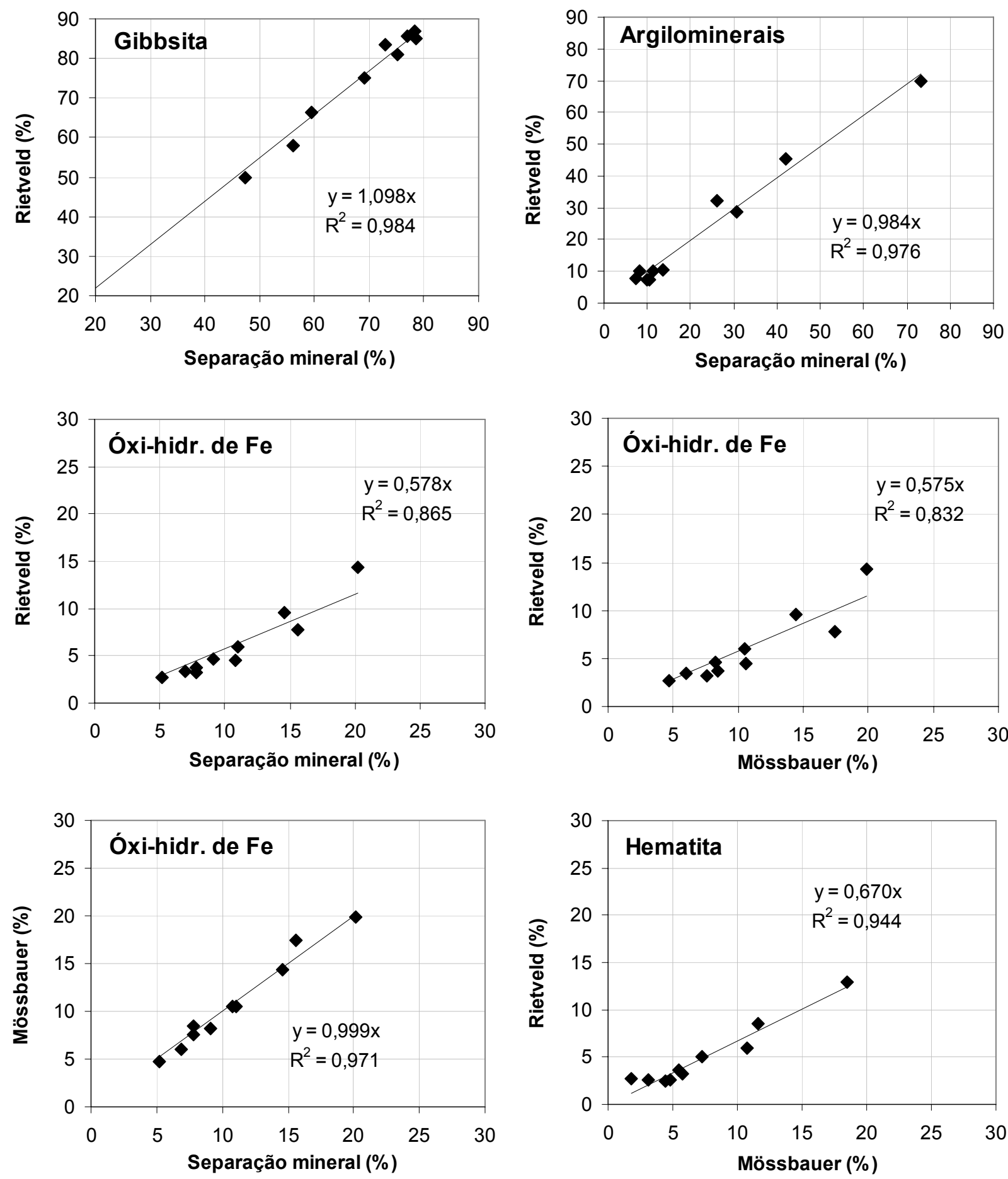

Figura 48 - Diagramas de correlação entre as proporções de gibbsita, argilominerais e óxidos e hidróxidos de ferro obtidas pelas diferentes técnicas de quantificação mineral aplicadas

Destaca-se, porém, o fato de que as quantificações obtidas por Mössbauer tiveram como base os teores de $\mathrm{Fe}_{2} \mathrm{O}_{3}$ total dosados pela MRN e isso, obviamente, favorece a correlação entre essa técnica e os resultados gerados pela caracterização mineral apoiada em separações minerais e análises químicas. 

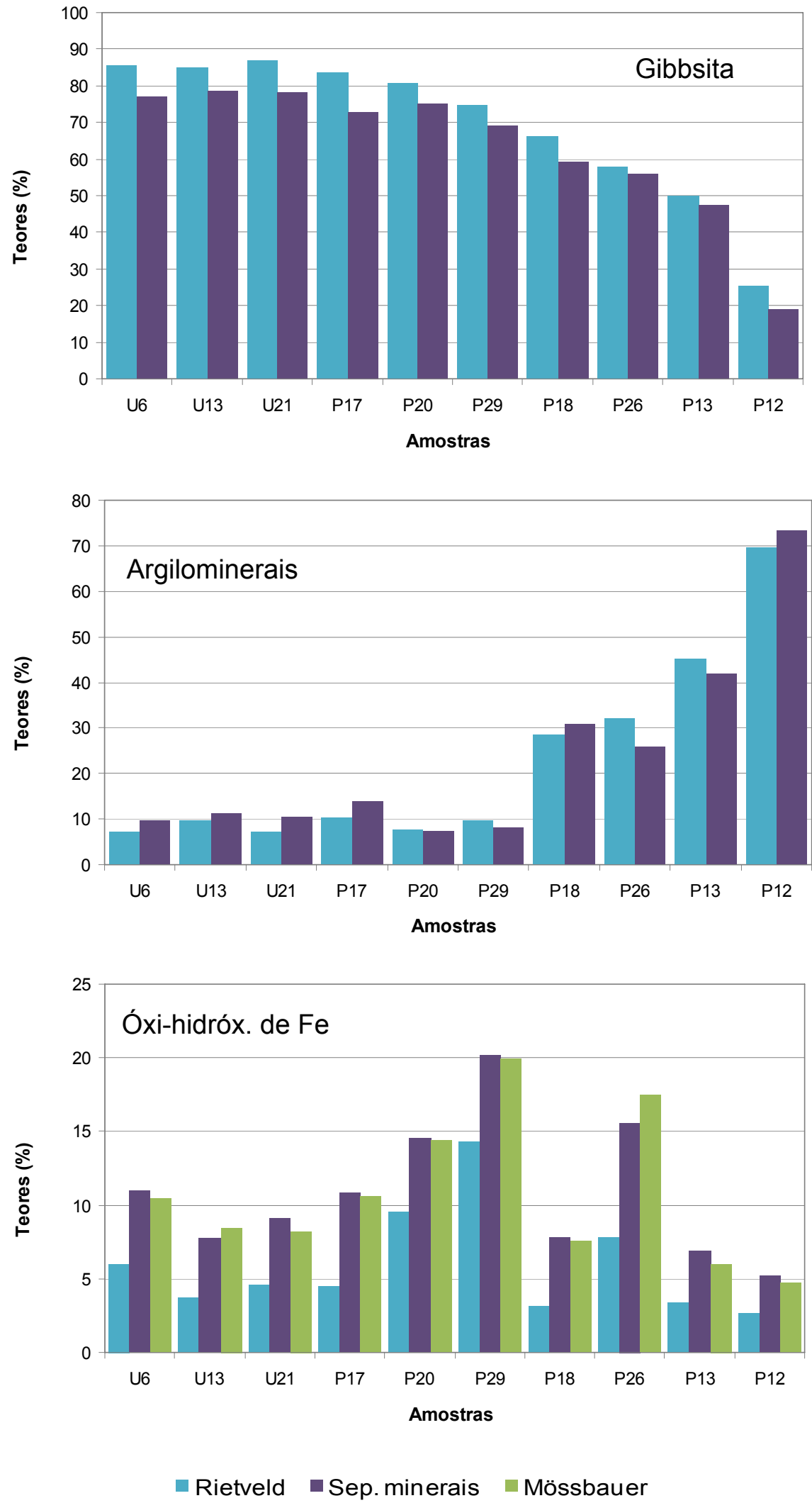

Figura 49 - Comparação entre as proporções de gibbsita, argilominerais e óxi-hidróxidos de ferro obtidas pelas diferentes técnicas de quantificação mineral aplicadas 
As proporções de minerais de ferro obtidas por DRX-Rietveld são sistematicamente inferiores às dosadas pelas demais metodologias. Quando são analisados os conteúdos da hematita especificamente, que foram possíveis de serem quantificados diretamente tanto por DRX-Rietveld como por Mössbauer, a correlação linear é elevada a 0,944, sugerindo que a hematita, dentre as fases portadoras de ferro, é a que melhor responde ao método quantitativo por difração de raios $X$, porém sem a relação $1: 1$ quando comparada às demais técnicas quantitativas.

A goethita e a fase de $\mathrm{Fe}^{3+}$ de cristalinidade comprometida identificada por Mössbauer (goethita de baixíssima cristalinidade ou limonita), que podem responder por mais de $50 \%$ do ferro presente, praticamente não foram detectadas por DRX e, portanto, não foram consideradas na quantificação pelo método de Rietveld.

A subestimada quantificação dos óxidos e hidróxidos de ferro pode responder pelos ligeiros incrementos das proporções de gibbsita observadas na quantificação por DRX-Rietveld em relação à caracterização tradicional, visto que a primeira análise é normatizada em $100 \%$ para as fases presentes.

\subsection{Comparação entre DRX-Rieveld e análises químicas}

Elevada correlação linear $\left(R^{2}=0,967\right)$ foi observada diretamente entre as porcentagens de gibbsita obtidas por DRX-Rietveld e os teores de $\mathrm{Al}_{2} \mathrm{O}_{3}$ aproveitável fornecidos pela MRN, igualmente para os conteúdos de argilominerais e os teores de $\mathrm{SiO}_{2}$ reativa, conforme a Figura 50. Os teores de $\mathrm{Al}_{2} \mathrm{O}_{3}$ não aproveitável também apresentaram correlação com os valores de argilominerais, porém com maior dispersão de pontos, provavelmente devido a desvios analíticos.

Com relação às proporções de óxi-hidróxidos de ferro comparados aos teores de $\mathrm{Fe}_{2} \mathrm{O}_{3}$ total dosado pela $\mathrm{MRN}$, a correção linear é reduzida a 0,837 , sendo que o método de Rietveld subestima esse conteúdo em função da baixa cristalinidade / tamanho de cristais de parte dos minerais portadores de ferro, como também observado por microscopia eletrônica de varredura (MEV-EDS) e através de espectroscopia Mössbauer.

De acordo com as linhas de tendência definidas nos gráficos de correlação, são estimados desvios relativos sistemáticos da ordem de $10 \%$ superiores para os 
valores de gibbsita obtidos por DRX-Rietveld em relação àqueles calculados a partir de teores de $\mathrm{Al}_{2} \mathrm{O}_{3}$ aproveitável. Para os argilominerais esse desvio equivale a cerca de $9 \%$ superiores com relação àqueles obtidos a partir de teores de $\mathrm{SiO}_{2}$ reativa.
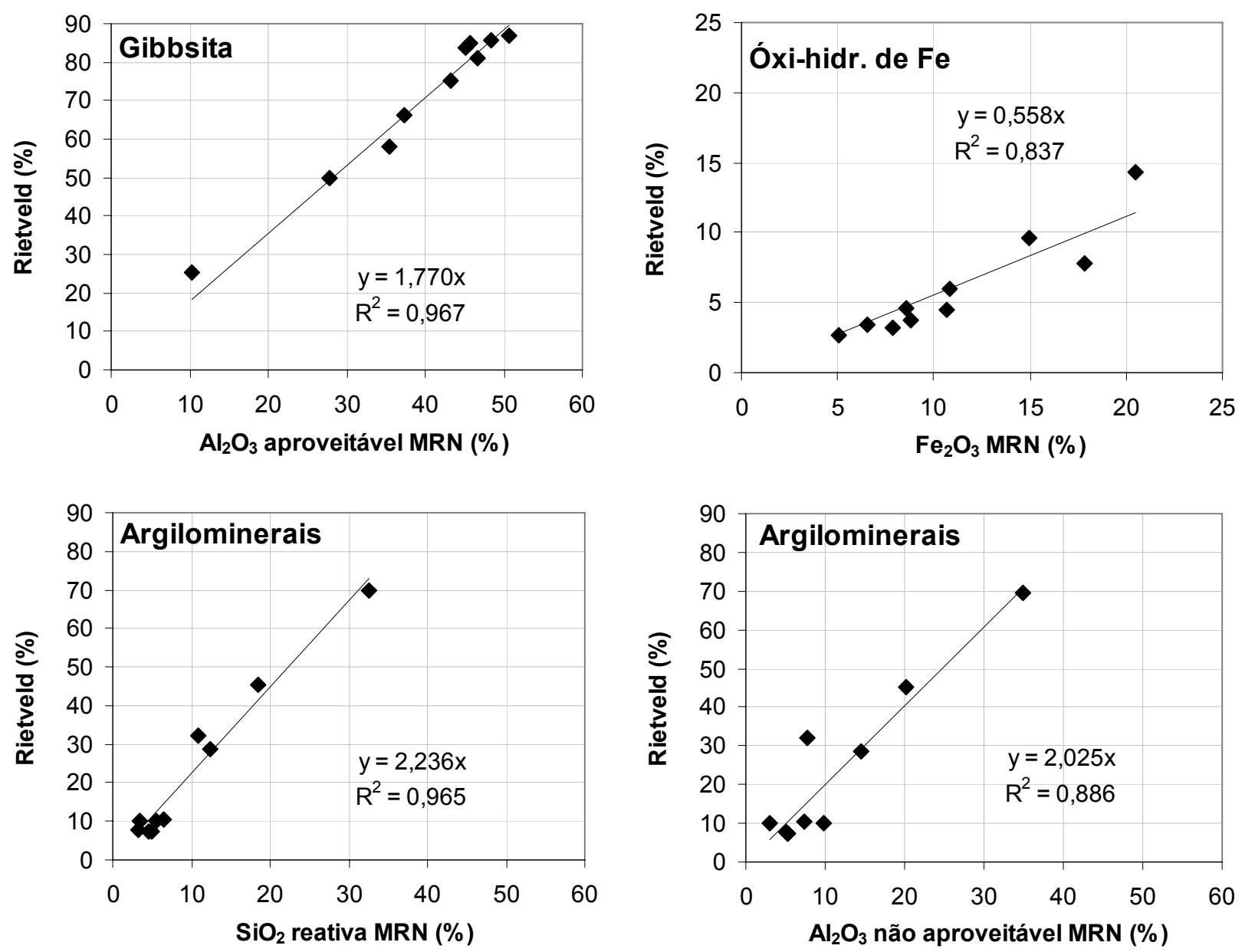

Figura 50 - Diagramas de correlação entre resultados quantitativos obtidos por DRX com o método de Rietveld com as análises químicas específicas de controle do minério de bauxita (MRN), considerando-se os maiores constituintes das amostras

No caso dos óxi-hidróxidos de ferro, as proporções obtidas por DRX-Rietveld são cerca da metade dos valores de análises químicas (teor Rietveld / 0,558).

Os elevados fatores de correlação obtidos entre a DRX-Rietveld e as análises químicas fornecidas pela MRN possibilitam a aplicação da primeira na determinação direta dos teores de $\mathrm{Al}_{2} \mathrm{O}_{3}$ aproveitável e $\mathrm{SiO}_{2}$ reativa apoiada nas curvas de correlação. No caso dos óxi-hidróxidos de $\mathrm{Fe}$, uma correlação aparentemente de $2^{\circ}$ grau pode ser estabelecida sendo, entretanto, necessária a agregação de um maior número de amostras para aumentar a confiabilidade desses dados. 


\section{CONCLUSÕES}

As bauxitas analisadas, correspondentes a materiais da pesquisa mineral e a produtos concentrados da usina de beneficiamento, são compostas preferencialmente por gibbsita, além de menores quantidades de argilominerais (essencialmente caulinita e, mais raramente, dickita e haloisita), hematita, anatásio, goethita e quartzo (<1\%); zircão e groutita também podem estar presentes.

As amostras de produtos de beneficiamento apresentaram grande homogeneidade química e mineralógica, com conteúdos de gibbsita superiores a 85\% (quantificados por DRX com o método de Rietveld). As amostras da pesquisa mineral mostraram uma maior variabilidade composicional, compreendendo materiais desde muito ricos em argilominerais (teores de cerca de 70\%) a outros com elevados conteúdos de gibbsita, às vezes da ordem de teores de produtos beneficiados.

Estudos por microscopia eletrônica de varredura (MEV-EDS) permitiram distinguir basicamente duas formas de ocorrência para a gibbsita, mineral de interesse em minérios de bauxita. A primeira forma refere-se a cristais bem definidos com textura límpida e homogênea, isentos de outros elementos químicos em sua estrutura cristalina, enquanto que a segunda está relacionada a uma massa submicrométrica de intercrescimentos entre gibbsita e argilominerais, sendo ainda observados minerais de ferro em meio a esta matriz, também de dimensões submicrométricas.

De maneira geral essas duas formas de ocorrência aparecem intimamente associadas, sendo o contato entre elas, na maioria das vezes, muito tênue e de difícil distinção sob microscopia eletrônica de varredura. Este é um dado relevante tanto ao entendimento dos processos genéticos de formação do minério, quanto ao processo Bayer de produção de alumina, tendo em vista a quantidade de sílica reativa junto ao produto final do beneficiamento, em função dessas associações em escala micrométrica.

Os óxi-hidróxidos de ferro concentram-se como agregados porosos microcristalinos associados ou não a outros minerais, além de estarem também presentes nas massas de composição gibbsita-argilominerais como diminutos 
cristais dispostos aleatoriamente. Além dos minerais hematita e goethita, por espectroscopia Mössbauer foi possível identificar uma fase de $\mathrm{Fe}^{3+}$ de baixa cristalinidade (goethita de baixíssima cristalinidade ou limonita). Juntos, goethita e fase $\mathrm{Fe}^{3+}$, significam mais de $50 \%$ do ferro presente nas amostras.

O recurso estatístico de análise por agrupamento apoiada a difratogramas mostrou-se eficiente para a execução de avaliações preliminares em grande número de amostras de minério de bauxita, associando diferentes populações em grupos de semelhança e retratando não só variações de assembléias mineralógicas como do conteúdo dos minerais presentes.

A utilização da análise por agrupamento facilitou também a aplicação de seqüência específicas de refinamento com o método de Rietveld por difração de raios $X$, adequadas a cada grupo de amostras. Essa facilidade torna as quantificações mais precisas quando se considera a uniformidade da metodologia aplicada a materiais de composição mineralógica similar.

As estratégias de refinamento desenvolvidas possibilitam que um ilimitado número de amostras possa ser classificado em uma análise por agrupamento e, desde que os grupos obtidos coincidam com aqueles previamente identificados, sejam quantificados a partir da estratégia mais adequada a cada um deles.

Em relação às composições mineralógicas das amostras, a DRX com o método de Rietveld apresentou valores satisfatórios de indicadores estatísticos gerados durante os cálculos iterativos (GOF e $R_{w p}$ ), além de elevados coeficientes de correlação linear com as outras metodologias de quantificação aplicadas para os maiores constituintes gibbsita $\left(R^{2}\right.$ igual a 0,984$)$ e argilominerais $\left(R^{2}\right.$ igual a 0,976$)$.

Observou-se ainda boa correlação considerando-se os valores de gibbsita e os teores de alumina aproveitável $\left(R^{2}\right.$ igual a 0,967$)$, assim como os conteúdos de argilominerais e os teores de sílica reativa $\left(R^{2}\right.$ igual a 0,965$)$, dosados pela MRN. Notou-se, porém, maior dispersão de pontos quando correlacionados os conteúdos de argilominerais com os teores dosados de alumina não aproveitável, sugerindo a possibilidade de desvios analíticos para tais análises químicas específicas.

No caso dos óxi-hidróxidos de ferro, uma maior dissimilaridade foi observada entre a DRX-Rietveld e as metodologias de caracterização tradicional e Mössbauer, com valores de correlação linear entre $R^{2}$ de 0,865 e 0,832, respectivamente. 
Presume-se que tal fato esteja relacionado à baixa cristalinidade da goethita e fase $\mathrm{Fe}^{3+}$ que praticamente não foram detectadas por DRX e, portanto, não consideradas na quantificação pelo método de Rietveld. Como conseqüência tem-se, de maneira geral, que os minerais identificados e quantificados por Rietveld estão ligeiramente superestimados (gibbsita e, secundariamente, argilominerais), visto que a análise é normatizada em $100 \%$ para as fases presentes. Tais dissimilaridades também são observadas quando considerados os valores de $\mathrm{Fe}_{2} \mathrm{O}_{3}$ dosados pela MRN.

A ferramenta de DRX com o método de Rietveld foi considerada adequada para a determinação da composição mineralógica de bauxitas, mostrando-se ágil e fornecendo resultados compatíveis com aqueles obtidos por investigações tradicionais de mineralogia para quantificar especificamente gibbsita e argilominerais, apresentando elevadas correlações com os dados de análises químicas, atualmente aplicadas ao controle de mina e do processo $\left(R^{2}>0,96\right)$.

Considera-se, porém, que conteúdos de $\mathrm{Fe}_{2} \mathrm{O}_{3}$ necessitam ser dosados por fluorescência de raios $X(F R X)$ em virtude das características estruturais apresentadas pelos minerais portadores. A mesma abordagem é levantada ao quartzo, que se encontra em proporções inferiores a $2 \%$ nas amostras e próximas ao limite de detecção da técnica de DRX-Rietveld. Para sua estimativa nesta faixa de concentração, sugere-se a difratometria de raios $X$ a partir do levantamento de curvas de calibração e mesmo sua avaliação através da diferença entre determinações de sílica total e reativa, ficando essa última comprometida, dado os elevados desvios analíticos comumente observados em tal técnica analítica.

\subsection{Sugestões de trabalhos complementares}

Como sugestões de trabalhos complementares têm-se:

- ampliar o universo de amostras de bauxita a serem estudadas, explorando uma maior variabilidade em termos de composição mineralógica e, portanto, obtendo dados mais consistentes para avaliações estatísticas;

- validação de dados difratométricos a partir de testes de repetitividade e reprodutibilidade, visando a avaliar os limites e reais possibilidades da técnica; 
- validação de dados de análises químicas a partir de testes de repetitividade e reprodutibilidade, buscando-se avaliar também a consistência e desvios dessa técnica, tradicionalmente aplicada na avaliação de bauxitas. 


\section{REFERÊNCIAS BIBLIOGRÁFICAS}

ALUMÍNIO. Anuário Mineral Brasileiro. Parte III: Estatística por Substâncias, 2006. Disponível em: <www.dnpm.gov.br/assets/galeriaDocumento/AMB2006/III_2006.pdf. Acesso em: agosto 2009.

ALVES, M.E.; MASCARENHAS, Y.P.; VAZ, C.M.P. Comparação de procedimentos de quantificação de caulinita e gibbsita na fração argila desferrificada de latossolos. Revista Brasileira de Ciência do Solo, Viçosa, v. 32, n. 2, p. 569-577, 2008.

ANTONIASSI, J.L. Caracterização mineralógica em bauxitas de Porto Trombetas, PA. 2006. 36 p. Monografia (Trabalho de Formatura) - Instituto de Geociências, Universidade de São Paulo, São Paulo, 2006.

ANTONIASSI, J.L. et al. Caracterização mineralógica em bauxitas de Porto Trombetas, PA. In: ENCONTRO NACIONAL DE TRATAMENTO DE MINÉRIOS E METALURGIA EXTRATIVA, 22., 2007, Ouro Preto, MG. Proceedings. Ouro Preto: UFOP/UFMG/CDTN, 2007. v.1, p. 45-52.

ANTONIASSI, J.L. et al. Análise grupal por difratometria de raios $X$ em apoio à exploração e geometalurgia. In: CONGRESSO BRASILEIRO DE GEOLOGIA, 44., 2008, Curitiba, PR. [Anais]. Curitiba: SBG, 2008. p. 208.

ARNOLD, H.; CHUNG, D.D.L. Review of X-ray diffraction. In: CHUNG, D.D.L. et al. $X$-ray diffraction at elevated temperatures: a method for in-situ process analysis. New York: VCH Publishers, 1992. p. 1-74.

ASSOCIAÇÃO BRASILEIRA DO ALUMÍNIO. São Paulo, 1997. Apresenta objetivos, estrutura organizacional e informações sobre desenvolvimento sustentável e produtos. Disponível em: <www.abal.org.br>. Acesso em: agosto 2009.

AYLMORE, M.G.; WALKER, G.S. The quantification of lateritic bauxite minerals using X-ray powder diffraction by the Rietveld method. Powder Diffraction, Swartmore, v. 13, n. 3, p. 136-143, 1998.

BÁRDOSSY, G.; ALEVA, G.J.J. Lateritic bauxites. Amsterdam: Elsevier, 1990. 624 p. (Developments in economic geology, 27). 
BIONDI, J.C. Sistema mineralizador laterítico. In:

Processos metalogenéticos

e os depósitos minerais brasileiros. São Paulo: Oficina de Textos, 2003. Cap. 6, p. 391-411.

BISH, D.L.; REYNOLDS JR., R. C. Sample preparation for x-ray diffraction. In: BISH, D.L.; POST, J.E. (Ed.). Modern powder diffraction. Washington: Mineralogy Society of America, 1989. p. 73-99. (Reviews in Mineralogy, v. 20).

BLEICHER, L.; SASAKI, J.M. Introdução à difração de raios-X em cristais: Fortaleza: Universidade Federal do Ceará, 2000. 20 p. Apostila de curso.

BOSKI, T.; PAEPE, R. Quantitative mineralogy of bauxites profiles in SE Guinea Bissau. Catena, Braunschweig, v. 15, p. 417-432, 1988.

BOULANGÉ, B.; CARVALHO, A. The bauxite of Porto Trombetas. In: CARVALHO, A. et al. (Ed.). Brazilian bauxites. São Paulo: USP/FAPESP/ORSTOM, 1997. p. 5573.

BÜHMANN, D. An occurrence of authigenic nacrite. Clays and Clay Minerals, Lawrence, v. 36, n. 2, p. 137-140, 1988.

CALTABELOTI, F.P. Estudo comparativo entre métodos de análise quantitativa de fases em clínquer portland: métodos de Bougue, contagem modal e DRXRietveld. 2006. 84 p. Monografia (Trabalho de Formatura) - Instituto de Geociências, Universidade de São Paulo, São Paulo, 2006.

CARVALHO, A.; BOULANGÉ, B.; MELFI, A.J. Alguns aspectos genéticos relacionados aos depósitos de bauxita no Brasil. Boletim IG-USP. Publicação Especial, São Paulo, v. 9, p. 199-121, 1991.

CHAVES, A.P; MASSOLA, C.P. The practice of bauxite ores processing. In: ENCONTRO NACIONAL DE TRATAMENTO DE MINÉRIOS E METALURGIA EXTRATIVA, 22., 2007, Ouro Preto, MG. Proceedings. Ouro Preto: UFOP/UFMG/CDTN, 2007. v.1, p. 187-192.

COMPANHIA DE PESQUISA E RECURSOS MINERAIS. Serviço Geológico do Brasil. Santarém Folha AS.21: Escala 1:1.000.000, 2004. Base de dados Geobank. Disponível em: <http://geobank.sa.cprm.gov.br>. Acesso em: agosto 2009. 
CROMPHAUT, C.V. et al. Characterization by Mössbauer spectroscopy of Fe phases in highly weathered serpentinitic soil from Southern Cameroon. Clay Minerals, London, v. 43, p. 117-128, 2008.

CULLITY, B.D. Elements of X-ray diffraction. 2 ed. Reading: Addison-Wesley, 1978. $555 \mathrm{p}$.

DARDENNE, M.A.; SCHOBBENHAUS, C. The metallogenesis of the South American platform. In: CORDANI, U.G. et al. (Ed.) Tectonic evolution of South America. Rio de Janeiro: [CPRM], 2000. p. 755-850. Publicado durante 031. International Geological Congress, 2000, Rio de Janeiro.

DARDENNE, M.A.; SCHOBBENHAUS, C. Metalogênese do Brasil. Brasília: Editora Universidade de Brasília, 2001. 392 p.

DARDENNE, M.A.; SCHOBBENHAUS, C. Depósitos minerais no tempo geológico e épocas metalogenéticas. In: BIZZI, L.A. et al. (Ed.) Geologia, tectônica e recursos minerais do Brasil: textos, mapas \& SIG. Brasília: CPRM, 2003. p. 365-448.

DAVIS, J.C. Statistics and data analysis in geology. 2 ed. New York: John Wiley, 1986. 646 p.

DIXON, J.B. Kaolinite and serpentine groups minerals. In: MINERALS in soil environments. Madison: Soil Science Society of America, 1977. p. 357-403.

DUTRA, C.V.; GOMES, C.B. A fluorescência de raios X na geologia. In: FORMOSO, M.L.L. et al. Técnicas analíticas instrumentais aplicadas à geologia. São Paulo: Edgar Blücher / Prominério, 1984. p. 84-120.

ELETRONIC statistics textbook. [Tulsa]: StatSoft, Inc., 1984-2008. Disponível em: <www.statsoft.com/textbook/stcluan.html>. Acesso em: agosto 2008.

FERET, F.R.; ROY, D. Determination of quartz in bauxite by a combined X-ray diffraction and X-ray fluorescence method. Spectrochimica Acta. Part B, Oxford, v. 57, n. 3, p. 551-559, 2002.

FLÔRES, J.C.C. Bauxita: características, usos e comparação de metodologias de pesquisa. 1997. 241 p. Dissertação (Mestrado) - Escola Politécnica, Universidade de São Paulo, São Paulo, 1997. 
FORMOSO, M.L.L. Difratometria de raios X. In: FORMOSO, M.L.L. et al. Técnicas analíticas instrumentais aplicadas à geologia. São Paulo: Edgar Blücher / Prominério, 1984. p. 1-43.

FRONZAGLIA, G.C. Análises quantitativas por difração de raios-X em engenharia mineral - aplicação dos métodos de Rietveld e do padrão interno. 1999. 152 p. Dissertação (Mestrado) - Escola Politécnica, Universidade de São Paulo, São Paulo, 1999.

GOBBO, L.A. Os compostos do clínquer Portland: sua caracterização por difração de raios-X e quantificação por refinamento de Rietveld. 2003. 157 p. Dissertação (Mestrado) - Instituto de Geociências, Universidade de São Paulo, São Paulo, 2003.

GOBBO, L.A. Aplicação da difração de raios-X e método de Rietveld no estudo de cimento Portland. 2009. 251 p. Tese (Doutorado) - Instituto de Geociências, Universidade de São Paulo, São Paulo, 2009.

GOLDSTEIN, J.I. et al. Scanning electron microscopy and x-ray microanalysis: a text for biologists, materials scientists, and geologists. 2 ed. New York: Plenum Press, 2003. 689 p.

HERNALSTEENS, C.M.O.; LAPA, R.P. Bauxita de Porto Trombetas, Oriximiná, Pará. In: SCHOBBENHAUS, C.; COELHO, C.E.S. (Coord.) Principais depósitos minerais do Brasil. Brasília: Departamento Nacional da Produção Mineral, 1988. v. 2, p. 599-639.

HILL, V.G.; SEHNKE, E.D. Bauxite. In: KOGEL, J.E. et al. (Ed.) Industrial minerals and rocks: commodities, markets and uses. 7 ed. Littleton: Society for Mining, Metallurgy and Exploration, 2006. p. 227-261.

HORBE, A.M.C. et al. A laterização na gênese das superfícies de aplanamento da região de Presidente Figueiredo - Balbina, nordeste do Amazonas. In: REIS, N.A.; MONTEIRO, M.A.S. (Coord.) Contribuições à geologia da Amazônia. Manaus: SBG-NO, 2001. v. 2, p. 145-176.

INTERNATIONAL CENTRE FOR DIFFRACTION DATA. Apresenta informações sobre missão, pesquisas, produtos desenvolvidos, etc. Disponível em: <www.icdd.com>. Acesso em: agosto 2009.

ISOITKO, V.M. Statistical methods in technological mineralogy. In: SYMPOSIUM ON PROCESS MINERALOGY, 9, Las Vegas, 1989. Process mineralogy IX: 
applications to mineral beneficiation, metallurgy, gold, diamonds, ceramics, environment and health: proceedings. Warrendale: Tms, 1990. p. 201-204.

JENKINS, R. X-ray fluorescence spectrometry. New York: John Wiley, 1988. 175 p. (Chemical analysis, v. 99).

JENKINS, R. Instrumentation. In: BISH, D.L.; POST, J.E. (Ed.). Modern powder diffraction. Washington: Mineralogy Society of America, 1989. p. 19-43. (Reviews in Mineralogy, v. 20).

JENKINS, R.; SNYDER, R.L. Introduction to x-ray powder diffractometry. New York: John Wiley, 1996. 403 p.. (Chemical Analysis, v. 138).

JONES, M.P. Applied mineralogy: a quantitative approach. London: Graham \& Trotman, 1987. 259 p.

JORGE, F.O. Caracterização de sedimentos marinhos do Rio Casqueiro, Cubatão, São Paulo, por espectroscopia Mössbauer, PIXE e susceptibilidade magnética: um estudo de magnetismo ambiental. 2005. 98 p. Dissertação (Mestrado) - Instituto de Física, Universidade de São Paulo, São Paulo, 2005.

KIRWAN, L.J. et al. Characterisation of various Jamaican bauxite ores by quantitative Rietveld x-ray powder diffraction and 57Fe Mössbauer spectroscopy. International Journal of Mineral Processing, Amsterdam, v. 91, n. 1-2, p. 14-18, 2009.

KLUG, H.P.; ALEXANDER, L.E. X-ray diffraction procedures for polycrystalline and amorphous materials. 2 ed. New York: John Wiley, 1974. 996 p.

KOTSCHOUBEY, B. et al. Caracterização e gênese dos depósitos de bauxita da província bauxitífera de Paragoninas, noroeste da Bacia do Grajaú, noroeste do Pará / oeste do Maranhão. In: CARACTERIZAÇÃO em depósitos minerais em distritos mineiros da Amazônia. Brasília: DNPM / CT/MINERAL / ADIMB, 2005. p. 691-776.

LI, D. et al. Mineralogy of Al-substituted goethites. Powder Diffraction, Swartmore, v. 21, n. 4 , p. 289-299, 2006.

MANLY, B.F.J. Cluster Analysis. In: London: Chapman, 1994. Cap. 9, p. 129-145.

Multivariate statistical methods. 2 ed. 
MASSOLA, C.P. Flotação reversa da bauxita de Mirai, MG. 2008. 85 p. Dissertação (Mestrado) - Escola Politécnica, Universidade de São Paulo, São Paulo, 2008.

MCCUSKER, L.B. et al. Rietveld refinement guidelines. Journal of Applied Crystallography, Copenhagen, v. 32, p. 36-50, 1999.

MELFI, A.J. Brazilian bauxite deposits: a review. In: CARVALHO, A. et al. (Ed.) Brazilian bauxites. São Paulo: USP/FAPESP/ORSTOM, 1997. p. 3-22.

MINERAÇÃO RIO DO NORTE. Apresenta informações sobre operações com bauxita na região Amazônica. Disponível em: <www.mrn.com.br>. Acesso em: agosto 2009.

MURAD, E. Characterization of a standard bauxite and its deferration products by Mössbauer spectroscopy. Minerals Engineering, Oxford, v. 18, p. 984-986, 2004.

NONG, L. et al. Qualitative and quantitative phase analyses of Pingguo bauxite mineral using x-ray powder diffraction and the Rietveld method. Powder Diffraction, Swartmore, v. 22, n. 4, p. 300-302, 2007.

PAIVA-SANTOS, C.O. Aplicações do método de Rietveld. Araraquara: LabCACC Instituto de Química/UNESP, 1989. Material de Curso à Distância.

PAIVA-SANTOS, C.O.; ANTONIO, S.G. Caracterização de materiais pelo método de Rietveld com dados de difração por policristais. Araraquara: LabCACC Instituto de Química/UNESP, 2003. Material de Curso à Distância.

PEIXOTO, S.F.; HORBE, A.M.C. Bauxitas do nordeste do Amazonas. Revista Brasileira de Geociências, São Paulo, v. 38, n. 2, p. 406-422, 2008.

POST, J.E.; BISH, D.L. Rietveld refinement of crystal structures using powder x-ray diffraction data. In: BISH, D.L.; POST, J.E. (Ed.). Modern powder diffraction. Washington: Mineralogy Society of America, 1989. p. 277-308. (Reviews in Mineralogy, v. 20).

RAJ, D.; HARCHAND, K.S.; MAINI, V. Characterization of iron minerals in bauxite. Nuclear Instruments and Methods in Physics Research, B76. Holanda: Elsevier Science Publishers B.V., 1993. p. 242-243. 
RATTI, G. Análises químicas na engenharia mineral. 1994. 83 p. Tese (Doutorado) - Escola Politécnica, Universidade de São Paulo, São Paulo, 1994.

RESENDE, M.; BAHIA FILHO, A.F.C.; BRAGA, J.M. Mineralogia da argila de latossolos estimada por alocação a partir do teor total de óxidos do ataque sulfúrico. Revista Brasileira de Ciência do Solo, Campinas, v. 11, p. 17-23, 1987.

REYNOLDS JR., R.C. Principles of powder diffraction. In: BISH, D.L.; POST, J.E. (Ed.). Modern powder diffraction. Washington: Mineralogy Society of America, 1989. p. 1-17. (Reviews in Mineralogy, v. 20).

RIETVELD, H. M. A profile refinement method for nuclear and magnetic structures. Journal of Applied Crystallography, Copenhagen, v. 2, p. 65-71, 1969.

SAMPAIO, J.A.; ANDRADE, M.C.; DUTRA, A.J.B. Bauxitas. In: LUZ, A.B.; LINS, F.A.F. (Ed.) Rochas \& minerais industriais: usos e especificações. Rio de Janeiro: CETEM/MCT, 2005. p.279-303.

SANT'AGOSTINO, L.M. Caracterização tecnológica de um depósito mineral um estudo de caso: o nióbio de Catalão I, Goiás. 1996. 200 p. Tese (Doutorado) Escola Politécnica, Universidade de São Paulo, São Paulo, 1996.

SANT'AGOSTINO, L.M.; GOBBO, L.A.; BRUMATTI, M. A difração de raios x e método de Rietveld aplicados a estudos de bauxita. In: ENCONTRO NACIONAL DE TRATAMENTO DE MINÉRIOS E METALURGIA EXTRATIVA, 21., 2005, Natal, RN. Anais. Natal: UFRN-CEFET/RN, 2005. v. 1, p. 85-92.

SANTOS, A.C.F.; COSTA, M.L.; SCHUCKMANN, W.K. Quantificação mineralógica e grau de substituição isomórfica Fe-Al na hematita e goethita de bauxitas da Amazônia oriental combinando DRX e FRX. Geociências, São Paulo, v. 16, p. 109124, 1997.

SPICER, E.; VERRYN, S.M.; DEYSEL, K. Analysis of heavy mineral sands by quantitative $\mathrm{x}$-ray powder diffraction and mineral liberation analyser - implications for process control. In: INTERNATIONAL CONGRESS FOR APPLIED MINERALOGY, $9^{\text {th }}, 2008$, Brisbane, Austrália. ICAM 2008: proceedings. Victoria: The Australasian Institute of Mining and Metallurgy, 2008. p. 166-172.

TAN, P.; STEINBACH, M.; KUMAR, V. Cluster Analysis: Basic Concepts and Algorithms. In: Introduction to data mining. Boston: Pearson Addison Wesley, 2005. Cap. 8, p. 487-568. 
TOLEDO, M.C.M. Evolução geoquímica, mineralógica e micromorfológica no processo de bauxitização: estudo comparativo dos despósitos de Mogi das Cruzes, Curucutu e Lavrinhas, SP, associados a diferentes tipos litológicos. 1981. 106 p. Dissertação (Mestrado) - Instituto de Geociências, Universidade de São Paulo, São Paulo, 1981.

TOLEDO, M.C.M; OLIVEIRA, S.M.B.; MELFI, A.J. Intemperismo e formação do solo. In: TEIXEIRA, W. et al. Decifrando a terra. São Paulo: Oficina de Textos, 2000. p. 139-166.

TROMBETAS. Hidrografia do Complexo da Região Hidrográfica do Amazonas, a maior bacia hidrográfica do mundo. 2009. Disponível em: <http://pt.wikipedia.org/wiki/Rio_trombetas >. Data de acesso: setembro 2009.

TRUCKENBRODT, W.; KOTSCHOUBEY, B.; SCHELLMANN, W. Composition and origin of the clay cover on north brazilian laterites. Geologische Rundschau, Berlin, v. 80 , n. 3, p. 591-610, 1991.

ULSEN, C. et al. Redução do teor de sílica livre em minério de bauxita através da otimização da britagem. In: ENCONTRO NACIONAL DE TRATAMENTO DE MINÉRIOS E METALURGIA EXTRATIVA, 22., 2007, Ouro Preto, MG. Proceedings. Ouro Preto: UFOP/UFMG/CDTN, 2007. v. 2, p. 557-565.

VALE. Alumínio. Disponível em: <www.vale.com>. Data de acesso: agosto 2009.

X'PERT Data Collection Software. Version 2.2c. Release 14-Aug-2007. [Almelo]: PANalytical, 2007 (Licensed modules PW3240). 1CD-ROM.

X'PERT High Score Plus Software. Version: 2.2d. Release 05-Sep-2008. [Almelo]: PANalytical, 2008 (Licensed modules PW3212). 1CD-ROM.

WERTHEIEM, G.K. Mössbauer effect: principles and applications. New York: Academic Press, 1964. 116 p.

WILL, G. Powder diffraction: the Rietveld method and two stage method to determine and refine crystal structures from powder diffraction data. Berlin: Springer, 2006. 224 p.

YOUNG, R.A. The Rietveld method. Oxford: Oxford University Press, 2002. (International Union of Crystallography Monographs on Crystallography, 5). 


\section{APÊNDICE A}

Ajustes dos espectros obtidos por espectroscopia Mössbauer 
Apêndice A

Ajustes dos espectros obtidos por espectroscopia Mössbauer

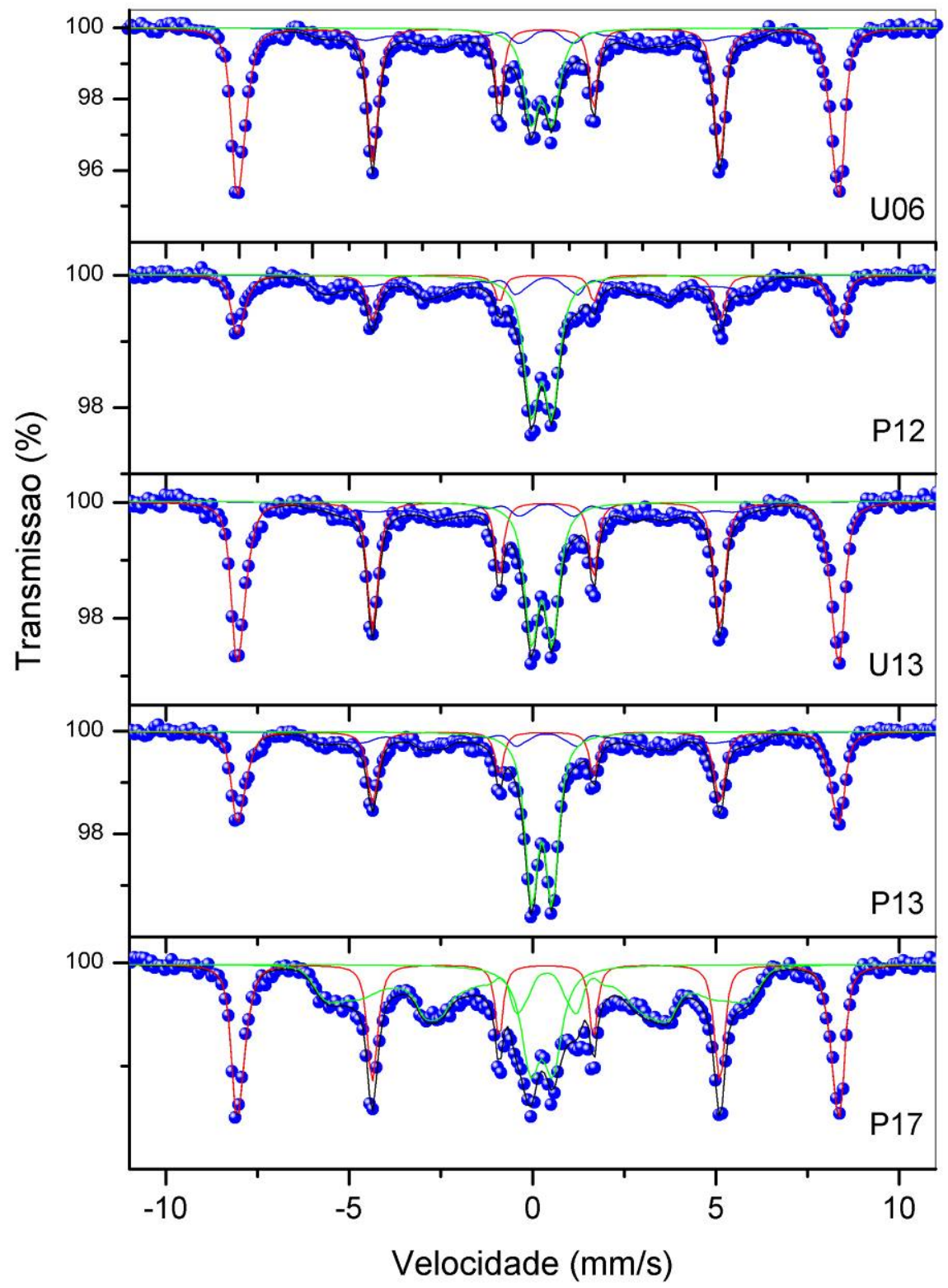

Figura 51 - Ajustes dos espectros Mössbauer obtidos das amostras U06, P12, U13, P13, P17 
Apêndice A

Ajustes dos espectros obtidos por espectroscopia Mössbauer

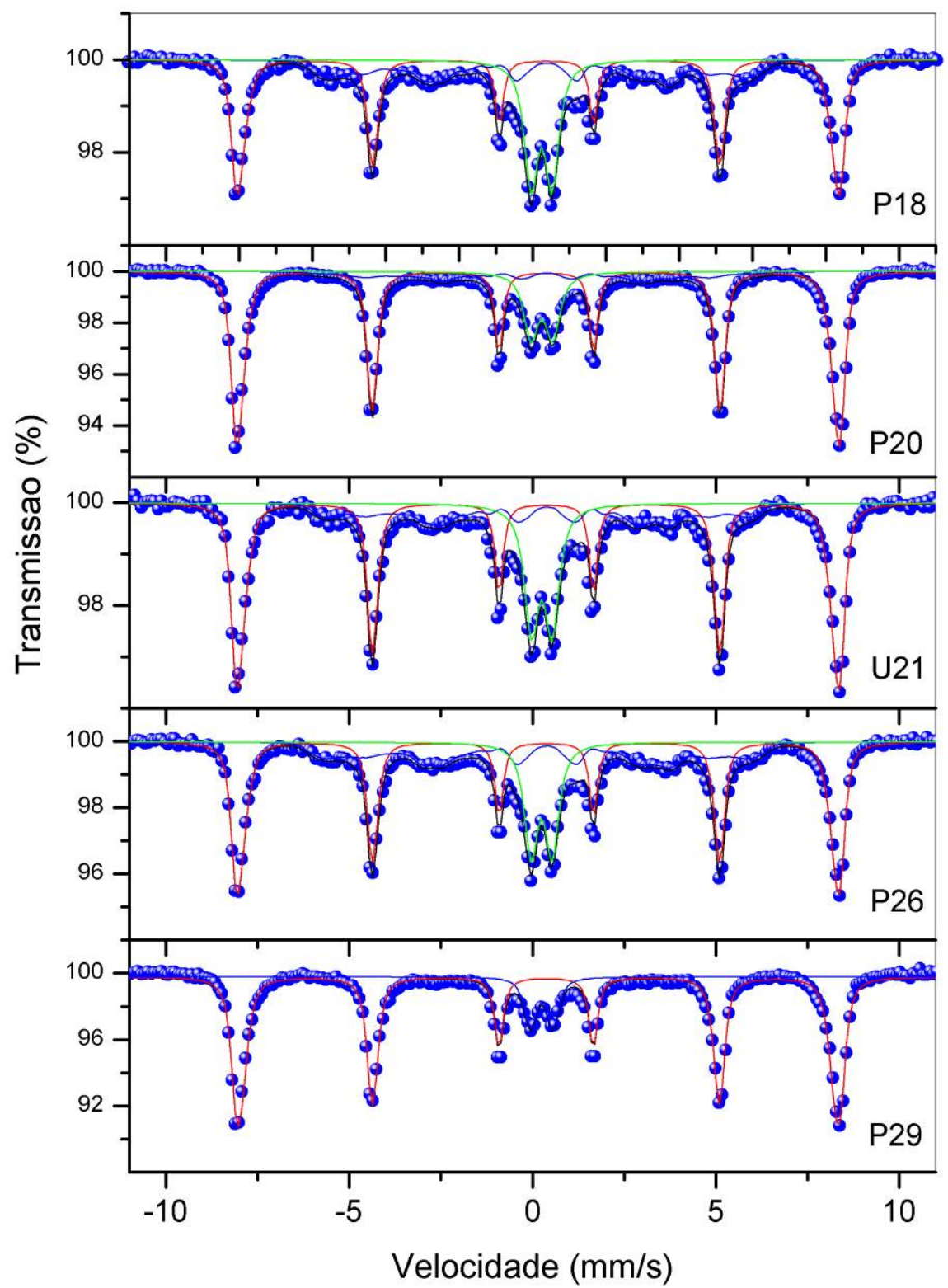

Figura 52 - Ajustes dos espectros Mössbauer obtidos das amostras P18, P20, U21, P26, P29 


\section{APÊNDICE B}

Ajustes dos refinamentos pelo método de Rietveld 


\section{Apêndice B}

Ajustes dos refinamentos pelo método de Rietveld

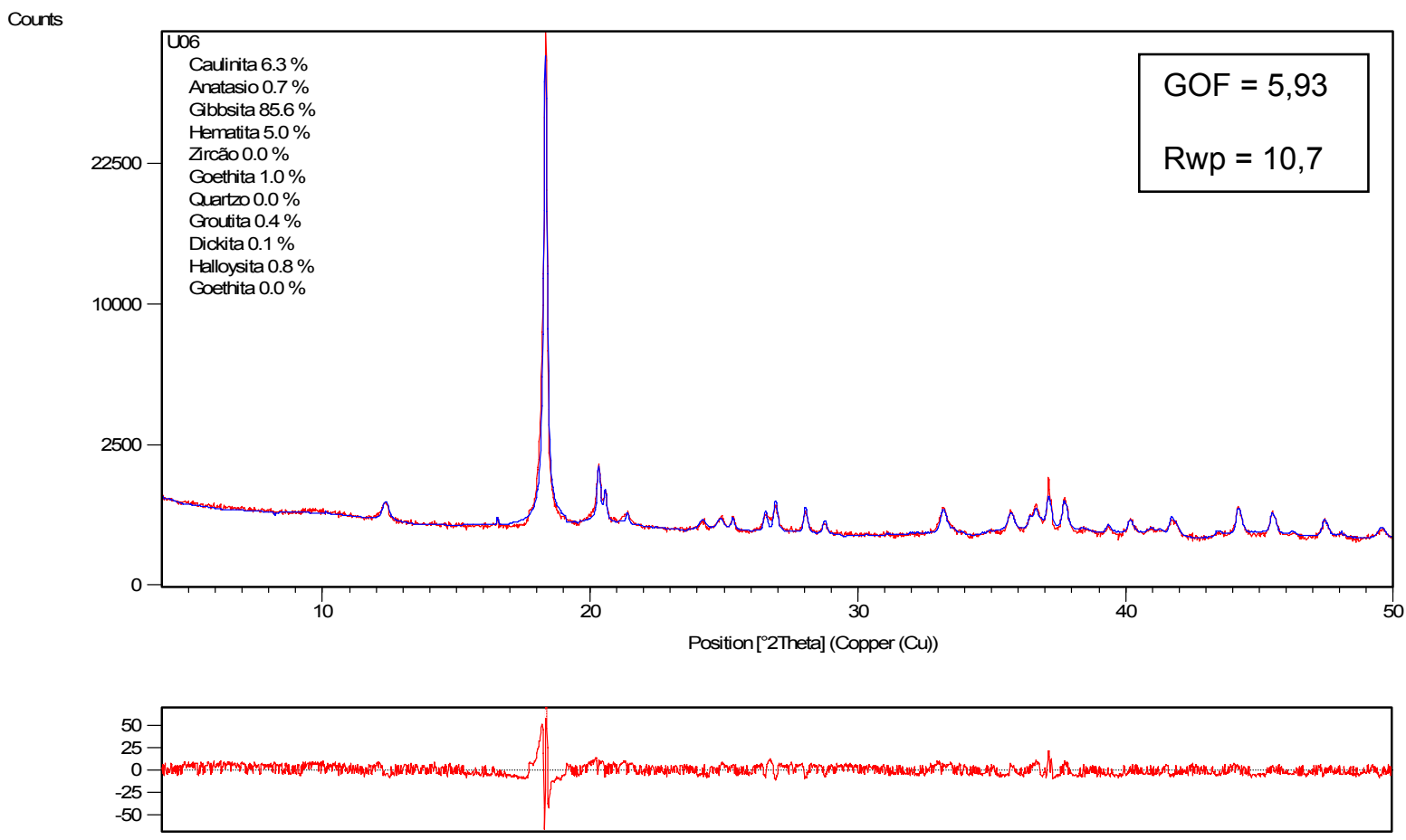

Figura 53 - Difratograma da amostra U06 refinado pelo método de Rietveld

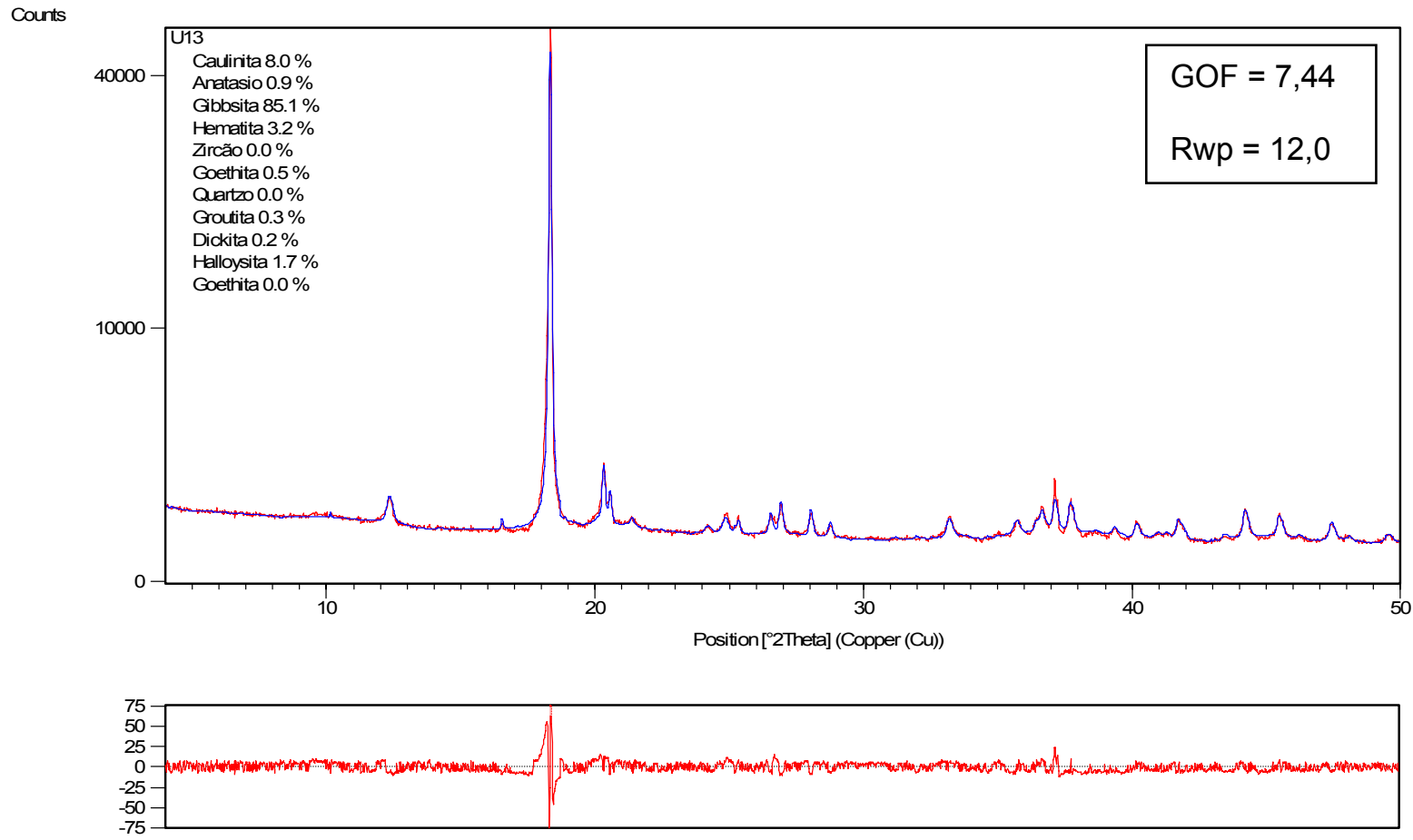

Figura 54 - Difratograma da amostra U13 refinado pelo método de Rietveld 


\section{Apêndice B}

Ajustes dos refinamentos pelo método de Rietveld
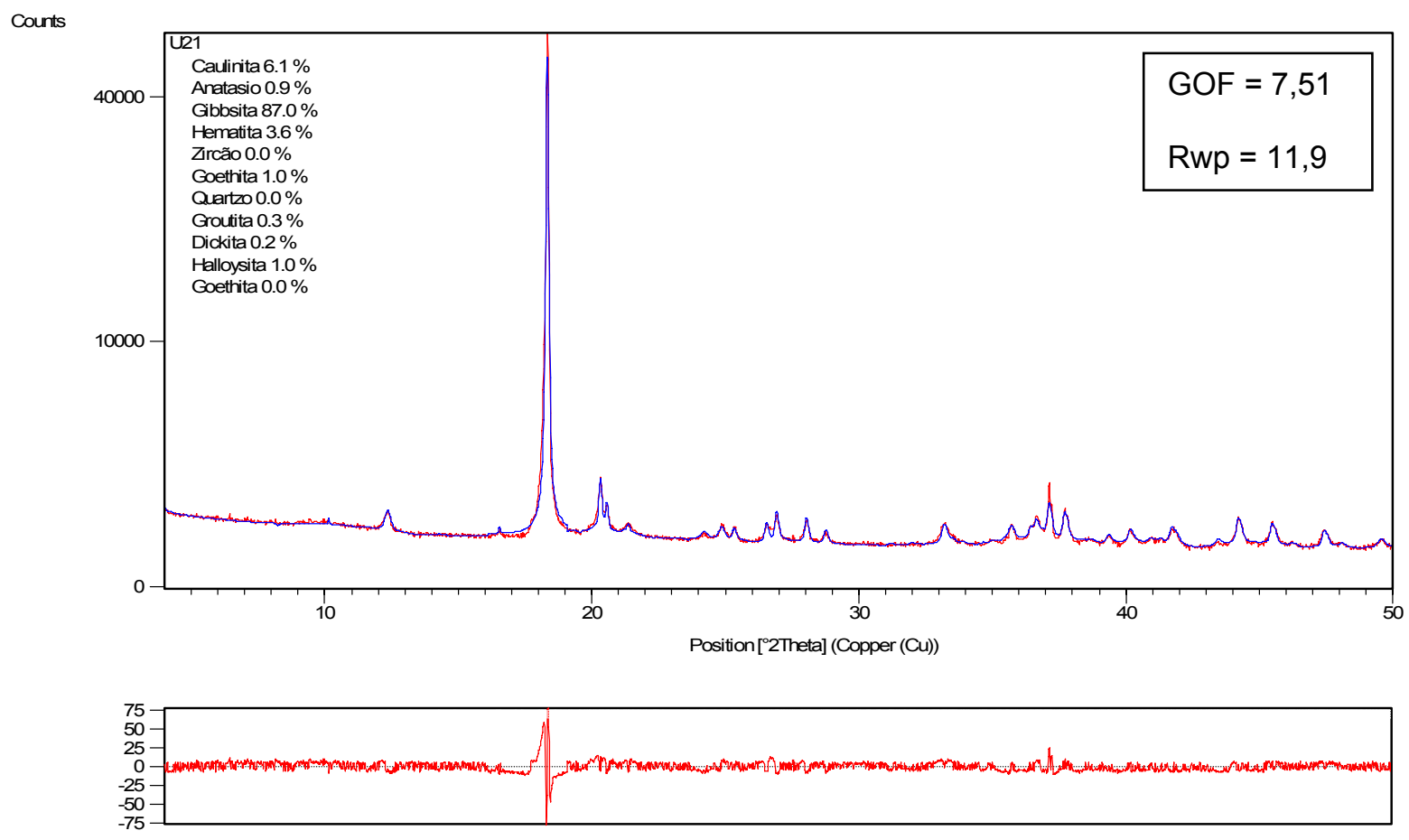

Figura 55 - Difratograma da amostra U21 refinado pelo método de Rietveld

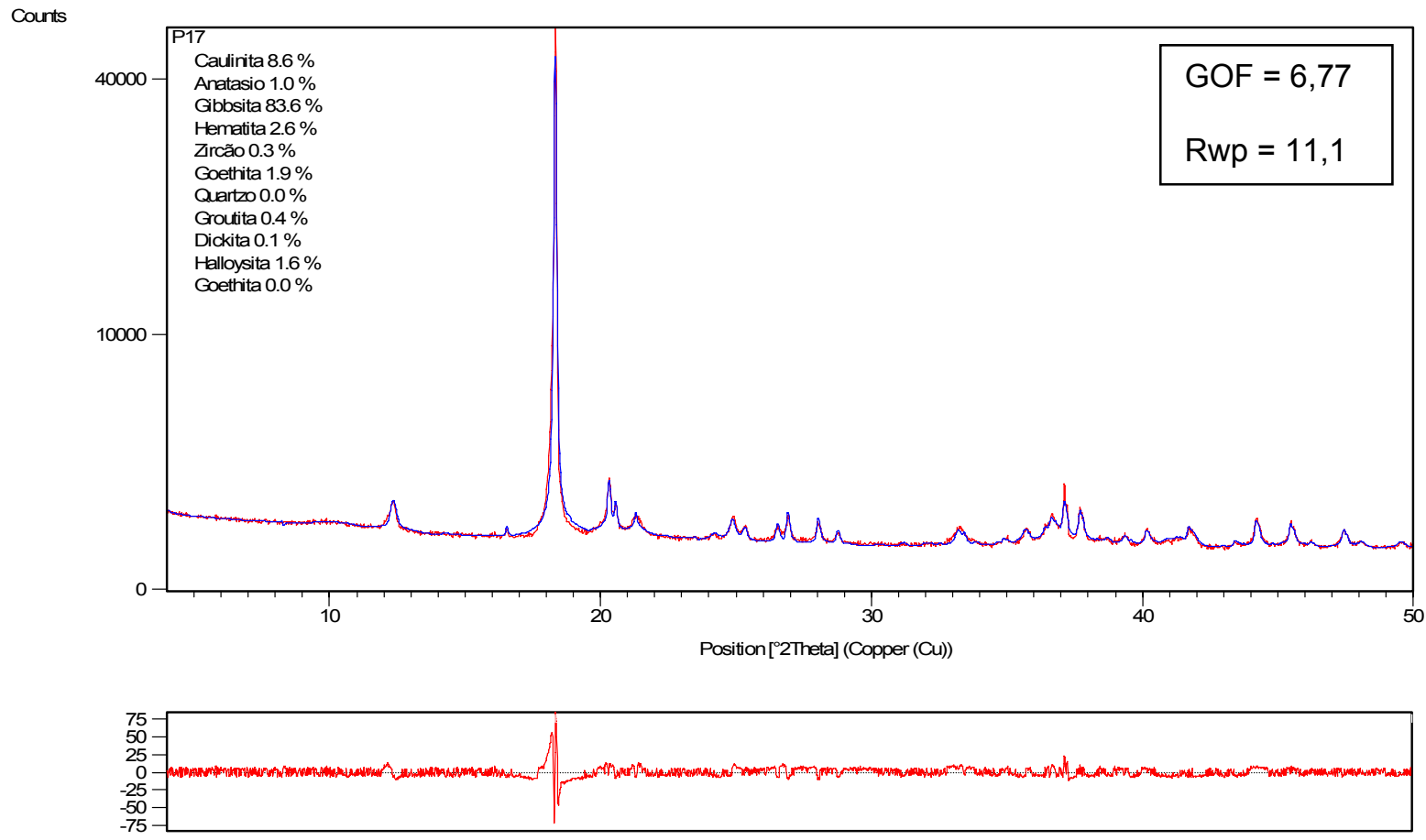

Figura 56 - Difratograma da amostra P17 refinado pelo método de Rietveld 


\section{Apêndice B}

Ajustes dos refinamentos pelo método de Rietveld

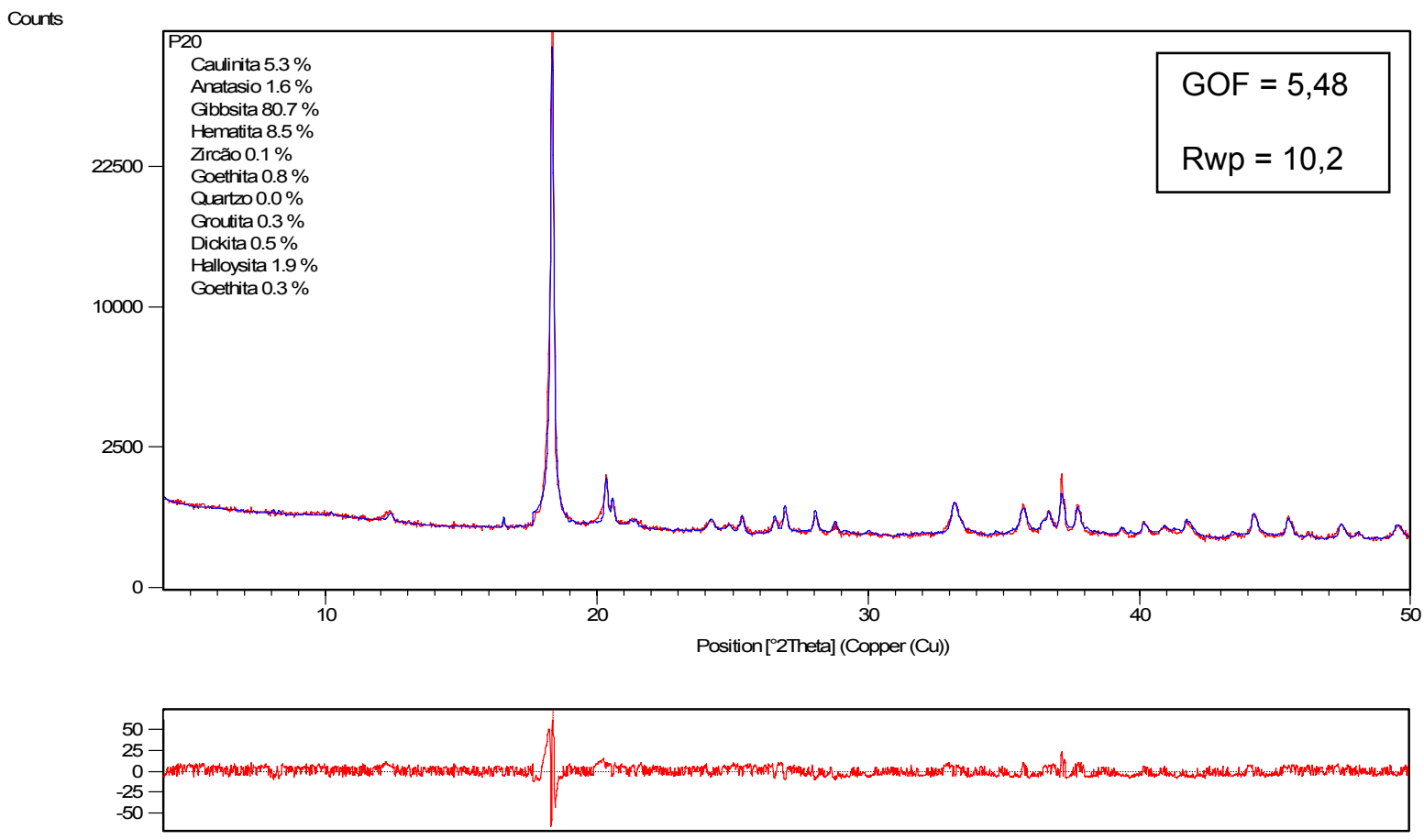

Figura 57 - Difratograma da amostra P20 refinado pelo método de Rietveld
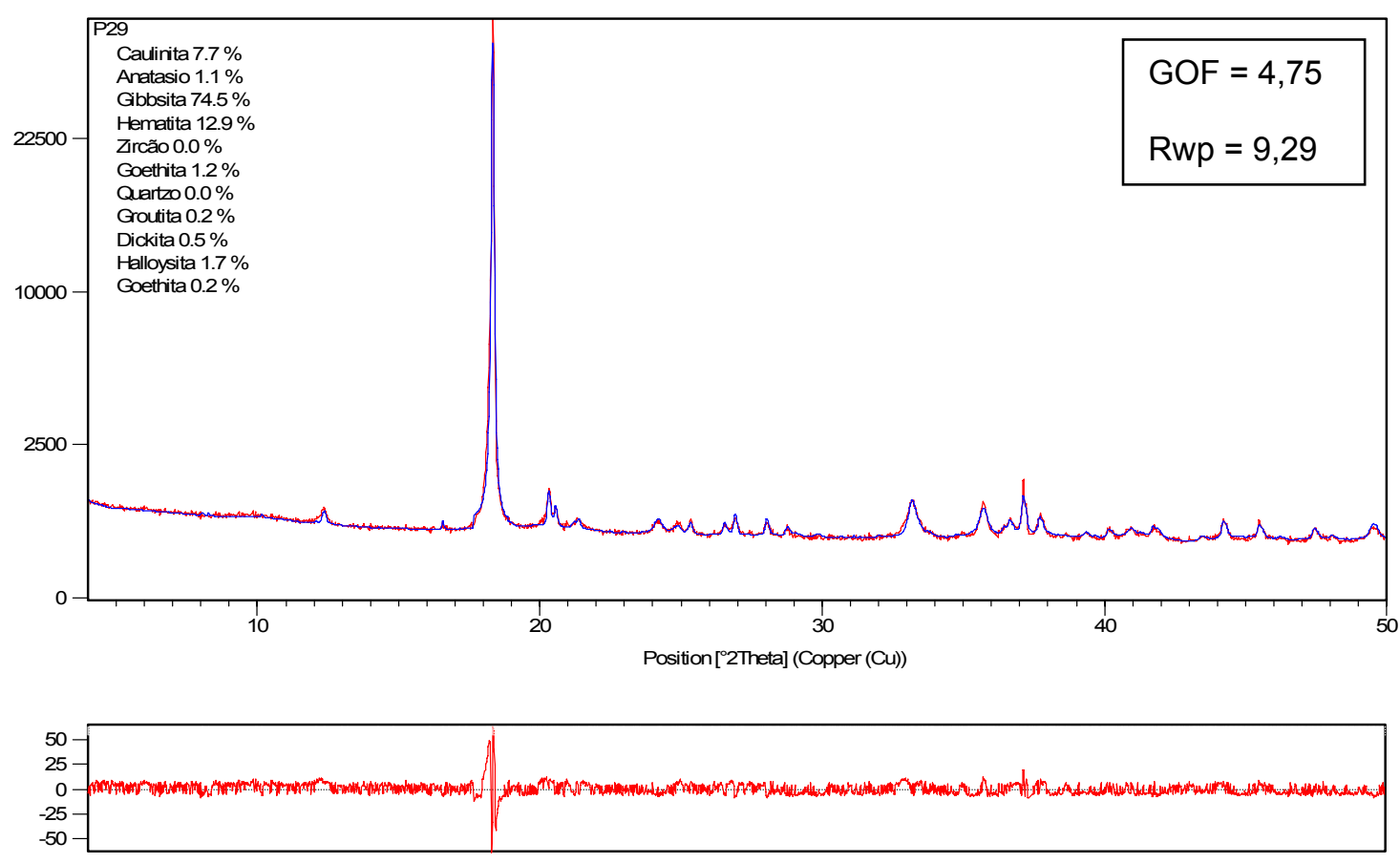

Figura 58 - Difratograma da amostra P29 refinado pelo método de Rietveld 


\section{Apêndice B}

Ajustes dos refinamentos pelo método de Rietveld

Counts
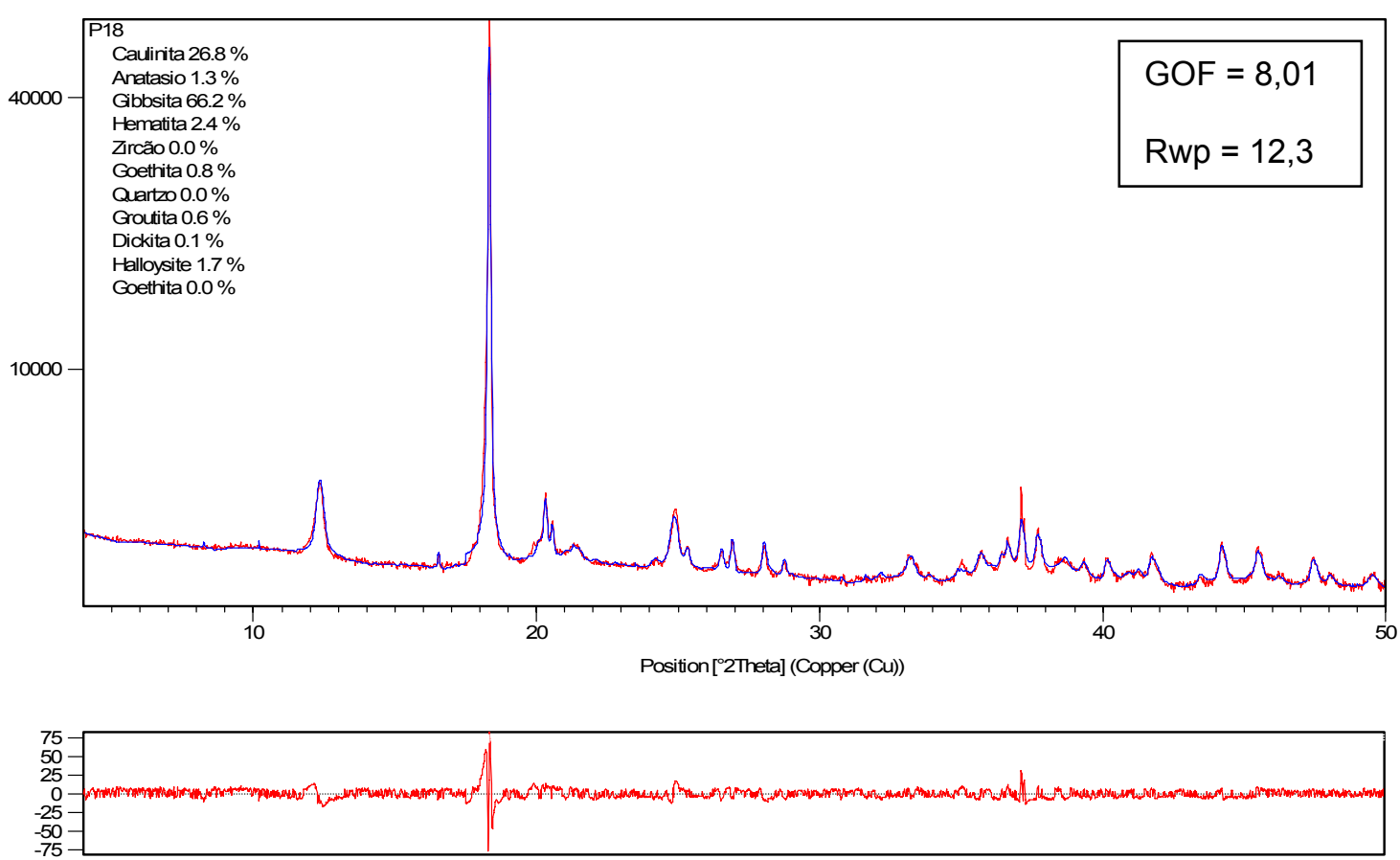

Figura 59 - Difratograma da amostra P18 refinado pelo método de Rietveld
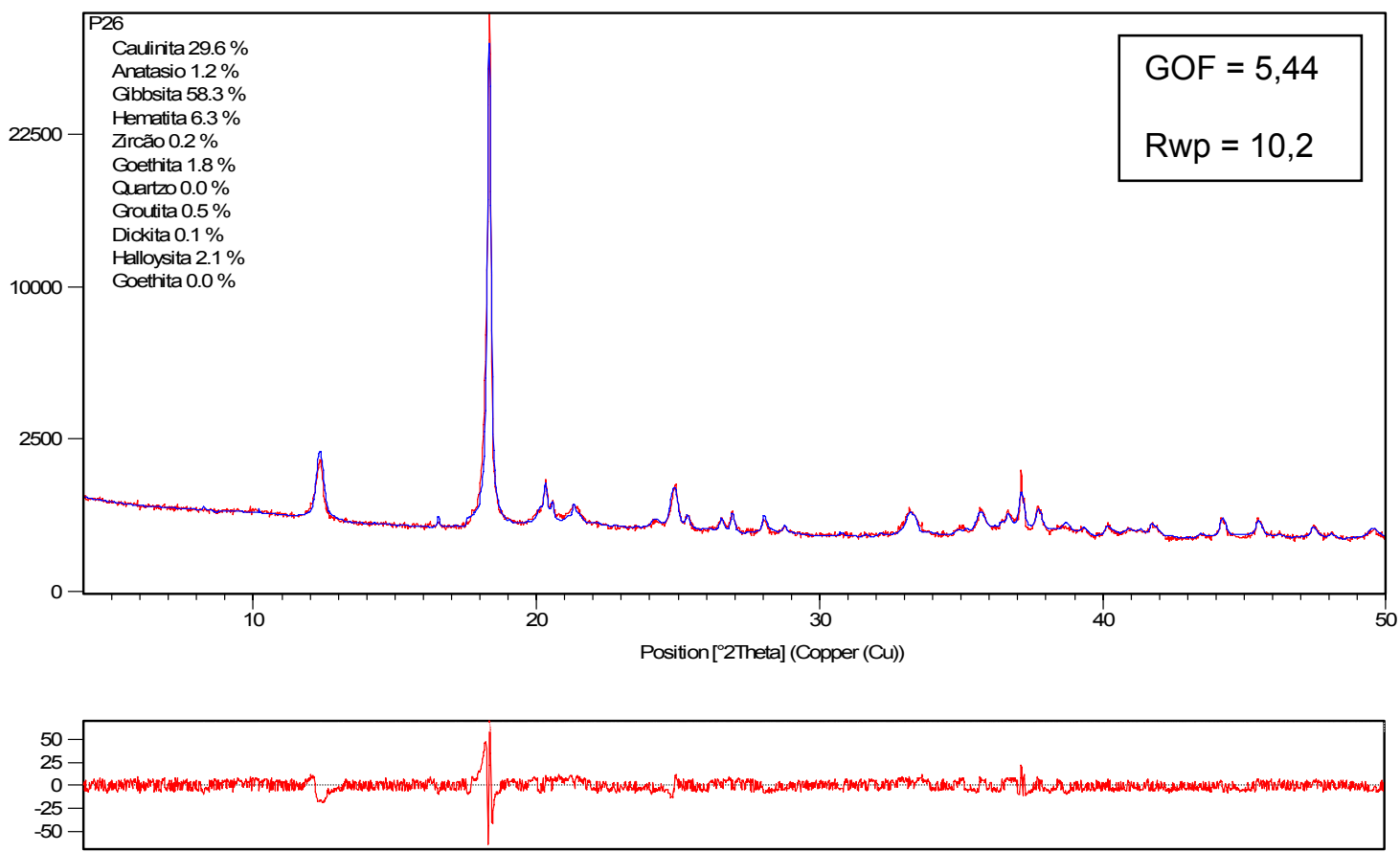

Figura 60 - Difratograma da amostra P26 refinado pelo método de Rietveld 


\section{Apêndice B}

Ajustes dos refinamentos pelo método de Rietveld
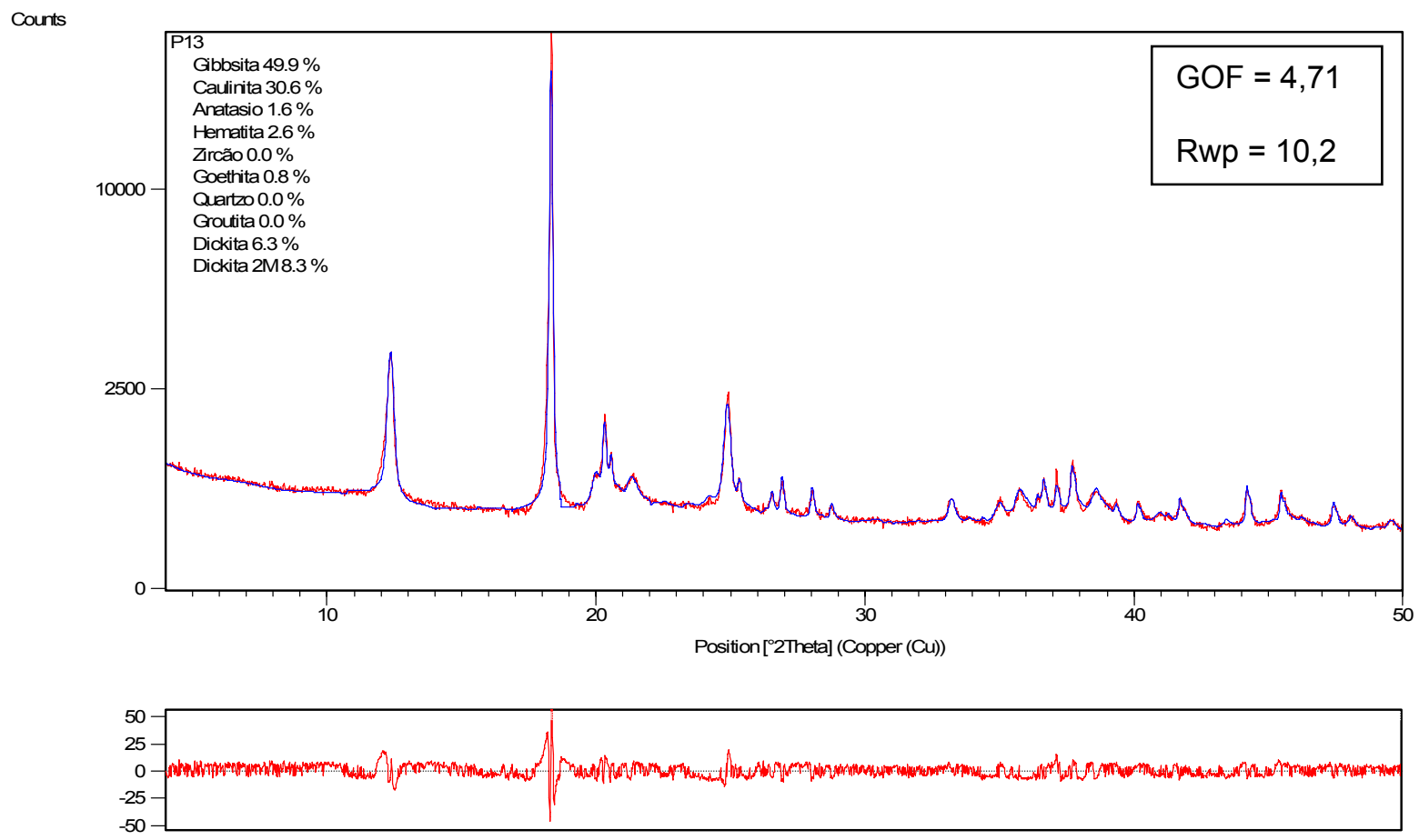

Figura 61 - Difratograma da amostra P13 refinado pelo método de Rietveld

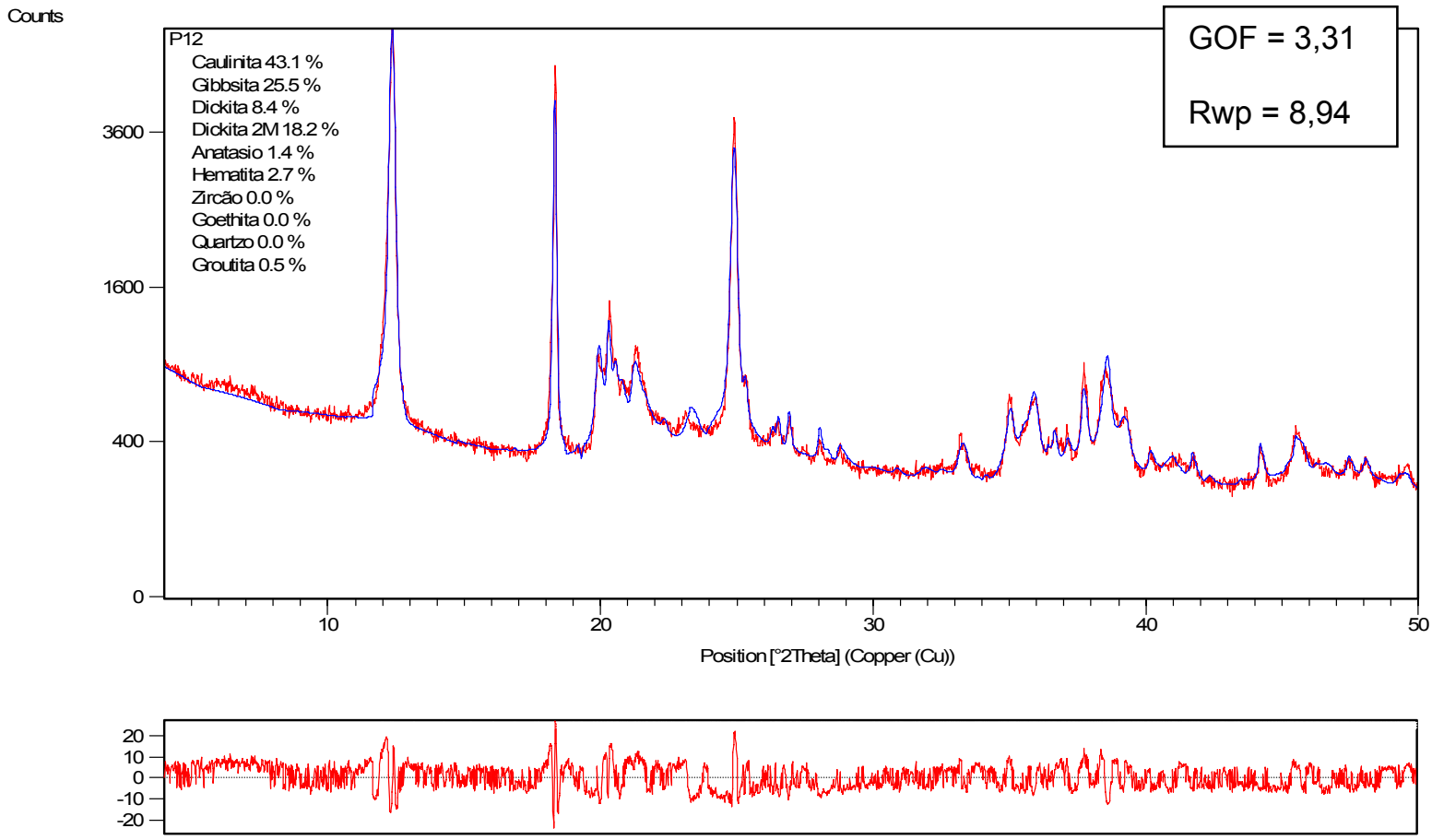

Figura 62 - Difratograma da amostra P12 refinado pelo método de Rietveld 